$$
\begin{gathered}
\text { (director/diretor) } \\
\text { Castañeda Zumeta } \\
\text { (editor) } \\
\text { Prólogo/Prefácio: } \\
\text { José Luis Valero Sancho }
\end{gathered}
$$

\title{
Nuevas narrativas visuales Novas narrativas visuais
}

Cuadernos Artesanos de Comunicación / 150

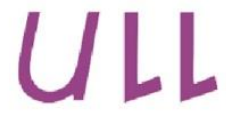

Universidad de La Laguna

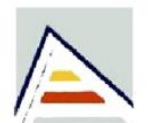

Universitat d'Alacant Universidad de Alicante

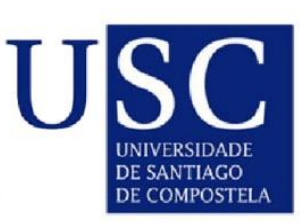

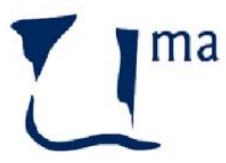

UNIVERSIDAD $D E M \dot{A} L A G A$

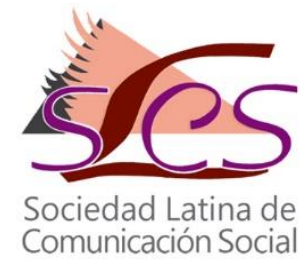




\section{Cuadernos Artesanos de Comunicación}

Coordinador editorial: José Manuel de Pablos - jpablos@,ull.edu.es

Comité Científico

Presidencia: José Luis Piñuel Raigada (UCM)

Secretaría: Milena Trenta (ULL)

- Ramón Zallo (Universidad del País Vasco, UPV-EHU)

- Núria Almiron (Universidad Pompeu Fabra, UPF)

- Francisco Campos Freire (Unioversidad de Santoiago de Compostela)

- José Cisneros (Benemérita Universidad Autónoma de Puebla, BUAP)

- Bernardo Díaz Nosty (Universidad de Málaga, UMA)

- Carlos Elías (Universidad Carlos III de Madrid, UC3M)

- Paulina B. Emanuelli (Universidad Nacional de Córdoba, UNC)

- José Luis González Esteban (Universitas Miguel Hernández de Elche, UMH)

- Marisa Humanes (Universidad Rey Juan Carlos, URJC)

- Juan José Igartua (Universidad de Salamanca, USAL)

- Xosé López (Universidad de Santiago de Compostela)

- Maricela López-Ornelas (Universidad Autónoma de Baja California, AUBC)

- Javier Marzal (Universidad Jaume I, UJI)

- José Antonio Meyer (Benemérita Universidad Autónoma de Puebla, BUAP)

- Ramón Reig (Universidad de Sevilla, US)

- Miquel Rodrigo Alsina (Universidad Pompeu Fabra, UPF)

- Xosé Soengas (Universidad de Santiago de Compostela)

- José Luis Terrón (Universidad Autónoma de Barcelona, UAB)

- José Miguel Túñez (Universidad de Santiago, USC)

- Victoria Tur (Universidad de Alicante, UA)

- Miguel Vicente (Universidad de Valladolid, UVA)

* Queda expresamente autorizada la reproducción total o parcial de los textos publicados en este libro, en cualquier formato o soporte imaginables, salvo por explícita voluntad en contra del autor o autora o en caso de ediciones con ánimo de lucro. Las publicaciones donde se incluyan textos de esta publicación serán ediciones no comerciales y han de estar igualmente acogidas a Creative Commons. Harán constar esta licencia y el carácter no venal de la publicación.

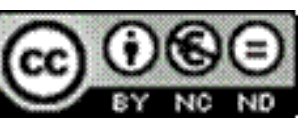

Este libro y cada uno de los capítulos que contiene (en su caso), así como las imágenes incluidas, si no se indica lo contrario, se encuentran bajo una Licencia Creative Commons Atribución-No Comercial-Sin Derivadas 3.0 Unported. Puede ver una copia de esta licencia en http://creativecommons.org/licenses/by-nc-nd/3.0. Esto significa que Ud. es libre de reproducir y distribuir esta obra, siempre que cite la autoría, que no se use con fines comerciales o lucrativos y que no haga ninguna obra derivada. Si quiere hacer alguna de las cosas que aparecen como no permitidas, contacte con los coordinadores del libro o con el autor del capítulo correspondiente.

* La responsabilidad de cada texto es de su autor o autora. 


$$
\begin{gathered}
\text { José Luis } \\
\text { Valero Sancho } \\
\text { (director/diretor) }
\end{gathered}
$$

\author{
Aitor \\ Castañeda Zumeta \\ (editor) \\ José Luis Valero Sancho \\ Prólogo/Prefácio:
}

\title{
Nuevas narrativas visuales Novas narrativas visuais
}

Cuadernos Artesanos de Comunicación / 150

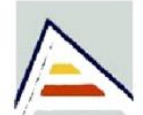

Universitat d'Alacant Universidad de Alicante
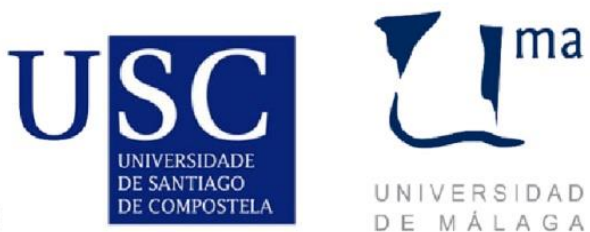

UNIVERSIDAD DE MÁLGA

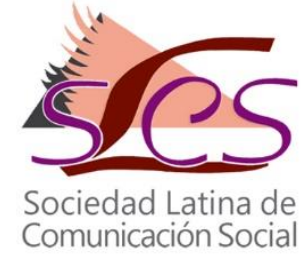


CAC $150^{\circ}$ - Nuevas narrativas visuales / Novas narrativas visuais

José Luis Valero Sancho (dir.), Aitor Castañeda Zumeta (coord.) |

Precio social: $10,15 € \mid$ Precio en librería. 13,20€

Editores: Javier Herrero y Milena Trenta

Diseño: F. Drago

Ilustración de portada: Jordi Català Domínguez

Imprime y distribuye: F. Drago. Andocopias S. L.

C/ La Hornera, 41. La Laguna. Tenerife.

Teléfono: 922250554 | fotocopiasdrago@telefonica.net

Edita: Sociedad Latina de Comunicación Social - edición no venal

- La Laguna (Tenerife), 2018 - Creative Commons

http://www.revistalatinacs.org/14SLCS/portada2014.html

Descargar en pdf:

http://www.cuadernosartesanos.org/\#150

Protocolo de envío de manuscritos con destino a CAC: (la colección que corresponda)

http://www.cuadernosartesanos.org/protocolo.html

ISBN - 13: 978-84-17314-05-7

DL: TF-1014-2018

DOI: $\underline{10.4185 / \operatorname{cac} 150}$ 


\section{Índice}

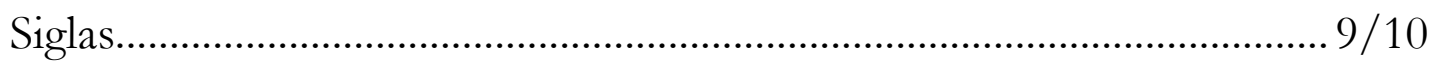

Nuevas narrativas visuales. Prólogo ................................................................... 11

Novas narrativas visuais. Prefácio ...................................................................... 15

I. La infografía contra el terrorismo.................................................................. 19

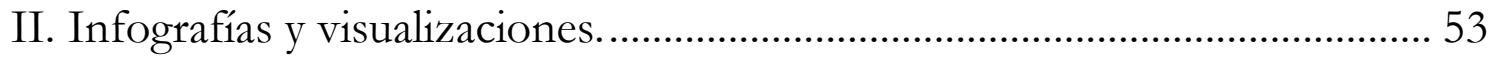

II. Infografía periodística o visualización de datos en clave de semiología ..... 79

IV. La infografía: un lenguaje multimedia adecuado a las nuevas narrativas 111

V. Infografía: cambio de escenario ...................................................................... 137

VI. Aproximación a una taxonomía de la visualización de datos ..................... 165

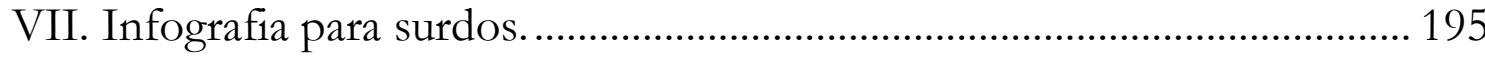

VIII. Hiperinfografia: onde está a visualização sintética no jornalismo de nova

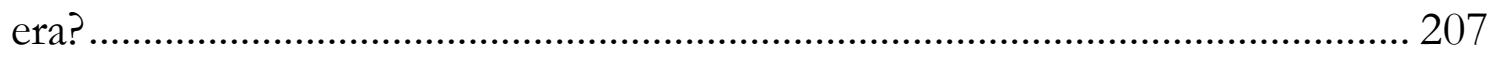

IX. La infografía didáctica en el OCW de la Universidad del País

Vasco (2013-2018) ....................................................................................... 227

Los autores del libro ................................................................................... 227

\section{El contenido de este libro ha sido sometido a un proceso de revisión de doble ciego por pares, semejante al sistema de revisión de un artículo científico para un journal.}


José Luis Valero Sancho (director)

Aitor Castañeda Zumeta (editor)

Prólogo: José Luis Valero Sancho

\title{
Nuevas narrativas visuales
}

Autores: Aitor Castañeda, Jordi Català, Hernán Franco, Mariana Lapolli, Beatriz Elena Marín-Ochoa, Federico Medina, Francesc Morera, William Robson, José Luis Valero, Tarcísio Vanzin.

\begin{abstract}
Cuando iniciamos sendas mesas en sendos (V y IX) Congreso Internacional Latina de Comunicación Social en La Laguna (España), sobre "Infografía y visualización" primero (2013) y "Nuevas narrativas de la comunicación" (2017) después, investigadores de un lado y otro de Atlántico empezamos a reflexionar, escribir artículos, aportaciones investigadoras y técnicas del nuevo desarrollo visual sobre los contenidos, aplicados cada vez a un mayor número de campos. Los autores de este libro estudian pues algunas casuísticas comunicativas, como las propias de las disfunciones orgánicas de los seres humanos. Otros, con estudios de modelos educativos en niños y niñas y adultos en función de la semiología y la apropiación social del conocimiento. Otros desde campos universitarios más próximos al arte y/o la comunicación. Y por fin, otros desde los ámbitos mas teóricos del periodismo visual.
\end{abstract}

\section{Palabras clave}

Infografía, nuevas narrativas, visualización, conocimiento.

\section{Cómo citar este libro}

Autor capítulo (2018): “Título del capítulo", en Nuevas narrativas visuales. José Luis Valero Sancho (dir). Cuadernos Artesanos de Comunicación, 150. La Laguna (Tenerife): Latina 
José Luis Valero Sancho (diretor)

Aitor Castañeda Zumeta (editor)

Prefácio: José Luis Valero Sancho

\title{
Novas narrativas visuais
}

\author{
Autores: Aitor Castañeda, Jordi Català, Hernán \\ Franco, Mariana Lapolli, Beatriz Elena Marín- \\ Ochoa, Federico Medina, Francesc Morera, William \\ Robson, José Luis Valero, Tarcísio Vanzin.
}

Quando iniciamos as respectivas mesas no (V e IX) Congreso Internacional Latina de Comunicación Social em La Laguna (Espanha) sobre "Infografia e visualização" primeiro (2013) e "Novas narrativas da comunicação" depois (2017), investigadores de um lado e outro do Atlântico começamos a refletir, escrever artigos, trazer contribuições investigativas e técnicas do novo desenvolvimento visual sobre os conteúdos, aplicados a um número cada vez maior de áreas. Os autores deste livro estudaram alguns casos comunicativos, como os próprios das disfunções orgânicas dos seres humanos. Outros, com estudos de modelos educativos para meninos e meninas, assim como adultos, em função da semiologia e a apropriação social do conhecimento. Outros, a partir de campos universitários mais próximos da arte e/ou a comunicação. E por fim, outros, a partir de âmbitos mais teóricos do jornalismo visual.

\section{Palavras chave}

Infografia, novas narrativas, visualização, conhecimento.

\section{Como citar este livro}
Autor capitulo (2018): "Título do capítulo", em Novas narrativas visuais, José Luis Valero Sancho (dir). Cuadernos Artesanos de Comunicación. La Laguna (Tenerife): Latina 



\section{Siglas}

\section{Universidades de origen de los autores}

Brasil

UCS Universidad de Caxias do Sul ucs.br

UFSC Universidad Federal de Santa Catarina ufsc.br

UERN Universidad del Estado de Río grande del Norte $\underline{\text { uern.br }}$

\section{Colombia}

UdeA Universidad de Antioquia udea.edu.co

UPB Universidad Pontificia Bolivariana upb.edu.co

\section{España}

EHU Euskal Herriko Unibertsitatea Universidad del País Vasco ehu.eus

UB Universidad de Barcelona ub.edu

UAB Universidad Autónoma de Barcelona uab.cat

UOC Universitat Oberta de Catalunya Universidad Abierta de Cataluña uoc.edu

UPF Universidad Pompeu Fabra upf.edu

UVic Universidad de Vic uvic.cat 


\section{Siglas}

\section{Universidades de origem dos autores}

Brasil

UCS Universidade de Caxias do Sul ucs.br

UFSC Universidade Federal de Santa Catarina ufsc.br

UERN Universidade do Estado do Rio grande do Norte uern.br

\section{Colômbia}

UdeA Universidade de Antioquia udea.edu.co

UPB Universidade Pontifícia Bolivariana upb.edu.co

\section{Espanha}

EHU Euskal Herriko Unibertsitatea Universidade do Pais

Vasco ehu.eus

UB Universidade de Barcelona ub.edu

UAB Universidade Autônoma de Barcelona uab.cat

UOC Universitat Oberta de Catalunya Universidad Aberta de Catalunha uoc.edu

UPF Universidade Pompeu Fabra upf.edu

UVic Universidade de Vic uvic.cat 


\title{
A
}

\section{Prólogo}

\section{Nuevas narrativas visuales}

\author{
Dr. José Luis Valero Sancho
}

— L ÁMBITO de la comunicación hace tiempo que necesita un 1 nuevo diseño; en los albores de las carreras de periodismo se comenzaron a impartir asignaturas de diseño gráfico y arte, en las que se enseñaban contenidos relacionados con el arte bauhausiano del moderno arte ilustrado, combinado con las técnicas de distribución de grafismos y contragrafismos al modo de Harold Evans y las filosofías tipométricas o clasificatorias de Thibaudeau, seguidas fielmente en los manuales de gráficos italianos o españoles.

Eso era el diseño moderno: Se trataba de producir documentos más visuales, para atraer a los lectores que pasaban páginas en formatos poco versátiles del papel en sábana, tabloide o magazine. Conceptualmente se hablaba de visualidad como una forma de influir en la producción para que los lectores se sintieran cómodos en la lectura de papeles llenos de letras pequeñas y largas columnas estrechas o exageradamente anchas, en territorio de unos $7000 \mathrm{~cm} 2$ de papel entre las dos páginas, con los que manejarse en la lectura en el caso de la prensa diaria, pero también en revistas o libros con multitud de páginas de texto contínuo sin una sola separación o alteración. La edición tenía que cambiar.

Una de las primeras medidas fue la incoporación de directores de arte que transformaron los medios para generar presentaciones con mas colores, espacios blancos, imágenes, tamaños, contrastes y estéticas en 
general mas funcionales, que entraron en la comunicación para ayudar con el metalenguaje general.

Otra mas reciente fue la visualización que revolucionó el arte visual, pues entró a formar parte de los lenguajes y el contenido. El arte pasó de forma natural a complementar y sintetizar contenidos explicando visualmente cuestiones de forma alternativa a las tradicionales basadas en morfologías verbales tipográficas u orales. Con ello los signos no compusieron palabras y frases sino relatos completos sin limitaciones temáticas, tecnológicas o temporales.

La forma nueva de comunicación debía ser fundamentalmente visual pero también en pantalla, interactiva y multimedia, por lo que se puede decir que era mucho mas útil desde el punto de vista comunicativo y de expresión de contenido diversos. Por eso alguno de los autores de los textos que presentamos afirman que hoy día todo se puede producir técnicamente con infografías y desarrollar la expresión mediante narrativas muy visuales e icónicas, aunque sea sobre contenidos desprovistos de morfologías físicas en la naturaleza, como la que presenta cualquier evento inmaterial.

La comunicación visual actual reproduce acontecimientos, acciones o cosas por medio de propuestas técnicas al amparo de nuevas tecnologías. Es por tanto una manera directa, rápida, sintética y atractiva de construir relatos que sustituyen o implementan a otras vías tradicionales de explicar contenidos, que se recuerdan mejor y atraen más al intérprete, que las prefiere a los textos farragosos complejos de leer, poco atractivos y abstractos.

Hoy día la comunicación visual se lee o interpreta en pantallas y por ello se ha avanzado mucho en las presentaciones, que se preparan para unas generaciones humanas que han crecido con un importante bagaje de experiencias en teléfonos móviles, televisiones, ordenadores, blogs o redes divulgativas y colaborativas de forma generalizada. La comunicación visual y las herramientas de desarrollo de aquella como la infografía y la visualización de datos, son de gran utilidad en todas las profesiones y ciencias, tanto puras como aplicadas. 
Cuando iniciamos estas mesas en sendos ( $V$ y IX) Congreso Internacional Latina de Comunicación Social, sobre "Infografía y visualización" primero y "Nuevas narrativas de la comunicación" después, empezamos a reflexionar, escribir artículos, aportaciones investigadoras y técnicas del nuevo desarrollo visual sobre los contenidos, aplicados cada vez a un mayor número de campos.

Lo que era una herramienta de apoyo en el periodismo o la ciencia se convirtió en una forma alternativa de presentar relatos completos, que cada vez se han empleado mas en todas las disciplinas, al tiempo que se iba cambiando el término infografía para denominarla de manera general, pues parece superada y debe conceptualizarse mas ampliamente, por ejemplo, con conceptos como nuevas narrativas, visualización temática y de datos, imagen sintética o infografía multimedia e interactiva).

Los autores de este libro han estudiado algunas casuísticas comunicativas, como las propias de las disfunciones orgánicas de los seres humanos, en el caso de las investigaciones de la Dra. Lapolli y Dr. Vanzin de la UFSC. Otros, con estudios de modelos educativos en niños y niñas y adultos en función de la semiología y la apropiación social del conocimiento, como los de los profesores Dra. Marín Ochoa, Franco Higuita y Medina Cano de la Universidad Pontificia Bolivariana de Colombia; otros desde campos universitarios mas próximos al arte en la comunicación como el Dr. Morera, profesor del grado en Artes y diseño de la Escuela Massana, adscrita a la UAB; otros desde campos profesionales de la comunicación como Jordi Català, todo un referente pionero de la infografía como redactor jefe de El Periódico de Catalunya, que aparte de sus propias ponencias presentó una exposición infográfica sobre la obra de su equipo pionero en el mundo, que en su itinerancia se ha convertido en internacional; otros desde los ámbitos mas teóricos del periodismo visual como, desde España, el Dr Aitor Castañeda de la EHU o el profesor que suscribe, de la UAB. y por último también se han sumado otras colaboraciones que han incorporado un gran apoyo, como la de doctorandos como William Robson de la UFSC, ya mencionada para otros departamentos. También es importante reconocer y dar las gracias a otras colaboraciones que fueron recibidas en estas mesas, de profesores y 
estudiosos diversos, que con sus comunicaciones aportaron nuevas ideas y debate a ambas mesas.

Aprovecho para rendir un homenaje especial al Dr. José Manuel de Pablos Coello, profesor, guía y sobretodo amigo de todos nosotros, sin el que no hubiera sido posible editar este soporte. 


\title{
Prefácio
}

\section{Novas narrativas visuais}

\author{
Dr. José Luis Valero Sancho (tradução de Mariana Lapolli)
}

$\mathrm{O}$ CAMPO da comunicação, há tempos, necessita de um novo desenho; no alvorecer das carreiras de jornalismo, começaram a oferecer disciplinas de design gráfico, nas quais se ensinavam conteúdos relacionados à arte bauhausiana da arte moderna ilustrada, associadas às técnicas de distribuição de grafismos e contragrafismos, à maneira de Harold Evans e às filosofias tipométricas ou classificatórias de Thibaudeau, fielmente seguidos nos manuais gráficos italianos ou espanhóis.

Isto era o design moderno: tratava-se de produzir documentos mais visuais, para atrair os leitores que folheavam páginas em formatos poucos versáteis do papel em standard, tablóide ou berliner. Conceitualmente, se falava em visualidade como uma forma de influenciar a produção para que os leitores se sentissem à vontade na leitura de papéis repletos de pequenas letras e longas colunas estreitas ou exageradamente largas, em um território de cerca de $7000 \mathrm{~cm} 2$ de papel, contando com duas páginas, nas quais tinham que lidar com a leitura, no caso da imprensa diária, assim como em revistas ou livros com diversas páginas de texto contínuo sem uma única separação ou alteração. A edição havia de mudar.

Uma das primeiras medidas foi a incorporação de diretores de arte, que transformaram os meios, para gerar apresentações com mais cores, espaços em branco, imagens, tamanhos, contrastes e estéticas em geral 
mais funcionais, que entraram na comunicação para ajudar com a metalinguagem geral.

Outra, mais recente, foi a visualização que revolucionou a arte visual, pois passou a fazer parte de linguagens e conteúdos. A arte passou, de forma natural, a complementar e sintetizar conteúdos, explicando visualmente questões de forma alternativa às tradicionais, embasadas nas morfologias verbais tipográficas ou orais. Com isso, os signos não compunham palavras e frases, mas relatos completos sem limitações temáticas, tecnológicas ou temporais.

A nova forma de comunicação deveria ser fundamentalmente visual, mas também em tela, interativa e multimídia, portanto, pode-se dizer que ela foi muito útil do ponto de vista comunicativo e de expressão de conteúdos diversos. Por isso, alguns autores dos textos que apresentamos afirmam que, hoje em dia, tudo pode ser produzido tecnicamente com infografias e a expressão pode ser desenvolvida por meio de narrativas muito visuais e icônicas, mesmo que sejam sobre conteúdos desprovidos de morfologias físicas na natureza, como aquelas que apresentam qualquer evento imaterial.

A comunicação visual atual reproduz eventos, ações ou coisas por meio de propostas técnicas amparadas nas novas tecnologias. É, portanto, uma maneira direta, rápida, sintética e atrativa de construir narrativas que substituem ou implementam outras formas tradicionais de explicar conteúdos, que são mais lembradas e atraem mais aos intérpretes, que as preferem a textos sobrecarregados de leitura complexa, pouco atrativos e abstratos.

Atualmente, a comunicação visual é lida ou interpretada em telas e, por isso, evoluiu muito nas apresentações, que são preparadas para as gerações humanas que cresceram com uma importante bagagem de experiências em telefones móveis, televisões, computadores, blogs ou redes informativas e colaborativas de forma generalizada. A comunicação visual e suas ferramentas de desenvolvimento, como a infografia e a visualização de dados, são de grande utilidade em todas as profissões e ciências, tanto puras como aplicadas. 
Quando iniciamos estas respectivas mesas no (V e IX) Congreso Internacional Latina de Comunicación Social, sobre "Infografia e visualização" primeiro, e "Novas narrativas da comunicação" depois, começamos a refletir, escrever artigos, trazer contribuições investigativas e técnicas do novo desenvolvimento visual sobre os conteúdos, aplicados a um número cada vez maior de áreas.

O que era uma ferramenta de apoio no jornalismo ou na ciência se converteu em uma forma alternativa de apresentar as narrativas completas, que tem sido cada vez mais utilizada em todas as disciplinas, ao mesmo tempo em que o termo infografia foi sendo modificado para descrevê-la de maneira geral, pois parece ultrapassado e deve ser conceitualizado mais amplamente, por exemplo, com conceitos como novas narrativas, visualização temática e de dados, imagem sintética ou infografia multimídia e interativa.

Os autores deste livro estudaram alguns casos comunicativos, como os próprios das disfunções orgânicas dos seres humanos, no caso das investigações da Dra. Lapolli e Dr. Vanzin da UFSC. Outros, com estudos de modelos educativos para meninos e meninas, assim como adultos, em função da semiologia e a apropriação social do conhecimento, como os trabalhos dos professores Dra. Marín Ochoa, Franco Higuita e Medina Cano da UPB; outros, a partir de campos universitários mais próximos da arte na comunicação, como o Dr. Morera, professor de graduação em Artes e Design da Escola Massana, ligada à la UAB; outros, a partir de campos profissionais da comunicação, como Jordi Català, uma referência pioneira da infografia como redator-chefe do El Periódico de Catalunya que, além de seus próprios trabalhos, apresentou uma exposição infográfica sobre a obra de sua equipe pioneira no mundo que, em sua itinerância, tornou-se internacional; outros, e desde Espanha, a partir de âmbitos mais teóricos do jornalismo visual, como o Dr. Aitor Castañeda da EHU ou o professor que vos escreve, da UAB. Por último, também foram somadas outras contribuições que incorporaram um grande apoio, como as dos doutorandos, como William Robson da UFSC, já mencionada por outros departamentos. Também é importante reconhecer e agradecer a outras colaborações, que foram recebidas 
nessas mesas, de professores e estudantes diversos, que com suas publicações trouxeram novas ideias e debates a ambas as mesas.

Aproveito para prestar uma homenagem especial ao Dr. José Manuel de Pablos Coello, professor, guia e, sobretudo, amigo de todos nós, sem o qual não seria possível editar este livro. 


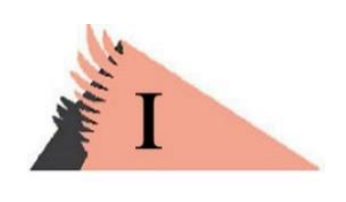

\title{
La infografía, contra el terrorismo. Los grupos informativos vascos y el 17A
}

\author{
Aitor Castañeda ( $\mathrm{G}$ ). Departamento de Comunicación \\ Audiovisual y Publicidad. EHU, España \\ aitor.castaneda@ehu.eus
}

Resumen. En el presente texto se analiza la calidad de la infografía impresa en los diarios de información general de los dos grupos más relevantes de la Comunidad Autónoma del País Vasco (España): Vocento y Grupo Noticias. Los infográficos estudiados versan en torno al atentado yihadista del 17 de agosto de 2017 perpetrado en Barcelona, procediendo a estudiar los mismos durante la segunda quincena de agosto del 2017 midiendo su calidad a través del método del académico español Valero Sancho, gracias al cual se obtienen índices de calidad empleando una fórmula numérica. Los resultados dejan ver que es grupo Vocento quien cuenta con los periódicos que publicaron un mayor número de infografías y de mejor calidad, si bien los diarios de Noticias muestran una incipiente calidad informativa y dejan entrever la fe del actual periodismo vasco por el infográfico en prensa.

Palabras clave: Infografía, País Vasco, prensa, prensa local, terrorismo. 


\section{Introducción. El 17 de agosto de 2018}

T AS SIGUIENTES líneas desarrollan un estudio infográfico a 1 partir de un grave altercado sucedido en la ciudad de Barcelona el 17 de agosto del 2018, conocido periodísticamente como 17A.

Tal como se recogió en la prensa, y tal como desgraciadamente pasará a nuestra historia, España fue víctima del Estado Islámico o Dáesh aquel jueves 17, en el que una furgoneta conducida por un joven de 22 años -identificado después como Younes Abouyaagoub- arrollaba a más de un centenar de personas en el emblemático paseo de la Rambla de la capital catalana, dejando trece fallecidos y otros ciento treinta heridos. Tras estrellarse contra un quiosco, el delincuente pudo hacerse con un automóvil y atropelló después a un viandante y a un mozo de escuadra ${ }^{1}$, huyendo posteriormente y por fin muriendo a fuego por la policía en el municipio barcelonés de Subirats, cuatro días después de que escapara.

Además de él, otros siete compañeros de célula compartieron el mismo final: cinco fueron tiroteados por la policía autonómica en el Paseo Marítimo de Cambrils - provincia de Tarragona- dos días antes de la muerte de Abouyaagoub, mientras perpetraban un atentado en aquel municipio (SER, 2017). Los dos restantes fallecieron un día antes del $17 \mathrm{~A}$ tras sufrir una explosión en la villa tarraconense de Alcanar cuando se hallaban manipulando los explosivos de los que se disponían a hacer uso un día después. Uno de estos últimos era Abdelbaki Es Satty, imán de Ripoll -Gerona- y cabeza de la célula, fruto de cuya obra son hoy 16 víctimas mortales de seis nacionalidades distintas -contando a los terroristas- y más de un centenar de heridos (El País, 2017).

El suceso, que impactó a toda la comunidad internacional, fue cubierto por los medios más relevantes del mundo, sumándose así España a la lista de países europeos que han sufrido atentados yihadistas. Sus medios retransmitieron constantemente la información durante todo

\footnotetext{
${ }^{1}$ Miembro de la policía autonómica de Cataluña, en su lengua y oficialmente Mossos d'Esquadra.
} 
agosto, destacando los datos que se iban revelando en torno al acontecimiento.

Concretamente, en el ámbito que se estudia en esta breve investigación, el País Vasco -región que se encuentra entre las líderes en penetración periodística en España (Ymedia, 2017: 6)-, los principales grupos de información publicaron, a través de sus cabeceras impresas, muy llamativas infografías, cuya calidad se estudia aquí.

\section{Qué es la infografía periodística}

Antes de proceder a determinar las líneas generales de esa investigación, debe ponerse en relieve el interés de la infografía desde el periodismo, si bien se ha dicho ya que la prensa del ámbito geográfico que se estudia es de los más importantes de España. Así, debe definirte primeramente la infografía, para a continuación poner de manifiesto su valor informativo y justificar el objeto de estudio.

La infografía, también infográfico - del inglés infographics o information grabics - es definida según la RAE como "técnica de elaboración de imágenes mediante computadora", aunque centrándose en el campo periodístico, el diccionario añade que se trata de una "representación gráfica que apoya una información de prensa". Ambas definiciones resultan inadecuadas para lo que aquí atañe, en tanto que según la primera, toda imagen creada a través de soportes informáticos sería siempre infografía, e invalidaría toda producción infográfica anterior a la existencia de los ordenadores (Valero, 2001: 25). Hoy se sabe que la raíz 'info' del término no deriva de 'informática', sino de 'información', aunque 'informática' también hunda su raíz en la tierra de la 'información automática' (De Pablos, 1998: "La sinergia de la comunicación subrayada", pár.5). En tal sentido, toda información que se quisiera transmitir a través del lenguaje gráfico sería una infografía.

Así las cosas, podría definirse la infografía como una representación diagrámica de datos, siendo un diagrama un "dibujo en el que se muestran las relaciones entre diferentes partes de un conjunto o sistema" (Cairo, 2008: 21). Combina texto e imagen (De Pablos, 1998: "El concepto bI+T", pár.1), y se vale de formas simbólicas e icónicas, pudiendo ser también acompañadas de texto, siendo el diagrama la base de las mismas. 
Publicadas en soporte digital, pueden contar también con elementos auditivos (Valero, 2001: 201).

Por su gran utilidad comunicativa para representar la información, la infografía haya sido casi siempre objeto de estudio del periodismo, donde se ha desarrollado con mayor potencial, constituyendo en ocasiones no solo un complemento a la información textual, sino la articulación integral de la misma (Valero, 2001: 57; 2009: 52). Así las cosas, una infografía puede contar con tal potencial informativo que puede incluso sustituir a un artículo periodístico, si bien no debe competir con él (Leturia, 1998: pár.4).

\section{Grupos de información en el País Vasco}

Habiendo concluido qué es la infografía, se plantea analizar la calidad informativa de los infográficos de los diarios impresos de información general de los dos grupos de información más importantes del País Vasco -también Comunidad Autónoma Vasca o Euskadi-, publicadas desde el 17A hasta el último día de agosto del 2017. Dichas infografías versan en torno al suceso al principio relatado.

Es pertinente aportar aquí la peculiar situación sociológica de la región que se está estudiando. Es así el País Vasco ${ }^{2}$ un territorio autónomo de España, con el vascuence -también vasco o eusquera- como lengua propia junto al castellano. La región está formada por tres provincias históricas: Vizcaya -o Biqkaia en vasco, cuya capital es Bilbao o Bilbo-, Guipúzcoa -o Gipurkoa, capital San Sebastián o Donostia- y Álava -o Araba, capital Vitoria o Gasteiz-, las tres dotadas a su vez de autonomía administrativa.

\footnotetext{
${ }^{2}$ Nótese que se habla aquí del País Vasco en términos jurídicos, si bien en el campo etnológico -y también literario- se le ha denominado así al conjunto de territorios transfronterizos de habla vasca, que además de las provincias mencionadas, suman también a Navarra y al país vascofrancés (Jacob, 1994: xv), dando origen al conjunto territorial también denominado Euskal Herria o Euscalerría.
} 
$\mathrm{El}$ interés por la lectura de prensa en este territorio, ligado desde hace décadas a su problemática nacional ${ }^{3}$, así como a la importante presencia de sedes periodísticas en él -ya desde los años 70, dos de los siete diarios de mayor tirada nacional estaban en la villa de Bilbao ${ }^{4}$-, convierten la comunidad en un espacio de importante interés analítico del periodismo.

A día de hoy existen dos grupos informativos predominantes en la Comunidad en lo que a periódicos se refiere, a saber, ${ }^{\circledR}$ Vocento y el grupo ${ }^{\circledR}$ Noticias. Ambos compiten con sus diarios de información general por ganarse el liderazgo de la audiencia en las provincias, siendo así El Correo Español-El Pueblo Vasco -o también y solamente El Correode Vocento el diario más leído del territorio, con una audiencia de 851.000 lectores diarios según la empresa de estudios de mercado ${ }^{\circledR}$ CIES $^{5}$ (2016), quien computa las audiencias del País Vasco y de Navarra.

Asimismo, y aunque no vayan a ser estudiados en este manuscrito, cabe mencionar otros grupos de diversas cabeceras de influencia en la región, como lo son ${ }^{\circledR}$ Prisa, editor de la edición local del diario El País; ${ }^{\circledR}$ Unidad Editorial, a quien pertenece ElMundo del siglo XXI; la Sociedad para el Desarrollo de los Medios de Comunicación Vascos, de siglas eusquéricas ${ }^{\circledR}$ EKHE SA, creadores del diario Gara-'somos'-; y por fin

\footnotetext{
3 Aunque no se estima pertinente profundizar en las causas y devenir de dicho conflicto, baste saber que una importante base electora del País Vasco considera su tierra una nación, lo que se percibe con especial intensidad en Vizcaya y Guipúzcoa, algo menos en Álava y Navarra, y muy poco en la región vascofrancesa. El estatuto de autonomía del País Vasco -Ley Orgánica 3/1979, 18 de diciembre- reconoce a Euskadi caracteres nacionales a través de su artículo 1 -"El Pueblo Vasco [...], como expresión de su nacionalidad [...], se constituye en Comunidad Autónoma dentro del Estado español bajo la denominación de Euskadi o País Vasco"-, y concede a Navarra el derecho a regirse por este mismo estatuto a través de su artículo 2 -"Alava, Guipúzcoa y Vizcaya, asi como Navarra, tienen derecho a formar parte de la Comunidad Autónoma del País V asco"- (Gobierno, 1979).
}

${ }^{4}$ Esto son, El Correo Español-El Pueblo Vasco, con una tirada de 89 mil ejemplares (Oficina para la Justificación de la Difusión OJD, 1977) y el ya extinto La Gaceta del Norte, con 77.500 (OJD, 1977).

${ }^{5}$ http://www.ciessl.com 
${ }^{\circledR}$ Euskal Editorea SM, creadores de Berria -'noticia'-, único periódico íntegramente escrito en lengua vasca.

Así pues, Vocento, grupo español propietario del muy conocido periódico A $b c$ es la empresa informativa líder en Euskadi. Junto con El Correo, decano de Vizcaya y de Álava ${ }^{6}$ a través de sus ediciones provinciales, Vocento cuenta también con Diario V asco, el periódico más leído en Guipúzcoa y en la comarca de Eibar-Mondragón, así como en el valle navarro del Baztán.

El Correo cuenta así, en miles, con 341 lectores en Vizcaya y 95 en Álava, y Diario Vasco con 230 en toda Guipúzcoa (CIES, 2016).

Le sigue a Vocento, y a nivel regional, el diario Deia, de Noticias, con 85.000 lectores en toda Euskadi, concentrando su mayor audiencia en Vizcaya -no en vano, su nombre completo es Deia-Noticias de Bizkeaia-. Nótese aquí la peculiaridad de su nombre, cuyo significado en vascuence es 'llamada', y que, aunque está escrito en castellano, introduce los topónimos en ortografía eusquérica -Biøkaia-, mostrando su talante vasquista o nacionalista vasco.

\begin{tabular}{clc} 
Grupo Diarios & \multicolumn{2}{l}{$\begin{array}{l}\text { Sigla Audiencia } \\
\text { (en miles) }\end{array}$} \\
Vocento El Correo & EC & \multicolumn{2}{c}{441} \\
Diario Vasco & DV & 233 \\
& \multicolumn{3}{c}{085} \\
Noticias Deia & - & \\
Noticias de Gipurkoa & NG & 027 \\
Diario de Noticias de Álava & DNA & 020
\end{tabular}

Tabla 1. Audiencia de los diarios estudiados. Fuente: CIES, 2016

En la provincia alavesa, Noticias compite con El Correo reuniendo 20.000 lectores en torno a Diario de Noticias de Álava, segundo periódico más leído de este territorio, y en Guipúzcoa con Noticias de Gipuحkoa, aunque en este caso el periódico es el cuarto en el escalafón, con 26.000

- La edición alavesa de El Correo es también leída en los municipios burgaleses de Treviño, enclavado en Álava, y Miranda de Ebro, limítrofe. 
lectores, por detrás de Berria, que suma 29.000 en la provincia, y de Gara, con 35.000.

Las siglas recogidas en la son utilizadas por los mismos diarios en su difusión en redes sociales y otros soportes. Serán nombrados todos ellos de aquí en adelante de esta manera, abreviando su extensión y facilitando la lectura.

\subsection{Ideología y lengua de los grupos informativos}

Vocento y Noticias poseen ideologías diferentes. El primero se adhiere manifiestamente a la Constitución española, afirmando en su libro de estilo que: "Vocento está comprometido explícitamente con la legalidad democrática que bajo el amparo de la Corona definen la Constitución de 1978, asi como las leyes que la desarrollan y los estatutos de autonomía" (De Sousa, 2003: 19). Por otra parte, Noticias hace suyo el compromiso de Deia, precursor del grupo, con las bases moderadas del Partido Nacionalista Vasco o PNV, así afirmado por el editorial del 2 de enero del citado periódico al cumplir el mismo cuarenta años en 2017 -"Deia ha sido desde sus inicios un proyecto [...] surgido gracias al impulso de miles de suscriptores que eligieron tener su propio medio centrado en la visión de Euskadi y del mundo desde la sensibilidad propia, la identificación con la cultura y la especificidad social vasca y generado a partir de las prioridades, inquietudes y necesidades de la ciudadanía de este pais"--.

Llama la atención que la ideología de Vocento no se ajuste del todo al color de las tendencias políticas más votadas de la Comunidad, más cercanas a las de Noticias, si bien hay que remarcar que mientras que los actuales diarios de Vocento tienen casi un siglo, Deia y en general su grupo informativo suman menos de la mitad de uno, contando los primeros con un importante recorrido en Euskadi.

"En Bilbao [...] El Pueblo Vasco se fusionó en 1938 con El Correo Español. Esta fusión sería el germen de una larga historia de alianzas entre familias de editores de prensa en España que daría lugar a la incorporación progresiva de [...] El Diario Vasco de San Sebastián" (Vocento, 2017: "1864-1910", pár.2). 
En lo referente a la lengua, todos los diarios estudiados se publican en castellano, idioma mayoritario de la población ${ }^{7}$. No obstante, todos ellos publican algunos contenidos en vascuence, siendo los de Vocento quienes más explícitamente se comprometen con el uso del castellano: "Los periódicos de Vocento se editan en lengua española, excepto en las secciones o apartados que cada publicación estime convenientes" (De Sousa, 2003: 25).

\section{Referencias teóricas para el estudio de la infografía}

Centrando ya el estudio en la infografía periodística desde lo académico, el infográfico de prensa ha sido sustancioso objeto de estudio para investigadores de las comunicaciones sociales. Acotando el objeto a las representaciones infográficas de conflictos bélicos o de gran alcance social, debe citarse el estudio de Zamarra (1996), donde a través de los diversos relatos periodísticos sobre la Guerra del Golfo 1990/91- se demuestra la consolidación de la infografía como medio a través del cual cualquier relato periodístico puede ser narrado.

Por otra parte, en lo referente al ámbito de estudio de la infografía en medios de comunicación del País Vasco no puede dejar de mencionarse la tesis de García-González (2012), donde se analiza la producción infográfica del diario EC desde 1910 hasta el 2012 desde una perspectiva histórica que abarca métodos, rutinas y condiciones de trabajo de los infografistas del diario, obteniendo una imagen que destaca la excelencia de la producción gráfica del periódico.

Sin embargo, es en lo referente a los métodos de estudio de la infografía donde se encuentras grandes obras de valor. Según la literatura a la que se ha tenido acceso, las dos grandes metodologías de medición de calidad infográfica que existen hoy son las de Valero (2001) y Colle (2004), ambas comparadas en la tesis de Chimeno, quien opta por medir la eficacia de las infografías a través de cuestionarios a grupos estudio (Chimeno, 2015: 47-48). La principal diferencia entre los dos primeros es que mientras el último establece un patrón de análisis crítico en la que evalúa una serie de premisas de naturaleza descriptiva

${ }^{7}$ Actualmente casi un $40 \%$ de la población del País Vasco mayor de 2 años es bilingüe, cifra a la que hay que sumar otro $25 \%$ más de casi vascohablantes (Eustat, 2011). 
entre las diversas partes de una infografía -texto, equilibrio de formas, estética, etc.-, el primero aporta a cada característica o propiedad de la infografía un valor numérico -0 ausencia, 1 apariencia de la propiedad-, y colectando todos los valores obtenidos sustrae un índice cuya posición en una escala determinará la calidad de una infografía.

Ambos métodos pueden aplicarse a una infografía, teniendo previamente en cuenta que el primero es primordialmente cualitativo, mientras que el segundo opera con valores numéricos e índices. Los dos son también aplicables tanto a la producción impresa como digital.

La metodología que se emplea aquí es la propuesta por Valero. Se prevé como el sistema idóneo para realizar una comparativa entre todos los infográficos que se estudian, y de cuya aplicación se extraen cifras que valoran con mucha precisión la calidad de las infografías, que como se ha dicho, serán aquéllas de los diarios de los dos grandes grupos informativos del País Vasco que aparezcan desde el 17A hasta el final del mes y cuya temática verse en torno al atentado.

Se parte del supuesto de que serán los periódicos de Vocento, por sus recursos, su audiencia y los planteamientos de García-González quienes crearán infografías de mayor calidad en comparación con los de Noticias, así como que la mayoría de los infográficos que se encuentren serán de tipo escénico, que se describirá en el siguiente epígrafe.

\subsection{Método de análisis}

Así las cosas, Valero propone que todo infográfico debe poder ser clasificado en una tipología concreta, si bien él realiza la suya propia y otros, como Colle, proponen otras diferentes (2004). Se definirán aquí aquellas tipologías que se han hallado en el estudio utilizando la clasificación de Valero, aunque los datos que aquí se ofrecen están circunscritos a las características de las infografías analizadas, por lo que para una explicación totalmente completa del método se recomienda la consulta de la bibliografía aquí citada. 
Con todo, para el académico de referencia en esta investigación, y centrándose en las infografías que aquí se han hallado, éstas pueden ser:

- Documentales. A pesar de que su nombre clasificatorio resulta un poco ambiguo -en tanto que todas las infografías pretenden en mayor o menor medida documentar-, los infográficos documentales pretenden la explicación detallada de características de acontecimientos, acciones o cosas, que suelen resultar relevantes para comprender una información (Valero, 2001: 139), sobre todo si la materia es de tipo técnico o requiere de ampliaciones adicionales, como puede ser el caso del funcionamiento de máquinas, del cuerpo humano o de algún suceso detallado que englobe diversos detalles.

- Escénicas. Muy parecidas a las anteriores, son más utilizadas para escenarios de atentados o complejos sucesos concatenados que requieren de explicaciones por escenas -a veces a modo de cómic-, como si los sucesos hubiesen sido vistos por una tercera persona. Se hipotetiza así que la mayoría de las estudiadas serán de este último tipo debido a la temática que se elige.

- Las ubicativas. Pretenden situar los hechos narrados en un espacio concreto, sirviéndose para ello de mapas, planos y espacios diseñados con objeto de situar al lector (Valero, 2001: 147).

Una vez se identifica la tipología del infográfico estudiado, será necesario analizar si el mismo cuenta con una serie de características básicas de toda infografía, que Valero enumera en siete:

1. Información. Cometido principal de la infografía, en tanto que como medio periodístico debe estructurar y organizar los datos, jerarquizándolos de en relevancia y respondiendo, como todo artículo periodístico, a las cuatro preguntas básicas: '¿Qué/Quién(es)?', '¿Cuándo?', '¿Dónde?' y '¿Cómo/Por qué?'. Una infografía es informativa cuando responde adecuadamente a esas cuatro preguntas. 
2. Significación. Una infografía es significativa si su información resulta relevante para el lector, a la par que útil y actual. La significación se completa atendiendo a las siguientes propiedades (Valero, 2001: 153):

- Claridad del asunto clave, si deja latente cuál es el suceso que se muestra.

- Familiaridad del acontecimiento con el público lector.

- Identificación de los elementos, personajes y acciones sobre los que se informa.

- Actualidad de los hechos.

3. Comprensión. Característica que dota a la infografía de una organización en sus elementos que la hace inteligible, en tanto que si sus elementos componentes son ambiguos la infografía resulta invisible (Valero, 2001: 161). La comprensión se evalúa a su vez teniendo en cuenta:

- la visibilidad, o complementación y estructuración adecuada de los textos e imágenes,

- la legibilidad, con una redacción sin faltas de ortografía y un lenguaje correcto,

- la claridad, siendo los símbolos y textos que se utilizan son claros y comprensibles,

- y el didactismo, si los datos son fáciles de memorizar y posibilitan la comprensión.

4. Estética. Característica que reviste la infografía de elementos artísticos, de belleza o gracia a la vista. Su ausencia no resulta determinante para la calidad del infográfico, siendo su principal cometido informar (Valero, 2001: 165), aunque sí que aporta en positivo a la misma. Entre las propiedades que se consideran estéticas están:

- los cada vez menos frecuentes retoques a mano,

- los detalles gráficos como remates o sombras, que Valero llama "gracias",

- el dinamismo en la disposición de los elementos

- y la originalidad del conjunto. 
5. Iconicidad. Característica que comprende el grado de aportación de mensajes figurativos no codificados, que representan con signos objetos y realidades al tiempo que las hace reconocibles para el lector (Valero, 2001: 169). Así, y al poder utilizar un infográfico fotos y dibujos que se acerquen lo más posible a la percepción de la realidad, se dirá que una infografía es icónica cuantos más elementos de este tipo contenga. Así: Aportan a la iconicidad las fotografías y figuras en perspectiva, y se la restarán las que contengan figuras abstractas $\mathrm{y} / \mathrm{o}$ planas, si bien hay que observar en cada caso cómo se disponen dichos elementos.

6. Tipografía. Refiere a los textos de los que la infografía se ayuda para informar, pues no se concibe infografía sin informaciones escritas (Valero, 2001: 173). Es importante entender que una infografía ha de contar:

- con un título que la identifique;

- con un crédito o firma de su autor, pues dependiendo de quién sea puede incluso aportarle prestigio a la obra;

- con textos explicativos, no mayores de 27 palabras,

- y con rótulos, que a modo de pequeños títulos identifican los aspectos más importantes narrados por la infografía.

7. Funcionalidad. Se habla de funcionalidad de la infografía respecto al texto escrito, en tanto que ésta será más funcional cuanto más se entienda por sí sola, aportando información que no figura en el artículo -complemento- o incluso sustituyendo toda la información escrita con una pieza de gran tamaño o megainfografía (Valero, 2001: 177). En el caso en que ésta resuma lo ya dicho, se hablará de la propiedad de síntesis.

\section{Característica Propiedades}

Información ¿Qué/Quién(es)? ¿Cuándo? ¿Dónde? ¿Por qué?

Significación Asunto clave Identificación Familiaridad Actualidad

Comprensión Visibilidad Claridad Legibilidad Didactismo

Estética Detalles a mano Dinamismo "Gracias" Originalidad

Iconificidad Abstracción Figuras en perspectiva

Figura

Plana Fotografías 
Tipografía Titulo Texto explicativo

Rótulos

Funcionalidad Sintesis

Proporción información

Complemento Proporción página

Tabla 2. Cláusulas de valoración de la infografía. Fuente: Valero, 2001

Todas las cualidades citadas deben existir bajo el prisma de la concordancia, es decir, aquella propiedad que obedece a las reglas y elementos mínimos para el uso social de la infografía (Valero, 2001: 179). Así, si un infográfico aporta una información no real o con carencias, se dirá que adolece de concordancia. También son errores de concordancia las faltas de ortografía, en tanto que no se pueden tolerar faltas al idioma en el que se escribe.

A este respecto es muy importante destacar que los diarios cuyas infografías que aquí se analizan tienden a escribir los topónimos del País Vasco en vascuence, a pesar de estar redactados en castellano. Esto se debe, en el caso de los del grupo Noticias, al estilo de escritura del lenguaje nacionalista vasco, quien mantiene los nombres en grafía eusquérica, independientemente de cualquier otro idioma en el que escriba. Baste apreciar las referencias toponímicas de cualquier documento del propio fundador del PNV, que aunque no coincidan con la ortografía éuscara actual, dejan ver un estilo que sería respetado hasta hoy por simpatizantes de esa tendencia:

"Siendo Bizkaya $a^{8}$, por su raza, su lengua, su fe, su carácter y sus costumbres, hermana de Alaba', Benabarre ${ }^{10}$, Gipu₹koa, Lapurdi"11, Nabarra ${ }^{12}$ y Suberoa $^{13}$, se ligará o confederará con estos seis pueblos" -Arana en Bizkaitarra, no 10 (Elorza, 1995: 229)-.

\footnotetext{
${ }^{8}$ Hoy Bizkaia en vascuence.

9 Hoy Araba.

${ }^{10}$ Baja Navarra, en el País vascofrancés. En francés Basse-Navarre, y hoy en vascuence Behe Nafarroa o Nafarroa Beherea.

${ }_{11}$ Labort, en el País vascofrancés. En francés Labourd, y hoy en vasco Lapurdi o Laburdi.

${ }_{12}$ Hoy en vascuence Nafarroa.

${ }_{13}$ Sola, en el País vascofrancés. En francés Soule. En suletino, dialecto del eusquera, Xiberüa, y hoy en vascuence normalizado Zuberoa.
} 
Por la misma solidaridad nacionalista escribe los nombres de otros países o regiones en su idioma propio, como Catalunya en vez de Cataluña, como se aprecia en la infografía de NG 19:1214.

Por otra parte, y debido a la oficialización de la lengua vasca desde la entrada en vigor de la Constitución ${ }^{15}$, diversos municipios y provincias oficializaron sus nombres solamente en el idioma autóctono, obligando así a los medios a redactar los topónimos a la manera acordada, como es el caso de los diarios de Vocento, cuya edición vizcaína es, por ejemplo, El Correo-Bizkaia -y no 'Vizcaya'-.

En cualquier caso, ninguna de estas apreciaciones constituye errores de concordancia, sino peculiaridades de estilo -e ideología- de los periódicos estudiados.

\subsubsection{Codificación}

Habida cuenta de todos los parámetros establecidos anteriormente, Valero propone codificar cada una de esas características a través de un sistema binario de ceros y unos. Así, para que una infografía obtenga un nivel $\mathrm{X}$ de significación, deberá sumar 0 o 1 a sus propiedades claridad -0 , si no hay claridad; 1 , si la infografía es lo suficientemente clara-; 0 o 1 al de familiaridad, otro tanto a la de identificación y a la de actualidad. Finalmente, el valor X será el resultado de la suma de los ceros y unos derivados de cada propiedad que configuran la característica de significación, y así, con todas las demás características anteriormente descritas.

Quien analiza debe ir valorando, en base a su criterio lo más preciso posible, qué cifra corresponde a cada propiedad, en tanto que siempre que tenga dudas sobre si una infografía es o no, por ejemplo, clara, evalúe como 0 en vez de 1.

\footnotetext{
${ }^{14}$ De aquí en adelante se citan las infografías con la sigla del diario donde se encuentran, junto con la cifra del día correspondiente -en tanto que todas son de agosto de 2017- y las páginas donde se hallan.

${ }_{15}$ En su artículo 3 se especifica que "El castellano es la lengua española oficial del Estado", pero añade: "Las demás lenguas españolas serán también oficiales en las respectivas comunidades autónomas de acuerdo con sus estatutos" (Congreso de los diputados, 2003).
} 
Cabe tener en cuenta sin embargo que, para la funcionalidad, si bien se establece el código binario 0-1 para las propiedades de síntesis y complemento, no es así para otras dos que se incluyen en la fórmula: la proporción en la página -o porción de espacio que ocupa la infografía en la hoja del periódico- y la proporción de la información, es decir, la cantidad de información nueva que aporta respecto al texto escrito, pudiéndose tratar de un complemento del mismo o bien de algo novedoso. En cualquiera de ambos casos, el valor que se obtiene deriva de una escala del 0 al 1.

En el caso de las infografías de gran tamaño o megainfografías, que ocupan toda la página narrando un acontecimiento, el valor de funcionalidad será siempre de 4, el máximo (Valero, 2001: 185).

Por fin, cada característica podrá colectar un valor máximo de 4, extraído de la suma de cada una de sus cuatro propiedades. Finalmente, el valor de la infografía analizada se traducirá en un índice derivado de la siguiente fórmula:

$$
\begin{aligned}
\text { Valor } & =100(\text { Información }+ \text { Significación }+ \text { Comprensión }+ \text { Estética } \\
& + \text { Iconificidad }+ \text { Tipografía }+ \text { Funcionalidad }) / 28
\end{aligned}
$$

Como se aprecia, multiplicar por 100 y dividir entre 28 permite obtener un valor centesimal a partir de los 28 posibles valores que puede dar el resultado - siete características por cuatro propiedades cada una-. El resultado situará el valor de la infografía en una escala que permitirá evaluarla:

- Inaceptable (I), cuando se obtenga un valor inferior a 40.

- Regular (R), cuando el valor esté comprendido entre 40 y $49^{\prime} 9$.

- Suficiente (S), cuando esté comprendido entre 50 y $59^{\prime} 9$.

- Notable (N), cuando esté entre 60 y 69'9,

- y excelente (E), cuando el valor sea 70 o más.

Debe tenerse asimismo en cuenta:

- Que todas las infografías estudiadas han de poder identificarse en sus respectivas tipologías. 
- Que todas deben responder a la concordancia. Cada falta de ortografía resta 12,5 puntos al total.

- Que ninguna característica puede tener un valor de 0 salvo la estética.

\section{Resultados}

De las infografías colectadas para este análisis, Vocento reúne la mayor cantidad: cinco para $E C$ y cuatro para $D V$-nueve en total-, mientras que los tres diarios de Noticias suman siete, siendo tres para Deia, otras tres para $D N A$ y solo una para $N G$.

\section{Cantidad de infografías recolectadas por diarios}

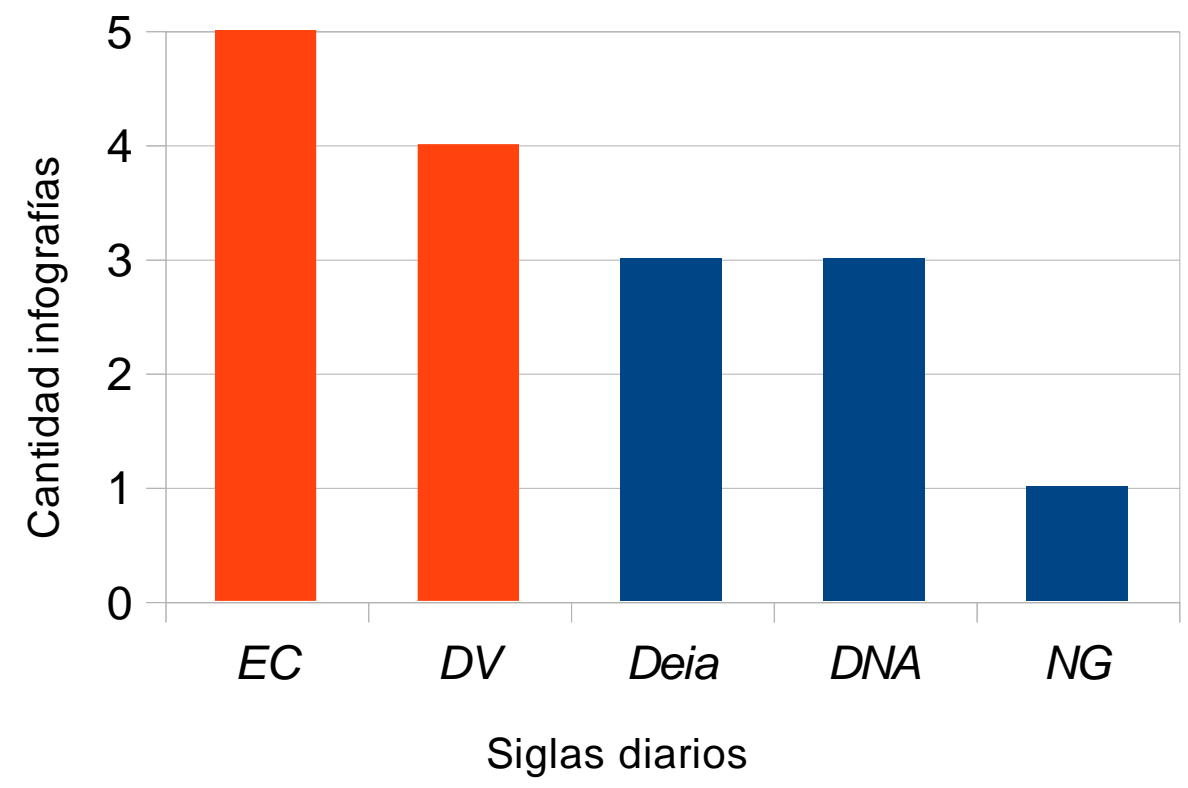

Gráfico 1. Fuente: Propia. 


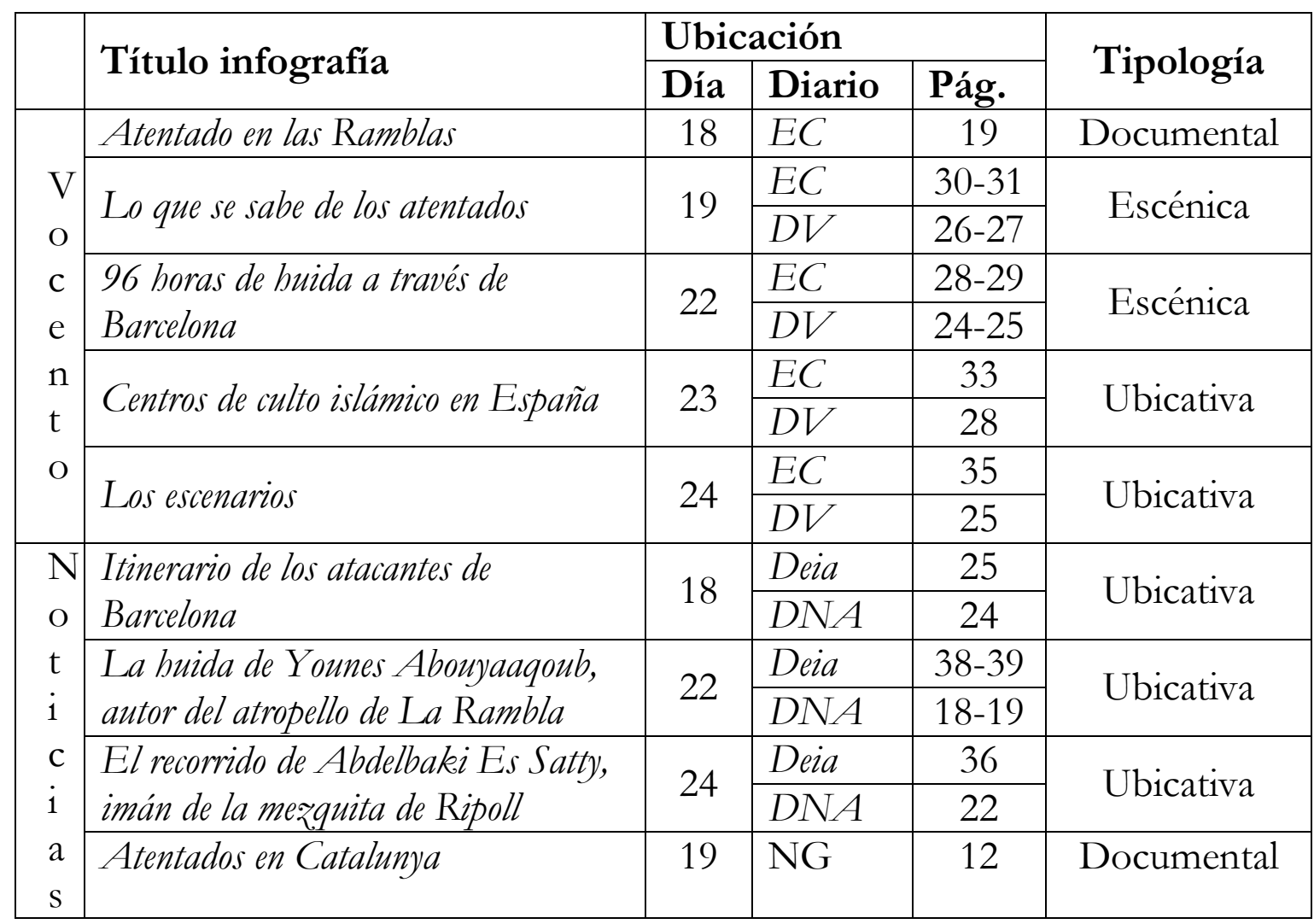

Tabla 3. Infografías colectadas por diarios. Fuente: Propia.

Sin embargo, y tal como se aprecia en la tabla, esa única de $N G(19: 12)$ es original de este periódico, siendo las tres de Deia y $D N A$ las mismas en todos los casos, utilizando el grupo el mismo material. Lo mismo ocurre en el caso de Vocento, en el que salvo la infografía de EC 18:19, todas las demás son iguales para ambos diarios. Esto deja entrever la dinámica de trabajo de ambos grupos, creando entre sus periódicos una considerable interdependencia según los contenidos.

Los datos de la tabla muestran asimismo que la infografía predominante es la de tipo ubicativo, en tanto que los infográficos estudiados pretenden en su mayoría situar los acontecimientos del 17A en las distintas zonas donde fueron perpetrados. Así también la infografía del día 23 (EC:33, DV:28) muestra una España dividida en comunidades autónomas, señalando con colores más intensos aquéllas en las que más abundan las mezquitas. Si bien obviamente y por sí solo esto no tiene nada que ver con el terrorismo, la infografía se halla complementando un reportaje sobre los imanes radicalizados en 
España ${ }^{16}$, por lo que engancha con la agenda de los diarios que durante aquel mes estuvieron profundizando en torno al día 17.

$\begin{array}{ll}\text { Tipos } & \mathbf{N}^{\mathbf{0}} \\ \text { Ubicativas } & 10 \\ \text { Escénicas } & 04 \\ \text { Documentales } & 02\end{array}$

Tabla 4. Tipos de infografías analizadas. Fuente: Propia.

Cabe destacar además la importante cantidad de megainfografías recolectadas, casi todas ellas en EC y del $D V$, donde a través de infográficos que ocupan toda una página o dos, explican con gran minuciosidad de detalle el suceso narrado. Es, en el caso de EC, la 19:30-31, 22:28-29 y 24:35 -lo equivalente en $D V$ a 19:26-27, 22: 2425 y 24:25 respectivamente-, y en Deia, la 22:38-39 (DNA 22:18-19). En total, ocho megainfografías que suman en su apartado de funcionalidad la máxima puntuación: 4 .

En lo que refiere al valor de los índices obtenidos a partir de la aplicación del método propuesto, los resultados son los que figuran en la siguiente tabla:

\begin{tabular}{|c|c|c|c|c|c|}
\hline & \multirow{2}{*}{ Título infografía } & \multicolumn{3}{|c|}{ Ubicación } & \multirow{2}{*}{$\begin{array}{c}\text { Índice } \mid \\
* \text { Calificación }\end{array}$} \\
\hline & & Día & Diario & Pág. & \\
\hline \multirow{3}{*}{$\mathrm{V}$} & Atentado en las Ramblas & 18 & $E C$ & 19 & $82^{\prime} 9 \mid \mathrm{E}$ \\
\hline & \multirow{2}{*}{ Lo que se sabe de los atentados } & \multirow{2}{*}{19} & EC & $30-31$ & \multirow{2}{*}{$89 ' 3 \mid \mathrm{E}$} \\
\hline & & & $D V$ & $26-27$ & \\
\hline $\mathrm{c}$ & \multirow{2}{*}{$\begin{array}{l}96 \text { boras de buida a través de } \\
\text { Barcelona }\end{array}$} & \multirow{2}{*}{22} & $E C$ & $28-29$ & \multirow{2}{*}{$92,9 \mid \mathrm{E}$} \\
\hline e & & & DV & $24-25$ & \\
\hline $\mathrm{n}$ & \multirow{2}{*}{ Centros de culto islámico en España } & \multirow{2}{*}{23} & $E C$ & 33 & \multirow{2}{*}{$59^{\prime} 3 \mid \mathrm{S}$} \\
\hline $\mathrm{t}$ & & & $D V$ & 28 & \\
\hline \multirow[t]{2}{*}{$\mathrm{O}$} & \multirow{2}{*}{ Los escenarios } & \multirow{2}{*}{24} & $E C$ & 35 & \multirow{2}{*}{$67^{\prime} 9 \mid \mathrm{N}$} \\
\hline & & & $D V$ & 25 & \\
\hline \multirow{2}{*}{$\begin{array}{l}\mathrm{N} \\
\mathrm{O}\end{array}$} & \multirow{2}{*}{$\begin{array}{l}\text { Itinerario de los atacantes de } \\
\text { Barcelona }\end{array}$} & \multirow{2}{*}{18} & Deia & 25 & \multirow{2}{*}{$66^{\prime} 4 \mid \mathrm{N}$} \\
\hline & & & $D N A$ & 24 & \\
\hline \multirow{3}{*}{$\begin{array}{l}\mathrm{t} \\
\mathrm{i} \\
\mathrm{c}\end{array}$} & La buida de Younes Abouyaaqoub, & \multirow{2}{*}{22} & Deia & $38-39$ & \multirow{2}{*}{$78^{\prime} 6 \mid \mathrm{N}$} \\
\hline & autor del atropello de La Rambla & & $D N A$ & $18-19$ & \\
\hline & & 24 & Deia & 36 & $73^{\prime} 6 \mid \mathrm{E}$ \\
\hline
\end{tabular}

${ }^{16}$ Koldo Domínguez. "Los imanes sin formación son una bomba de relojería". 


\begin{tabular}{|c|l|l|l|l|c|}
\hline $\mathrm{i}$ & $\begin{array}{l}\text { El recorrido de Abdelbaki Es Satty, } \\
\text { a }\end{array}$ & & DNán de la mezquita de Ripoll & 22 & \\
\cline { 2 - 6 } $\mathrm{s}$ & Atentados en Catalunya & 19 & $\mathrm{NG}$ & 12 & $56,1 \mid \mathrm{S}$ \\
\hline
\end{tabular}

Tabla 5. Fuente: Propia. ${ }^{*} E$ : Excelente. N: Notable. S: Suficiente.

Como puede apreciarse, la calidad de las infografías de EC y $D V$ son más elevadas que las de los diarios del grupo Noticias, quienes entre los tres suman dos infográficos menos que los dos periódicos de Vocento. Así las cosas, cabe destacar que es efectivamente este grupo de información quien más trabaja la infografía, tanto a nivel de calidad como de cantidad.

Sin embargo, en lo que a calidad refiere, las infografías de los diarios de Noticias no desmerecen, siendo cuatro de ellas de notables (Deia 18:25, 22:38-39; DNA 18:24, 22:18-19) y dos excelentes (Deia 24:26, $D N A$ 24:22), habiendo solo una suficiente (NG 19:12). Ninguna de ellas es pues insuficiente, aportando el valor periodístico deseado.

\section{Cantidad infografías Vocento Noticias}

\begin{tabular}{lll} 
Excelentes & 5 & 2 \\
Notables & 2 & 4 \\
Suficientes & 2 & 1 \\
\hline TOTAL & 9 & 7
\end{tabular}

Tabla 6. Cantidad de infografías por evaluación y grupos. Fuente: Propia.

Si se realiza finalmente un diagrama de barras con las medias aritméticas de los índices de calidad obtenidos en la Tabla 5, queda latente que es $E C$, como estaba previsto, el diario que obtiene un mayor índice de calidad en sus infografías, convirtiéndose así en líder en esta disciplina. Y si por fin se realiza otra media aritmética agrupando las cifras obtenidas en los diarios por cada grupo informativo, Vocento obtiene un índice de 77'9, y Noticias de 67'3, dando así a entender que las infografías del primer grupo son excelentes, mientras que los del segundo son notables, de buena calidad, en cualquier caso. 
Valor medio de las infografías analizadas por diarios

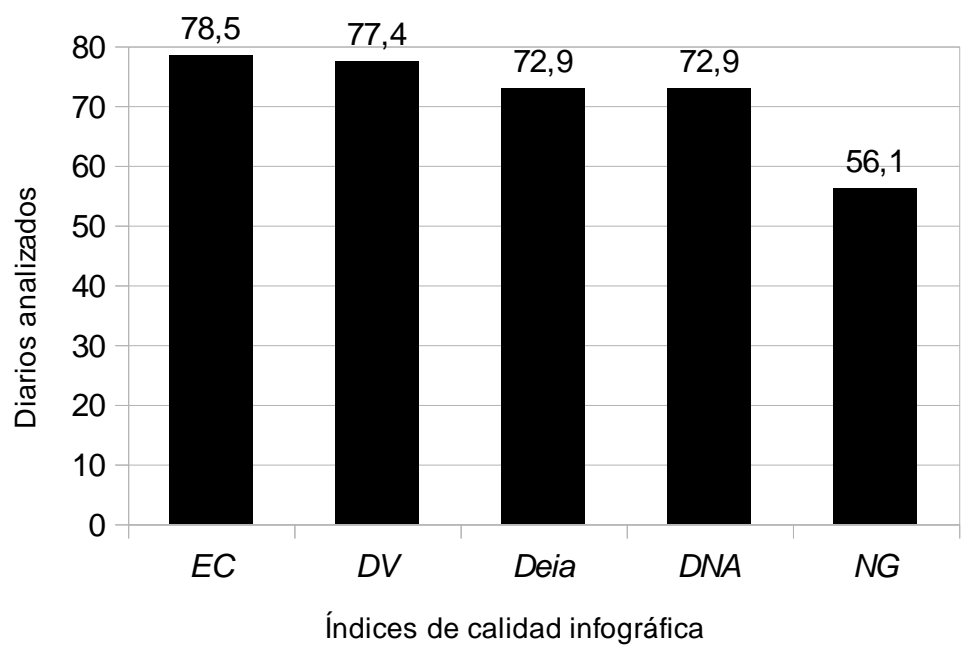

Gráfico 1. Fuente: Propia.

Conviene cerrar este epígrafe nombrando a los autores de las infografías estudiadas, que curiosamente solo pertenecen a Vocento, en tanto que los infografistas de Noticias no firman, al menos en los infográficos aquí estudiados, sus obras. Destacable es pues la firma de Josemi Benítez, quien firma la mayoría de los infográficos de Vocento -EC 18:19, 19:30-31 (DV 19:26-27), 22:28-29 (DV 22:24-25) y 24:35 (DV 24:25) - junto con Izania Ollo -EC 18:19, 19:30-31 (DV 19:2627) y 22:28-29 (DV 22:24-25) - e Isabel Toledo, coautora con los dos anteriores de la infografía del día 22 (EC:28-29; DV:24-25) y única creadora de la del 24 (EC:35; DV:25). Por su parte, Benítez es también único firmante de la megainfografía del día 24 (EC:35; DV:25), también de importante calidad.

\begin{tabular}{|c|c|c|c|c|}
\hline \multirow{2}{*}{ Título infografía } & \multicolumn{3}{|c|}{ Ubicación } & \multirow{2}{*}{ Autor(es) } \\
\hline & Día & Diario & Pág. & \\
\hline Atentado en las Ramblas & 18 & $E C$ & 19 & Benítez, Ollo \\
\hline \multirow{2}{*}{ Lo que se sabe de los atentados } & \multirow{2}{*}{19} & $E C$ & $30-31$ & \multirow{2}{*}{ Benítez, Ollo } \\
\hline & & $D V$ & $26-27$ & \\
\hline \multirow{2}{*}{96 horas de huida a través de Barcelona } & \multirow{2}{*}{22} & $E C$ & $28-29$ & \multirow{2}{*}{$\begin{array}{c}\text { Benítez, Ollo } \\
\text { y Toledo }\end{array}$} \\
\hline & & DV & $24-25$ & \\
\hline \multirow{2}{*}{ Centros de culto islámico en España } & \multirow{2}{*}{23} & $E C$ & 33 & \multirow{2}{*}{ Toledo } \\
\hline & & DV & 28 & \\
\hline \multirow{2}{*}{ Los escenarios } & \multirow{2}{*}{24} & $E C$ & 35 & \multirow{2}{*}{ Benítez } \\
\hline & & DV & 25 & \\
\hline
\end{tabular}

Tabla 7. Créditos de las infografías estudiadas. Fuente: Propia. 


\section{Conclusiones}

Volviendo sobre las hipótesis enunciadas, cabe concluir primeramente que es El Correo, con el mayor número de infografías estudiadas, el diario que más y mejores infográficos ha realizado durante el periodo que se estudia. Los diarios de Vocento, El Correo y Diario V asco, resultan referentes en la Comunidad Autónoma, produciendo infografías de excelente calidad con firmas entre las que destaca Josemi Benítez. También son los que mayor penetración tienen en sus respectivas provincias de difusión, lo que coincide con la calidad de los gráficos aquí analizados.

Por otra parte, los periódicos de Noticias no distan tanto de los anteriores, con infografías de calidad notable. Se percibe pues un marcado interés en éstos por el producto infográfico, que, si bien no llega a la calidad y cantidad de Vocento, pone de manifiesto que este grupo de información cree en la infografía como material periodístico útil. Entre los tres diarios analizados, Deia, Diario de Noticias de Álava y Noticias de Gipurkoa, es este último el que menos infografías ha producido, con una solo a estudio, y de calidad suficiente.

Asimismo, la tipología más frecuente de los infográficos estudiados ha sido la infografía ubicativa, a la contra de la tendencia anteriormente analizada de producción de infografías escénicas para el cubrimiento de información sobre atentados. En el periodo estudiado, los grupos de noticias primaron la identificación de los lugares atacados, produciendo de común infográficos ubicativos y documentales sobre el 17A.

Como conclusión general, debe valorarse que los dos grandes grupos de información en el País Vasco tienen fe en la infografía como medio informativo, y que aquellas que producen destacan una calidad muy apreciable en un territorio de importante cobertura periodística. 


\section{Bibliografía}

Cairo, A. (2008). Infografía 2.0 : visualización de información en prensa. Madrid: Alamut

Chimeno, M. (2015). La eficacia comunicativa de la infografía como mensaje periodístico. Tesis doctoral. Valladolid (España): Universidad de Valladolid.

Colle, R. (2004). "Infografía: tipologías". Revista Latina de Comunicación Social, 58. Recuperado el 20 de octubre de 2017 de http://www.ull.es/publicaciones/latina/latina art660.pdf

De Pablos, J.M. (1998). "Siempre ha habido infografía (3)". Revista Latina de Comunicación Social, 5. Recuperado el 28 de enero de 2003

de http://www.ull.es/publicaciones/latina/a/88depablos.htm

De Sousa, J.M. (2002). Libro de estilo Vocento. Madrid: Vocento

Elorza, A. (ed.) (1995). La patria de los vascos. Sabino Arana Goiri: antología de escritos políticos. San Sebastián (España): Haranburu Editor.

García-González, D. (2012). Kazetaritza infografiaren garapena Espaniako prentsan. "El Correo Español-El Pueblo V asco"-ren kasua. Tesis doctoral. Lejona (España): Universidad del País Vasco. URI: http://hdl.handle.net/10810/11623

Jacob, J.E. (1994). Hills of conflict. Basque Nationalism in France. Reno (Nevada): University of Nevada Press. "Introduction", pp.xiiixix

Leturia, E. (1998). "¿Qué es infografía?". Revista Latina de Comunicación Social, 4. Recuperado el 20 de octubre de 2017 de http://www.ull.es/publicaciones/latina/z8/r4el.htm

Valero, J.L. (2001). La infografía: técnicas, análisis y usos periodísticos. Colección Aldea Global, 9. Barcelona: Universidad Autónoma

Valero, J.L (2009). "La transmisión de conocimiento a través de la infografía digital". Ámbitos, (18), pp.51-63, recuperado el 23 de enero de 2013 de http://grupo.us.es/grehcco/ambitos18/04valero.pdf

Zamarra, M.M. (1996). La Guerra del Golfo en la integración de la infografía en la prensa diaria. Tesis doctoral. Madrid: Universidad Complutense 


\subsection{Otros documentos}

CIES (2016). "Lectores último periodo por títulos. Euskadi", recuperado el 15 de octubre de 2017 de http://ciessl.com/imagenes/13.pdf

Congreso de los Diputados (2003). Constitución Española. Recuperado el 2 de mayo de 2018 de

http://www.congreso.es/consti/constitucion/indice/index.htm

Deia (2017). "Los primeros 40 años de Deia". Editorial, 2 de enero, recuperado el 20 de enero de 2018 de http://www.deia.com/2017/01/02/opinion/editorial/losprimeros-40-anos-de-deia? random $=653811$

El País (2017). "Los fallecidos tras los atentados de Barcelona y Cambrils". Reportaje, 21 de agosto, recuperado el 15 de octubre de 2017 de

https://politica.elpais.com/politica/2017/08/19/actualidad/15 $03144692349410 . \mathrm{html}$

Eustat - Instituto Vasco de Estadística, recuperado el 19 de enero de 2018 de http://www.eustat.eus

Gobierno (Presidencia) (1979). "El Estatuto de Autonomía". Gobierno vasco. Recuperado el 2 de mayo de 2018 de http://www.euskadi.eus/gobiernovasco/contenidos/informacion/estatuto guernica/es 455/esta tu c.html

SER (Cadena) (2017). "Aumenta a 16 el número de fallecidos en los atentados de Cataluña". Noticia, 27 de octubre, recuperada el 15 de octubre de 2017 de http://cadenaser.com/emisora/2017/08/27/radio barcelona/ 1503828606 116148.html

Ymedia (agencia de medios) (2017). $2^{\circ}$ EGM 2017, julio, recuperado el 18 de enero de 2018 de https://goo.gl/JUCeqh 


\section{Infografías estudiadas}

\section{Atentado en las Ramblas}

Josemi Benítez e Izania Ollo (EC 18:19). Documental.

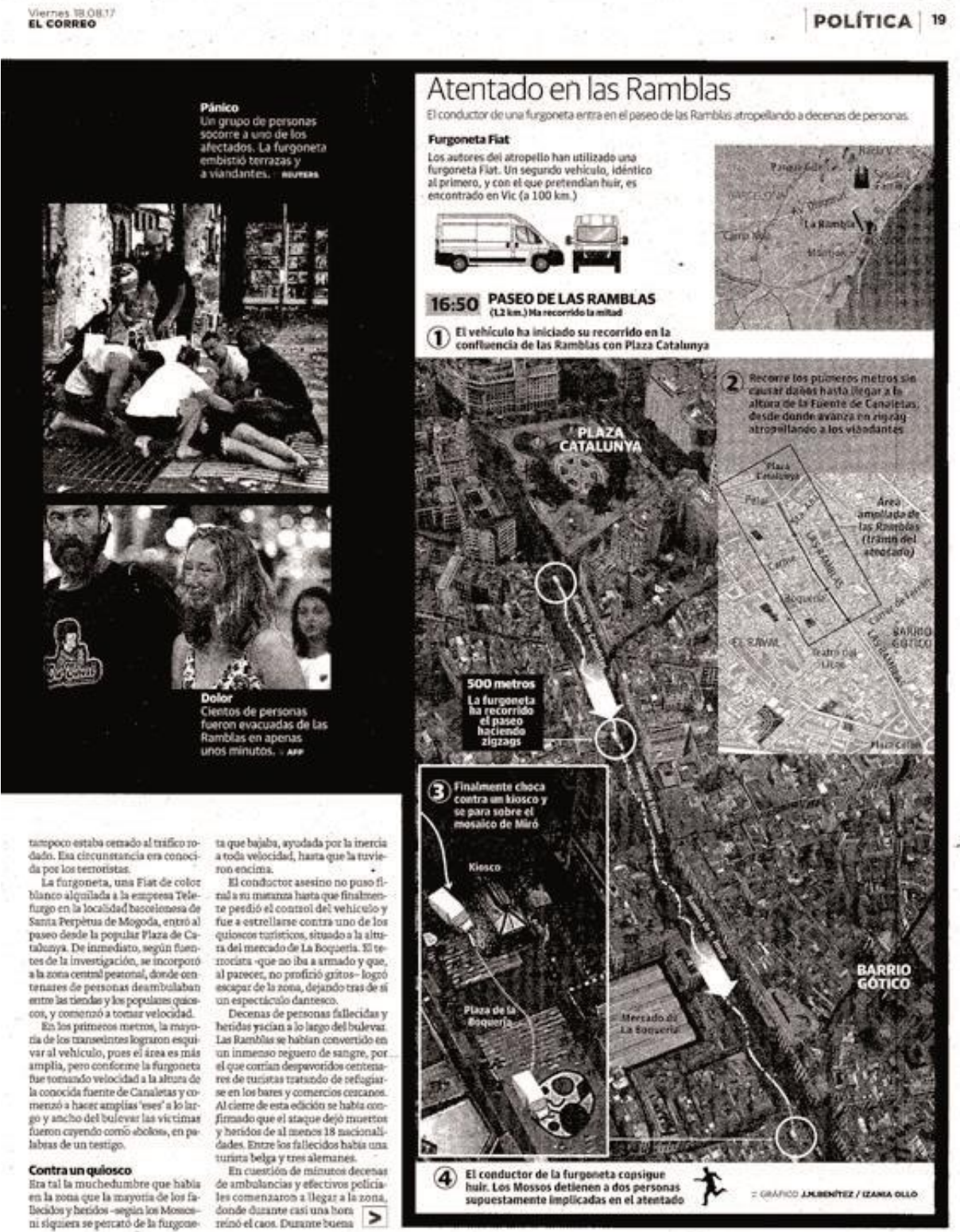

Característica Propiedades Información ¿Qué/Quién(es)? 1 ¿Cuándo? 1 ¿Dónde? 1 ¿Por qué? 1 04'0 Significación Asunto clave 1 Identificación. 1 Familiaridad. 1 Actualidad. $1 \quad 04{ }^{\prime} \mathbf{0}$ Comprensión Visibilidad. 1 Claridad. 1 Legibilidad. 1 Didactismo. $1 \quad \mathbf{0 4} \mathbf{0}$ Estética Detalles a mano. 0 Dinamismo. 1 


\section{"Gracias". 1 Originalidad. $0 \quad 02$ '0}

Iconicidad Abstracción. $\mathbf{0}$ Figuras en perspectiva. $\mathbf{0}$

Figura

Plana. 1 Fotografías. $\mathbf{0} \quad \mathbf{0 1} \mathbf{0}$

Tipografía Titulo. 1 Texto explicativo. 1

Crédito. 1

Rótulos. $1 \quad \mathbf{0 4} \mathbf{0}$

Funcionalidad Sintesis .1 Proporción información. 0'6

Complemento. 0 Proporción página. $\mathbf{0}^{\prime} 2 \quad \mathbf{0 1}^{\prime} 2$

TOTAL: $\quad 23 ' 2$

$$
23^{\prime} 2 \cdot 100 / 28=\quad 82^{\prime} 9
$$

\section{Calificación: EXCELENTE}

\section{Lo que se sabe de los atentados}

Josemi Benítez e Izania Ollo (día 19, EC:30-31; DV:26-27). Escénica.

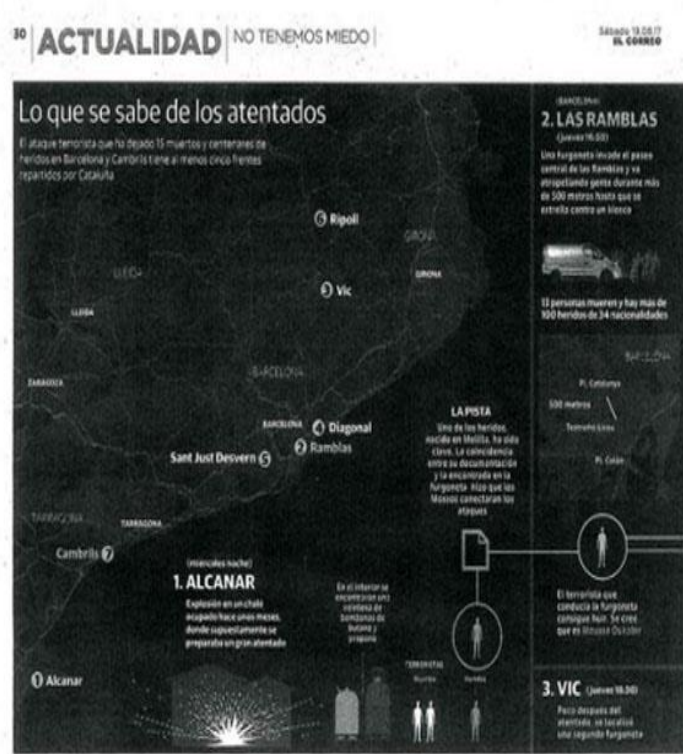

kecomon

| POLITICA |

Los terroristas planeaban la mayor cadena de atentados del yihadismo en Europa
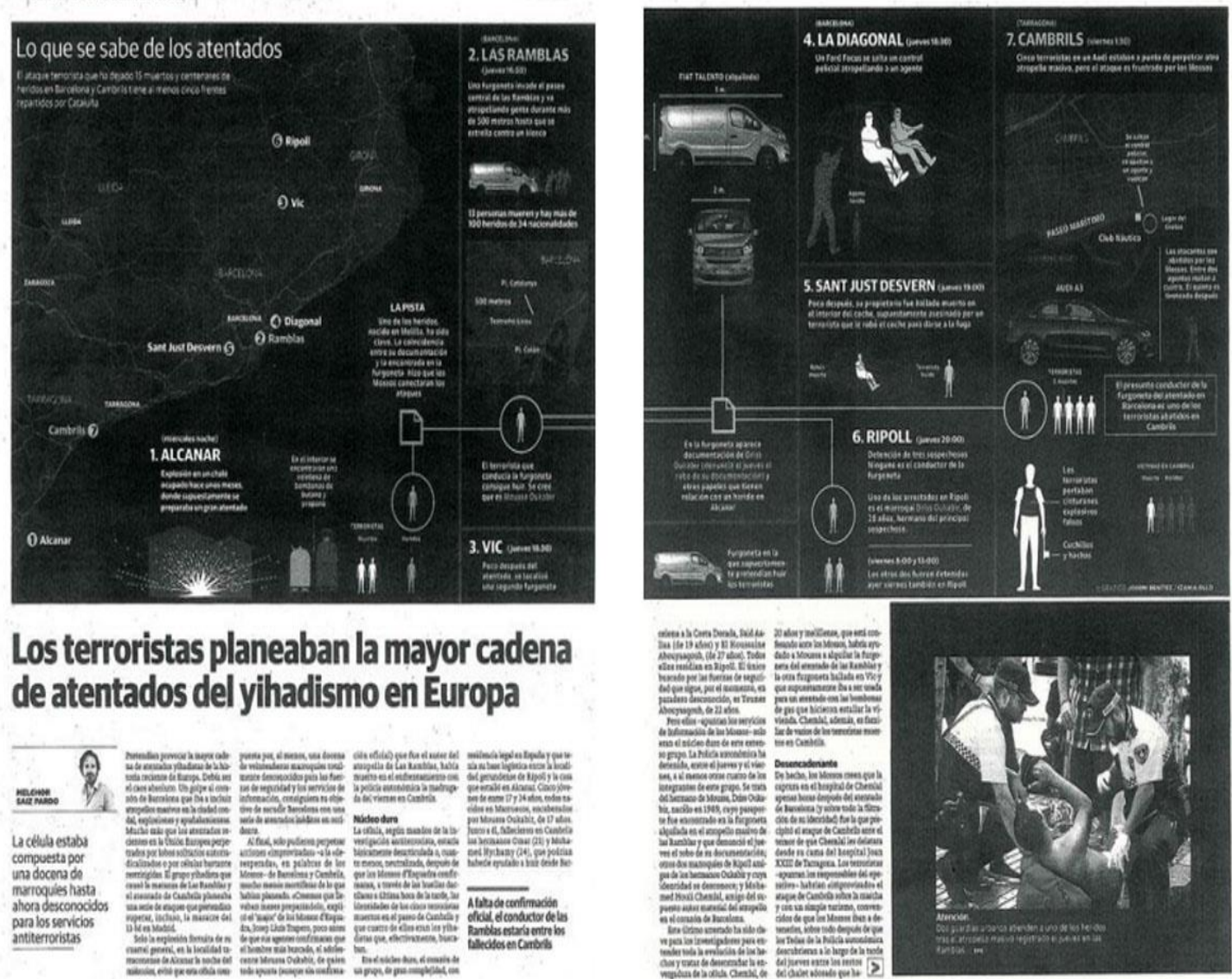

Característica Propiedades

Total

Información ¿Qué/Quién(es)? 1 ¿Cuándo? 1

¿Dónde? 1 ¿Por qué? $1 \quad 04$ '0

Significación Asunto clave. 1 Identificación. 1 
Familiaridad. 1 Actualidad. $1 \quad$ 04'0

Comprensión Visibilidad. 1 Claridad. 1

Legibilidad. 1 Didactismo. $1 \quad 04{ }^{\prime} \mathbf{0}$

Estética Detalles a mano. 0 Dinamismo. 1

"Gracias". 0 Originalidad. 0 01'0

Iconicidad Abstracción.1 Figuras en perspectiva. 1

Plana. 1 Fotografías. $1 \quad \mathbf{0 4} \mathbf{0}$

Tipografía Titulo. $1 \quad$ Texto explicativo. 1

Figura

Rótulos. $1 \quad 04 \mathbf{4}^{\mathbf{0}}$

Funcionalidad [Máximo valor por ser megainfografía] $\quad \mathbf{0 4}^{\prime} \mathbf{0}$

TOTAL: $\quad 25^{\prime} 0$

$$
25 \cdot 100 / 28=\quad 89 ' 3
$$

\section{Calificación: EXCELENTE}

\section{6 horas de huida a través de Barcelona}

Josemi Benítez, Isabel Toledo e Izania Ollo (día 22, EC:28-29; DV:24-25).

Documental.

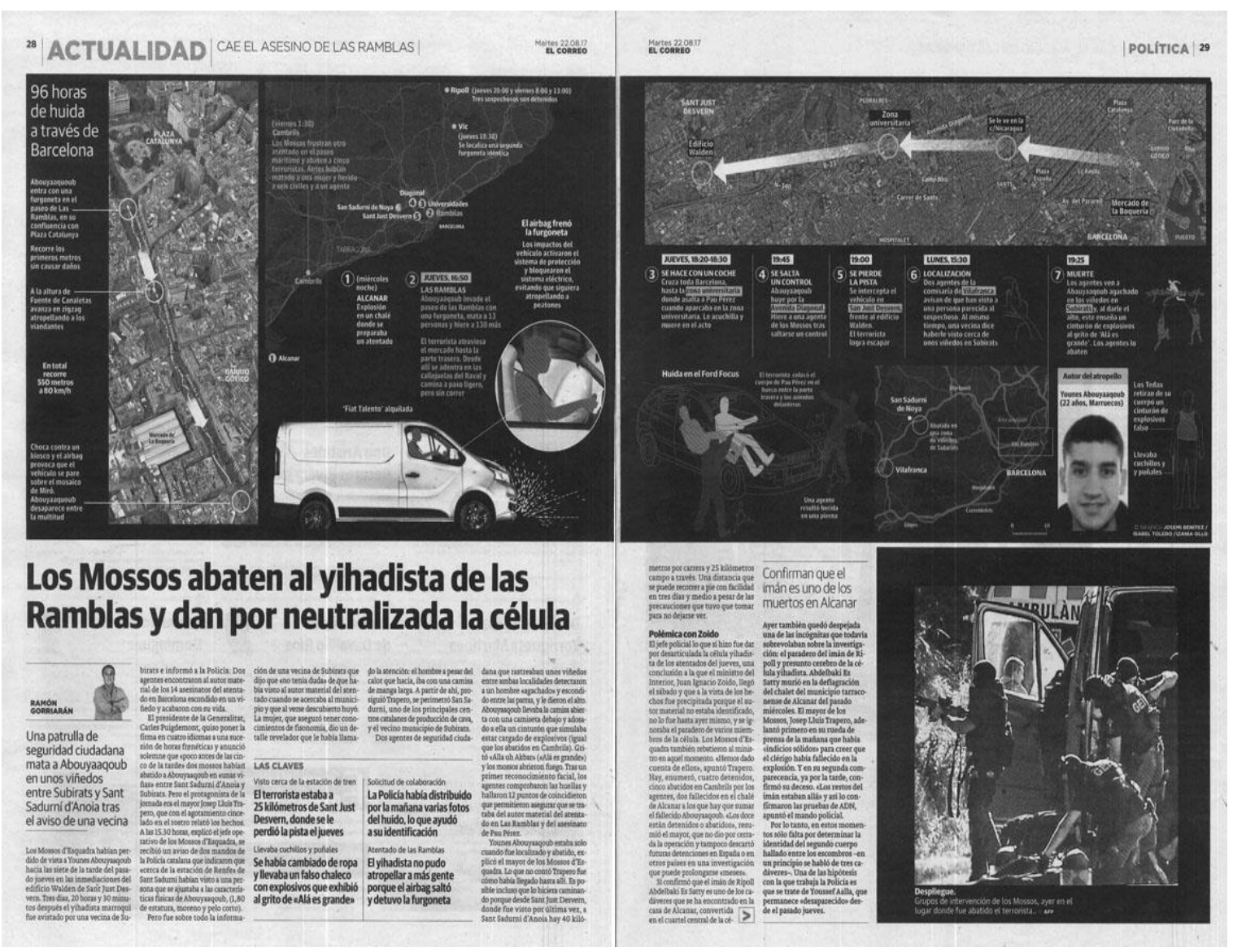


Característica Propiedades

Total

Información ¿Qué/Quién(es)? 1 ¿Cuándo? 1

¿Dónde? 1 ¿Por qué? $1 \quad$ 04'0

Significación Asunto clave. 1 Identificación. 1

Familiaridad. 1 Actualidad. $1 \quad 044^{\prime} 0$

Comprensión Visibilidad. 1 Claridad. 1

Legibilidad. 1 Didactismo. $1 \quad \mathbf{0 4} \mathbf{0}$

Estética Detalles a mano. 0 Dinamismo. 1

"Gracias". 1 Originalidad. $1 \quad 03$ '0

Iconicidad Abstracción. 0 Figuras en perspectiva. 1

Plana. 1 Fotografías. $\mathbf{0 3} \mathbf{0 3}$

Tipografía Titulo. 1 Texto explicativo. 1

Figura

Rótulos. $1 \quad 04$ '0

Funcionalidad [Máximo valor por ser megainfografía]

TOTAL: $\quad 26^{\prime} 0$

$26 \cdot 100 / 28=92^{\prime} 9$

Calificación: EXCELENTE

Centros de culto islámico en España

Isabel Toledo (día 23, EC:33; DV:28). Ubicativa.

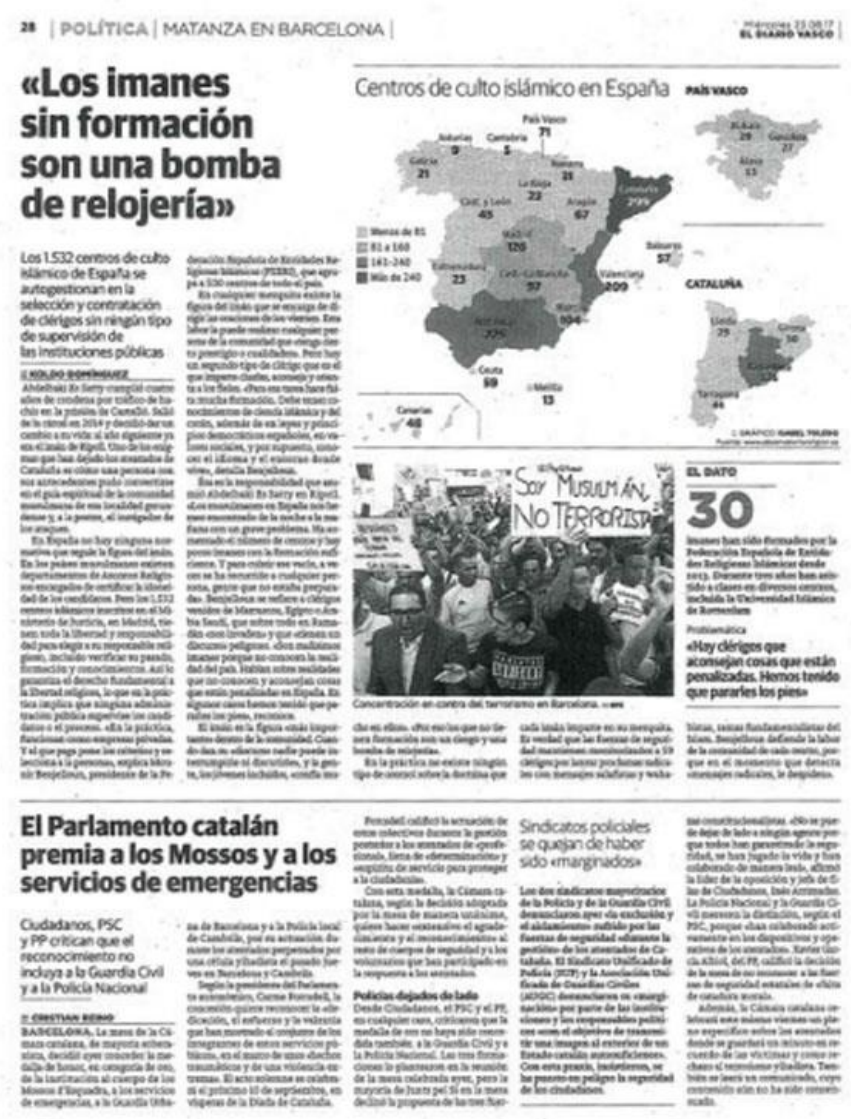


Característica Propiedades

Total

Información ¿Qué/Quién(es)? 1 ¿Cuándo? 0

¿Dónde? 1 iPor qué? 0 02'0

Significación Asunto clave. 1 Identificación. 1

Familiaridad. 1 Actualidad. $1 \quad \mathbf{0 4}^{\prime} \mathbf{0}$

Comprensión Visibilidad. 1 Claridad. 1

Legibilidad. 1 Didactismo. $1 \quad$ 04'0

Estética Detalles a mano. 0 Dinamismo. 0

"Gracias". 0 Originalidad. $0 \quad \mathbf{0 0} \mathbf{0}$

Iconicidad Abstracción. 0 Figuras en perspectiva. 0

Figura

Plana. 1 Fotografías. $0 \quad$ 01'0

Tipografía Titulo. 1 Texto explicativo. 1

Crédito. 1 Rótulos. $1 \quad 04{ }^{\prime} \mathbf{0}$

Funcionalidad Sintesis . 0 Proporción información. 0'3

Complemento. 1 Proporción página. 0'3 $\quad 01^{\prime} 6$

TOTAL: $\quad 16 ' 6$

$16^{\prime} 6 \cdot 100 / 28=\quad 59^{\prime} 3$

\section{Calificación: SUFICIENTE}

\section{Los escenarios}

Josemi Benítez (día 24, EC:35; DV:25). Ubicativa.

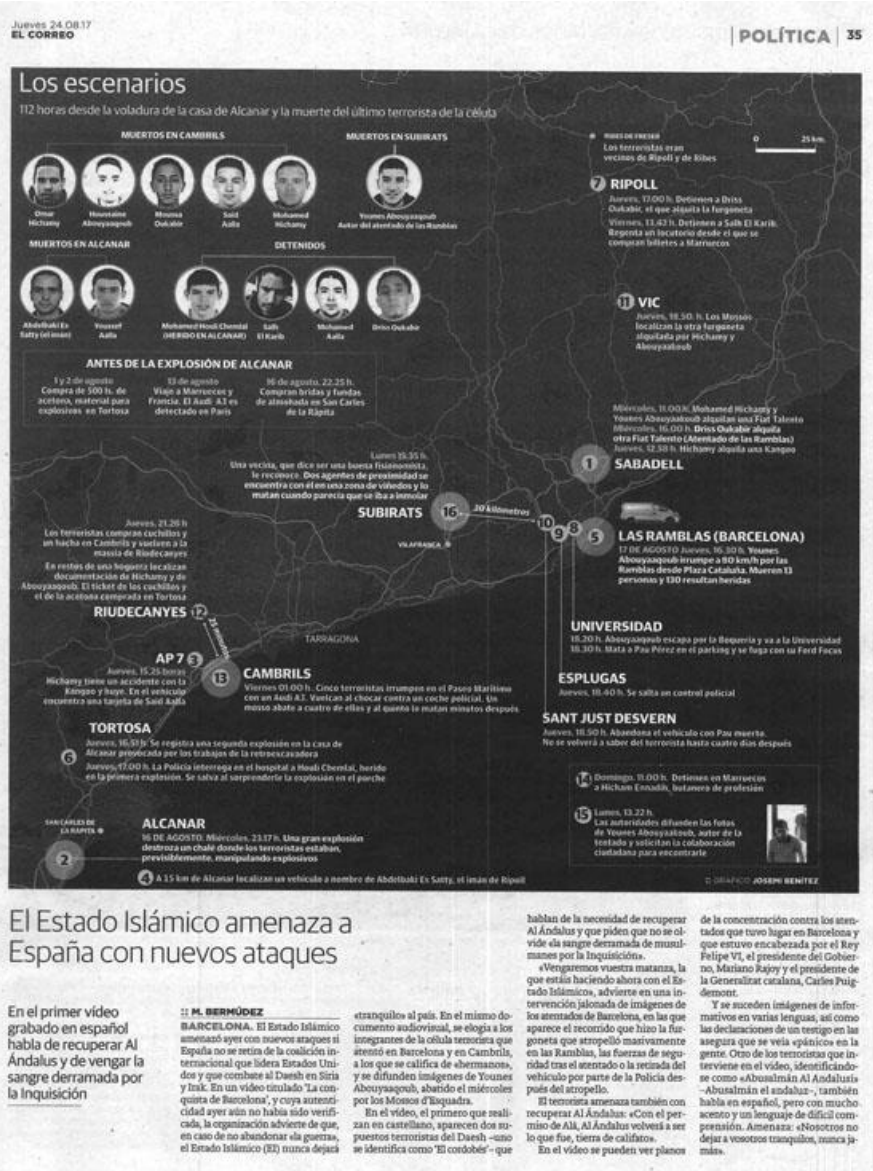


Característica Propiedades Total

Información ¿Qué/Quién(es)? 1 ¿Cuándo? 1 ¿Dónde? 1 ¿Por qué? $1 \quad 04$ '0

Significación Asunto clave. 1 Identificación. 1

Familiaridad. 1 Actualidad. $1 \quad 04$ '0

Comprensión Visibilidad. 1 Claridad. 1

Legibilidad. 1 Didactismo. $1 \quad$ 04'0

Estética Detalles a mano. 0 Dinamismo. 0

"Gracias". 0 Originalidad. 0 00'0

Iconicidad Abstracción. 0 Figuras en perspectiva. 0

Figura

Plana. 1 Fotografías. $1 \quad 02 ' \mathbf{0}$

Tipografía Titulo. 1 Texto explicativo. 1

Crédito. 1 Rótulos. $1 \quad 04^{\prime} \mathbf{0}$

Funcionalidad [Máximo valor por ser megainfografía] $\quad \mathbf{0 4}^{\prime} \mathbf{0}$

TOTAL: $\quad 19^{\prime} 0$

$19 \cdot 100 / 28=67^{\prime} 9$

Calificación: NOTABLE

Itinerario de los atacantes de Barcelona

Día 18 (Deia:25; DNA:24). Ubicativa.

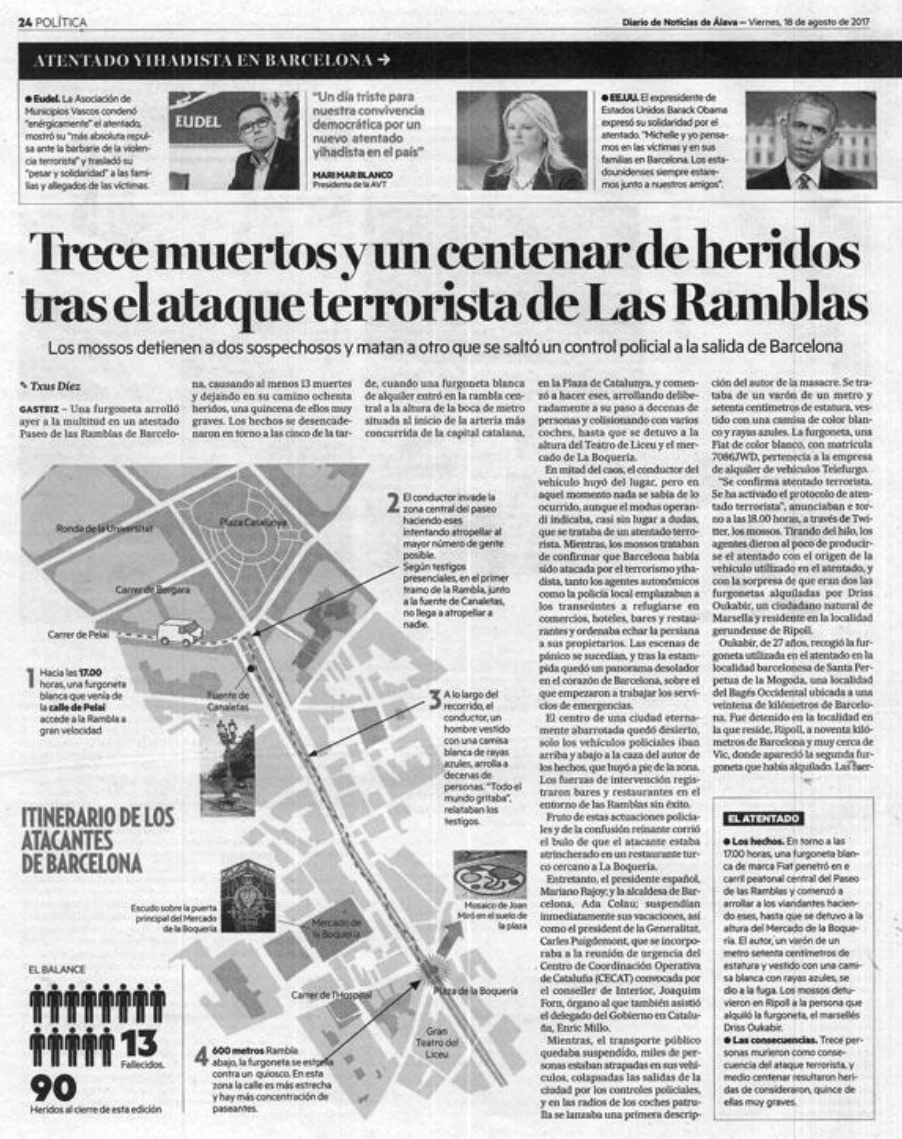


Característica Propiedades

Total

Información ¿Qué/Quién(es)? 1 ¿Cuándo? 1

¿Dónde? 1 ¿Por qué? $1 \quad 04$ '0

Significación Asunto clave 1 Identificación. 1

Familiaridad. 1 Actualidad. $1 \quad 04{ }^{\prime} 0$

Comprensión Visibilidad. 1 Claridad. 1

Legibilidad. 1 Didactismo. $1 \quad \mathbf{0 4} \mathbf{0}$

Estética Detalles a mano. 0 Dinamismo. 0

"Gracias". 0 Originalidad. 0 00'0

Iconicidad Abstracción. 0 Figuras en perspectiva. 0

Figura

Plana. 1 Fotografías. $1 \quad \mathbf{0 2} \mathbf{0}$

Tipografía Titulo. 1 Texto explicativo. 1

Crédito. 0

Rótulos. $1 \quad 03 \mathbf{3}^{\prime} \mathbf{0}$

Funcionalidad Sintesis .1 Proporción información. 0'3

Complemento. 0 Proporción página. 0'3 $\quad 01^{\prime} 6$

TOTAL: $\quad 18^{\prime} 6$

$18^{\prime} 6 \cdot 100 / 28=66^{\prime} 4$

\section{Calificación: NOTABLE}

La huida de Younes Abouyaaqoub, autor del atropello de La Rambla

Día 22 (Deia:38-39; DNA:18-19). Ubicativa.

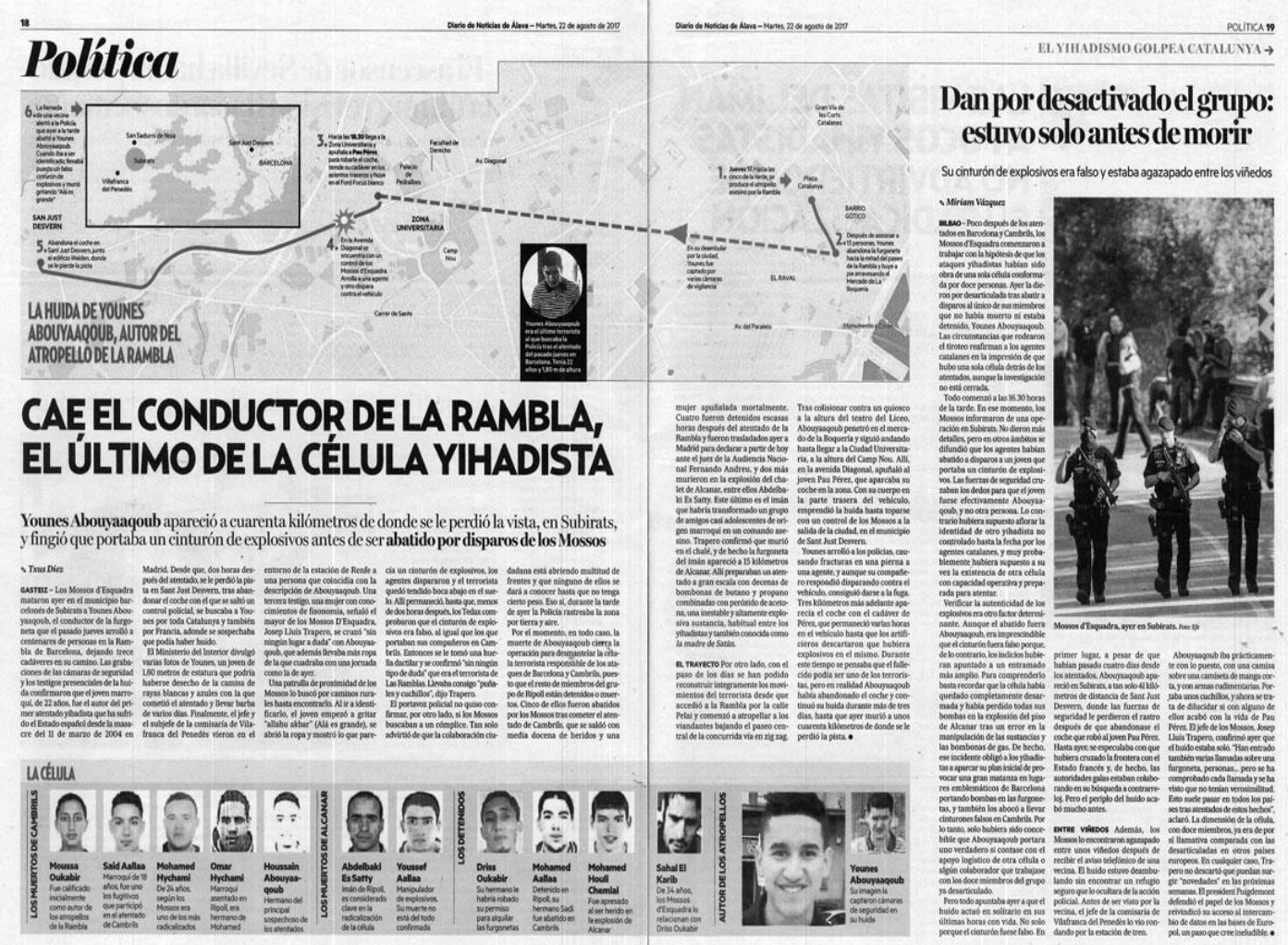


Característica Propiedades Total

Información ¿Qué/Quién(es)? 1 ¿Cuándo? 1 ¿Dónde? 1 ¿Por qué? $1 \quad 04$ '0

Significación Asunto clave. 1 Identificación. 1

Familiaridad. 1 Actualidad. $1 \quad 04$ '0

Comprensión Visibilidad. 1 Claridad. 1 Legibilidad. 1 Didactismo. $1 \quad$ 04'0

Estética Detalles a mano. 0 Dinamismo. 0 "Gracias". 1 Originalidad. 0 01'0

Iconicidad Abstracción. 0 Figuras en perspectiva. 0 Figura

Plana. 1 Fotografías. $1 \quad \mathbf{0 2} \mathbf{0}$

Tipografía Titulo. 1 Texto explicativo. 1

Crédito. 0 Rótulos. $1 \quad$ 03'0

Funcionalidad [Máximo valor por ser megainfografía] $\quad \mathbf{0 4}^{\prime} \mathbf{0}$

TOTAL: $\quad 22^{\prime} 0$

$22 \cdot 100 / 28=78^{\prime} 6$

\section{Calificación: EXCELENTE}

El recorrido de Abdelbaki Es Satty, imán de la mezquita de Ripoll

Día 24 (Deia:36; DNA:22). Ubicativa.

\section{Política}

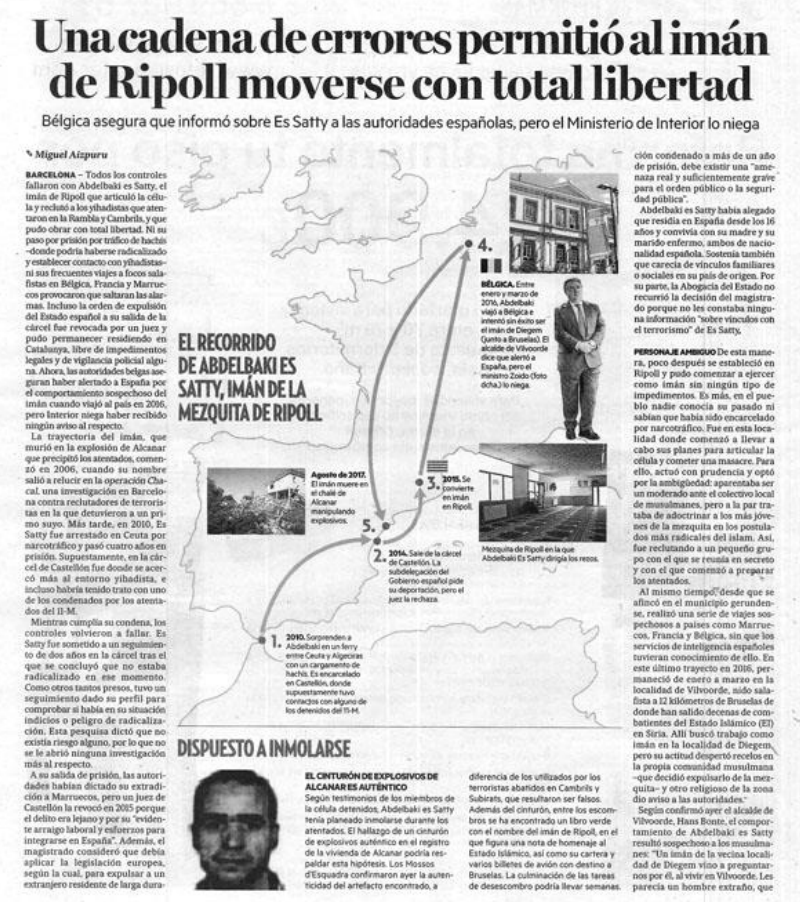


Característica Propiedades

Total

Información ¿Qué/Quién(es)? 1 ¿Cuándo? 1

¿Dónde? 1 ¿Por qué? $1 \quad 04$ '0

Significación Asunto clave 1 Identificación. 1

Familiaridad. 1 Actualidad. $1 \quad 04{ }^{\prime} 0$

Comprensión Visibilidad. 1 Claridad. 1

Legibilidad. 1 Didactismo. 1 04'0

Estética Detalles a mano. 0 Dinamismo. 1

"Gracias". 1 Originalidad. 0 02'0

Iconicidad Abstracción. $\mathbf{0}$ Figuras en perspectiva. 0

Figura

Plana. 1 Fotografías. $1 \quad 02 \mathbf{2}^{\mathbf{0}}$

Tipografía Titulo. 1 Texto explicativo. 1

Crédito. 0

Rótulos. 1 03'0

Funcionalidad Sintesis . 1 Proporción información. 0'3

Complemento. 0 Proporción página. 0'3 01'6

TOTAL: $\quad 20^{\prime} 6$

$20^{\prime} 6 \cdot 100 / 28=\quad 73^{\prime} 6$

Calificación: EXCELENTE

Atentados en Catalunya

NG 19:12. Documental.

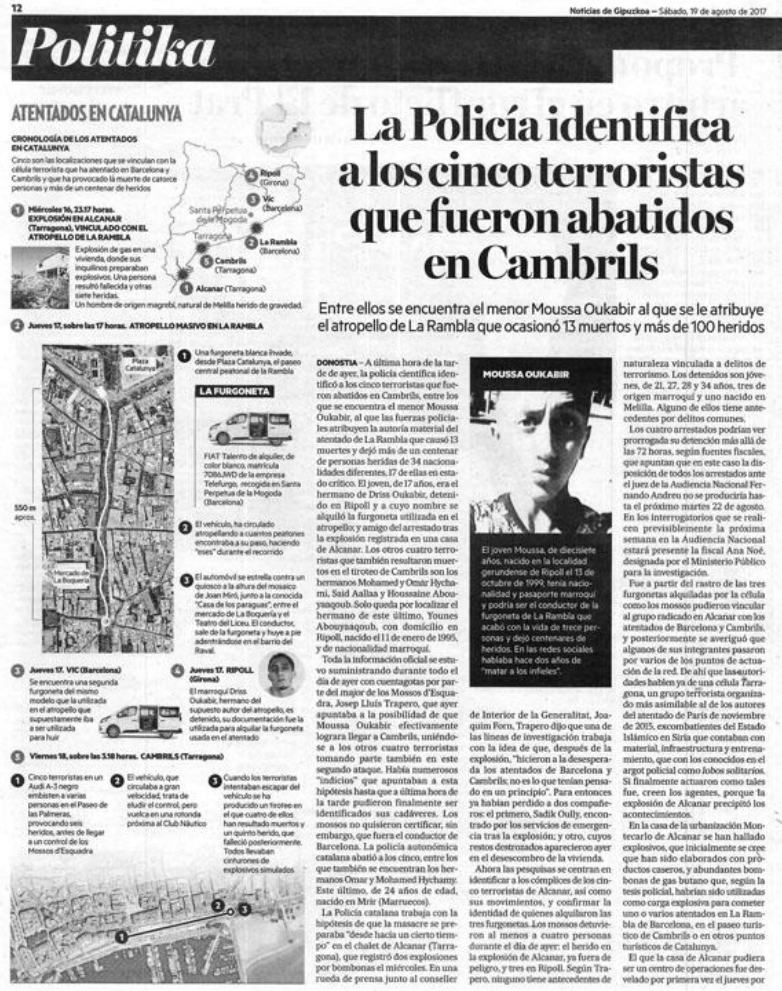


Característica Propiedades Total

Información ¿Qué/Quién(es)? 1 ¿Cuándo? 1 ¿Dónde? 1 ¿Por qué? $1 \quad$ 04'0

Significación Asunto clave. 1 Identificación. 1

Familiaridad. 1 Actualidad. 1

$04{ }^{\prime} 0$

Comprensión Visibilidad. 1 Claridad. 0

Legibilidad. $\mathbf{0}$ Didactismo. $\mathbf{0} \quad \mathbf{0 1} \mathbf{0}$

Estética Detalles a mano. 0 Dinamismo. 0

"Gracias". 0 Originalidad. 0 00'0

Iconicidad Abstracción. 0 Figuras en perspectiva. 0

Figura

Plana. 1 Fotografías. $1 \quad 02 ' 0$

Tipografía Titulo. 1 Texto explicativo. 1

Crédito. 0 Rótulos. $1 \quad 03^{\prime} \mathbf{0}$

Funcionalidad Sintesis . 1 Proporción información. 0'3

Complemento. 0 Proporción páaina. 0'4 $0 \mathbf{0 1}^{\prime} 7$

TOTAL: $\quad 15^{\prime} 7$

$20^{\prime} 6 \cdot 100 / 28=56^{\prime} 1$

Calificación: SUFICIENTE 



\title{
Infografías y visualizaciones
}

\section{Estrategia informativa y formativa en los museos $^{17}$}

\author{
Beatriz Elena Marín-Ochoa ( $(\mathcal{G})$. \\ Facultad de Comunicación Social - Periodismo, \\ GI Comunicación Urbana. UPB, Colombia. \\ beatrize.marin@upb.edu.co \\ Hernán Franco Higuita (๑) \\ Facultad de Diseño Gráfico. UPB, Colombia. \\ hernan.franco@upb.edu.co
}

Resumen: El periodismo científico siempre ha tenido en medios de comunicación y en particular en sus formas narrativas aliados incondicionales para contar el desarrollo de los avances científicos en el mundo, en el país, en las instituciones educación superior o universidades... Por eso, desde su aparición en medios, la infografía y la visualización de datos se aprovechan gracias a sus características como piezas comunicacionales que no solo son herramientas informativas, sino también formativas de forma impresa, audiovisual y digital en pequeño y en gran formato, como estrategia divulgativa o incluso de entretenimiento.

\footnotetext{
${ }^{17}$ Reflexiones en el marco del proyecto de investigación de la Maestría en Diseño y Creación Interactiva de la Universidad de Caldas (Manizales, Colombia) titulado Estudio y proyecto de visualización de información para la comunicación de la ciencia en los museos de ciencia, elaborado por el estudiante diseñador Hernán Franco Higuita y dirigido por la doctora Beatriz Elena Marín Ochoa.
} 
Los museos no son ajenos a ello y es así como en su tarea de atrapar los visitantes en ese mundo sorprendente de colecciones, presentan miles de posibilidades, que por medio de la infografía y la visualización de datos cada vez más proponen un lenguaje y un mensaje que conjuga su verdadero objetivo, que es facilitar la apropiación del patrimonio de una comunidad para fortalecer así su acervo cultural.

Sus particulares facilitan la asociación y la comprensión de las propuestas que su valor cultural proponen y nos recuerdan el valor de transmisión alternativa de conocimiento, porque la infografía y la visualización de datos facilitan la adquisición de aprendizajes por parte de las personas.

Palabras-clave: Infografía, visualización de datos, periodismo científico, divulgación científica, museos.

\section{De árboles, clasificaciones y metáforas}

$\mathrm{D}$ ESDE su origen, el ser humano busca de diferentes maneras comprenderse a sí mismo y a la realidad que lo rodea. Y encontró en la representación gráfica la mejor forma de expresar sus hallazgos. La ciencia no es ajena a ello y es así como encontramos experiencias de todo tipo como por ejemplo en la historia de la biología, se encuentra una antigua representación llamada La gran cadena del ser que muestra los seres del mundo organizados de arriba hacia abajo: en la parte más alta se encuentra Dios y debajo de él los ángeles, la humanidad, los animales, las plantas y los minerales. Esta clasificación se basa en la ontología de Aristóteles, que catalogaba lo conocido por el ser humano en categorías opuestas. Años más tarde, este concepto tomó la forma de una estructura arborescente conocida como el Árbol de Porfirio, considerado el árbol del conocimiento más primitivo (Lima, 2015). 


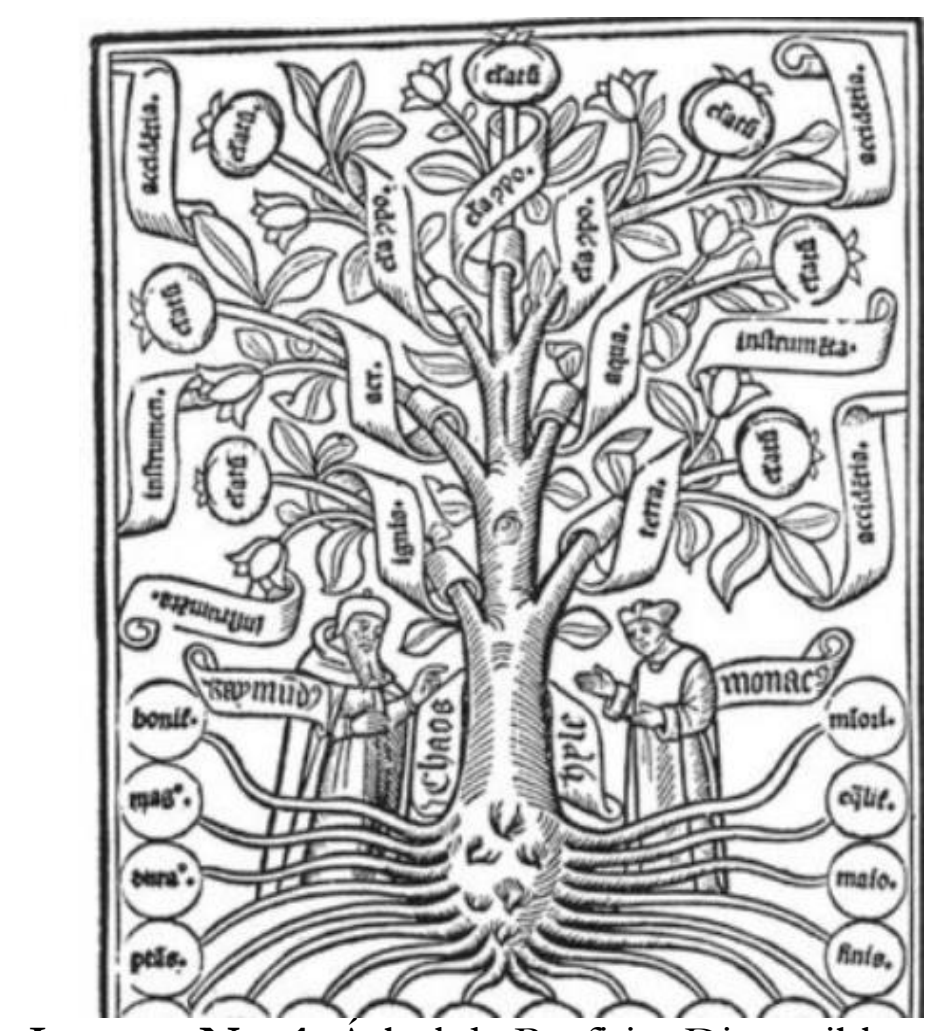

Imagen No. 1. Árbol de Porfirio. Disponible en: https://www.lifeder.com/arbol-porfirio/

Los esquemas ramificados o mapas de árbol son metáforas de la naturaleza representadas de manera visual para comunicar todo tipo de información que con el tiempo se convirtieron en una poderosa herramienta de comunicación para mapear diferentes tipos de conocimientos. De ahí que encontramos los mapas de la moral (árbol de virtudes y árbol de vicios) utilizados en la tradición cristiana medieval para mostrar de manera paralela las relaciones entre las virtudes y los vicios del ser humano; y los mapas de consanguinidad (árboles genealógicos) que tanto aportaron a la comprensión de la genética y que muestran los diferentes lazos de sangre entre los integrantes de la gran familia.

Esta estructura visual es considerada el arquetipo de estos diagramas. Estas formas de mapear información son consideradas las primeras explicaciones diagramáticas en forma de árbol de la historia, y tiene su origen en la alta Edad media (segunda mitad del siglo I) cuando aparece la metáfora científica que hemos visto en enciclopedias y textos de biología como los mapas o árboles de especies, imágenes que son una manera eficaz de graficar la información porque representan ese deseo 
del ser humano por el orden, la simetría, el equilibrio y la unidad (Lima, 2015).

El uso de visualizaciones de información en medios de comunicación, revistas, libros, web, dispositivos móviles, incluso en espacios de conocimiento como planetarios, parques científicos y museos, es cada vez más popular. Desde la década de los noventa y en los últimos lustros tomó fuerza una nueva forma de comunicación (Marín, 2010; Valero, 2010) que permite visualizar y presentar los desarrollos y resultados científicos al público para facilitarle su acceso, interacción, análisis, asociación y comprensión: la infografía y la visualización de datos.

Uno de los aspectos más importantes y que se tiene como objetivo último en el proceso de investigación, transferencia e innovación es la divulgación de resultados, ejercicio de comunicación de la ciencia que permite llevar el conocimiento científico a realidades sociales concretas a través de la práctica, con la idea de mejorar aspectos de la vida diaria y productiva de las empresas y la sociedad, para favorecer los alcances de esta forma de presentación informativa.

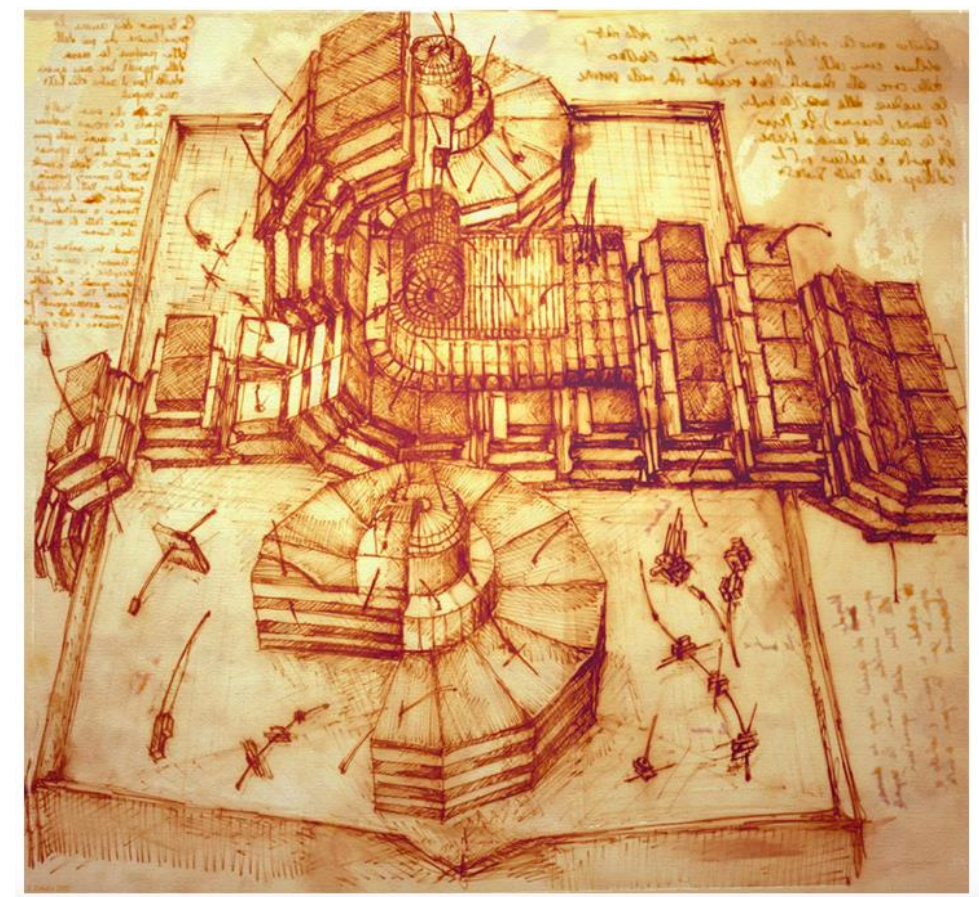

Imagen No. 2. Invención de Leonardo Da Vinci. Disponible en: http://revistafeel.com.mx/feel-lifestyle/leonardo-da-vinci-precursor-de-lasciencias/\# 
Algunos autores han mencionado que el siglo XX pasará a la historia por haber dado su lugar de importancia a la divulgación de la ciencia y el conocimiento a través del periodismo. Como ya habíamos mencionado al comienzo un ejemplo de divulgador es Leonardo da Vinci quien llamaba la atención a los científicos de que su primer deber era contar lo que hacían a la sociedad.

Igual ejemplo fue Carda, Voltaire, Flammarion y Verne, quien detrás de sus textos de ciencia ficción no solo se adelantó a sus tiempos, sino que fueron divulgadores muy apreciados por los lectores de medios. Y en España se dice que en 1923 con la llegada de Einstein se abrio la posibilidad de hablar sobre ciencia en universidades, sociedades cientificas y periódicas.

El 9 de marzo de 1923, en la Residencia de Estudiantes, Ortega presenta a Einstein como «una de las más gloriosas fisonomias de la bistoria bumana». Las lecciones del cientifico en España tuvieron la virtud de acercar la ciencia al público, aunque no su comprensión, naturalmente. Todos hablan de la relatividady del físico artista, la prensa llena columnas y columnas, los dibujantes derrochan donaire y buen humor... Ortega y Gasset contó en La Nación de Buenos Aires que en Toledo, al ser Einstein reconocido, la gente se arremolinaba en la plaza de Zocodo. (Calvo, 2002:16).

El periodismo científico, desde mediados del siglo $\mathrm{XX}$, dedica esfuerzos a comunicar temas de la ciencia a través de artículos publicados en revistas, periódicos y suplementos, y descubrio en la infografía y la visualización de datos una manera de facilitar el acceso del lector a los contenidos científicos. Valero (2010) nos recuerda el caso del ingeniero Emilio Novoa, que en el suplemento dominical Blanco y Negro del periódico ABC (España), utilizaba dibujos hechos a mano para explicar fenómenos y temas difíciles de comprender para acompañar sus artículos periodísticos.

Otro caso destacado es la serie de televisión The Mechanical Universe (1987), donde el científico informático estadounidense Jim Blinn utilizaba imágenes reales (fotografías satelitales) con imágenes sintéticas (graficadas por computador) para explicar conceptos de física. Esta forma de representación visual se convirtió en un 
instrumento de visualización de información para los científicos y los técnicos, además acercó la astronomía al espectador del común.

\section{De Comunicación científica a apropiación del conocimiento}

La ciencia, a lo largo de su historia, utilizó todo tipo de imágenes para ilustrar, explicar, sintetizar y mostrar aspectos complejos de sus prácticas y de sus teorías. En la época del Renacimiento, la obra “De bumani corporis fabrica" de Andreas Vesalius enseñó que, mediante la disección de cadáveres, se podía reproducir de manera fiel en ilustraciones cada una de las partes de la anatomía humana. Vesalius, siendo profesor de la escuela de Padua y basado en objetivos pedagógicos "compuso su Estudio en siete libros, en los que se explica la estructura y las funciones anatómicas, así como la manera de efectuar una correcta disección” (Rodríguez, 2013: 1013).

Entonces la anatomía que se estudiaba era la de Galeno, y por eso se le denominaba galénica y se basaba en disecciones animales, Vesalius identificó los errores de los textos y argumentó sus propuestas ante profesores de anatomía, incluido su maestro Jacques du Bois, conocido como Sylvius. Vesalius hizo de la anatomía una disciplina empírica, este es su mayor contribución a la ciencia, a pesar de las controversias generadas:

$V$ esalio, impertérrito, continuó provocando controversias, esta vez no demostrando los errores de Galeno, sino de Mondino de Liuzzi, e incluso de Aristóteles: los tres habian hecho suposiciones acerca de las funciones $y$ estructura del corazón que eran claramente erróneas. Por ejemplo, Vesalio descubrió que el corazón tenía cuatro cavidades, que el hígado tenía dos lóbulos y que los vasos sanguineos comenzaban en el corazón, y no en el bigado. (Romero, 2007, sp.) 


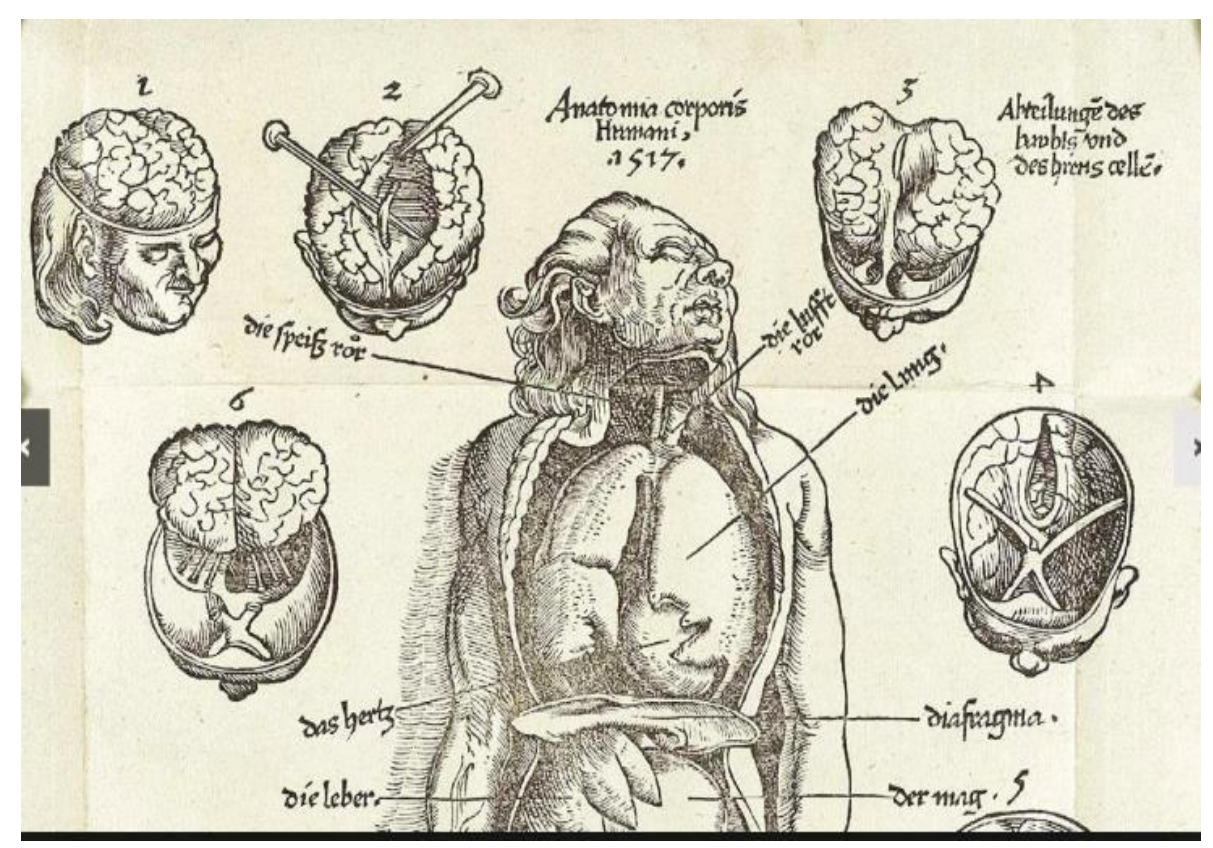

Imagen No. 3. Primeras aproximaciones al cerebro humano del anatomista holandés Andreas Vesalius. Disponible en: http://widgetserver.com

Leonardo Da Vinci, otro ejemplo clásico de esta época, realizó ilustraciones explicativas de las partes del cuerpo humano y de los artefactos que inventaba. Se considera que las ilustraciones de Da Vinci son una mezcla entre ciencia y técnica, en especial las publicadas en los códices Madrid I y Madrid II (CMEditores, sf).

Entre sus aportes se incluyen máquinas de guerra como: el tirador gigante, la catapulta múltiple tipo honda o los puentes móviles; maquinaria civil como la bomba hidraúlica doble, el perspectógrafo o la grúa rotativa; aportó también a la arquitectura y la geometría con su castillo de planta cuadrad, su estudio de muro enrejado de jardín o su cuadratura de superficies curvas; y en vuelo y movimiento podemos destacar: alas mecánicas, estudios de máquina voladora y ballesta de repetición gigante.

Sobre el estudio de Alas mecánicas, folio 844r, dice Navoni:

Este folio contiene un nuevo estudio para la construcción de unas alas mecánicas a partir de un análisis preciso de la anatomía de los pájaros: las leyendas del margen superior derecho, situada justo debajo de un pequeño diagrama esquemático de un ala, parece aludir a esto, ya que reza: "disección de un pájaro". Entre otras cosas, aqui observemos como en otros casos, 
Leonardo utiliza un sistema criptográfico escribiendo una palabra invertida. (2012: 186).

Este legado de arte y ciencia de Miguel Ángel hoy es reconocido gracias a la publicación del Códice Atlántico, que incluyo 100 de los originales suyos, y que nos acerca a otra forma de ordenar el legado de uno de lo mas grandes artistas de la humanidad y que hoy se conserva en la biblioteca Ambrosiana de Milán.

Y hacia finales del siglo XVII, el científico Robert Hooke ilustra a escala mayor insectos y otros organismos observados a través del microscopio. Para Rodríguez "la estandarización visual de los objetos contribuyó al desarrollo de la historia natural al hacer posible la difusión de datos en las comunidades de científicos" (2013: 1016), y añade:

Los dibujos que trazaron durante las exploraciones (durante la Colonia) [...] fueron eficaces porque representaron una noción de la realidad que no se lograba preservar en el herbario seco ni por medio de los ejemplares de animales disecados preparados por los taxidermistas.

Rodríguez destaca que la ilustración científica estuvo presente no solo en los científicos, sino también en las publicaciones periódicas de divulgación científica. De igual forma, en los textos escolares encontramos ciertos dibujos de ciencia que nos sirvieron de referencia para conocer de cerca la célula, las partes y funciones del corazón humano, los sistemas del cuerpo humano, los planetas que conforman el sistema solar, por citar algunos ejemplos.

Para la ciencia y los investigadores es una necesidad primordial comunicar sus conceptos, procesos, hallazgos y resultados de investigación con la finalidad de hacerse visibles y posicionarse en el medio académico. Esta no es una tarea fácil si se pretende acceder a diferentes públicos. Para esto, la infografía y la visualización de datos conceden una forma de comunicación visual efectiva que brinda mayores posibilidades para transmitir el conocimiento a la comunidad académica, a las empresas y a la sociedad. 


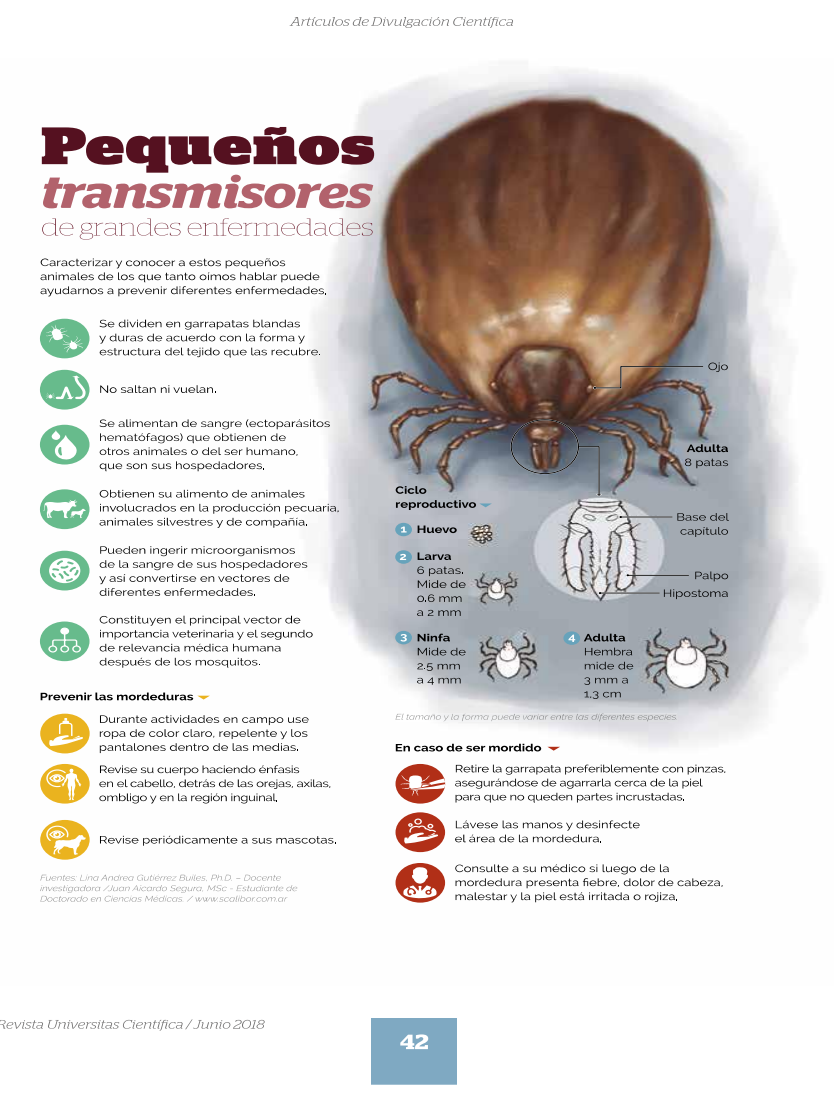

Imagen No. 4. Pequeños transmisores. Propuesta de Divulgación cientifica aprovechando elementos de la infografía en Revista Universitas Científica UPB.

Disponible en: https://revistas.upb.edu.co/index.php/universitas

Uno de los aspectos importantes y que se tiene como objetivo último en el proceso de investigación es la divulgación de los resultados, ya que este ejercicio de comunicación de la ciencia permite traducir el conocimiento científico a realidades sociales concretas y proporciona a través de la práctica mejorar aspectos de la vida diaria y productiva de las comunidades.

Los productos de investigación deben presentarse a las comunidades de manera precisa, clara y acsequible para que se establezca una buena comunicación y así lograr que sus resultados ayuden a mejorar la calidad de vida de todos. Es por esto que "la ciencia debe dirigirse siempre que se pueda a la obtención de beneficios sociales" (Valero, 2010: 65). 
Los relatos textuales tienen una fuerte presencia en los procesos de comunicación e información, y en especial en las publicaciones de divulgación científica, a pesar de que la imagen está presente dadas sus propiedades pedagógicas. En los dos últimos lustros, lo visual se volvió tendencia, ya que facilita la lectura rápida de los grandes volúmenes de información que circulan hoy en los medios de comunicación y en la red.

Es irrefutable la preponderancia que lo visual adquirió en los procesos de comunicación en los últimos años, además de tener la capacidad de replicar la realidad de un modo diferente como lo hacen las manifestaciones textuales u orales. Eso hace que éste juegue un papel importante en la transmisión de conocimiento. La capacidad que tienen las imágenes para "decir, comunicar, transmitir o representar cosas o hechos, permite que muchos libros y autores le lleven a la categoría de lenguaje” (Marín, 2013: 6).

En el proceso de comunicación, el emisor envía un mensaje codificado al receptor para que este lo analice y lo interprete de acuerdo a su punto de vista y a la experiencia adquirida a lo largo de su vida. Es así como la infografía, en calidad de emisor, transfiere la esencia de la información científica al receptor, que en nuestro caso se vuelve un intérprete, para acceder más fácil a un contenido que no conocía, su análisis y comprensión, y así lograr una expansión de la cognición y una efectiva transmisión del conocimiento.

Es ahí donde la apropiación social evidencia un importante papel, porque garantiza no solo que la comunidad adquiera conocimiento sobre un tema en particular, sino que lo haga parte de su cotidianidad y de su vida.

Por eso, es un reto que exige mucho tanto desde quien propone las estrategias como de quien obtiene el conocimiento y lo implementa en su día a día mientras se genera, integra y transforma la idea desde su propuesta inicial en un grupo social, "en un momento especifico y en una escala de relaciones simbólicas", asegura la investigadora mexicana y experta en el tema Carmen Gómez Mont (2015: 59) y agrega: 
Las tesis que amparan la categoria "apropiación social" nos lleva a ver varios niveles de uso o aplicación. Generalmente se habla de la apropiación social de una tecnología, pero con menor frecuencia de la apropiación social del conocimiento, un bien intangible.

El conocimiento existe únicamente si va de la mano de otros dos factores: la información y la comunicación que forman su naturaleza.

La apropiación posee varios niveles: a) el acceso a la información, al dato simple y escueto que circula por nuestras manos; b) la comprensión y correcta contextualización de cada dato que llega hasta nosotros; c) la reacción o construcción de una visión crítica ante el dato que se presenta y d) la posibilidad de compartirlo a través de redes sociales o redes digitales con el objeto de darle vida y renovarlo."

La apropiación social del conocimiento se convierte en un imperativo de estudio con la llegada del Big data, las TIC, los nuevos soportes virtuales de almacenamiento como la nube, obligan a pensarla mas desde como la reciben y usan las audiencias, los lectores, los usuarios.

\section{Infografía y visualización de datos}

Para la ciencia y los investigadores es importante comunicar de manera efectiva al público sus procesos y desarrollos de investigación. La infografía juega un papel importante en la divulgación y apropiación del conocimiento, ya que a estos públicos masivos les es más fácil acceder a la información de tipo visual por la manera como el cerebro procesa, organiza y almacena la información visual: "las imágenes visuales se almacenan en la memoria de una forma similar a como se almacena una instantánea en un álbum fotográfico" (Monteiro, 2013: 50).

Si bien la infografía ya existía desde comienzos del siglo XX y era aprovechada por algunos medios impresos, en la década de los noventa se convirtió en una apuesta necesaria para ampliar coberturas informativas de difícil acceso (como guerras o eventos catastróficos) o de gran cobertura (como los juegos olímpicos, un mundial de fútbol o una feria mundial) y la ciencia no fue ajena a ello. Es así como la infografía y con el tiempo la visualización de datos se constituye "como 
un nuevo modelo para concebir ideas y hacerlas propias, en respuesta a la condición bumana contemporánea y su capacidad de entendimiento, desarrollada en mayor medida a través de lo que observa que de lo que escucha" (Valero, 2001).
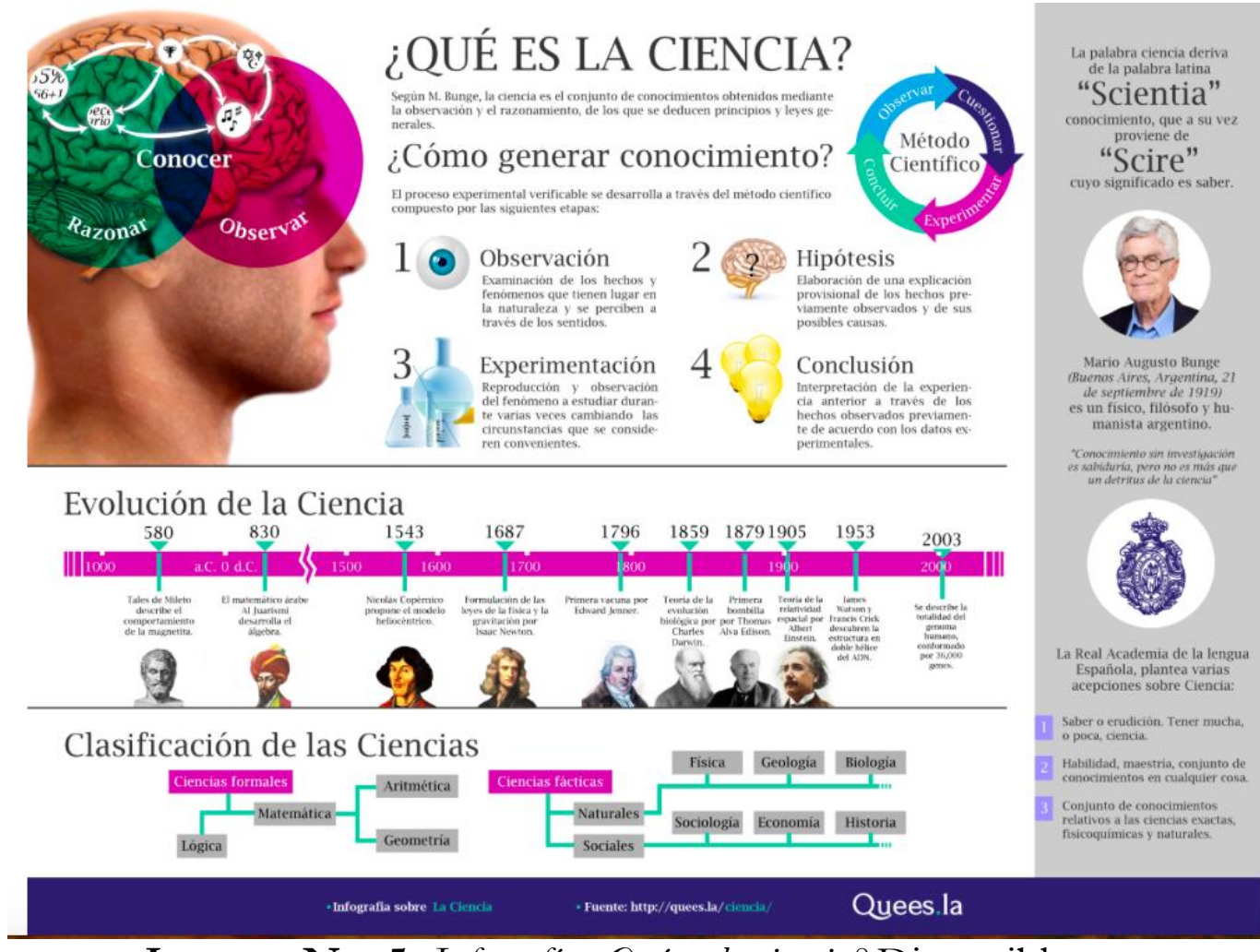

Imagen No. 5. Infografía ¿Qué es la ciencia? Disponible en:

https://alfredovela.files.wordpress.com/2013/06/infografia que es la ciencia .png

Cabe decir que la evolución tecnológica también aporta al desarrollo de estas capacidades humanas y a su vez éstas permitieron el desarrollo de la visualización de información. Desde sus antecedentes, la infografía ayuda a desarrollar un pensamiento estructurado y, por otra parte, a facilitar la comunicación de acontecimientos y fenómenos de alta complejidad.

En la actualidad, se habla con más frecuencia de infografía y visualización de datos. Un indicio de que es una tendencia en los últimos años, en especial desde el año 2012, cuando las búsquedas de la palabra "infografía" o "infographic" aumentaron en un 800 por ciento según Google. Alberto Cairo, en una entrevista ${ }^{18}$ concedida para la

18 Entrevista realizada el día 13 de noviembre de 2015, para el trabajo de grado de la Maestría en Diseño y Creación Interactiva de la Universidad de Caldas (Manizales, Colombia) 
construcción de la investigación que da origen a este texto, mencionó que el uso de estas imágenes informativas hoy es una tendencia creciente... gracias al hecho de que las imágenes atraen más la atención en medios sociales. De ahí que algunas empresas incluso la aprovechan como estrategia de promoción en marketing, y no solo como herramienta informativa como ha sido tradicional.

La infografía no solo tiene presencia en los medios de comunicación en los últimos años, aumentó con fuerza su uso en otros ámbitos, como los propios del conocimeinto científico. La ciencia la utiliza para presentar y difundir sus hallazgos, conceptos, teorías, metodologías y resultados, incluso ya se comienza hoy a explorar como una nueva forma de comunicación visual que permite acercar el conocimiento científico a la ciudadanía. Además, se explora y se le considera hoy como una posibilidad determinante en el mundo académico. En el ámbito comercial, se utiliza en los contenidos de las empresas para explicar los procesos, las etapas o las características de los productos, incluso los gobiernos la usan de forma efectiva para presentar informes de rendiciones de cuentas de las administraciones de turno a la sociedad.

Algunos incluso las aprovechan para sensibilizar sobre el manejo de un tema complejo que afecta a la sociedad porque se considera que una buena infografía o visualización de datos tiene la capacidad de alcanzar el objetivo informativa de una manera más clara... "la más sencilla de todas y la que hace posible su entendimiento sin la participación de ningún intrincado texto lleno de palabras impronunciables que nadie entiende, a veces ni siquiera los científicos" (Valero, 2010: 55-67).

Además, las infografías y visualizaciones de datos no solo adquieren una importancia significativa en términos estéticos, sino en la manera como éstas presentan la información, lo que permite en el ámbito de la divulgación científica, ser un facilitador de los temas de ciencia para el lector.

titulado Estudio y proyecto de visualización de información para la comunicación de la ciencia en los museos de ciencia. 
Estas representaciones suelen relacionarse con diferentes técnicas de expresión, de graficación de información y programas informáticos de procesamiento y edición de contenidos, sin embargo, autores y expertos en estos temas declaran hoy una ausencia de reflexiones en relación con las posibilidades que brinda este tipo de imágenes en la adquisición de conocimientos, incluso en la manera como las personas perciben de forma visual y procesan el contenido en el cerebro.

Es así como se considera preciso darle una mirada a las maneras como se definen los términos infografía y visualización de datos, ya que los diferentes puntos de vista nos ayudan a comprender su transformación y a dejar en evidencia sus posibilidades visuales, informativas, incluso formativas, de las que dispone el museo de ciencia para comunicar y favorecer la transmisión del conocimiento.

A partir del pensamiento de Sullivan (1987) podemos establecer un punto de origen y afirmar que el lenguaje se comenzó a gestar a partir del dibujo y luego, con el desarrollo de los pictogramas, los dibujos autosignificantes y las unidades fonéticas, se llegó al alfabeto. Dondis en la introducción de su libro La sintaxis de la imagen, ratifica esto al afirmar:"El lenguaje es, sencillamente, un recurso comunicacional con que cuenta el hombre de modo natural y ba evolucionado desde su forma primigenia y pura hasta la alfabetidad, hasta la lectura y la escritura." (2017:3).

Por su parte, Valero (2001) sostiene que el origen de la infografía moderna se gesta en los años sesenta en los laboratorios científicos y militares en los que usaban imágenes elaboradas por computador como una herramienta en los programas de simulación aeronáutica y para otros usos en la milicia.

Cabe resaltar que este tipo de imagen, en el ámbito científico, ha permitido visualizar el mundo celular, las partes del cuerpo humano, los planetas y el universo, por mencionar algunos casos, tanto a partir de observaciones de laboratorio o en campo, como por la graficación computacional de imágenes virtuales. 


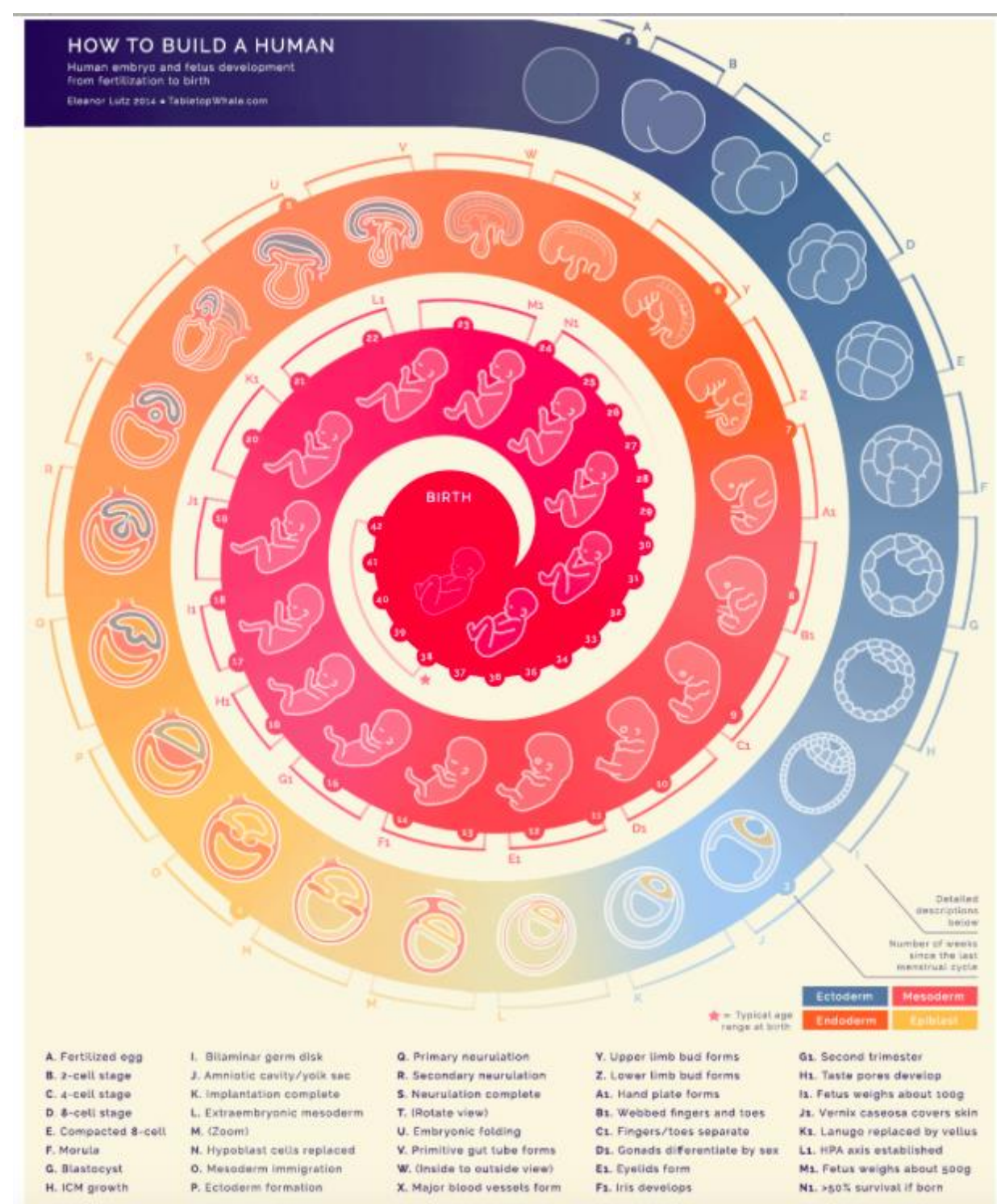

Imagen No. 6. Infografía ¿How to build buman? En: Cultura Científica. Disponible en: https://culturacientifica.com/app/uploads/2015/10/12-1614.gif

Ahora bien, Holmqvist en su artículo Estudios de seguimiento de la mirada en condiciones experimentales. La lectura de infografías, define la infografía como un género multimodal utilizado en periódicos, revistas, libros y artículos científicos para explicar acontecimientos complejos, estructuras, fases de un proceso, desarrollos en el tiempo (cronologías), relaciones espaciales, entre otros, así como las causas y efectos de una acción, mediante representaciones visuales que ilustran y facilitan al lector su conceptualización y comprensión, y agrega que "a menudo se emplea para introducir la ubicación y función de los órganos internos, las causas y efectos de las lesiones, tratamiento médico, etc. (2005: 55). 
En cuando a visualización de datos, se puede decir que son imágenes informativas que propician la interacción con los datos, ya sea que estén insertos en la pieza o almacenados en repositorios o bases de datos, incluso en tiempo real, y que se vuelven visibles a medida que el usuario los manipula. Por su parte, Cairo (2012) utiliza la palabra "visualización", como un término genérico, para referirse a la representación gráfica de información que tiene como propósito facilitar la comunicación, el análisis, la exploración y la comprensión de los datos.

Además, estas imágenes son útiles porque ayudan a revelar verdades o realidades que se encuentran en el interior de los datos y que salen al relieve al ser visualizadas. Cairo (2016) plantea que la visualización se divide en cuatro sub-áreas: gráficos estadísticos, mapas estadísticos, visualizaciones de datos, infografías y aplicaciones de noticias.

Los gráficos estadísticos son representaciones de datos numéricos en forma de barras, líneas, tortas, etcétera. Los mapas estadísticos usan datos numéricos graficados sobre el territorio para mostrar concentraciones y distribuciones geográficas. Las visualizaciones de datos muestran de manera gráfica datos cuantitativos para facilitar su exploración y análisis. Al contrario de las infografías, estas gráficas suelen manejar grandes cantidades de información y son elaboradas con ayuda de programas informáticos y un computador (Cairo, 2016; Iliinsky, 2012).

Las infografías son construcciones narrativas que cuentan una historia de manera estructurada combinando cuerpos de texto y diferentes herramientas y técnicas de graficación (ilustraciones, diagramas, mapas, gráficos estadísticos). En comparación con la visualización de datos, estas representaciones suelen ser más análogas (dibujo técnico y artístico) y manejan menos cantidad de información (Iliinsky, 2012). Las aplicaciones de noticias son herramientas interactivas desarrolladas en medios de comunicación para facilitar la manipulación de los datos de acuerdo a las intenciones o necesidades del usuario.

El contenido de estas visualizaciones debe estar orientada por el argumento principal o el significado esencial de un determinado tema, 
de tal manera que satisfaga en términos informativos, incluso impresione desde lo visual a su intérprete favoreciendo la comprensión y retención del contenido (Valero, 2010; Marín, 2013).

\section{Museos de ciencia}

Los museos, en especial los de ciencia, no son ajenos a ello y encuentran en este tipo de propuestas de presentaciones periodísticas y audiovisuales las bondades de la infografía y la visualización de datos, para de esta manera acercar los fenómenos científicos al ciudadano interesado en conocer sus desarrollos y en ampliar su conocimiento.

A partir de estas estrategias de comunicación, los museos de ciencia hoy diseñan y producen sus montajes museográficos, no solo en la búsqueda de informar, sino de formar a sus públicos, a través de exposiciones más visuales que ilustran y explican contenidos complejos con ayuda de gráficos y dispositivos que propician la interacción y la apropiación social del conocimiento científico.

Recordemos que el concepto museo tiene su origen en el latín "museum" y en el griego "mouseion" que hace referencia a lugar de contemplación o casa de las musas, lugar que en Roma era el lugar de discusión filosófica que Fernández comenta: ...descrito era, en realidad, un complejo del siglo III a.C. que incluía además de la famosa Biblioteca, un observatorio astronómico, un jardín botánico, una colección zoológica, las salas de trabajo y estudio y el anfiteatro... $(2013,28)$.

En el 2007 el International Council Of Museums o Consejo Internacional de los Museos-ICOM ${ }^{19}$ lo definió como: "una institución permanente, sin fines de lucro, al servicio de la sociedad y de su desarrollo, abierta alpúblico que adquiere, conserva, estudia, expone y transmite el patrimonio material $e$ inmaterial de la bumanidad y de su medio ambiente con fines de educación $y$ deleite" ${ }^{20}$.

\footnotetext{
${ }^{19}$ Es una organización de museos y profesionales de museos a nivel mundial que se dedica a promocionar y proteger el patrimonio cultural y natural, presente o futuro, material o inmaterial. Fue fundada en 1946.

${ }^{20}$ Recuperado el 4 de abril de 2017, de: http://icom.museum/la-vision/definicion-del-museo/L/1/
} 


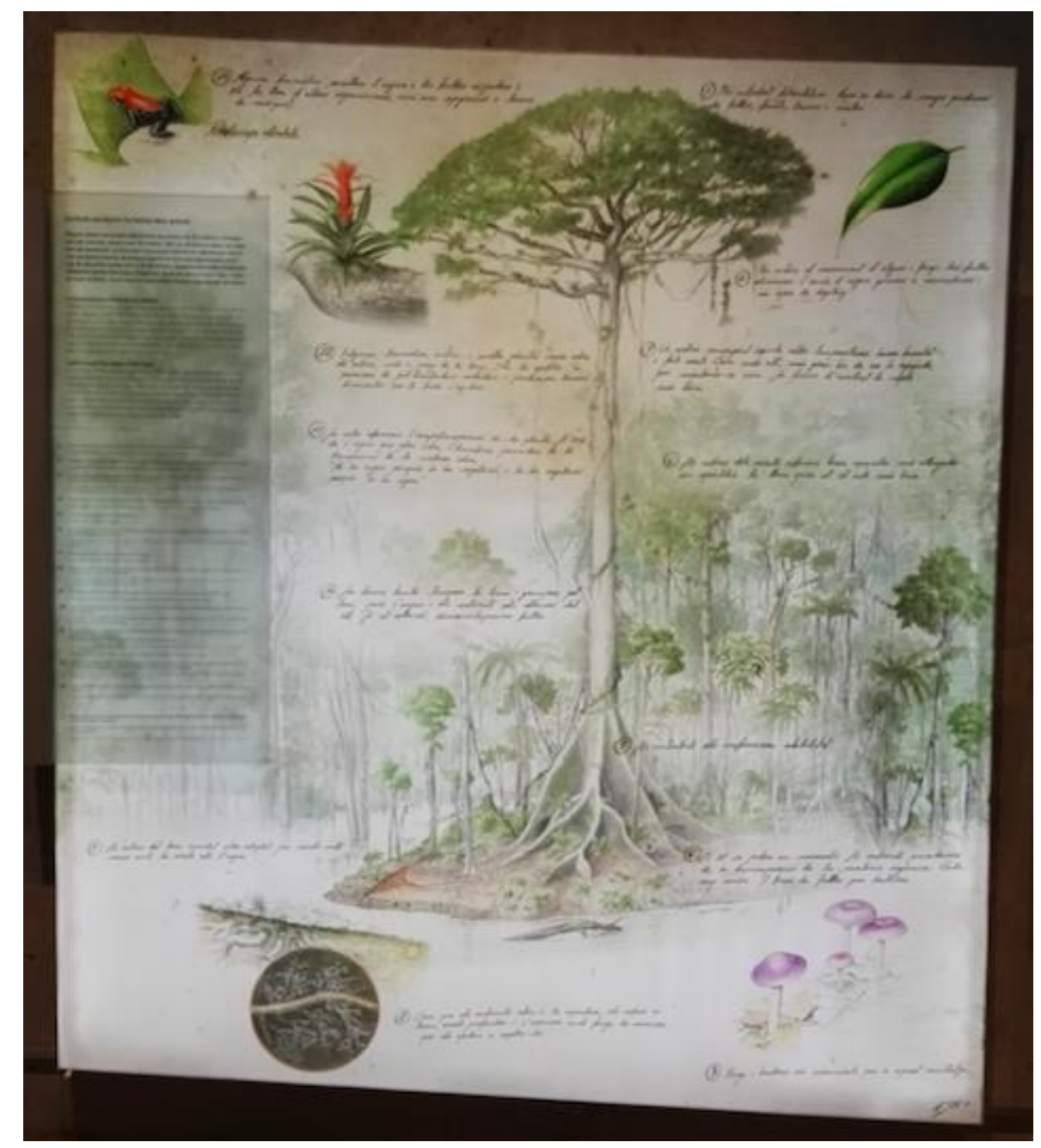

Imagen No. 7. Bosque Inundado. En CosmoCaixa, Barcelona. Archivo personal

Pero, en 2013 el ICOM amplió la definición:

...designa a todo establecimiento permanente, administrado en beneficio del interés general para conservar estudiar, hacer valer por medios diversos $y$, sobre todo, exponer por deleite y educación del públicos un conjunto de elementos de valor cultural: colecciones de objetos artísticos, históricos, cientificos y técnicos, jardines botánicos y zoológicos y acuarios. Las bibliotecas públicas y los centros de archivos que atienden salas de exposición de manera permanente serán asimilados a los museos. (Fernández, 2013: 28)

El museo de ciencia, como espacio educativo no convencional, ha estado en constante búsqueda de estrategias de comunicación efectivas que le permita cerrar la brecha que de manera general y tradicional se ha trazado entre las ciencias y la ciudadanía. Es así como sus exhibiciones hoy hacen uso de manera preponderante de imágenes que 
ilustran y explican en profundidad conceptos científicos que permiten dar contexto y entender cómo funcionan los fenómenos y teorías científicas. Estas infografías y visualizaciones de datos expuestas posibilitan la interacción, en su mayoría con ayuda de dispositivos, entre el conocimiento científico y el intérprete, y favorecen la apropiación de los contenidos a través de lo visual.

A pesar de que se habla de la importancia de la infografía y la visualización de datos como recursos que posibilitan la comprensión de información compleja y potencian la comunicación y la apropiación de la ciencia en los museos, los estudios sobre este tema aún son escasos y en algunos centros no han dado el valor a esta forma de comunicación y no la aprovecha de la forma más adecuada.

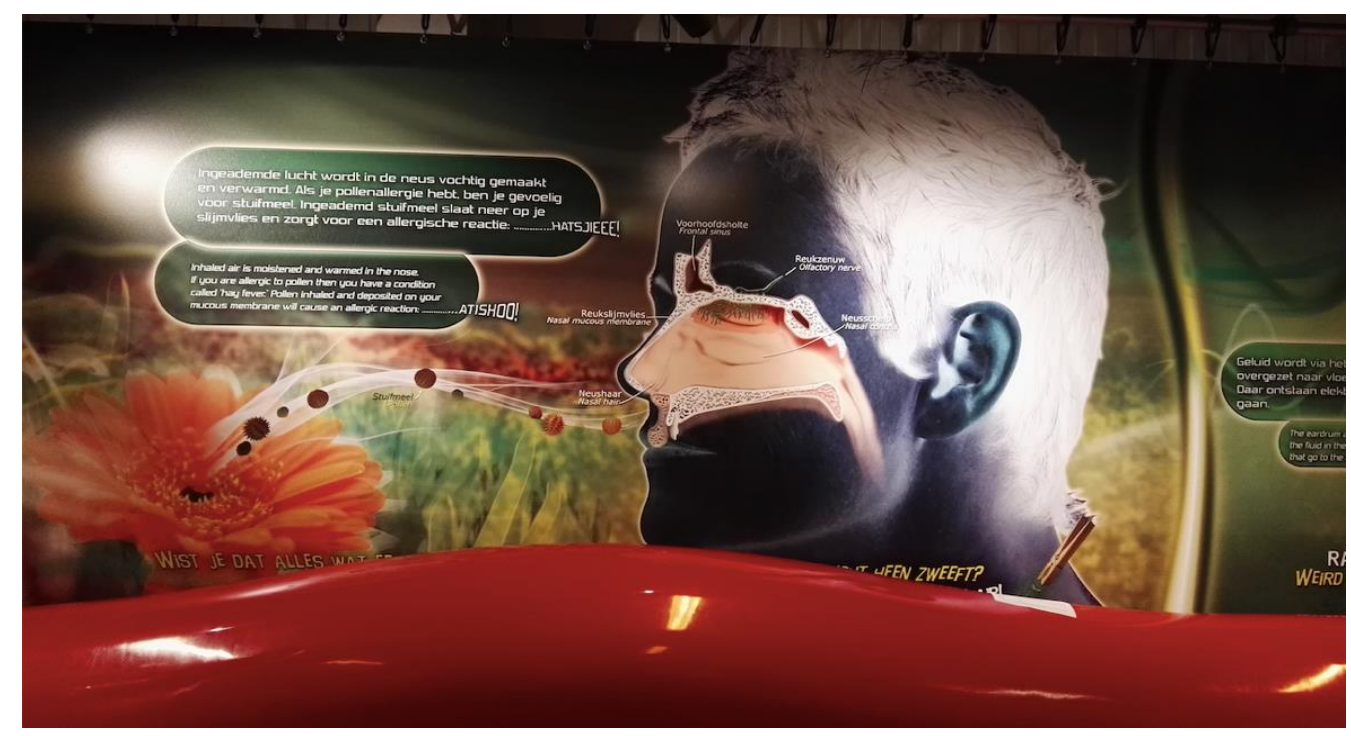

Imagen No. 8. Corpus. Museo Leiden Holanda. Archivo personal.

En relación con la Visualización de información para la comunicación de la ciencia en los museos hay un antecedente conocido: el proyecto ISOTYPE ${ }^{21}$, desarrollado a finales de la década de 1920 por Otto Neurath desde la dirección del Museo de la Sociedad y la Economía de Viena, junto a su esposa Marie Neurath, el asesor Willard Brinton y el diseñador gráfico Gerd Arntz. Su propósito fue elaborar un sistema de comunicación mediante imágenes -lenguaje visual de signos codificados-, para proporcionar información más exacta a cualquier ciudadano, sin importar su nivel educativo, y facilitar su comprensión.

${ }^{21}$ Internacional System Of TYpographic Picture Education 
Haroz, Kosara y Franconeri (2015), en su artículo ISOTYPE visualization - working memory, performance, and engagement with pictographs, resaltan que el objetivo de ISOTYPE fue elaborar "un sistema universalmente comprensible para comunicar cantidades de información comercial, social o económica (por ejemplo, la producción de automóviles o el número de hijos nacidos al año). Los símbolos, cada uno representando una cantidad fija, se apilaron para proporcionar una representación intuitiva de una cantidad total" (2015: $10)$.

Los museos de ciencia poseen unas características que hacen que la infografía y la visualización de datos sean estrategias muy útiles para alcanzar sus objetivos informativos y formativos. La complejidad de los temas que cubre la ciencia (ciencias de la tierra, ciencias del espacio, biología, antropología, etcétera) y la común y tradicional desconexión del trabajo científico con la sociedad, hace que estos contenidos demanden explicaciones que sean comprendidas por el visitante.

Para lograr una correcta comunicación de la información científica es imprescindible "interpretar, traducir al lenguaje cotidiano, elaborar y explicar de una forma divulgativa" (Belenguer, 1999: 30).

La mayoría de artículos científicos publicados en revistas, periódicos y suplementos no están relacionados con la actualidad noticiosa del momento, lo que permite encontrar trabajos periodísticos de calidad con una función más formativa que informativa. Esta idea también permea las dinámicas del museo, ya que el diseño y desarrollo de una exhibición museográfica es un proceso largo y complejo que requiere un enfoque no solo informativo, sino pedagógico, incluso lúdico, lo cual permite profundizar en asuntos de alta complejidad científica. Otro asunto que cabe resaltar es la difícil asimilación del conocimiento científico por parte de los ciudadanos y a su vez la falta de interés o conocimiento de los medios y museos por comunicarla.

En la comunicación y enseñanza de las ciencias, fuera del ambiente periodístico, siempre se han empleado formas visuales como esquemas, dibujos, gráficos, entre otros. Belenguer manifiesta: sería inconcebible asistir a una clase de anatomía para escolares sin tener delante un 
dibujo del cuerpo bumano que enseñe a los niños dónde está cada bueso (1999: 30). En este sentido, la comunicación y el periodismo científico, en nuestro caso los museos de ciencia, han encontrado problemas para explicar una idea de manera clara a través de la escritura lineal, ya que este lenguaje se hace insuficiente para facilitar la comprensión de estos temas. Esos son los errores mas comunes en museos de todo tipo.

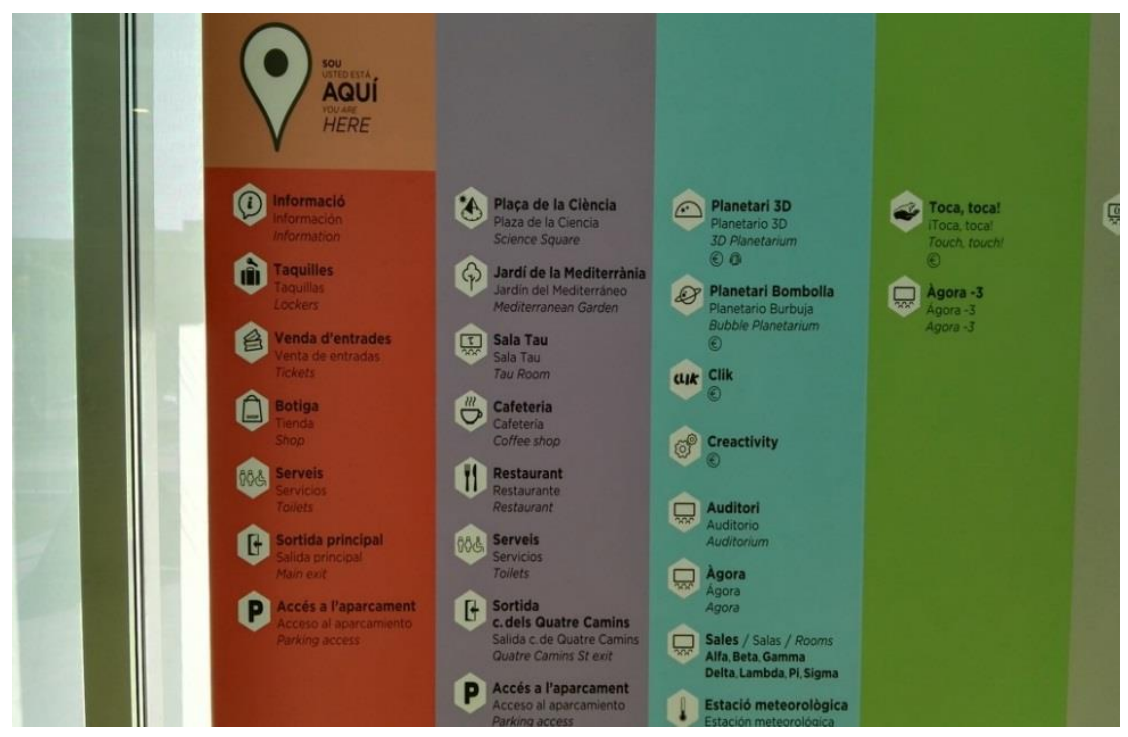

Imagen No. 9. Señalética. En CosmoCaixa. Archivo personal.

Es así como la infografía y la visualización de datos, por sus capacidades para documentar y facilitar la asociación, el análisis y la comprensión de la información científica, se convierte en una forma de comunicación visual efectiva para los museos de ciencia. Estas visualizaciones de información "sirven para describir, visualizar y explicar, y además de una forma rápida y atractiva para el lector" (Belenguer, 1999: 30).

$Y$ es que los museos fueron creados para guardar, clasificar, coleccionar, exhibir y cuidar los objetos de valor histórico y patrimonial de un colectivo social, con la idea de facilitar la relación del artista con la sociedad, porque "el artista tiene una necesidad de buscar la interacción con el público; pero es también necesidad de la sociedad entera convertirse en público del arte y apropiarse de sus formas" (Soto, 2005).

Esta reflexión nos lleva a entender la importancia de la expografía, el estudio de los conocimientos prácticos y técnicos que facilitan la relación autor-obra-visitante y que incluye: "desde la iluminación, conservación,... hasta los más sutiles del diálogo del objeto con la arquitectura, la 
orientación y la relación entre las piezas de una exposición, la percepción del visitante y el estudio de los puntos de vista." (Rico, 2006: 17).

Y es imporante porque la actividad expográfica es la única forma que se considera para presentar a la comunidad las riquezas que cierran los museos, los parques de ciencia y los sitios de conocimiento relacionados con la comunidad y por eso es importante aprovechar herramientas como la infografía y la visualización de datos en función de una apropiación social de conocimiento e información de calidad.

La mala o pobre información sobre expografía puede convertirse en un virus que carcome lo poco que los esfuerzos institucionales e independientes han venido logrando y puede incluso venir a infectar los nuevos museos de arte cuando finalmente logremos tenerlos. (Soto, 2015).

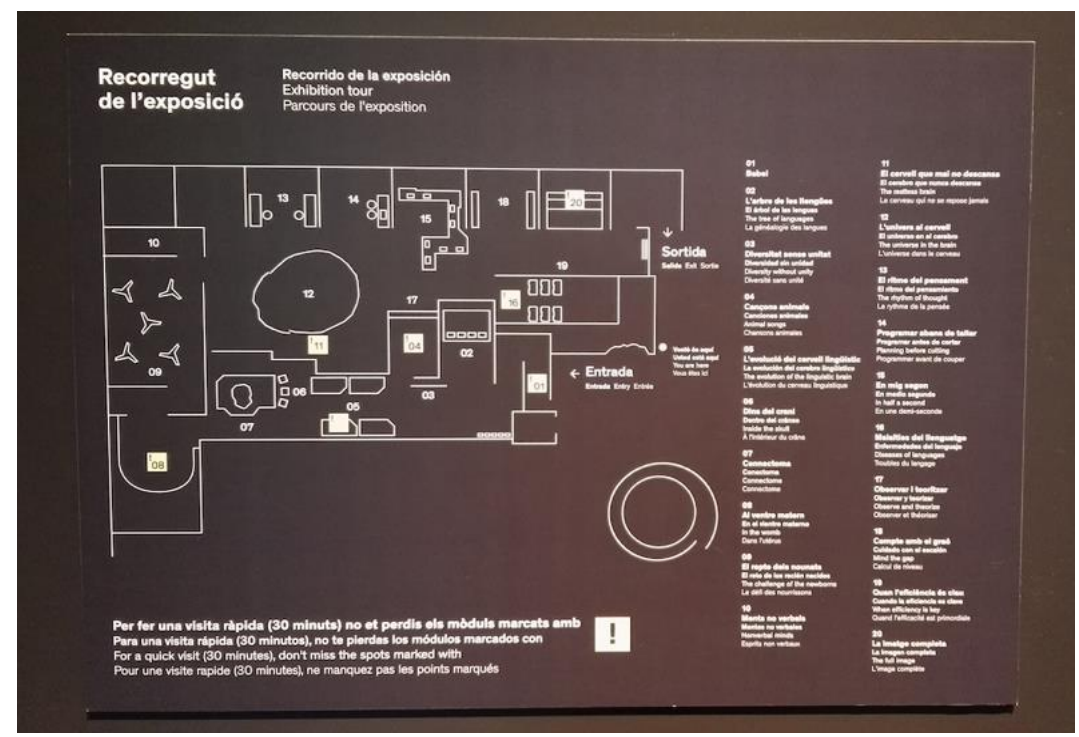

Imagen No. 10. Plano del recorrido en la exposición Taking Brains. En CosmoCaixa. Archivo personal.

Los museos deben también avanzar en estudios sobre el público, las formas de comunicación con ellos, si bien muchos museos cuentan con ellos, es importante también revisar "su comportamiento en las salas y como mejorar el contacto entre la ciencia y el público a través de las exposiciones" (Bonilla, 2015: sp.), además de realizar propuestas estratégicas claras que garanticen la apropiacion social del conocimiento. 
La infografía y la visualización son una excelente apuesta en el proceso, porque los medios informativos visuales y el aprovechamiento de los datos de las piezas pueden contribuir a una mejor comprensión: unos datos que pueden ayudar a leer y comprender mejor la pieza, reconstruirla, mostrar su funcionamiento, interpretarla, contextualizarla y ampliar los detalles particulares que no se observan a simple vista.

\section{Conclusiones}

El ser humano siempre busca diferentes maneras de comprenderse a sí mismo y al mundo que lo rodea. El sistema visual -el ojo- funciona como una cámara instantánea que captura imágenes del entorno que son procesadas, organizadas y almacenadas en el cerebro para facilitar su memorización, razonamiento y comprensión, incluso para ayudar a desarrollar nuevas habilidades. Todo tipo de representación está sujeta a los propósitos, necesidades o especificaciones del contexto que la produce, por tanto, debe asumir cambios en su representación gráfica.

La infografía y la visualización de datos como recursos que aportan a la transmisión y apropiación del conocimiento, se convierten en una estrategia y forma de comunicación visual efectiva para el museo de ciencias, ya que favorecen la asociación, el análisis y la comprensión de los saberes de la ciencia, la tecnología y la innovación por los visitantes.

Al identificar las maneras como perciben y adquieren conocimiento las personas que visitan el museo de ciencias, permite tener herramientas útiles para diseñar y desarrollar infografías y visualizaciones de datos de variable complejidad informativa para las exhibiciones del museo de ciencias, incluso para sus productos de divulgación. Además, les permite a estos espacios de educación no-convencional ofrecer información visual científica de manera sintética, con palabras sencillas y en contexto, para ser interpretada y de fácil de recordación en clave de lectura.

\section{Referencias bibliográficas}

Belenguer, J. M. (1999). "La infografía aplicada al periodismo científico". Chasqui, 66 (junio), pp. 27-30. Recuperado septiembre 15 
de 2018 en:

http://repositorio.flacsoandes.edu.ec/xmlui/handle/10469/11343

Bonilla, A. (2015). Apropiación social del conocimiento, el objetivo de los museos. Agencia informática, Conacyt (México). Recuperado septiembre 15 de 2018 en:

http://www.conacytprensa.mx/index.php/sociedad/museos/3087apropiacion-social-del-conocimiento-el-objetivo-de-los-museos-deciencia

Cairo, A. (2012): The functional art. An introduction to information graphics and visualization. Harrow (Reino Unido): New Riders

_(2016): "Infografía y visualización de datos con D3". Vídeo. Knight Center for Journalism in the Americas. Recuperado el 15 de septiembre de 2018, en: https://www.youtube.com/watch?v=AoN6XwLUrLk

CM Editores (s/f). Codex Madrid I y II: Leonardo Da Vinci. Madrid. Recuperada el 15 de septiembre de 2018, en: http://www.codicesmedievales.com/colecciones-homet/coleccioncodices-ilustrest/codex-madrid-leonardo-da-vinci-facsimilt.html

Dondis, A. (2017) La sintaxis de la imagen. Madrid: Gustavo Gilli. Introducción recuperada en Internet el 15 de septiembre en: https://jenydreher.files.wordpress.com/2013/06/dondis-la-sintaxisde-la-imagen.pdf

Fernández, L. F. (2013) Museología y museografía. Barcelona: Ediciones del Serbal

Gómez, C. (2015) "La apropiación social del conocimiento", Revista Universitas cientifica. Medellín: Universidad Pontificia Bolivariana, pp. 58-61

Haroz, R. K. \& Franconeri, S. (2015): “ISOTYPE visualization working memory, performance, and engagement with pictographs", In Conference on Human Factors in Computing Systems - Proceedings (Seúl), pp. 1191-1200. DOI:10.1145/2702123.2702275 
Holmqvist, K. (2005): "Estudios de seguimiento de la mirada en condiciones experimentales. La lectura de infografías". Capítulo español. In Society for News Design (ed.). 13 premios internacionales de infografía Malofiej. Pamplona (España), pp. 54-61

ICOM (2010). Conceptos claves de museología. ICOM, 2010. Recuperado septiembre 15 de 2018 en: http://icom.museum/fileadmin/user upload/pdf/Key Concepts of Museology/Museologie $\% 20$ Espagnol BD.pdf

Iliinsky, N. (2012): "Designing data visualizations". LinkedIn Tech Talk. Recuperado septiembre 15 de 2018 en: https://www.youtube.com/watch?v=R-oiKt7bUU8

Lima, M. (2015): “Una historia visual del conocimiento humano”. TED. Recuperado septiembre 15 de 2018 en:

https://www.ted.com/talks/manuel lima a visual history of huma $\underline{n}$ knowledge?language $=$ es

Marín-Ochoa, B. E. (2010). La infografía digital, una nueva forma de comunicación. Tesis Doctoral en Comunicación y Periodismo. Universidad Autónoma de Barcelona. Recuperado septiembre 15 de 2018 de:

https://www.tdx.cat/bitstream/handle/10803/48653/bemo1de1.pdf

Marín-Ochoa, B. E (2013): “La infografía y su aporte a la apropiación social del conocimiento". Apropiación social del conocimiento. El papel de la comunicación. Medellín: Universidad de Antioquia, pp. 162-181;

Recuperado septiembre 15 de 2018 de:

https://www.academia.edu/18460893/Apropiación social del cono cimiento. El papel de la comunicación

Monteiro, P. y Lemos, J. (2013): “¿Infografía? Sí, claro, es la forma como trabaja el cerebro". Capítulo español. In Society for News Design (ed.). 20 premios internacionales de infografía Malofiej. Pamplona (España), pp. 4459

Navoni, M. (2012). Leonardo Da Vinci y los secretos del Códice Atlántico. Folio 844r. Barcelona: Blume 
Rico, J. C. (2006). Museos, Arquitectura, Arte. Madrid: Silex

Rodríguez, A. (2013): "Infografía y visualización de información como recurso para divulgar y comunicar la ciencia”. Congreso RedPop 2013. La recreación para la re-creación del conocimiento; Recuperado septiembre 15 de 2018 en: http://www.redpop.org/wpcontent/uploads/large/LIBRO SOMEDICYT.pdf

Romero, R. (2007). “Andreas Vesalius (1514-1564): Fundador de la Anatomía Humana Moderna”. International Journal of Morphology, 25(4), pp. 847-850. Recuperado septiembre 15 de 2018 en: en: https://dx.doi.org/10.4067/S0717-95022007000400026

Soto, M. (2005) "El Papel de la Expografía en el Discurso Museológico". Cuadernos de estudios fornterizos. Recuperado septiembre 15 de 2018 en: http://www.fronterismo.org/transfronterizos/wpcontent/uploads/2015/08/El-papel-de-la-expografia-corregidoFormatted-PDF-ESP.pdf

Sullivan, P. (1987). Newspaper Graphics. Darsmtadt (Alemania): IFRA

Valero, J. L. (2001) La infografía: técnicas, análisis y usos periodísticos. Valencia (España): Universidad de Valencia; Castellón de la Plana (España): Publicaciones de la Universidad Jaume I; Barcelona: Universidad Pompeu Fabra; Bellaterra (España): Universidad Autómoma de Barcelona

Valero, J. L. (2010): "La infografía al servicio de la comunicación de la ciencia". Revista Universitas Cientifica, 13. Medellín: Universidad Pontificia Bolivariana, pp. 64-67. Recuperado septiembre 15 de 2018 en:

https://revistas.upb.edu.co/index.php/universitas/article/view/1276 


\title{
Infografía periodística o visualización de datos en clave de semiología
}

\author{
Beatriz Elena Marín-Ochoa (ำ $)$. \\ Facultad de Comunicación Social - Periodismo, \\ GI Comunicación Urbana, UPB, Colombia. \\ beatrize.marin@upb.edu.co \\ Federico Medina Cano (ㄷ) \\ Facultad de Comunicación Social - Periodismo, \\ GI Comunicación Urbana, UPB, Colombia. \\ federico.medina@upb.edu.co
}

Resumen. La infografía periodística, aparece desde el siglo XIX en los medios impresos y posteriormente en los digitales como un apoyo a la información. Pero, con la llegada de la sociedad del siglo XXI, los medios de comunicación redimensionaron el papel de propuestas como la infografía en una tendencia denominada visualizaciones de datos. Por tradición los medios han clasificado la información en secciones para organizar y facilitar la lectura a sus usuarios, y generalmente estas clasificaciones responden al perfil que cada medio tiene de sus potenciales lectores y del tipo de información que consumen, al punto que hay medios especializados en un solo tema, lo que suele también estar en relación con la situación social y la cultura de cada país.

Sin embargo, es posible reconocer algunos temas de esa clasificación en los que la infografía adquiere un protagonismo especial que responde a diversas posibilidades que van desde la facilidad o dificultad para acceder a la información, pasando por su tratamiento hasta el perfil detectado por el medio entre sus lectores. 
Aunque en la última década con el auge del Big Data y las redes de comunicación incursionaron de forma amplia las denominadas Visualizaciones de datos que dan una fuerza especial a todos los temas cuyo mayor potencial lo configura la información almacenada en bases de datos -como por ejemplo la referente a economía, política o incluso tecnología- es tradicional en los medios que tres temas sean de particular interés infográfico entre los lectores: la ciencia, el deporte y las guerras.

Esa continuidad en el desarrollo de estos tres últimos, es una de las motivaciones que nos llevan a analizarlas y clasificarlas a la luz del periodismo y la semiología. La semiología es, según Saussure, la ciencia que estudia la vida de los signos en el seno de la vida social y es el periodismo quién presenta esos contenidos en la vida social.

Palabras clave: Visualización de datos, infografía, semiología, ciencia y tecnología, deportes, guerra.

\section{De pixeles a big data}

— N LA ACTUALIDAD hay más información de la que se pueda globalización han provocado un verdadero estallido de datos, imágenes, textos y sonidos, un crecimiento exponencial de la información. En las últimas décadas con el desarrollo del big data, de las bases de datos que se ubican en distintos servidores, el aumento de la información ha sido sorprendente y se hace necesaria una real gestión del conocimiento. El diagnostico no es positivo y las dimensiones del fenómeno son enormes, así lo expresa Trejos (2002, sp.):

La abundancia de información que hormiguea por la red de redes se ha convertido en prácticamente inaccesible por sus dimensiones colosales. Los más tecnificados buscadores de contenidos, como Goggle y Yahoo, apenas alcanzan a rastrear una quinta parte de todo el acervo - en donde bay de todo- en la $W W W$. La Internet se ha convertido en una sucesión de océanos en donde solo es posible no extraviarse si se tienen experiencia y brújulas adecuadas. 
Es así como por los medios masivos, internet y las redes sociales circulan un número muy amplio y renovado de noticias de actualidad, de apreciaciones, miradas e interpretaciones sobre la realidad, de información documental e institucional, de testimonios acompañados de juicios de valor, y de muchos datos... pero esto no supone, como efecto inmediato que los sujetos están más y mejor informados. Al contrario, la abundancia de información provoca complejidad y hace difícil su interpretación Así lo expresa Ramonet (2001: 218):

La Información, durante mucho tiempo dificil y costosa, se ha tornado prolifica y pululante. Junto con el agua y el aire, se trata indudablemente del elemento que más abunda en el planeta. Cada vez menos cara, en la medida que aumenta su caudal, pero como sucede con el aire y el agua, cada vez más contaminada.

Y agrega: "Estamos en una era donde aumenta la confusión. La forma moderna de censura consiste en sobreañadir y acumular información" (2002: 30).

Realmente a los públicos se les hace muy arduo procesar este material, resaltar lo esencial y profundizar en los contenidos. Ante esta evidencia el reto para los comunicadores y los académicos es cómo procesar este mar de información, cómo decantarla para que sea útil (para que cumpla una función vital para los sujetos), cómo hacer posible que los lectores puedan acceder al conocimiento desde la comprensión, cómo transmitir información de forma clara y con eficacia, cómo comunicarla y facilitar con ello los procesos cognoscitivos. Como una respuesta a estas preguntas nace la visualización de datos. Esta metodología permite presentar visualmente el conocimiento, diseñar contenidos y desplegarlos con efectos estéticos para facilitar su comprensión y apropiación, poner en orden la diversidad de datos, los análisis de la realidad social y natural para que los intérpretes los entiendan, transmitir la información de manera clara y eficaz, "cercana y didáctica" (Valero, 2014: 1). Es una forma de abordar el saber y divulgarlo, con exactitud y de forma detallada, con el uso de medios gráficos, de imágenes figurativas o no, originales y novedosas; de poner a disposición de todos los públicos datos y contenidos de carácter científico, educativo o informativo por medio de una comunicación 
visual, multimediática e interactiva. La infografía periodística es una de las metodologías utilizadas en la visualización de datos.

La infografía periodística es una tendencia en el periodismo, una manera diferente de abordar la información que se aleja de los formatos periodísticos tradicionales. En la actualidad cualquier medio impreso (revista o periódico), página web o canal de televisión acompaña la información con infografías. Esta tendencia es el resultado de un giro epistemológico, de un énfasis en la labor pedagógica de los medios. Su objetivo es comunicar la información de manera visual y organizada para facilitar la comprensión de lo ocurrido. Pero no es solo el resultado de un cambio formal, la infografía supone la implementación de una nueva manera de abordar los contenidos informativos, una inversión del valor del texto y de la imagen en la presentación de la noticia, una revaloración de las técnicas argumentativas, las formas de representación de los contenidos y la organización del discurso. Cuando una idea o un contenido es difícil de explicar y el texto no da cuenta de toda su dimensión, "resulta de suma utilidad hacerlo mediante una imagen convenientemente apoyada con breves explicaciones textuales" (Valero, 1999-2000: 127). En la infografía el texto adquiere otro papel y la imagen empieza a tener un valor protagónico, a ser la portadora principal de la información y a no tener que traducirse verbalmente para ser entendida.

La infografía es un formato periodístico-pedagógico que busca poner al alcance del gran público los hechos que por su complejidad y particularidad requieren de la mirada de un experto o de un especialista. Es una metodología que re-presenta de una manera organizada y didáctica la información que es compleja y maximiza la comprensión de lo que se está informando. En ella se sustituye el texto informativo convencional por un conjunto de textos breves y directos, acompañados de elementos icónicos reconocibles fácilmente (de fotografías e ilustraciones), de elementos gráficos explicativos (de representaciones analógicas, dibujos figurativos y abstractos, de pictogramas, mapas, gráficos o esquemas), de piezas tipográficas variadas (de mensajes escritos en los que se emplean diferentes tipos de letras, colores y formas) y una serie de propuestas de diseño y diagramación (la presentación de los datos está vinculada al diseño) 
(Valero, 2001: 21), que buscan promover el entendimiento, hacer comprensibles los acontecimientos de la actualidad, los fenómenos (con su red de causas y efectos) y los procesos (que tienen un desarrollo en el tiempo), los datos y las cifras que a veces parecen inconexas o carentes de forma.

\section{La imagen y la condición humana}

La imagen no es característica de la época actual, ni es un "lenguaje" que viene exclusivamente con las nuevas tecnologías. "La información visual es el registro más antiguo de la historia" (Dondis, 1992: 15). La imagen siempre ha estado presente como instrumento de comunicación y ha acompañado al hombre a lo largo de los tiempos. En todas las civilizaciones, desde los orígenes de la condición humana, está presente en las formas más diversas (dibujos, códices, estampas, miniaturas, frescos, murales, vitrales, grabados, caricaturas, carteles, daguerrotipos, fotografías, cómics, fotografías, videojuegos hasta las propuestas multimediales) y ha cumplido las funciones más variadas (es símbolo, testimonio de los hechos históricos, apoyo de la memoria, centro de la expresión artística, complemento de los ceremoniales religiosos o mágicos, ilustración de las ideas, etc.).

Los hombres desde los comienzos de la humanidad han confeccionado imágenes para comunicarse, para registrar sus percepciones, para dejar testimonio de sus acciones, para marcar su territorio, para dominar la naturaleza y los seres con los que tenía relación, para instaurar su lugar en el entorno. Los precursores más antiguos de estas imágenes fueron las pinturas rupestres, los pictogramas y las figuras que dejaron algunas culturas prehistóricas (del paleolítico) en cuevas y en materiales rocosos o pétreos (como se puede apreciar en las cuevas de Lascaux, Chauvet, Rouffignac, Niaux o Altamira en Europa o en algunos parajes rocosos en la serranía La Lindosa en San José del Guaviare, Boyacá o el parque nacional Sierra del Chiribiquete en Colombia). Estas imágenes son la primera presencia humana en la tierra, remiten al espectador a un mundo vagamente estructurado, con una organización social incipiente, sumergido todavía "en la brumosa indiferencia de la materia" (Vitta, 2003: 98) y dependiente de los ciclos de la naturaleza. 


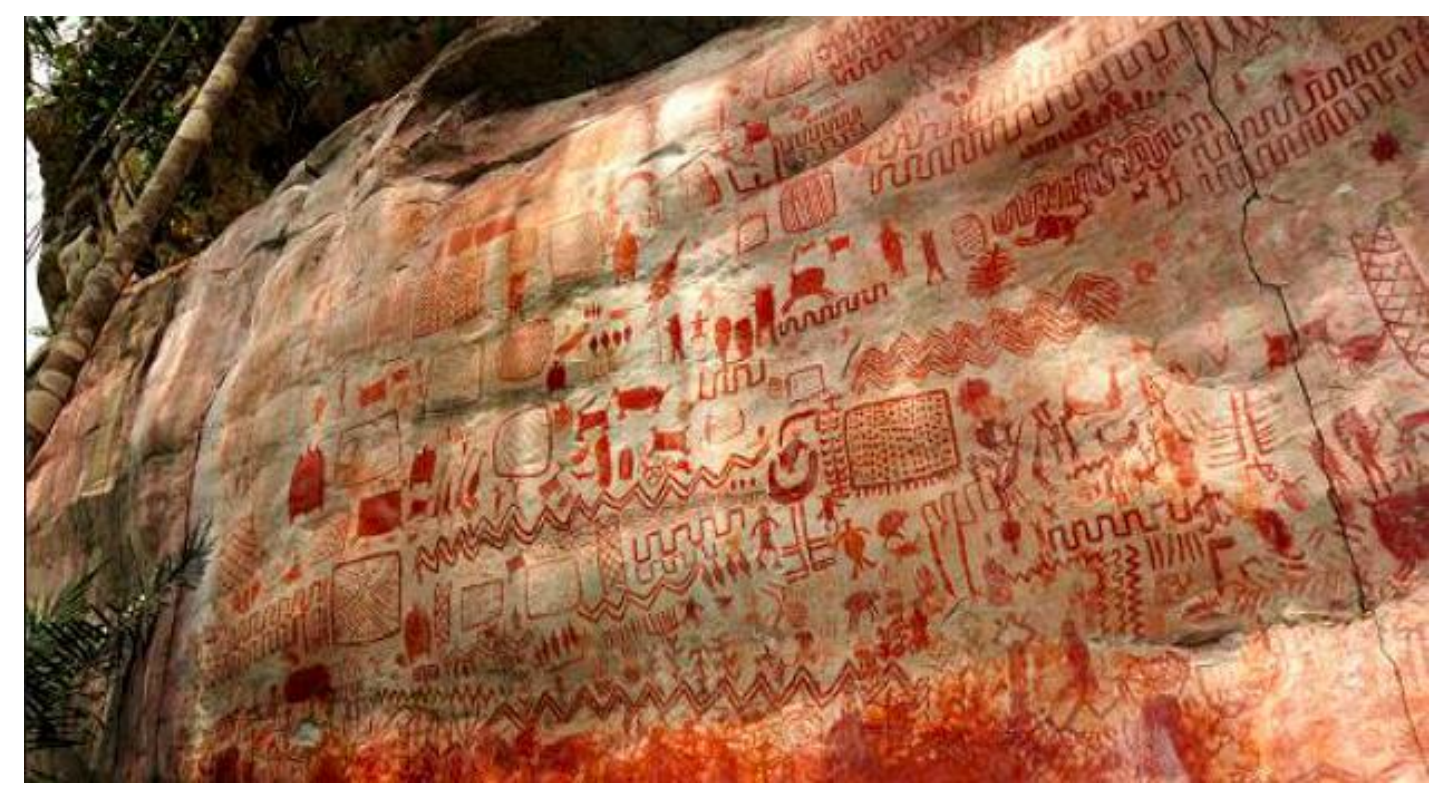

Figura $n^{\circ} .1$ Arte Rupestre Colombiano en el parque nacional de Chiribiquete. Colombia. revista Semana. Disponible en:

https://www.semana.com/nacion/articulo/el-arte-rupestre-escondido-en-el-parque-dechiribiquete $/ 354753$

En ellas se puede apreciar el "modus vivendi" de las comunidades que las realizaron. En estas con la ayuda de dibujos muy sencillos y sin pretensiones artísticas (con un grafismo propio) quedo registrada la forma como se desenvolvía la cotidianidad de estas comunidades, sus temores más inmediatos, sus formas de vida, sus migraciones (algunos de estos grupos eran nómadas, eran trashumantes y viajaban por un territorio amplio en el que tenían asentamientos estacionales fijos), su relación con el entorno (en ellas se apreciaban momentos de la caza o de la recolección de productos del campo de los que dependían para sobrevivir), su sentido de la trascendencia, como los conflictos, las guerras y las luchas por el territorio que determinaron el talante o la condición propia de cada una de estas culturas. En muchos casos su finalidad era desconocida y estaban rodeadas de un cerco de misterio (no existían los grupos humanos para dar testimonio de ello). Pero en general no tenían un sentido limitado, y las comunidades hacían un uso amplio de ellas. Algunas tenían una finalidad mágica, eran una manera ritual de sortear el paso de la vida, del nacimiento a la muerte. Otras las comunidades las utilizaban como una forma de memoria para no sucumbir al olvido, y registraban en ellas gráficamente los detalles de los hechos cotidianos y las acciones de todos los días (los momentos conectados con las formas primarias de obtención del sustento, las 
estrategias de la cacería, el sexo y el nacimiento). De otras se especulaba que tenían un fin erótico o un fin estético y los grupos que las crearon buscaban con ellas engalanar los lugares donde vivían o pasaban las largas y crudas temporadas invernales (Bataille, 1968: 28).

Con el paso del tiempo y los avances propiciados con el desarrollo de la escritura, las artes y las tecnografías propias de cada una de estas formas de expresión, las representaciones fueron cambiando. Uno de los ejemplos más notorios se encuentra en las cartografías y diarios de los grupos de viajeros que iniciaban los procesos de expansión de sus culturas y las búsquedas de nuevas tierras. Ellos fueron consignando gráficamente y en relatos de viaje para las generaciones futuras de viajeros los hallazgos y las vivencias en los lugares que visitaban. Los cartógrafos en mapas y los cosmógrafos en cartas náuticas fueron registrando las experiencias de sus viajes para solventar al regreso a sus lugares de origen y resolver las dificultades que estos acarreaban. En los mapas, los detallados dibujos botánicos y zoológicos, las tablas de regimiento, el conjunto de textos descriptivos les enseñaba a los viajeros que les precedían a distinguir la realidad de la ficción, aquello que pertenece al mito y lo que corresponde a la realidad (Soler, 2004: 55). Otros ejemplos se hallan en las ilustraciones que los alquimistas hicieron de sus procedimientos, del instrumental que utilizaron y de los materiales, en los dibujos anatómicos de los artistas del renacimiento que le enseñaban a sus discípulos el misterio oculto de los seres vivos, en los cuadernos de los artesanos que registraban en detalle las máquinas y los instrumentos que fabricaban, y en el estudio de las posibilidades del cuerpo que hicieron los artistas en el deporte o en las faenas de la guerra.

El hombre es un ser visual. La mente humana funciona de forma gráfica, y busca representar con imágenes los conceptos o los acontecimientos. En el proceso de comprensión de lo realidad inmediata o de los fenómenos particulares el hombre termina recurriendo al uso de imágenes o de representaciones gráficas para analizar los fenómenos y los acontecimientos, organizar y asociar las ideas. Este procedimiento de visualización le permite no solo registrar el conocimiento que ha logrado sobre algo, retener y memorizar la información, seleccionar la información necesaria, sino que le posibilita 
expresar sensaciones, sentimientos e intuiciones sobre la realidad cercana y lejana.

El periodismo no es ajeno a este fenómeno social que propicia la imagen y durante su desarrollo, poco a poco, ha ido incorporando en sus productos informativos imágenes e lustraciones de diverso tipo. En un primer momento como respaldo a la información escrita utilizaron dibujos, mapas, planos, gráficos, esquemas y fotos. En la actualidad, para darle otro aire a la información y una mayor proyección a su función, fueron incorporando las infografías. Este material gráfico no está pensado sólo para atraer y captar la atención del lector o como un elemento decorativo (como algo atractivo o divertido), las infografías les permiten a los lectores complementar lo que el texto impreso les ofrece y tener una visión más global de los fenómenos.

\section{Cultura visual}

Las primeras prácticas comunicativas del niño con el mundo, sus aprendizajes iniciales durante la primera infancia suelen darse a través de los sentidos: sus reacciones a algún estímulo del tacto, del olfato, del oído, del gusto o de la vista suelen ser sus primeras experiencias de vida. En este conjunto la vista ocupa un lugar protagónico, esta supera amplia y rápidamente a los otros sentidos.

La vista llega antes que las palabras. El niño mira y ve antes de hablar. Pero esto es cierto también en otro sentido. La vista es la que establece nuestro lugar en el mundo circundante; explicamos es mundo con palabras, pero las palabras nunca pueden anular el hecho de que estamos rodeados por él. Nunca se ha establecido la relación entre lo que vemos y lo que sabemos. (Berger, 2006)

La psiquiatra Xaro Sánchez (especialista en neurociencia de las artes visuales del Hospital de Mataró en Cataluña) planteaba y se preguntaba, en una columna periodística en el periódico La Vanguardia: "La corteza cerebral de tipo visual es la más extensa, unas cinco veces mayor que la corteza auditiva.... ¿Por qué no usar la vía visual tanto o más que el lenguaje escrito o bablado?"(Sánchez, 2009: 24). 
Por otra parte, se ha demostrado que la visión es el sentido que más ha evolucionado de forma reciente, porque se desplegó más tarde y es el que ofrece mayores posibilidades de desarrollo de modelos que permitan adquirir y transmitir conocimientos

El objetivo fundamental del cerebro visual y el motivo por el cual evolucionó a lo largo de las especies, es porque la visión es la manera más eficaz de adquirir conocimientos del mundo. Los 'animales' que tenemos visión tenemos una opción de sobrevivir porque nos respaldan las necesidades de supervivencia. ${ }^{22}$

"El hombre es un ser vidente, que ve con el pensamiento, que piensa viendo" (Aicher, 2001: 71). La visión en el hombre no descansa, está en continuo movimiento y actividad, aprehendiendo continuamente las cosas y los seres que se encuentran en el círculo cuyo centro es ella misma.

Pero el hecho de que la vista llegue antes que el habla, y que las palabras nunca cubran por completo la función de la vista, no implica que esta sea una pura reacción mecánica a ciertos estímulos (solo cabe pensar de esta manera si aislamos una pequeña parte del proceso, la que afecta a la retina). Solamente vemos aquello que miramos. Y mirar es un acto voluntario, como resultado del cual, lo que vemos queda a nuestro alcance. (Berger, 2006)

Con ella el hombre realiza un análisis profundo, un proceso de decodificación detallado y abarcador. La información que el hombre puede captar por este camino no es necesariamente simple y evidente, puede ser muy compleja, aunque posteriormente no se verbalice, ni se sistematice. Con ella capta el entorno, lo analiza, lo entiende y lo aprehende, se apropia de la información que encierra y puede construir una percepción profunda del mundo próximo que lo circunda.

El objetivo del cerebro visual en el hombre es adquirir conocimiento y mejorar el ya adquirido al máximo (Dice Xaro Sánchez). A través de los ojos el hombre identifica los objetos que le rodean y tiene una dimensión del espacio, recibe datos del medio ambiente, estandariza

\footnotetext{
${ }^{22}$ Conversación sostenida con la Doctora Xaro Sánchez en la Biblioteca del Hospital de Mataró el día 24 de abril de 2008 a las 11:00 a.m. Archivo personal.
} 
los elementos con los que interrelaciona, construye un "mapa" para moverse en él, intelectualiza el medio, construye referencias y categorías y pone a dialogar el cerebro con el mundo. El cerebro le permite al hombre vivir la experiencia del mundo, procesarla, entenderla para incidir y regresar sobre ella (Segundo, 2013, p. 37) (la corteza visual tiene muchas neuronas expertas en analizar sólo la información que encuentran en el entorno que rodea al hombre).

El ser humano tiene mediante los ojos la posibilidad de ver los objetos materiales de la naturaleza visible, pero también dichos órganos son la puerta de entrada de representaciones de los acontecimientos, acciones o cosas inmateriales, intangibles, etc. que, por medios convencionalmente admitidos, se pueden explicar y permiten comprenderlos. (Valero, 2014: 3)

La imagen en su entorno más próximo arrastra al hombre y lo compromete en su dinámica tanto como emisor y como espectador. Sus posibilidades son muy amplias, y variadas.

La vista es veloz, comprensiva y simultáneamente analítica y sintética. Requiere tan poca energía para funcionar, lo hace a la velocidad de la luz, que permite a nuestras mentes recibir y conservar un numero infinito de unidades de información en una fracción de segundo. -Caleb Gattegno, en Towards a Visual Culture, citado por Dondis (1992: 14)-.

$\mathrm{Y}$ es que siguiendo su presencia en todas partes y a todo momento es en palabras de Barnés (2006: 16):

Omnipresente en la vida privada tanto como en la vida pública, la imagen organiza los destinos, hace y deshace los poderes, extiende hasta el infinito las fronteras de lo imaginario y, como colofón, amalgama la realidad, la ficción y la virtualidad (...) desde la esfera del trabajo a la de la educación, del terreno del tiempo libre al de la salud, de la juventud a la edad adulta, acompañando todas las etapas de la vida.

Pero en últimas nuestro interés debe estar enfocado en la cultura visual que no se basa de forma exclusiva en las imágenes como la entendemos en el mundo occidental, porque "En últimas la cultura visual no 
depende tanto de las imágenes como de la moderna tendencia a visualizar o poner en imágenes lo existente" (Mirzoeff, 1998: 6).

Y es que la imagen actual o más bien las imágenes han tenido un tránsito desde sus orígenes cuando se identificaban con pictogramas que crearon el lenguaje textual que daría el paso a la cultura de texto por siglos hasta dar paso al lenguaje de la imagen que enriquecido con el dibujo, el grabado, la pintura, posteriormente con el cine y la fotografía continuo su camino a la cultura de la imagen o mejor de las imágenes que en su rápido desarrollo saltó a una cultura visual que hoy tenemos y que paso inadvertida para todos:

El tránsito de la cultura del texto a la cultura de la imagen fue mucho mas lento que el actual, es decir, el que nos ha llevado de la cultura de la imagen a la cultura visual. Quizá por ello también dio la impresión de ser mucho más traumático, puesto que bubo tiempo suficiente, todo un siglo, para sopesar los pros y los contras, para escuchar las quejas y los reclamos que llegó a suscitar. Por el contrario, de la imagen se ha pasado a lo visual sin que nadie se pronunciará sobre ello, como si se diera por sentado que ambos espacios correspondian a un mismo territorio... (Catalá, 2005: 43).

\section{La infografía: una imagen síntesis}

En la actualidad la proliferación de los medios audiovisuales, "la acelerada expansión y desarrollo de las tecnologías icónicas asociadas a la microelectónica y la informática" (Gubern, 2005: 36), la masiva implementación de internet como nuevo canal de transmisión informativa (Gubern, 2010: 109).

Internet creó una aldea global... La red se convierte en una especie de exposición universal permanente, un lugar compartido sin límites, por su tamaño, más una ciudad que una aldea, pero una ciudad global (Foguel, 2006: 149), las dinámicas que impone la tecnologización y la globalización, propician nuevos modelos de comunicación, cambios notorios en el paisaje audiovisual y en los hábitos culturales de las personas, y en los modos de producción y circulación del conocimiento. En la sociedad "posindustrial e informatizada" se da un cambio sustancial: de una sociedad sedentaria con altas tasas de analfabetismo y caracterizada por una baja densidad icónica se da el paso a una sociedad con una alta 
densidad icónica (Gubern, 1995: 36) en la cual adquiere la imagen un protagonismo muy especial. Y es que como afirma Castañares: "Los cambios que introducen las nuevas tecnologías, admitámoslo, afectan sobre todo a la imagen visual, que adquiere unas modalidades expresivas y de representación diferentes a las que hasta abora conocíamos" (2007: 46).

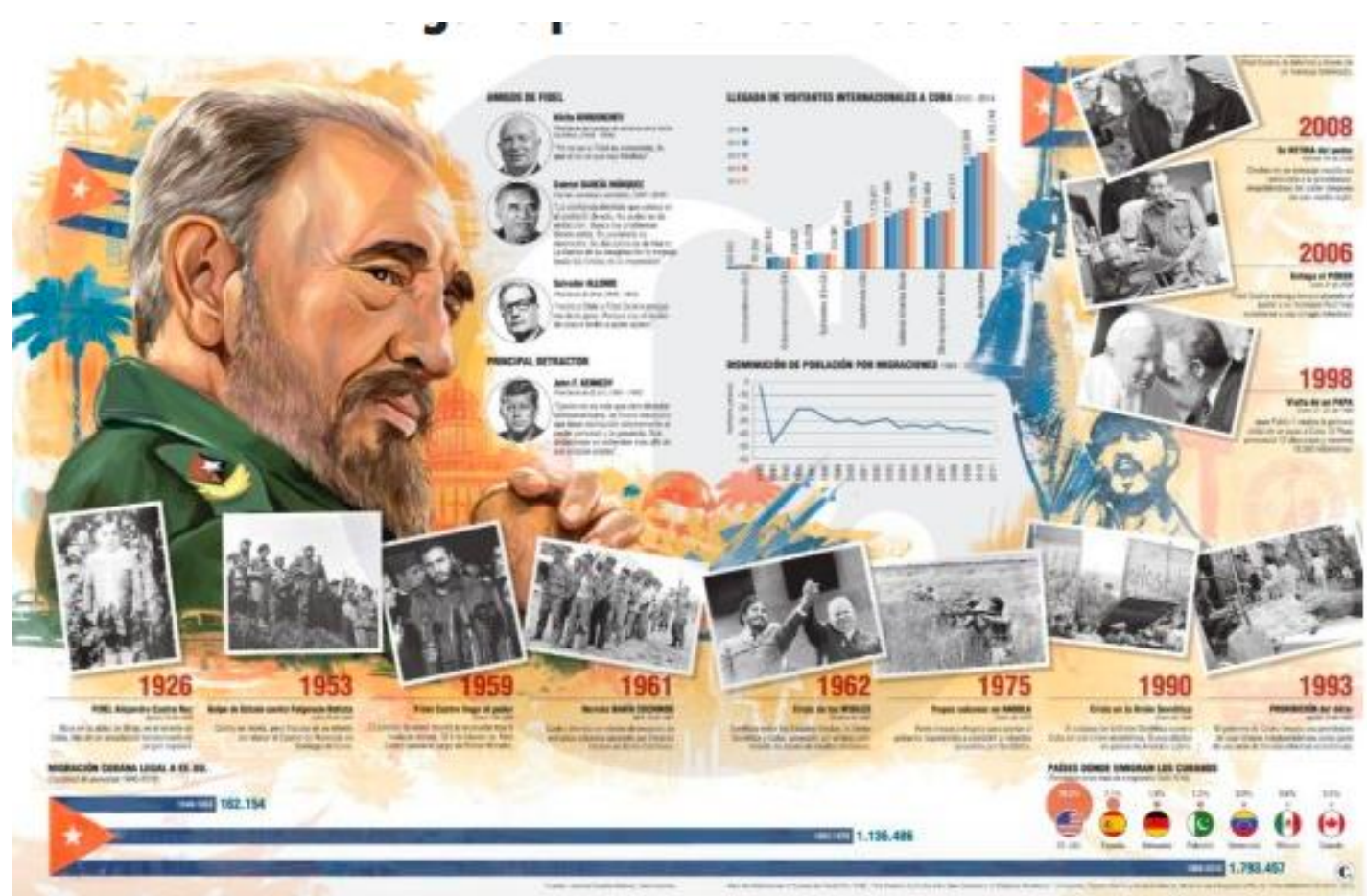

Figura ${ }^{\circ} 2$. El Colombiano gana premio internacional de diseño. Infografía publicada en El Colombiano, Medellín Colombia. Disponible en:

http://www.elcolombiano.com/antioquia/premio-snd-de-diseno-para-departamento-deinfografia-de-el-colombiano-NE5987096

La imagen en occidente, desde Platón, fue identificada con la apariencia y la proyección subjetiva, con la percepción superficial de los fenómenos, con el engaño, con la manipulación. Para la tradición filosófica era "un obstáculo estructural del conocimiento". "El ojo engaña, se ha dicho; el pensamiento es la liberación del engaño. El pensamiento se aparta de lo singular, de lo particular. Encuentra lo general, el orden" (Aicher, 2001: 70). En la actualidad esta percepción ha cambiado, se halla en bancarrota. La sociedad asiste a un cambio de paradigma, a una revolución cognitiva de grandes consecuencias (Gubern, 2010: 31), en la que se rehacen las relaciones entre lo discursivo (la lógica y la racionalidad) y lo visible, la inteligibilidad y la sensibilidad. Las teorías que reflexionaban sobre las formas de producción del conocimiento y discriminaban los sentidos, que concluían que la imagen y la visión eran obstáculos epistemológicos, que eran un camino pasivo hacia el 
hallazgo y la búsqueda de la verdad (eran instancias que confundían y engañaban), se ponen en entredicho. Las nuevas posturas epistemológicas parten de un lugar diferente alejado de la concepción mecanicista y material de la visión, de una visión fisiológica y orgánica del mirar: el pensar también supone el ver. La nueva postura libera la imagen y la recuperan "como ingrediente clave de la nueva relación entre simulación y experiencia cientifica" (Martín-Barbero, 2003: 69).

La época actual es una era post-Gutenberg. Al sistema de comunicación dominado por el pensar orientado a lo "verbal-lógico" (Aicher, 2001: 86), por la valoración excesiva del poder de la palabra (el uso de la palabra sostenía la conciencia cultural), por la mentalidad tipográfica y el orden alfabético, por el texto (como una tecnología del intelecto) y la secuencialidad, le sucede un nuevo orden dominado por el "pensar visual" (Aicher, 2001: 86), por las posibilidades de cognoscitivas de la imagen. "El hombre es un ser vidente, que ve con el pensamiento. Debemos ampliar la cultura del cálculo con la cultura de la visión" (Aicher, 2001: 71).

Además, en la sociedad postindustrial la imagen asume otra naturaleza. Deja de ser una copia: no es la imagen que sólo tiene como opción el poder de ilustrar una idea o reproducir la realidad que le pre-existe, es la imagen que explora las posibilidades que le ofrece la virtualidad, que rompe sus vínculos con la realidad y ella misma se transforma en la única realidad posible. La imagen infográfica, ajena a cámaras y objetivos, es autónoma respecto a las apariencias visibles del mundo físico... la imagen de sintesis nace de un "ojo sin cuerpo" y culmina asi el trayecto bistórico de la imagen en buisqueda de su autonomía absoluta, liberándola del peso y de las imposiciones de la realidad (Gubern, 1995: 39). La imagen deja de ser el efecto de un proceso de re-producción y se muestra como el resultado de un proceso de producción de nuevas realidades.

Como parte de este proceso está el hipertexto. El hipertexto es un sistema informático que permite un recorrido no lineal entre diferentes textos, documentos o materiales gráficos o visuales mediante enlaces (links) que los vinculan entre $\mathrm{si}^{23}$. Como está compuesto de múltiples

${ }^{23}$ El hipertexto es un medio informático que relaciona información tanto verbal como no verbal, al almacenar caracteres, imágenes y sonidos y relacionar los distintos 
cuerpos sin unión secuencial predeterminada, no tiene un eje primario que lo organice y determine el sentido o un centro de lectura posible. En el hipertexto es el lector quien, libremente y con una gran autonomía, desplaza o fija el principio organizador marcando su recorrido entre las lexias a través de diversas trayectorias, bien dentro de la obra o fuera de ella (Calvo, 2002). Con el hipertexto el lector se libera de las condiciones que lo limitan y la hacen pasivo, que en la producción del conocimiento lo sitúan en un lugar secundario. A diferencia del libro donde el lector no tiene la opción de responderle al autor mientras lee el texto, en el hipertexto la lectura se construye desde un diálogo continuo con otros lectores y con otros textos: en la red "la respuesta se une en la pantalla al contenido que la ha provocado" (Fogel, 2006: 150).

Es esta movilidad que le da al lector está el cambio que se da en la cultura: el hipertexto quiebra la constricción de la linealidad propia de la escritura, la rigidez de sus itinerarios, y los sustituye por una estructura de movilidad arborescente (Gubern, 2010: 107), por un modelo de conexiones automatizadas mucho más dinámico y selectivo. La decodificación del hipertexto impone una nueva forma de leer que aflora como una lectura multilineal basada en el establecimiento de una red de conexiones o de asociaciones. La innovación de este método de lectura consiste precisamente en la posibilidad de establecer asociaciones infinitas entre las ideas expuestas en el recorrido transversal que este le ofrece al lector. Con el hipertexto se pasa de la lectura monológica a la lectura como descubrimiento. El texto tenía un solo sentido que el lector debia encontrar. Hoy el texto es un acertijo que hay que descifrar, donde los laberintos de la significación permiten diversos senderos (Gómez, 1999: 82). Este nuevo formato es verdaderamente revolucionario en términos de rentabilidad informativa.

Este proceso no es ajeno el ciberperiodismo cuya evolución en gran medida se ha dado a partir del denominado periodismo visual, que

elementos con facilidad; sus nexos electrónicos unen lexias tanto "externas" a un texto dado (por ejemplo, un comentario a éste por otro autor, o textos paralelos o comparativos), como internas, creando de este modo un texto multilineal o multisecuencial (Calvo, 2002). 
tiene como elemento más representativo la imagen de síntesis ${ }^{24}$. En esta se resume el espíritu de la época y se consolidan las nuevas tendencias en la concepción de la imagen y los cambios en las formas de lectura iniciadas con el modelo instaurado por el hipertexto.

La infografía es una de estas imágenes síntesis. Surge como un mensaje pedagógico y explicativo que facilita la comprensión de la información. Con ella es posible mostrar (re-presentar) el desarrollo de procesos de cierto nivel de complejidad, compuestos por varias etapas y un proceso que supone un desarrollo de una fase inicial a la final donde concluye y se cierra. La infografía es una imagen que no solo reúne los hechos ocurridos, con su uso se pueden visualizar el contexto, antecedentes y consecuencias, y ofrecer de manera esquemática un panorama amplio y abarcador.

No es un conjunto de imágenes dispersas y simplemente ilustrativas. Es una sucesión de imágenes y textos que responden al principio periodístico de la jerarquía, que van de lo importante a lo superfluo, de lo informativo a lo literario (Valero, 1999-2000). Es una combinación ordenada y escalonada de imágenes sintéticas, explicativas y fáciles de entender, y de textos cortos. La infografía está diseñada como un mensaje de tipo analítico que permite establecer jerarquías en los diferentes momentos y un orden en lo ocurrido, en el que se puede apreciar la lógica de la producción de un fenómeno, y se ve representado, en sus relaciones con el hecho estudiado, las causas y los efectos. Está diseñada para ubicar el hecho en el espacio (georeferenciarlo) y en el tiempo (establecer su temporalidad en una línea de tiempo, en una cronología detallada de los hechos) y evaluarlo con todas sus variantes.

Es una herramienta que en manos de los medios periodista le permite organizar la información y hacerla evidente. Para ello dispone del aporte del diseñador gráfico, del diagramador, de los ilustradores, de las posibilidades que le brinda la fotografía y la imagen digital, de los

${ }^{24}$ Como lo confirman los estudios de Juan Antonio Giner (1995), citados por López Hidalgo $(2002,173)$, que señalaban que era precisamente la imagen de síntesis la mejor percibida entre los lectores y que sería el periodismo visual la columna vertebral de los diarios del siglo XXI. 
conocimientos que aporta el programador. Además, con ella el periodista se vuelve un pedagogo que explora las posibilidades explicativas de su discurso, reflexiona sobre el camino más fácil para la comprensión de los fenómenos. Deja de privilegiar la retórica y la poética de la expresión verbal, el valor de la primicia informativa y la titulación para retomar la dimensión analítica del discurso.

La infografía facilita la interacción del público con los medios. La ruta a seguir no está limitada, ni restringida, cada lector puede recorrer su propio camino en la construcción de la información, puede al leer la imagen, "jugar" con variantes e hipótesis abiertas, con otros caminos diferentes a la línea argumental del periodismo tradicional. Además, no es una herramienta que haya agotado sus posibilidades o concluido, que esté en el límite de sus posibilidades. Es una forma de expresión visual y textual que admite variantes y aportes, y que está en proceso de transformación y de consolidación. La evidente y comprometida relación actual con el periodismo de datos es una muestra de ello.

¿Qué demanda para ser leída? Es una manera de informar que requiere de un conjunto de competencias de parte del lector, de un capital cultural específico que tiene que ver tanto con el manejo de las herramientas y los dispositivos tecnológicos, como con el uso de ciertos lenguajes tanto gráficos como escritos (por ejemplo las competencias necesarias para leer mapas, planos o cartografías y orientarse en el espacio con una representación abstracta de la topografía y los accidentes geográficos), con el conocimiento de ciertos símbolos básicos como con el conjunto de indicaciones gráficas que facilitan la orientación y los procesos de lectura de la imagen. La infografía requiere de un destinatario hábil que pueda asumir el juego de la interactividad y asuma el conocimiento como una búsqueda personal.

Este nuevo tipo de lectura asume rasgos de desafio para el perceptor que tiene que crear su propio texto y que al mismo tiempo experimenta un encuentro particular con el emisor, el mensaje y el medio, o sea el ordenador y sus posibilidades de lectura al enfrentarse al texto no lineal que le ofrece la prensa digital. Esto posibilita que el perceptor pueda intervenir de modo más directo en el proceso de comunicación, y que participe más activamente en la 
comunicación al seleccionar la información que requiere a partir de las alternativas que se ofrecen. El perceptor entra asi, en una interacción que lo lleva a colaborar en la elaboración del mensaje que interpreta desde su contexto. (Trujillo, 2002).

Al grupo de destinatarios de la infografía pertenecen los jóvenes y el público tradicional de los medios. Los primeros son nativos digitales y los mayores provienen de la generación anterior que se formaron en otros modelos de sociedad.

Los niños y los jóvenes del siglo XXI son una generación que crece en medio de un acumulado de información que es imposible determinar (está en permanente construcción y desarrollo) y que cuenta con altos niveles de exigencia en relación a la adquisición de conocimientos. Para desempeñarse académicamente y posteriormente en el mundo laboral, los jóvenes necesitan estar al día, tanto en el manejo de los nuevos dispositivos tecnológicos, como en los conocimientos que reclama el mundo del mercado y la producción. Por eso algunos de ellos ven como necesidades primordiales moverse con facilidad entre ordenadores, dispositivos tecnológicos y el entorno que estos han creado además de hablar más de dos idiomas (hoy no basta con el materno y el inglés) para responder a los procesos y las demandas de la globalización. La gran mayoría de ellos navegan por Internet con una propiedad y una soltura que envidian los adultos, se mueven y socializan en un entorno no presencial y asincrónico, son usuarios activos de redes sociales y participan de debates sobre asuntos de la vida pública (temas de la vida ciudadana) a través de estas formas de agrupación.

Sin embargo, muchos expertos en educación y pedagogía reconocen que existe una destreza y una capacidad cultural necesaria en este ambiente a la que en la escuela no le da el lugar y el valor que merece: la nueva visualidad demanda de una mayor experiencia y familiaridad con las imágenes, de la implementación de nuevas habilidades que permitan tanto leer las imágenes como elaborar con ellas mensajes. Los jóvenes necesitan adaptarse a este nuevo entorno telemático, saber moverse en él y para ello necesitan tener ciertas competencias entre las que se encuentran el saber analizar una imagen multimedia (visual y 
sonora), como tener la habilidad de producir mensajes con ellas, componerlas, construirlas o modificarlas, y poder descomponerlas y analizarlas: esta es la "nueva forma de alfabetización" que propone Echeverría (1998: 31):

Aparte de alfabetizar los chavales para el entorno urbano, bay que alfanumerizarlos para el entorno telemático. Ello implica que sepan analizar y construir imágenes visuales y sonoras transmisibles por vía telemática o televisiva, de modo que puedan leerlas, escribirlas y componerlas, y no sólo verlas y escucharlas.

\section{Los nuevos medios: otro panorama}

Si bien hasta no hace mucho estábamos acostumbrados a los medios tradicionales impresos, audibles o televisivos, la llegada de la red, del hipertexto y con ella la de los nuevos medios marca otro panorama para los usuarios de medios de comunicación.

En los medios textuales e impresos, el lector obtenía los datos necesarios que allí se le ofrecían, pero, al comenzar los medios de comunicación a incluir fotografías e imágenes, los lectores sintieron que este nuevo servicio les acercaba más al lugar de los hechos. Por ejemplo, el dibujo de un mapa los ubicaba espacialmente y una fotografía les mostraba detalles que palabras aisladas a veces no podían transmitir. Con la llegada de la infografía a las redacciones de los medios de comunicación, en especial de la prensa desarrollada digitalmente y la televisión, se reconoció la importancia de unir en un nuevo formato la imagen, el texto y el sonido de manera complementaria.

Reconocemos en la infografía una nueva forma de presentar la información (ver Figura n ${ }^{\circ}$ ), en particular cuando se realiza a través de internet. Su informatizada aparición en los medios impresos fue una especie de origen, pero, con el cambio de medio, se transformó dotándose de más y mejores propiedades. 


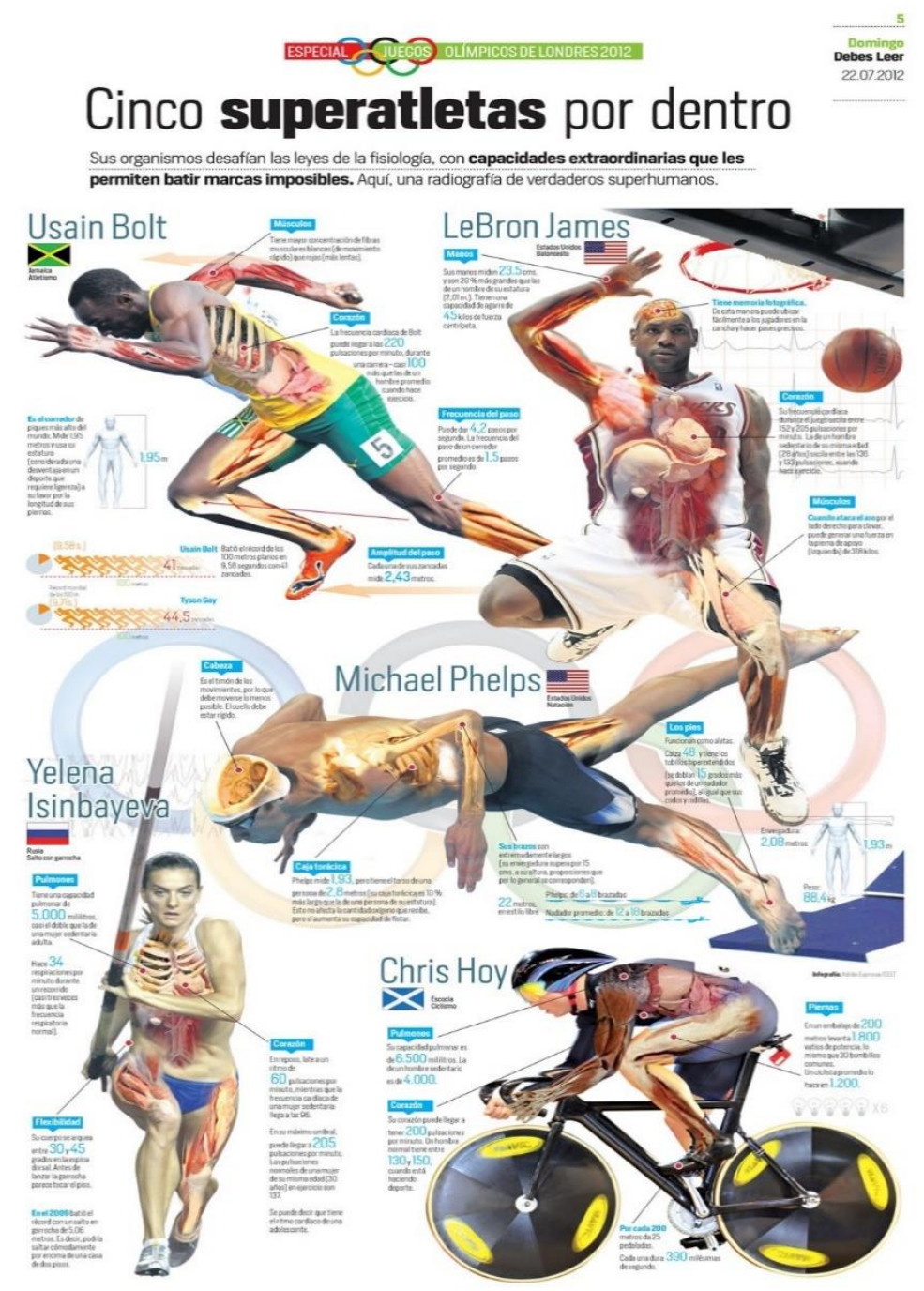

Figura n³. 'Cinco superatletas por dentro', infografía del diseñador Adrián Espinosa y el periodista deportivo Lisandro Rengifo de EL TIEMPO, premiada en la categoría infografía de los Premios de Periodismo del Grupo de Diarios América (GDA). Disponible en: http://www.eltiempo.com/gente/ARCHIVO/ARCHIVO-12976406-0.jpg

La infografía digital, por su parte, es aquella que se realiza en el contexto de la comunicación digital, que además en nuestro caso se puede entender como ciberperiodística, por tanto, puede ser automática y de actualización permanente, o sea, siempre se puede actualizar en el momento en que se produce un nuevo dato relevante.

Los estudiosos de los cibermedios destacan como una de sus características importantes que, gracias a los recursos y herramientas propias de la red, la infografía digital permite niveles de interactividad entre los usuarios, aunque subrayan también el cuidado en el uso y 
reproducción de la imagen para representar acontecimientos presentes, constantes y permanentes.

Por ejemplo, imágenes, mapas, planos, dibujos, esquemas quizás cambian o mejoran considerablemente durante su proceso, método, presentación, soporte, etc. y es la tecnología la que permite que se multiplique hasta formar parte de la cotidianidad de los receptores. Y esta posibilidad es más fácil en el cibermedio.

\section{La imagen: un sistema polisémico}

El significado de una imagen no es atemporal, ni es algo que se da naturalmente, la imagen es un producto social y aparentemente muestra una realidad codificada. La image, aunque es obra de un sujeto, es ante todo una producción cultural y responde a ciertas demandas de la época y la sociedad donde se generó. La significación en la imagen es un proceso mental de asociación y de establecimiento de relaciones o de conexiones en el mundo de la cultura ${ }^{25}$. Los códigos que regulan el significado de la imagen, son acuerdos sociales e históricos y cambian de una cultura a otra. La imagen habla de la época: el contexto general, la situación social, histórica y cultural que rodea la imagen determinan el proceso de significación.

En una imagen pueden existir diferentes órdenes de significación o niveles de significado. El primer orden de significación es la denotación, el significado superficial, el sentido literal de la imagen. El segundo orden es la connotación, los significados asociativos (las cadenas de significados) que rodean la imagen. El significado profundo se origina en el contexto histórico que rodea la imagen y al

25 "Comunicarse es usar el mundo entero como aparato semiótico" (Eco, 1976: 90).

Los signos están conectados entre sí. No son independientes, un signo remite a otro y este a otro, y así hasta el infinito (es un movimiento en espiral en el que nunca se tocan los objetos reales. Por este proceso se transforman en formas significantes). "La comprensión de un signo consiste, después de todo, en la comparación entre el signo aprehendido y otros signos conocidos; en otras palabras, la comprensión es una respuesta a un signo con la ayuda de otros signos. Y esta cadena de creatividad y de comprensión ideológica, que se desplaza de signo en signo bacia un nuevo signo, es unica y continua" -Bajtín, citado por Escamilla (1996)-. 
sujeto, y en la organización social. Las connotaciones pueden hacer relación a varios aspectos: a los contenidos que en el objeto expresan la organización social y la condición de clase; a los contenidos simbólicos que la época le asigna a la imagen; a los sentimientos, afectos, impresiones (de admiración, confianza o desconfianza, inquietud, terror, placer, agrado, escándalo) que la imagen puede despertar; a las emociones estéticas, la percepción de la belleza y del goce estético que puede producir, las evocaciones poéticas y las analogías que la imagen puede provocar, las metáforas que tienen adheridas. Es un universo de sentido que reúne lo más profundo y esencial, lo más "misterioso e indefinible", con lo más inmediato y transitorio: integra los contenidos existenciales que hablan del hombre y sus problemáticas, sus anhelos más recónditos y vitales.

Cuando la imagen denota la lectura que se puede hacer de esta es limitada, y no es expansiva, ni se proyecta sobre otras realidades. Cuando una imagen denota el espectador no busca asociarla con elementos externos a esta, la lectura que esta hace posible es una lectura cerrada: la imagen, es, sobre todo, una prueba objetiva de una realidad que le pre-existe. Sus significados no son múltiples, sus posibilidades se reducen y se ven limitadas: es fundamentalmente monosémica.

El espectador que la evalúa le da más importancia a lo que ésta literalmente pueda mostrar. Su actividad se reduce a confrontar o a constatar lo que ésta muestra con la realidad. En la fotografía, por ejemplo, la denotación es la realidad que la imagen designa directamente, la información de lo que se captó a través de la lente.

La dimensión connotativa, por su parte, se refiere a su aspecto subjetivo, o sea, a los múltiples significados que le puede transmitir al receptor. Cuando una imagen connota tiene varios sentidos, es ambigua o sugiere, y es, ante todo, plural, polisémica. Tiene el poder de desatar una cadena asociativa en el espectador y esta depende de la competencia del intérprete, del capital cultural y de su capacidad interpretativa, de su sensibilidad, su capacidad de imaginar, de sus afectos emociones o sentimiento individuales. Para el caso de la fotografía persuasiva, la dimensión connotativa proporciona la expresividad, la emotividad y el aporte cultural, o sea, lo oculto del mensaje gráfico. 
Sobre este tema Eco (1976: 111) precisa:

Como denotación deberemos entender la referencia inmediata que un término provoca en un destinatario del mensaje.

... La denotación ha de ser la referencia inmediata que el código asigna a un término en una cultura determinada.

...es la suma de todas las unidades culturales que el significante puede evocar en la mente del destinatario.

Así mismo, Santos (1998: 192 y 200) aclara que la denotación incluye niveles de objetividad mayor es decir que aquí se responde a ¿qué dice la imagen?, ¿qué hay en la imagen? y ¿qué representa? Mientras que en la connotación hay más subjetividad y se pregunta por ¿qué me dice la imagen?, ¿cómo me lo dice?, ¿qué me sugiere? y ¿qué me evoca? Y agrega además que:

La lectura denotativa se centra preferentemente en un análisis descriptivo de la realidad icónica. La lectura connotativa será preferentemente la interpretación que de ella se haga. Entre una y otra se da como una ruptura de la objetividad para dar paso a los componentes más subjetivos, más libres, más abiertos.

Sobre esta caracterización elabora la tabla que viene a continuación donde registra la condición opuesta de ambas lecturas.

\begin{tabular}{|c|c|}
\hline Denotación & Connotación \\
\hline 1. Objetiva & 1. Subjetiva \\
2. Convergente & 2. Divergente \\
3. Literal & 3. Arbitraria \\
4. Informativa & 4. Interpretativa \\
5. Patente & 5. Latente \\
6. Obvia & 6. Obtusa \\
7. Explícita & 7. Implícita \\
8. Visible & 8. Oculta \\
9. Práctica & 9. Mítica \\
10. Superficial & 10. De fondo \\
11. Cerrada & 11. Abierta \\
12. Cognoscitiva & 12. Emotiva \\
\hline
\end{tabular}




\begin{tabular}{|c|c|}
\hline 13. Fáctica & 13. Persuasiva \\
14. Lógica & 14. Psicológica \\
15. Acción lógica & 15. Contemplación \\
16. Primaria & 16. Secundaria \\
17. Querida por emisor & 17. Querida por receptor \\
18. Representación & 18. Evocación \\
19. Clara & 19. Desvaída \\
20. Concreta & 20. Abstracta \\
21. Dicho & 21. Sugerido \\
22. Simple & 22. Compleja \\
23. Codificado & 23. Libre \\
24. Se ve "con los ojos" & 24. No se ve "con los \\
25. Monosémica & ojos" \\
& 25. Polisémica \\
\hline
\end{tabular}

Tabla No. 1. Características bipolares de la lectura de las imágenes (Santos, 1998: 200).

Por eso la reacción que el intérprete tienen cuando accede a la presentación de la noticia con todos sus componentes, oscila entre dos momentos: en un primer momento, percibe objetividad, una imagen literal, informativa, superficial, práctica, concreta/o simple. En su primer acercamiento ve "con los ojos", establece una relación rápida con la imagen según los códigos culturales que la determinan. En este primer nivel la prioridad es establecer un análisis de tipo descriptivo, que dé cuenta de lo que la imagen muestra.

En un segundo momento, cuando la imagen connota hay una sumatoria de unidades culturales que le permiten al intérprete recordar y relacionar desde su propia subjetividad, por eso es arbitraria, diferente, interpretativa, emotiva, compleja y, al contrario de la anterior, no se ve solamente "con los ojos". Los sentidos que en ella se activan dependen de la participación (de la sensibilidad, de la capacidad de interconectar aspectos y vincular sentimientos o emociones con lo percibido - de su capacidad de dejarse impresionar y abandonar las demandas de la racionalidad-) que posea el lector. 


\section{La infografía desde la lingüística y la semiología}

Ahora, si analizamos la noticia y el reportaje desde el lenguaje, podemos ver cómo se comportan cuando son presentadas como infografía digital. Para ello es importante retomar los aportes de la lingüística para el estudio la expresión escrita y la semiología para el análisis de la imagen (visual y auditiva) y de los otros recursos gráficos ${ }^{26}$.

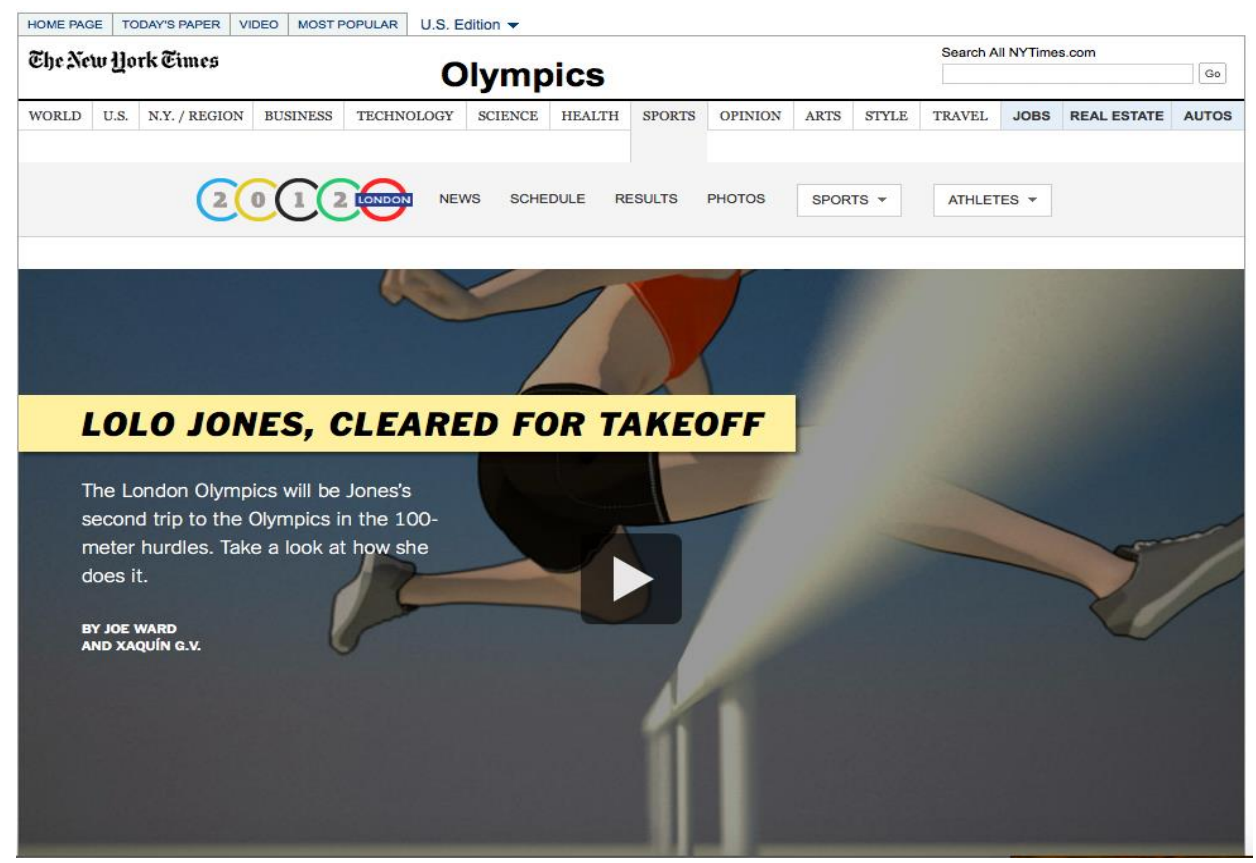

Figura $\mathbf{n}^{\circ}$ 4. Instante de 'How to win: The Hurdles. Lolo Jones, Cleared for Takeoff'. Disponible en

http://archive.nytimes.com/www.nytimes.com/interactive/2012/07/18/sport s/olympics/lolo-jones-cleared-for-takeoff.html? $\mathrm{r}=0$

26 "La lengua es un sistema de signos que expresan ideas y, por lo tanto, comparable a la escritura, el alfabeto de los sordomudos, los ritos simbólicos, las formas de cortesía, las señales militares, etc. Es posible concebir asi una ciencia que estudie la vida de los signos en el seno de la vida social; tal ciencia formaria parte de la psicología socialy, por consiguiente, de la psicología general. La llamaremos semiología (del griego semeion, "signo"). Esta ciencia nos enseñará en qué consisten los signos, qué leyes los rigen" (Saussure, 1972, p. $60)$.

"La semiología se ocupa de "cualquier cosa que pueda ser concebida como signo" (Eco). Su centro de interés es el mundo de lo extralingüístico, los sistemas de signos diferentes al lenguaje hablado o escrito, cualquiera que fuere la sustancia y los límites de estos sistemas (Barthes, 1971: 13). Su objeto de estudio es el conjunto de sistemas semióticos que forman el referente mundo y que son manifestación del sentido humano (que poseen significación para el hombre). 
Acudir a estas disciplinas tiene un doble objetivo: uno general, constatar cómo el mundo tiene sentido y responder a la pregunta por el qué y el cómo significa lo que el hombre lee, lo que percibe, lo que siente. Y otro particular, evaluar en caso del periodismo y la infografía cómo se construye el sentido, si es monofónica o polifónica, qué valor se le confiere a la imagen y qué función se le asigna al texto (González, 2002: 9). Además, como la infografía es un documento cultural y el periodismo una práctica profesional vigente, una manera de entender la historia reciente, el logro de este objetivo es en último término una profundización sobre la cultura actual, una manera crítica de reconocer e identificar los signos sociales y la sociedad que los produce. Así lo refiere González: "Toda producción de sentido es necesariamente social, por lo que no puede describirse ni explicarse de manera satisfactoria un proceso significante sin hacer explicitas sus condiciones sociales productivas" (2000: 29).

Las nuevas tecnologías de la imagen introducen en la cultura nuevas maneras de representar, comunicar, narrar, diseñar o simular, están acompañados de nuevos dispositivos de memoria, nuevas formas de pensamiento y de percepción.

Si estudiamos la infografía digital como un conjunto de relatos descriptivos y narrativos, teniendo en cuenta las diversas formas de expresión que en ella se concentran (el material textual, los vídeos, audios, los hipertextos que activa) con sus características, para llevar a cabo un estudio completo que dé cuenta tanto del sentido de los signos como del contexto, del orden de los elementos como del papel que cumple el intérprete es necesario retomar la manera como la semiología analiza los distintos campos de relación: la relación del signo con el objeto, del signo con el mismo y con otros signos (con el conjunto), y con el intérprete. La semántica se ocupa del estudio del sentido, la sintaxis, del orden de los elementos en el conjunto, y, la pragmática, de las intensiones del emisor y las reacciones del receptor, del uso que los intérpretes hacen de los mensajes, como de los factores contextuales que intervienen en la emisión de los signos.

La semántica se ocupa del estudio del significado de las expresiones del lenguaje, de los signos (o los textos elaborados) y los objetos a los que se refieren (que denotan o pueden denotar). Se ocupa de las relaciones 
de correspondencia (que significado corresponde cada significante). En el estudio de la infografía la semántica está relacionada con los contenidos de cada lenguaje -escrito, visual, audible y un cuarto que se relaciona con las características propias de la red, el hipertextual-, y por supuesto cada uno de ellos tiene un significado y una significación diferente.

La sintaxis se ocupa de los signos que componen el mensaje y de las relaciones que establecen entre ellos, de la posición que tienen en el conjunto como de las conexiones, las combinaciones de los signos y sus transformaciones. Se ocupa de las relaciones de dependencia entre los signos, de identificar cuáles son dominantes y cuáles son subordinados. En la lengua hablada o escrita, alude al estudio de las reglas que coordinan la palabra o una secuencia de ellas que en conjunto forman una unidad dentro de la estructura jerárquica de una oración. Su función es establecer tanto las reglas sintácticas (de las reglas de formación de signos), como las reglas de transformación. En "el pensar pictórico" procede de otra manera. La lectura de la imagen "no es lineal" como el mensaje escrito. El lector "ve superficies, imágenes, mapas y diagramas. No saca conclusiones, sino que ve conexiones, relaciones, referencias, analogías" (Aicher, 2001: 68). En estos mensajes la sintaxis "estudia los sistemas de signos en su estructura formal regulando qué combinaciones son correctas y cuáles no" (Blasco, 1999: 81).

En la infografía la sintaxis se encargaría de cuidar de las reglas que le impone cada forma de expresión (imagen, sonido o texto, por ejemplo) para hacer el mensaje más comprensible al público, de las convenciones que le permiten construir oraciones y relatos de forma coherente en cualquiera de los sistemas de significación que emplean, de los vínculos, de las conexiones que establecen entre ellas, como de los recorridos posibles en el espacio de la imagen que realiza el lector.

El sentido no es estático se construye sobre una dinámica. El significado que se le puede dar a una imagen depende del contexto y de la posición del intérprete. El intérprete es un ser social y la lectura que él realiza está determinada por las condiciones y las circunstancias personales que lo constituyen como sujeto (su personalidad, sus deseos, sus afectos, sus sentimientos, su pasado personal), y por la 
cultura de la que forma parte, por su condición de clase, su edad, el género al que pertenece, las instituciones de las que participa, etc. De un lado, el ver no es un acto mecánico, no es meramente un logro cerebral, es también un logro cultural. Vemos lo que la cultura no presenta como digno de ser visto... nuestro cerebro, nuestra conciencia, selecciona y reduce la mirada a aquello que queremos ver", de otro, "lo que vemos es comparado con datos almacenados en nuestro cerebro que, a la vez, es la sede de nuestra memoria; vemos sobre el trasfondo de nuestro saber (Aicher, 2001: 63).

La pragmática estudia esta relación: se ocupa de las condiciones generales del uso comunicativo del lenguaje, de las contribuciones del contexto al significado ocasional de un signo, de los aspectos relacionados con la psicología del emisor y del intérprete, con la personalidad y el carácter del usuario del signo (los motivos, los fines, las relaciones, las disposiciones, etc.). De la aplicación y el efecto de los signos en los destinatarios, de las competencias que cada uno tiene y el alcance de su interpretación, y de las relaciones de uso del signo.

La pragmática tiene como objeto de estudio las condiciones físicas, sociales y psíquicas que deben reunir los usuarios del signo para que la comunicación sea efectiva (que facilita o dificulta la interpretación y la apropiación del sentido), de las circunstancias de las que se vale el hablante para ayudar a la comprensión de un mensaje, de las contribuciones extralingüísticas al significado e interpretación particular de las emisiones.

En el estudio de las infografías la pragmática facilita el análisis de las condiciones de recepción, de los usos de que de estas hacen los diferentes públicos. Permite un análisis detallado del capital cultural y audiovisual que poseen los usuarios, de sus competencias, del lugar desde dónde estos leen las imágenes (de las expectativas, valoraciones y preferencias), y, en un plano más general, hace posible construir una tipología tentativa de los diferentes tipos de lectores (según su formación, edad, destrezas en el manejo de la tecnología, creatividad y capacidad de navegar por la red, etc.).

Además, permite evaluar en el proceso de recepción las interferencias que impiden o facilitan la comunicación, determinar las lecturas 
desviadas y las distorsiones que se dan en el manejo de la información que contienen las imágenes.

\section{A manera de conclusión}

La infografía sintetiza la información en formatos visuales de fácil comprensión que los aproxima a la actualidad noticiosa de una manera tranquila, amena y muy pedagógica.

La información que proporcionan la infografía y la visualización de datos es muy importante para las actuales audiencias, pero llega de manera especial a las generaciones más jóvenes. A una generación que ronda hoy entre los 15 y 35 años, y que ha sido denominada la generación de las pantallas, por su capacidad de almacenamiento, análisis, codificación y decodificación de información lo que permite su fácil acercamiento a las propuestas visuales.

La población joven y media está más cercana al uso de lenguajes visuales porque prácticamente han crecido en contacto con pantallas de todo tipo (televisores, ordenadores, videoconsolas, móviles y tabletas) que han sido participes de su desarrollo educativo. Además su vida está marcada por el uso de sistemas de entretenimiento que incluyen, también, el uso permanente de los anteriores dispositivos con características que facilitan su usabilidad y accesibilidad.

La infografía o la visualización de datos tienen enormes posibilidades didácticas en cuanto a información o documentación se refiere, y esto facilita, en los medios, la posibilidad de brindarle al público experto y al no especializado informaciones de todo tipo, de presentarle temas complejos como la guerra, amenos como el deporte o que exigen conocimiento especializado como la ciencia y la tecnología.

La infografía o la visualización de datos tiene la capacidad de aclarar y aumentar los conocimientos obtenido a través de otras formas de presentación de la información, pero esta se convierte en un referente importante para ampliar las nociones sobre diversos temas. La infografía digital, además de ser una herramienta informativa, es un 
recurso didáctico que permite aclarar temas de diversa índole entre las audiencias.

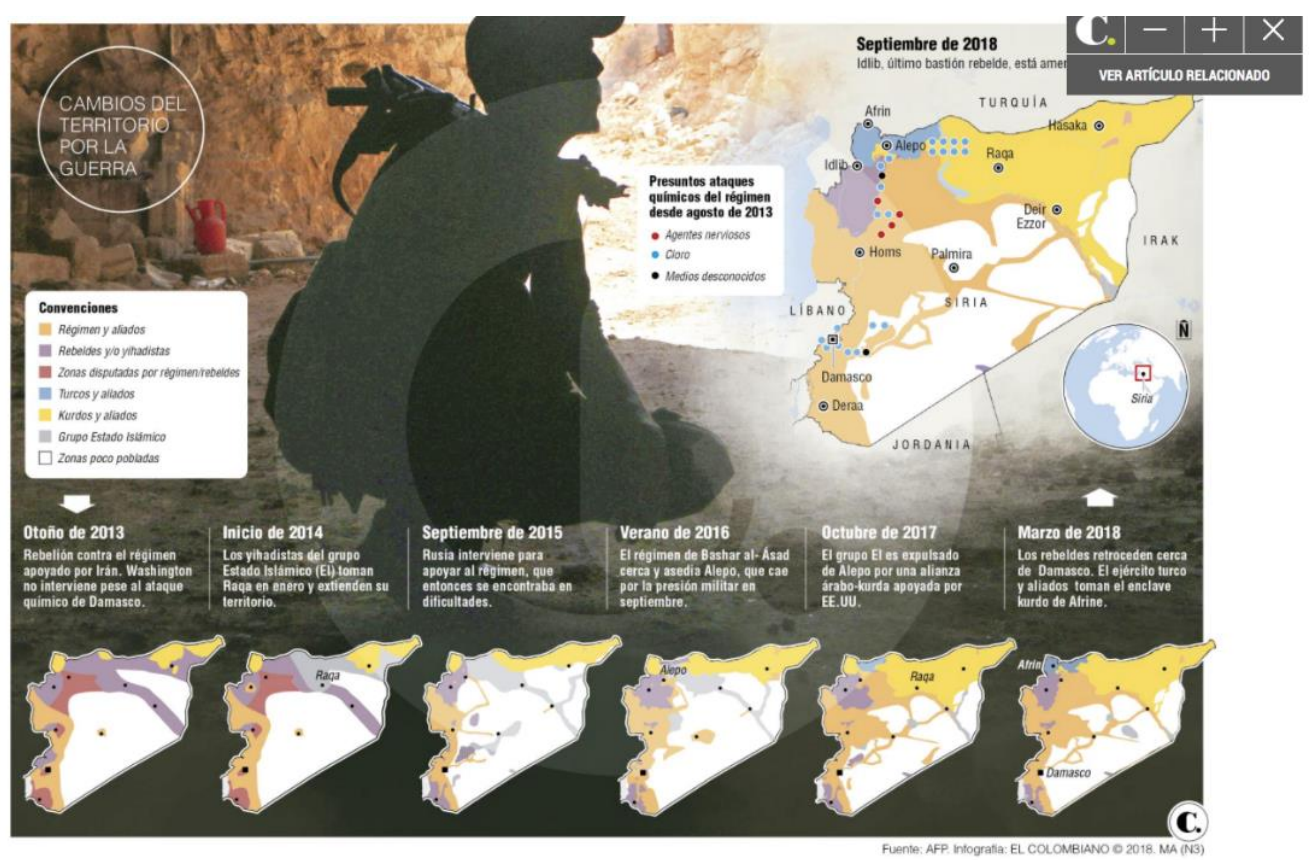

Figura $\mathbf{n}^{\circ}$ 5. Siria bajo amenaza química. Infografia de El Colombiano. Disponible en: http://www.elcolombiano.com/multimedia/infografias/idlib-siria-bajo-amenazaquimica-YM9295414

La información de servicio encuentra en la infografía digital una herramienta idónea que permite brindar información clara y de carácter universal como, por ejemplo, la relacionada con la protección de quienes viven en medio de una guerra, pues permite a los intérpretes de diferentes culturas entender a través de simulaciones o recreaciones de los hechos, la forma de reaccionar en un algún momento. Y en el caso del deporte o el periodismo de aventura genera un alto interés entre las audiencias: sus posibilidades descriptivas le permiten a los lectores imaginar o vivir las situaciones y captar la dimensión de lo ocurrido en escenario deportivo.

En efecto comprobamos, como decía Saussure, que la semiología y su estudio de la vida de los signos, son un aporte para fundamental para el periodismo y para entender la dinámica en la vida social. Esta es una herramienta que facilita el acercamiento a estos nuevos formatos, a comprender los códigos que determinan la elaboración y la lectura de las imágenes en las sociedades actuales, y finalmente es un primer paso para el acercamiento a las audiencias. 


\section{Referencias bibliográficas}

Aicher, O. (2001). Analógico y digital. Barcelona: Gustavo Gili

Barnés, J. S. (2006). ¿Qué son las imágenes? Interpretaciones y aplicaciones. Salamanca (España): Universidad Pontificia

Barthes, R. (1971). Elementos de semiología. Madrid: Alberto Corazón

Bataille, G. (1968). Las lágrimas de Eros. Córdoba (Argentina): Signos

Berger, J., et. al. (2006). Modos de ver. Barcelona: Gustavo Gili

Blanchot, M. (1976). La risa de los dioses. Madrid: Taurus

Blasco, J. L., et. al. (1999). Signo y pensamiento. Barcelona: Ariel Filosofía

Calvo, A. (2002). Lectura y escritura en el hipertexto. Espéculo. Revista de estudios literarios. Universidad Complutense de Madrid. Recuperado ele 28 de septiembre en: http://www.ucm.es/info/especulo22/numero/hipertex.html

Castañares, W. (2007). Cultura visual y crisis de la experiencia. CIC Cuadernos de Información y Comunicación. Vol. 12, pp. 29-48

Catalá, J. M. (2005). La imagen compleja. Barcelona: Universidad Autónoma

Dondis, A. (1992). La sintaxis de la imagen. Introducción al alfabeto visual. Barcelona: Gustavo Gili

Echeverría, J. (1998). La escuela distal. Comunicar, 10, pp. 27-31

Eco, U. (1976). La vida social como sistema de signos. In Eco, U., et. al. Introducción al estructuralismo. Madrid: Alianza 
Escamilla, J. A. (1996). La lingüística y la semiótica frente a los hechos del lenguaje. Alegoría vol.1 (1) pp. 9-27

Fogel, J. F. \& Patiño, B. (2007). La prensa sin Gutenberg. Madrid: Punto de lectura

Gómez, B. y Castillo, M. (1999). Teoría y Didáctica de la Literatura. Cuadernos Pedagógicos, 9, pp. 81-103

Gonzalez, M. (2002). Semiótica crítica y crítica de la cultura. Barcelona: Anthropos

Gonzalez, C. (2000). La cultura desde el punto de vista semiótico. In Piccini, M. et. al. (coord.). Recepción artística y consumo cultural. México: Instituto Nacional de Bellas Artes

Gubern, R. (1995). Las nuevas fronteras de la imagen. Claves de razón práctica. 58, diciembre, pp. 36-43

Gubern, R. (2000). El eros electrónico. Madrid: Taurus

Gubern, R. (2010). Metamorfosis de la lectura. Barcelona: Anagrama

Martín-Barbero, J. (2003). Figuras del desencanto. Número, 36, marzoabril, pp. 66-71

Mirzoeff, N. (1998). Visual culture reader. Nueva York: Routledge

Ramonet, I. (2001). La tiranía de la comunicación. Madrid: Temas de Debate

Ramonet, I. (2002). Revolución digital, globalización y ética. In VVAA. Cine, cultura y nuevas tecnologías. La Habana: Unesco

Sánchez, X. (2009). ¿De qué sirve la asignatura de plástica? Artículo de opinión, La Vanguardia, 25 de marzo. Recuperado el 28 de septiembre de: http://blogs.lavanguardia.com/ctrlaltsupr/¿de-que$\underline{\text { sirve-la-asignatura-de-plastica }}$ 
Santos, M. A. (1998). Imagen y educación. Buenos Aires: Magisterio del Rio de la Plata

Saussure, F. (1972). Curso de lingüistica general. Buenos Aires: Losada

Segundo, M. A. (2013). Mirar a lo lejos: pasos hacia una antropología de la mirada. Cuicuilo, 56, enero-abril, pp. 35-52

Soler, I. (2004). Los ojos del cartógrafo. Revista de Occidente, 280, septiembre, pp. 48-67

Trejo, R. (2002). Internet es el futuro. Telos, 51, segunda época. Abriljunio. Recuperado el 28 de septiembre de: https://telos.fundaciontelefonica.com/telos/articulocuaderno.asp Q, idarticulo $=6 \& \mathrm{rev}=51 . \mathrm{htm}$

Trujillo, M. H. \& Contreras, F. R. (2002). Periodismo digital y discurso científico: nuevos modelos para el siglo XXI. Razón y Palabra, 27, junio-julio

Valero, J. L. (1999-2000). La infografía de prensa. Ámbitos, revista andaluza de Comunicación. No. 3 y 4. Recuperado el 28 de septiembre de: https://issuu.com/ambitoscomunicacion/docs/revistacomunicacion-ambitos-03-04

Valero, J. L. (2001). La infografía, técnicas, análisis y usos periodísticos. Barcelona: Universidad Autónoma

Valero, J. L. (2014). La visualización de datos. Ámbitos. Revista Internacional de Comunicación. 25, julio-diciembre. Recuperado ele 28 de septiembre de: http:/ / www.redalyc.org/articulo.oa?id=16832256009

Vitta, M. (2003) El sistema de las imágenes: estéticas de las representaciones cotidianas. Madrid: Paidos Ibérica. 


\title{
La infografía: un lenguaje multimedia adecuado a las nuevas narrativas
}

\author{
Francesc Morera Vidal ( $\subset$ ). Escuela Massana (UAB), UOC y \\ Escuela Municipal de Arte de Tarrasa (España). \\ francescmorera@gmail.com
}

Resumen. En este texto se analizan las características que hacen de la infografía un producto y un lenguaje apto para enriquecer las nuevas narrativas. La infografía, síntesis de lenguajes, se adapta a la perfección al medio digital y deviene un gran aliado en las comunicaciones que se producen en este entorno y que se han venido en llamar nuevas narrativas. Hay dos razones fundamentales por las que la infografía encaja a la perfección en los formatos de estas nuevas narrativas. La primera, si consideramos la infografía como un producto elaborado cerrado, se adapta al medio digital de manera idónea y goza de un estatuto privilegiado en su incorporación como ente vinculado a las nuevas narrativas. La segunda de las razones es más difusa y tiene que ver con la incorporación del lenguaje infográfico — síntesis de lenguajesen la forma en que se desarrollan las nuevas narrativas. El lenguaje infográfico aparece o se suma a la narración en múltiples formas. Su virtud de ordenar el contenido es determinante.

Palabras clave: Infografía; nuevas narrativas; síntesis; multimedia; interactividad. 


\section{Narración, relato}

T A PALABRA comunicación es sinónimo de interacción y Lentonces implica "transformación, cambio, movimiento" (Aparici y García, 2017: 29). Efectivamente, el acto comunicativo es en dos direcciones, desde el emisor al receptor y la respuesta de éste al primero. El contrato comunicativo va más lejos que una sencilla transmisión de datos.

"La comunicación nos permite poner a todos los que participan en una relación entre iguales" (Aparici y García, 2017: 29). Y adquiere todo el sentido en la comunicación por Internet, donde cada nodo ${ }^{27}$ actúa, a priori, con iguales posibilidades de alcance de público y éste, a su vez, se convierte en emisor en cuanto interactúa. En la telaraña de conexiones, un nodo sólo adquiere un desfase cuantitativo (que no cualitativo) en el sentido de previa notoriedad o poder de convocatoria y aplicación de estrategias de poder que requieren recursos técnicos y humanos. El resto de interacciones parten de la misma condición de igualdad.

Alli donde exista alguien interesado en 'contar una historia' habrá un narrador, y la consecuencia de esta voluntad podrá ser definida como 'narración'; alli donde haya alguien interesado en 'escuchar la historia' que este narrador tiene que contar, habrá un narratario que cerrará el círculo de la interpretación, el bucle pragmático de la comunicación. (Sánchez, 2006: 9)

El acto comunicativo de narración y escucha es propio del ser humano y a lo largo de la historia han cambiado los canales y los medios pero siempre, donde ha habido un narrador ha despertado interés en una audiencia. Así pues, la voluntad de narrar y el atractivo de la escucha forman un binomio natural y habitual. Como ya advirtió Aristóteles, las narraciones causan placer: "Lo maravilloso es, por cierto, causa de placer, como se deduce por el hecho de que todos relatamos una bistoria con agregados, en

\footnotetext{
${ }^{27}$ Usamos la terminología "nodo" para designar el punto donde se conecta el usuario, ya sea productor o consumidor de información. Así, no designa sólo al terminal físico, sino que abarca también a la acción que realiza, ya sea humana o robotizada.
} 
la creencia de que ofrecemos un deleite a muchos oyentes." (Aristóteles, 2005: 89. 1460a).

Este placer que provoca la narración, en los dos sentidos, se acentúa en la disposición propia del ser humano y su necesidad de saber: "[...] el propio movimiento de la narrativa está guiado por el placer, bajo la forma de 'epistemofilía' (deseo de saber): queremos descubrir secretos, saber cómo acaba, hallar la verdad." (Sánchez, 2006: 55). El acto narrativo ha tenido numerosas apariencias y se ha ido adaptando a la sociedad, su avance cultural y, por supuesto, a los medios por los que se ha transmitido. Desde las pinturas de las cuevas prehistóricas, cuyas propiedades narrativas parecen evidentes, aunque no sepamos el sentido último, se han desarrollado múltiples manifestaciones de relatos, orales, visuales y escritos hasta llegar a formas multimedia en las que se sintetiza más de un lenguaje para la transmisión del contenido.

\section{Las Tecnologías de la Información y la Comunicación (TIC) y la narración. Nuevas prácticas}

Si hay un medio en el que la suma de lenguajes no sólo es posible sino que ofrece una amplia variedad de combinaciones entre ellos es Internet $^{28}$. La conectividad como base de la comunicación, pero con tecnologías de producción y recepción en constante desarrollo, permiten generar nuevos modos de narración. "La perfección del código [binario] triunfa y culmina en la transmisión del mensaje". (Metz, 2002: 61).

Las tecnologías de la información y comunicación (TIC), desde 1990 con la aparición de la World Wide $W e b^{29}$ en Internet y la expansión de su uso, han propiciado un cambio notable en las relaciones humanas y han afectado a todos los ámbitos: sociales, políticos, económicos, culturales y cualquier manifestación entre pares y también ha cambiado las dinámicas de las comunicaciones en todos sus aspectos. La web no es un medio más, es un metamedios, un medio de medios, genera nuevas formas y

\footnotetext{
${ }^{28}$ La definición de Internet como conjunto descentralizado de redes de comunicación interconectadas de alcance mundial da una buena idea de las posibilidades de esta conectividad: interconexión a escala global.

29 Protocolos de acceso y comunicación basados en las características del hipertexto.
} 
experiencias de comunicación, se apropia de lenguajes de otros soportes (texto, audio, imagen en movimiento) y además les otorga características propias. (Quiroga, 2016: 285).

El hipertexto y sus posibilidades han cambiado la lectura "pasiva" convencional, en los medios analógicos, por una lectura "activa" y está provocando de manera creciente su participación, con la consiguiente expansión de las historias en múltiples medios, lo que genera nuevas prácticas y conductas activas de exploración de contenidos por su multisecuencialidad en las audiencias. (Quiroga, 2016: 284).

El sujeto que emite y a su vez es receptor de otros emisores quedó definido en 1980 por el destacado futurólogo Alvin Toffler, que introdujo formalmente el término prosumidor (prosumer en inglés) en su libro La tercera ola. Prosumidor es un acrónimo que procede de la fusión de dos palabras: "productor" y "consumidor". El concepto fue anticipado por McLuhan ${ }^{30}$ y Barrington Nevitt en 1972 al adelantar que la tecnología electrónica permitiría al consumidor asumir los dos roles de productor y consumidor de contenidos.

Un concepto parecido al de prosumidor es el de emerec, síntesis de "émetteur" y "récepteur" que propone Cloutier en 1973 y que afirma que "los emerec entran en interacción con otros emerec a través de cualquier medio, estableciendo asi relaciones entre iguales." (Aparici y García, 2017: 74)

Las TIC se fundamentan en la capacidad de procesamiento de información: almacenar, calcular y transferir.

Un dispositivo digital puede reconocer dos estados: On y Off, trabaja en código binario y toda la estructura, por muy ampliada y sofisticada que pueda llegar a ser, responde a esta premisa inicial de funcionamiento. Para interactuar con el usuario, el procesador se sirve de programas. Un programa es una serie lógica de funciones

\footnotetext{
30 "La automatización no afecta solamente a la producción, sino a todas las fases de consumo y comercialización; en un circuito automatizado, el consumidor se convierte en productor, del mismo modo que el lector de la prensa telegráfica se hace sus propias noticias o, simplemente, es sus propias noticias." (McLuhan, 2005: 354). La primera edición del libro de McLuhan, Understanding media, es de 1964.
} 
elementales en las que los términos del problema (input) están exactamente definidos. Realiza cuatro funciones principales: operaciones aritméticas, comparaciones, memorización y transferencia de datos.

Los entornos digitales tienen las siguientes propiedades esenciales, según Murray (en Sánchez, 2006: 15³1): a. secuenciales, b. participativos, c. espaciales y d. enciclopédicos.

Nos detenemos a analizar estas características del entorno digital, puesto que es en este medio donde se encuentran las circunstancias específicas para la producción y consumo de las nuevas narrativas. En esencia, en estos entornos se potencia la interactividad, la participación del usuario con el producto. En los entornos analógicos, la interactividad era más reducida $y$, por ejemplo, en un libro se limitaba al paso de la página o páginas para acceder a información de otra página.

Los entornos digitales son secuenciales en el sentido de orden en la aparición de la respuesta del ordenador (normalmente a través de la pantalla) y, por tanto, recoge la característica del sentido de la vista de secuencialidad o linealidad en la percepción en contraposición a la globalidad del sentido del oído en el que actúa como envolvente. Aún así, el sonido se produce linealmente.

En el entorno digital se alienta la participación del usuario, de la voluntad del mismo se produce la respuesta. No es un consumo audiovisual pasivo, como por ejemplo el cine, sino que el dispositivo permite al usuario elegir diferentes opciones de continuidad o bien se desarrolla respondiendo a los impulsos del usuario según cada acción propuesta.

En el medio digital se recrean espacios en donde el usuario se puede mover, eligiendo itinerarios, a diferencia de los medios lineales libros, películas- en los que se presenta el espacio como una descripción lineal, ya sea manifiesto o evocado. Esta característica los hace espaciales, interactuamos en y con el espacio.

${ }^{31}$ Sánchez remite a (Murray, 1999: 83-101). 
Basándose en la propiedad de almacenamiento de información, los medios digitales son enciclopédicos. Debido a las prestaciones de gestión de la información de los dispositivos, fundamentalmente memorias $\mathrm{RAM}^{32}$, ROM y procesadores (CPU). A partir de la aparición de Internet, además gozan de la posibilidad de conexión entre diferentes dispositivos y con acceso a la "nube" (Cloud) o almacenes de datos que procuran una ingente cantidad de información. La capacidad del hipertexto, como enlaces sucesivos a subsiguientes pantallas o escenarios hacen de la navegación digital una verdadera telaraña de contenidos.

La posibilidad que ofrece este tipo de transmisión de contenidos se utiliza para comunicaciones institucionales o corporativas, cambiando definitivamente las relaciones de emisión y consumo de los mass media. Vemos que el alcance es muy importante y está en desarrollo.

Las nuevas formas de administración electrónica facilitan que los poderes públicos y los periodistas ofrezcan a los ciudadanos/as información pública clara y de calidad, que permita participar, en una primera fase, en la comprensión de algunos de los documentos complejos que se generan. Con las fuentes de gobierno se pueden hoy dia organizar documentos visuales por medio de formas multimediáticas e interactivas de interés semántico, difundidas en las webs municipales, con las que los ciudadanos pueden adquirir conocimientos y desarrollar asi también la democracia participativa. (Valero, 2012: 211).

En este medio en el que los lenguajes se expresan de manera novedosa y en los que estamos en sus inicios, no podemos aventurar como se irá conformando estas narrativas que emergen, pero sí que se observan tendencias: "Se puede entender que [la infografía] es el camino para nuevas formas textuales en las que nos podemos entender todos de una forma más funcional y no necesariamente imprecisa ni superficial." (Valero, 2012: 212).

\footnotetext{
${ }^{32}$ RAM (Random Access Memory), o memoria de trabajo. ROM (Read Only Memory) o memoria de almacenamiento. CPU (Central Processing Unit) es el hardware o máquina donde se interpreta las instrucciones de un programa.
} 


\section{Narrativa multimedia}

Las cuatro características ${ }^{33}$ mencionadas en el apartado anterior sobre los medios digitales promueven las funciones de interactividad (secuencialidad y participación) e inmersión (espacialidad y enciclopedismo). Interactividad e inmersión en el medio dan forma a nuevas posibilidades narrativas. La intervención activa y proactiva del usuario y su compromiso explícito con el relato obligan al autor a plantear un control sobre la historia y permiten al intérprete su modificación.

Es interesante y pertinente observar la evolución de la comunicación. Cloutier divide "la historia de la comunicación en cinco episodios que se corresponden con cinco tipos de medios" (Aparici y García, 2017: 75) 34 :

1- La comunicación interpersonal. Gestos y sonidos hasta establecer el lenguaje. Cada sujeto en la comunicación actúa como emerec.

2- La comunicación de las élites. La aparición de la escritura como sistema de comunicación perdurable y asíncrona permite que su uso privilegie a unas élites que poseen el código.

3- La comunicación de masas. Empieza con la producción tipográfica y su difusión y sigue con la imagen, grabados y fotografía, grabación del sonido y finalmente, audiovisual con movimiento. Producción de un original y reproducción para amplificar el número de mensajes.

4- La comunicación individual. Vinculado a las tecnologías self medias. El receptor escoge el momento de consumo de los contenidos y le permite enviar mensajes escritos y también audiovisuales.

5- La comunicación universal. Aparición del net medias, basados en la interconexión, por ejemplo, Internet (Aparici y García, 2017: 7577)

${ }^{33}$ Recordamos que los entornos digitales, según Murray (1999: 83-101), tienen características: a) secuenciales, b) participativas, c) espaciales y d) enciclopédicas. ${ }^{34}$ Según la cita: Cloutier, Jean (2010). Cap. 2, Historia de la comunicación, Págs. 4550. Cloutier, Jean (1973) La comunication audio-scripto-visuelle á l'heure des selfMedia ou l'ere d'emerec. Montreal: Les Presses de l'Université de Montréal.

Cloutier, Jean (2001) Petit traité de communication. EMEREC à l'heure des Technologies numériques d'information et de communications. Montréal/Gap: Carte blanche/ Atelier Perrousseaux. 
Así pues, el lenguaje oral, la escritura, la imprenta, la tecnología de almacenaje de contenidos e Internet son los cinco hitos en la historia de la comunicación que provocan, a su vez, un cambio social. La tecnología y la comunicación van siempre vinculadas. Las características que ofrece la tecnología se implementan en nuevos modos de comunicación.

El modelo lineal de la narración con planteamiento, nudo y desenlace como paradigma clásico se ha expandido en los medios digitales. "El lenguaje de las nuevas narrativas se fundamenta en los siguientes principios: La hipermedialidad, la convergencia, la digitalización, la modularidad, la automatización, la variabilidad, la propagabilidad y la interactividad" (Aparici y García, 2017: 145-149). Estas características de la narración en el entorno digital son posibles, lógicamente, por el medio. Manovich (2005: 72-95) destaca cinco características de lo que llama nuevos medios: a) representación numérica; b) modularidades; c) automatización; d) variabilidades; e) transcodificación. Hay un paralelismo entre las características de los medios y las narraciones que se producen.

Estos nuevos medios no sólo promueven formas inéditas de narración sino que influyen en las que ya existían: [...] la informatización de la cultura no conduce solamente al surgimiento de nuevas formas culturales, como los videojuegos y los mundos virtuales, sino que redefine la fotografía y el cine que ya existian. (Quiroga, 2016: 289-290).

Estas nuevas formas de comunicación no son sólo derivaciones del lenguaje verbal, sino que "también se pueden ver multitud de lenguajes no verbales y la lógica simbólica está adaptándose a un mundo que tiene prisas por conocer las cosas que le incumben" (Valero, 2012: 211) en sintonía con Català (2001: 17) que advierte que "la palabra ya no parece estar capacitada para dar cuenta de buena parte de la realidad".

Se aprecia una necesidad de comunicación y unos medios en los que la narración adquiere nuevas formas en base a una síntesis de lenguajes ya existentes, pero ahora combinados entre si para formar otras maneras de narrar "que no se circunscriben únicamente a la imagen, ya 
que lo verdaderamente interesante es la síntesis de lenguajes que hacen posible cualquier explicación óptima de la realidad." (Valero, 2012: 211).

\section{Aumento de conocimientos y comprensión lectora}

Uno de los índices que buscamos en la investigación de la efectividad de la infografía respecto a otros lenguajes para transmitir conocimiento es, justamente, el aumento de conocimientos del receptor. Es decir, es la variable dependiente que nos da información sobre la efectividad de la infografía ${ }^{35}$.

Otra variable que actúa en la transferencia de conocimientos es la comprensión lectora. Básicamente, esta comprensión se mide sobre lenguaje verbal escrito.

La OECD ${ }^{36}$, es una organización intergubernamental que promueve el desarrollo económico y permite la comparación de experiencias de las políticas económicas de los diferentes miembros para buscar respuestas a los problemas comunes, así identifican políticas internas y externas exitosas. Uno de los indicadores que mide en sus análisis es la comprensión lectora como factor que incide en la educación y posteriormente en las oportunidades de los ciudadanos en el mercado laboral y su bienestar. A la vista de la Figura 1, observamos una mejora de la comprensión lectora en la generación de 25 a 34 años sobre la de

\footnotetext{
${ }^{35}$ Para más información sobre la investigación: Valero, 2012 y 2014; Morera, 2017 36 The Organisation for Economic Co-operation and Development (OECD). Es una organización creada en 1960 por 18 países europeos más EEUU y Canadá dedicada al desarrollo económico. Actualmente los miembros de la OECD son 35 países. "The mission of the Organisation for Economic Co-operation and Development (OECD) is to promote policies that will improve the economic and social well-being of people around the world. [...] We also look at issues that directly affect everyone's daily life, like how much people pay in taxes and social security, and how much leisure time they can take. We compare how different countries' school systems are readying their young people for modern life, and how different countries' pension systems will look after their citizens in old age [...] The evidence shows that using both cognitive (literacy, numeracy) and "soft" (communicating, influencing, negotiating) skills in the workplace and maintaining them over a lifetime is strongly related to greater skills proficiency - which, in turn, is related to economic and social well-being." En línea http://www.oecd.org/about. Recuperado el 10 de noviembre de 2017.
} 
55 a 65 años y, concretamente en España, una menor puntuación respecto a otros países de su entorno.

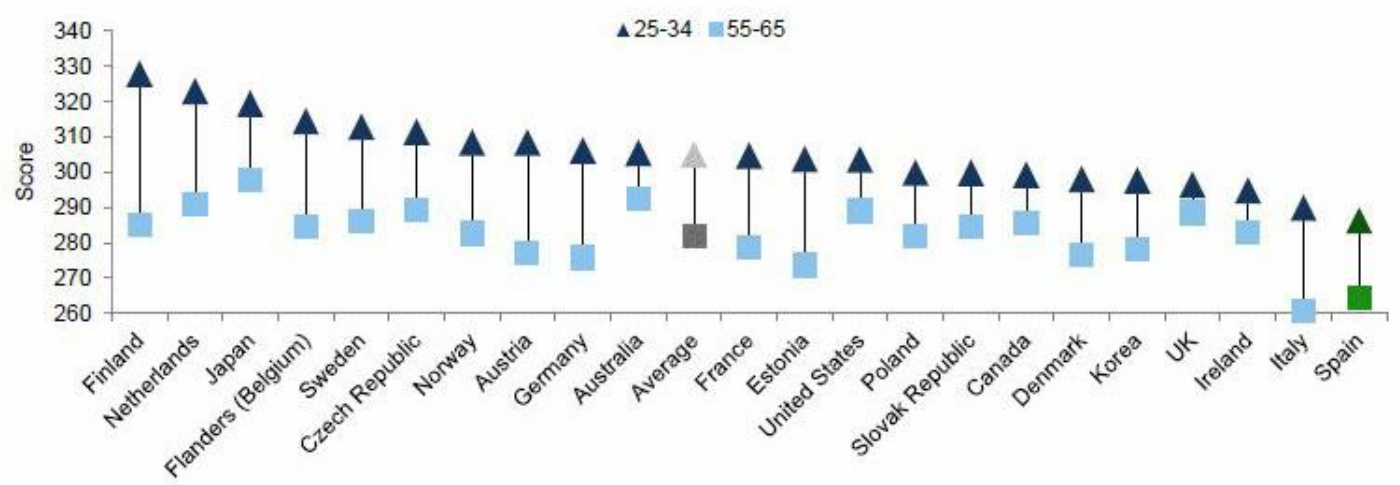

Figura 1. Puntuación media en comprensión lectora de los titulados en estudios terciarios, población de 25 a 34 años y de 55 a 65 años, países seleccionados, PIACC 2012 (examen PISA para adultos).

Fuente: Rafa Galán del Río "Perpe" ${ }^{37}$ sobre datos de la OECD.

Aunque el nivel de alfabetización (literacy) en España es casi total, como vemos en la Figura 2, ello no se corresponde con la comprensión lectora, como hemos visto.

Por tanto, si una comunicación puede mejorar los niveles de comprensión o de aumento de conocimientos de un lector, estaremos ante una oportunidad que no debemos pasar por alto. La infografía, como lenguaje sintético (verbal más icónico) aporta un margen de mejora ante el lenguaje verbal escrito en cuanto al aumento de conocimientos del lector.

37 Gráfico elaborado por el perfil de Twitter @_perpe_ En línea https://twitter.com/ perpe/status/928906579818115072. Recuperado el 10 de noviembre de 2017. "The Survey of Adult Skills (PLAAC) is an international survey conducted in 40 countries that measures the key cognitive and workplace skills needed for individuals to participate in society and for economies to prosper. It measures, in particular: Literacy, Numeracy, Problem solving in technology-rich environments." En línea http://www.oecd.org/skills. Recuperado el 10 de noviembre de 2017. 


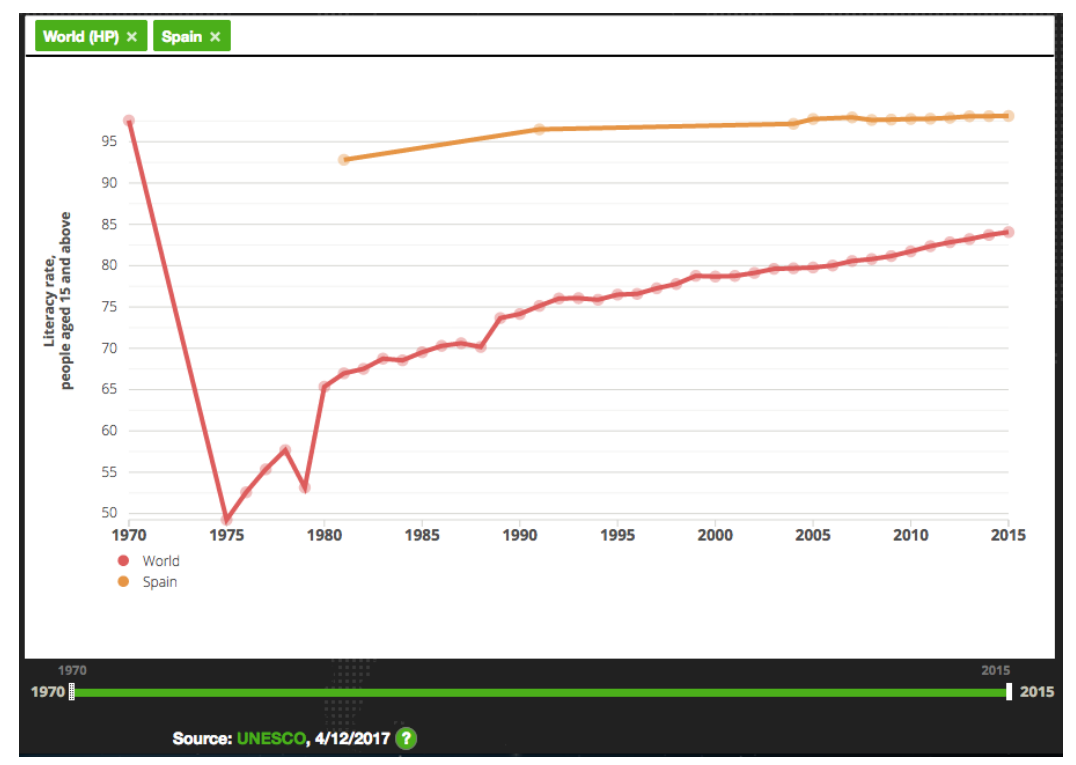

Figura 2. Literacy rate, people aged 15 and above. España y Mundo. Desde 1970 a $2015^{38}$.

Fuente: UNESCO.

Uno de los resultados que se han repetido en la investigación trata de la idoneidad de la infografía respecto a los receptores que a priori saben menos del tema expuesto por el contenido de la misma. "La infografía digital permite a los que saben menos adquirir mayor aprovechamiento." (Valero, 2012: 225 y Valero, 2014: 115). Esta relación pone en evidencia que la infografía es un producto válido para un determinado público que tiene más dificultades en comprensión lectora.

Puede que nos encontremos ante una situación de aprendizaje de la comunicación del futuro, con nuevos textos que permitan suponer que con combinaciones de lenguajes tan eclécticos como los propios de la infografía digital, se acabe por un lado adaptándose óptimamente a los intérpretes y por otro alfabetizándolos con esas nuevas formas simbólicas o figurativas que parece que permitirán en un tiempos relativamente breve, por supuesto inferior al plazo que se dieron en el origen de la imprenta para el desarrollo de matrices, con las que saltar la categoría de productos incunables (cincuenta años posteriores a la invención de la imprenta), hacer entender los conceptos más complejos, con otras presentaciones y puede que otros lenguajes nuevos o novedosos (ver Heller, 2006: 107 y siguientes). (Valero, 2012: 224)

38 En línea http://humanprogress.org/f1/2116/1970/2015/Spain/World. Recuperado el 11 de noviembre de 2017. 


\section{Infografía. Límite y expansión}

Para Jordi Català ${ }^{39}$, La infografía es informar visualmente, comunicar en imágenes. Todo, absolutamente todo, es infografiable, tan sólo hay que ordenar, sintetizar, organizar y traducir la información teniendo en cuenta el destinatario final. Esta aseveración es tanto como considerar la infografía como un lenguaje con el que se puede "narrar" en cualquier registro o, en otras palabras: La infografía digital hace posible o facilita la comprensión de los acontecimientos, acciones o cosas. (Valero, 2008: 497). Esta característica que acerca la infografía a un lenguaje es la propiedad que Morera (2017: 352) denomina recursividad $^{40}$ : La infografía es un lenguaje visual multimedia de carácter ecdótico y con la propiedad de recursión.

Esta consideración de la infografía como lenguaje visual multimedia es -parece obvio- una característica coincidente con los medios digitales y, en concreto, Internet. "La aparición de la palabra en el filme no modificó sustancialmente las posiciones teóricas existentes a su alrededor. [...] Pero todo esto sólo fue un episodio." (Metz, 2002: 77). La palabra en el cine aumentó las posibilidades comunicativas del lenguaje visual y pasó a ser audiovisual. De igual manera que la tecnología permite evolucionar y transformar el lenguaje cinematográfico, así nos encontramos actualmente en Internet, se está formando un lenguaje que nos es conocido por alguna de sus características (ya sea el visual, el verbal, etc.) pero que en su conjunto (lenguaje de síntesis) aporta otra dimensión en la percepción

${ }^{39}$ Sobre la exposición Del cuter a las redes sociales. Jordi Català: comunicación visual y estrategias en la infografía, exposición retrospectiva de la obra de Jordi Català en la biblioteca de la Facultad de Comunicación de la UAB, del 13 de diciembre de 2016 al 24 de febrero de 2017. Comisariada por José Luis Valero Sancho. Nota de prensa en línea: http://www.jordicatalainfographics.com/uploads/3/1/0/4/31044179/nota d e prensa invitaci\%C3\%93n.pdf. Recuperado el 10 de noviembre de 2017.

${ }^{40}$ DRAE: Recursivo: 3. adj. Gram. Dicho de una unidad o una estructura: Que puede contener como constituyente otra del mismo tipo. En línea: http://dle.rae.es/?id=VXkDTwd. Recuperado el 10 de noviembre de 2017. Esta propiedad de cariz fractal es la que permite explicar pensamientos incluidos dentro de otros pensamientos. Chomsky sostiene que el pensamiento humano se ha generado por una combinación aplicada de forma recursiva. 
por parte del usuario y las sucesivas transformaciones sociales como relación entre usuarios.

Para un cine que se declaraba lenguaje, pero se pensaba como lengua [...] no se podía pensar seriamente en integrarlas [las lenguas] en el juego de las imágenes, aún menos en fusionarlas con éste, apenas en conciliarlas. [...] El cine sólo se hizo hablado cuando se concibió como un lenguaje flexible, nunca fijado de antemano [...]. (Metz, 2002: 80)

Deberemos esperar a que, como ocurrió con el cine, la flexibilidad de los distintos lenguajes que concurren en la comunicación por Internet acaben por formar un lenguaje propio, de síntesis; y, como ocurre con el lenguaje cinematográfico, irá evolucionando con el uso.

La nueva tecnología está aportando unos nuevos textos con los que la sociedad se está alfabetizando y adaptando que, al igual que pasó con los mapas del tiempo, comprenderá fácilmente y serán de dominio público por su presentación morfológica y conceptual. Cada vez hay más propuestas complejas pero muy efectivas elaboradas con formas y navegaciones simples en el ámbito de internet. (Valero, 2014: 117).

\section{Adecuación de la infografía a las nuevas narrativas}

Compararemos las características de los medios digitales, sus narrativas con las características de la infografía para ver si hay coincidencia entre ellas y nos permite hablar de adecuación de la infografía al medio como producto narrativo. Para ello atendemos a las características de lenguaje en el entorno digital, estructura narrativa y el contrato de lectura en el sentido de propuesta visual semiótica.

El modelo de lenguaje de los relatos digitales define unas características de las nuevas narrativas (Aparici y García, 2017: 145-149). Veamos: Hipermedialidad, Convergencia tecnológica y comunicativa, Digitalización, Modularidad, Automatización, Variabilidad, Propagabilidad e Interactividad. 
Para Metz (2002: 43-53), en su acercamiento a la fenomenología de lo narrativo desde una posición estructuralista, un relato (cinematográfico) se reconoce por cinco características:

1 - Un relato tiene un principio y un final.

2 - Un relato es una secuencia temporal. Una sucesión más o menos cronológica de acontecimientos.

3 - Todo relato es un discurso. Remite forzosamente a un sujeto de la enunciación.

4 - El relato irrealiza la cosa-contada. La realidad supone la presencia.

5 - El relato constituye una sucesión de acontecimientos.

Para acceder a la dimensión pragmática de la narración y la consecuente recepción por parte del intérprete entendemos que se produce un vínculo que se asemeja a un código entre partes, un contrato, a decir de Verón (1985: 12): "La relación entre un soporte y su lectura reposa sobre lo que llamaremos el contrato de lectura. El discurso del soporte por una parte, y sus lectores, por la otra. [...] En el caso de las comunicaciones de masa, es el medio el que propone el contrato". ${ }^{41}$

Para el análisis de un determinado soporte comunicacional y con el fin de localizar su contrato de lectura, propone tres puntos:

1 - la regularidad de las propiedades descriptas.

2 - la diferenciación obtenida por la comparación entre los soportes.

3 - la sistematicidad de las propiedades exhibidas por cada soporte.

(Verón, 1985: 6).

Una vez analizado el soporte, "[...] se estudian las actitudes y las reacciones de los lectores y no-lectores en vistas a objetos de los cuales no se conocen sus propiedades precisamente en cuanto objetos de lectura." (Verón, 1985: 12)

El éxito de un soporte de la prensa escrita se mide por su capacidad de: a) proponer un contrato que se articule correctamente a las expectativas,

\footnotetext{
41 "El contrato enunciativo es una dimensión fundamental del funcionamiento de no importa cual sea la media dentro de las comunicaciones de masa, y aquel que sea el soporte significante (radio, televisión, etc.). Nuestra demarcación es para la media en general." (Verón, 1985: 12).
} 
motivaciones, intereses y a los contenidos del imaginario de lo decible visual. b) de hacer evolucionar su contrato de lectura de modo de "seguir" la evolución socio-cultural de los lectores preservando el nexo. c) de modificar su contrato de lectura si la situación lo exige, haciéndolo de una manera coherente. (Verón, 1985: 2).

El contrato exitoso propuesto por el soporte es un contrato pertinente, progresivo y adaptable. Es decir, está dispuesto hacia el éxito comunicativo con su audiencia.

Todas las características que hemos apuntado, ya sea de lenguaje (código), narración (producto) o soporte (medio), se adecúan a la infografía como producto multimedia pero también como lenguaje visual multimedia.

\section{La infografía como lenguaje visual}

Hemos definido a la infografía como un producto de comunicación multimedia. Síntesis de lenguajes en una propuesta que actúa como sistema. (Morera, 2017: 483). Sin embargo, también hemos apuntado que la infografía puede actuar como lenguaje (síntesis de lenguajes) que adquiere formas que se adaptan al medio digital en el que convive ventajosamente puesto que se adapta por su idoneidad multimedia. En este sentido hay un precedente en el lenguaje audiovisual en el que los [códigos] que han sido considerados como propios de los medios audiovisuales no son especificos, varian constantemente y no son susceptibles de atenerse a reglas según un repertorio léxico finito. (Sánchez, 2006: 82).

En la comunicación humana, un acto tan simple como un dedo extendido es capaz de transmitir informaciones muy complejas. Tomasello (2013: 84-85) pone de manifiesto la infraestructura psicológica del gesto icónico natural y su capacidad de comunicación que, a menudo, se atribuyen al lenguaje verbal.

Uno de los vectores por los que se reconoce la conectividad en Internet es su capacidad de establecer cooperaciones entre nodos. Tomasello (2013: 82) propone tres etapas en el proceso de la "infraestructura psicológica implicita en la comunicación cooperativa bumana -natural o 
convencional - que entrañan una intencionalidad compartida". Habla de esta "intencionalidad compartida" y el modelo que propone es el de "modelo cooperativo de comunicación humana" con cinco características:

- Intención comunicativa conjunta que tiende a una comunicación eficaz.

- Atención y comprensión conjunta de la situación.

- Móviles prosociales de la comunicación. Ayuda y colaboración sin esperar retorno.

- En toda circunstancia comunicativa los participantes suponen una colaboración mutua.

- Las normas comunicativas compartidas son aceptadas como convención por los participantes.

Lenguaje y colaboración como actitudes sociales. Códigos compartidos antes de estructurar un lenguaje. Sensación y voluntad de colaboración en objetivos prosociales. Estas características del lenguaje gestual o icónico en relación a lo verbal oral son características que también se apuntan en la infografía como elemento estructurado en base a un lenguaje verbal escrito y la aparición de elementos icónicos cuyo objetivo es aportar información para una comunicación más eficaz.

\section{Lenguaje de síntesis, síntesis de lenguajes}

'La infografía como sintesis de lenguajes es un producto de semiosis, puesto que actúa con signos y produce significados.' (Morera, 2017: 485). De hecho, la síntesis resultante es un nuevo lenguaje que permite nuevas narrativas que combinan aspectos de distintos lenguajes. Desde el lenguaje verbal (oral y escrito) al icónico, con incorporación de movimiento, secuencialidad e interactividad.

Sólo las culturas alfabéticas han llegado a dominar la secuencia lineal conexa como formas generalizadas de organización social y psíquica. [...] La civilización se ha erigido sobre la capacidad de leer y escribir porque la alfabetización supone un tratamiento uniforme de una cultura con el sentido de la vista, extendido en el espacio y el tiempo por el alfabeto. (McLuhan, 2005: 103). 
La narración es un vehículo idóneo para compartir información y conformar al grupo. Las narraciones evolucionan en el tiempo creando convenciones a partir del contexto lingüístico aceptado. La narración atiende aspectos de espacio, tiempo y protagonistas para estructurar un producto acorde con la historia - en el sentido de cultura, no de relato- pero útil y efectivo en el contexto social en el que incide. Para Tomasello (2013: 207), estas narraciones son discursos complejos cuya construcción requiere identificación, estructuración y expresión.

Consideramos la infografía como un sistema de relaciones entre lenguajes que presentan un resultado final particular. "[...] las propiedades gestálticas de las construcciones pueden incluso "predominar" sobre el significado individual de las palabras." (Tomasello, 2013: 215) ${ }^{42}$. En igual sentido, la infografía aporta un mayor conocimiento por su disposición, por la experiencia que tenemos en leer anteriores ejemplos en los que accedemos a la información concreta y extrapolamos esta comprensión a sucesivas lecturas del mismo patrón visual.

Por todo ello, la evolución que nos ha llevado al lenguaje verbal como máxima expresión de la comunicación cooperativa parece que estamos en el avance de un paso evolutivo en el lenguaje visual en el que la infografía tiene un doble protagonismo: como producto específico que se adapta y es consecuencia de la tecnología y también como lenguaje propio de los medios digitales como síntesis de lenguajes.

También el lenguaje cinematográfico ha ido construyendo su estatuto, su contrato con respecto al público. Pasar de la imagen fija a la imagen en movimiento supuso un cambio de narración al que se tuvo que acostumbrar el público. Surgen nuevas sintaxis, nuevas semánticas que permiten nuevas comunicaciones. "Sólo el montaje permite trascender la fotografia en cine, el calco en arte. Definido en sentido amplio, se confunde

\footnotetext{
${ }^{42}$ Para ilustrar la cita, Tomasello pone de ejemplo lingüístico la expresión "El grexor fue mibeado por el dit", en la que el receptor sabe - aunque no sepa el significado de las palabras — que "el dit hizo algo (que llamamos mibear) al grexor (y que he descrito ese evento desde la perspectiva del grexor, el paciente)."
} 
simplemente con la composición misma de la obra." (Metz, 2002: 58) ${ }^{43}$. Eisenstein ya recurre a la literatura y la pintura para encontrar "ejemplos de montaje avant la lettre." (Metz, 2002: 59). Todo es montaje, llega a decir Eisenstein. De la misma manera, ahora le toca el turno al lenguaje multimedia interactivo. Nuevas maneras de narrar y búsqueda de formas sintácticas y semánticas en el entorno digital.

\section{Confluencia de lenguajes. Lenguaje audiovisual y lenguaje visual}

La infografía como producto de comunicación es un enunciado visual multimedia (De Pablos, 1999: 19; Valero, 2012b: 91; Morera, 2017: 270). Ahora bien, hay espacio para considerar el texto (verbal escrito) como lenguaje visual puesto que por el canal visual se percibe el carácter denotativo de la estructura tipográfica pero también el carácter connotativo de la disposición de la misma. Esto lleva a la consideración de advertir una "confluencia entre texto e imagen como evolución al lenguaje verbal escrito." (Morera, 2017: 485). Una prueba de esta evolución es el uso de emoticonos en el lenguaje de las redes sociales por Internet. La confluencia de lenguajes enriquecerá por extensión el lenguaje escrito. Aspectos de la infografía como lenguaje reforzarán el lenguaje escrito gracias a la posibilidad de la tecnología y la conectividad en torno a Internet.

En un mundo globalizado y conectado ${ }^{44}$ por Internet, con lenguas de uso y culturas diversas "[las] convenciones "arbitrarias" [en el acto comunicativo] son posibles sólo si todos los individuos tienen aptitudes relativamente importantes para hacer algún tipo de aprendizaje cultural de carácter imitativo centrado en las acciones intencionales." (Tomasello, 2013: 81). El uso y la confluencia de las propuestas comunicativas parece lógico que

${ }^{43}$ Recoge una declaración de Pudovkin en Cinéa-Ciné pour tous, 1 de enero de 124. Reeditado en la recopilación de Pierre Lherminier, L'art du cinéma, Seghers, 1960, págs. 189-200.

${ }^{44}$ En este punto no podemos olvidar la 'brecha digital' que impide la llegada a la información en condiciones a buena parte de usuarios, ya sea por cuestiones técnicas, políticas o de pobreza. Cuando decimos 'globalizado' hay que acotar el término y no por cuestiones puramente geográficas. Para ampliar información en línea: https://www.digitaldivide.org/dd-redefined Recuperado el 10 de noviembre de 2017. 
deban ir acercándose entre ellas a fin de buscar modos comunes de comprensión. La infografía como producto multimedia visual, pero también en evolución en cuanto formato, estará en óptimas condiciones para ofrecer soluciones de comunicación vía Internet.

El formato de la infografía en el entorno digital actúa como pieza acabada de comunicación en su formato fijo. En formatos complejos propone una interactividad que le permite estructurarse en nodos vinculables mediante acciones voluntarias del usuario. La infografía como pieza única simple o como narración extendida cumple con la afirmación que "el relato interactivo será aquel relato que estructure la información en lexias conectadas a través de enlaces que propongan opciones de lectura y requiera la participación del usuario." (Rausell, 2005: 3).

El relato audiovisual interactivo sería un tipo de discurso audiovisual interactivo que, en tanto relato, aludiría a un tipo de discurso que narra una bistoria y que, en tanto audiovisual, incorporaría al menos fragmentos de imagen en movimiento (cinemimética o cineinfográfica) con sonido. Asimismo, en tanto interactivo, incorporaría la posibilidad de intervención del espectador en la historia de formas muy diversas. Así, podría participar como lecto-autor, taly como lo denomina Moreno ${ }^{45}$, o podría participar como personaje:principal o secundario, en tercera persona mediante un avatar o en primera por inmersión (concepto que tomamos de Murray). (Rausell, 2005: 7)

Como apreciamos en el texto anterior, no sólo son intercambiables los conceptos de 'relato visual interactivo' con el de 'infografía' sino que aparece también otro concepto, el de 'cineinfografía' que hace explícita la presencia de la infografía en el relato audiovisual interactivo. En este contexto, sería correcto también decir 'el lenguaje infográfico' aplicado a una pieza cinematográfica. En este punto llegamos a los límites de la terminología y constatamos, una vez más, los problemas de una taxonomía que delimite fronteras en la infografía.

Nuestra propuesta de considerar la infografía como producto de comunicación, pero también como lenguaje puede ayudar a resolver esta ardua cuestión. No necesariamente todo producto en el que

${ }^{45}$ En el texto, remite a: [Moreno, I.: Musas y nuevas tecnologías. El relato hipermedia, Paidós, Barcelona, 2002]. 
aparezcan características infográficas sea una infografía, sino más bien, que el lenguaje infográfico se desenvuelve en otros productos de comunicación dándoles las características de infografía. Recordemos que, por naturaleza, la infografía es multimedia.

\section{Características de la infografía en el medio digital}

Marín (2009: 212) apunta tres obstáculos en la normal implementación de la infografía en el medio digital periodístico. Producción, distribución y recepción son los tres ámbitos en los que se producen los obstáculos. 1) La infografía es un trabajo complejo y para su producción necesita de colaboraciones entre redactores, periodistas e infógrafos. Aunque las funciones se puedan solapar, sí que se debe construir la infografía atendiendo los criterios desde estas perspectivas. 2) En cuanto a la distribución, el avance de los recursos tecnológicos no debe hacer olvidar que no siempre y en todo lugar hay un acceso a Internet en condiciones. 3) Las nuevas generaciones de usuarios tienen unos hábitos distintos de acceso a la información. Los nativos digitales gozan de unos canales de mayor calidad y con mayor velocidad en la transmisión de contenidos.

Colaboración en la producción, tecnología de distribución y nuevos hábitos de lectura de la audiencia son las tres características que se deben tener en cuenta de los nuevos formatos de información mediante infografía en el medio digital.

Cuando el canal de transmisión permite y favorece la confluencia de medios, la presentación de contenidos es en formato multimedia. Imágenes, texto, sonido, movimiento e interacción permiten aumentar la potencialidad del mensaje; así, no sólo activamos más de un sentido del receptor o usuario, sino que el producto final recibido, entendido como un todo, aporta unas características específicas.

La narrativa multimedia es un mensaje, una historia, difundida en múltiples medios. O también, una historia compuesta de múltiples medios presentada en una plataforma que permite su difusión. Las diferencias entre narrativa lineal y narrativa multimedia permiten a esta última ser interactiva gracias al medio. 


\begin{tabular}{|l|l|l|}
\hline & Narrativa lineal & Narrativa interactiva \\
\hline Contenido & Cerrado & Abierto \\
\hline Forma & Estática & Variable \\
\hline Acto & Narrador & Usuario \\
\hline
\end{tabular}

Figura 3. Características entre narrativa lineal e interactiva.

Fuente: Orihuela, 1997: 39.

En narrativa interactiva aparecen conceptos nuevos de distribución en los que el usuario actúa -interactúa- de tres maneras distintas: multiplataforma, crossmedia y transmedia ${ }^{46}$.

El relato multiplataforma parte de un relato que es contado en diferentes soportes o medios. La historia se adapta al medio. La narrativa crossmedia discurre entre distintos medios. La historia debe completarse en diferentes plataformas que unen los fragmentos ya experimentados. La narrativa transmedia son múltiples historias difundidas por múltiples medios que juntas conforman una gran historia de manera más ubicua.

El esquema de funcionamiento a lo largo del tiempo de consumo de la narrativa tiene las formas que vemos en las siguientes figuras en las que hemos añadido el producto "infografía".

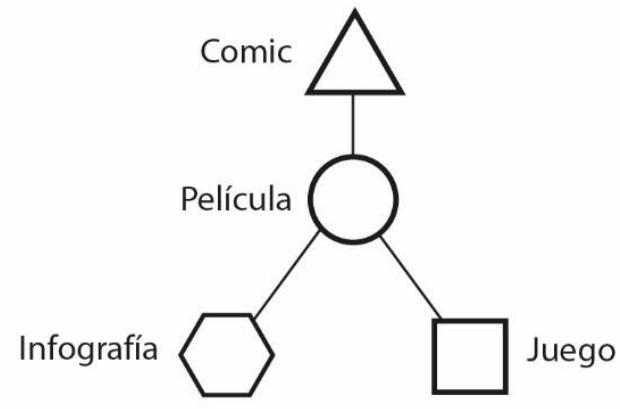

Tiempo

Figura 4. Producto Multiplataforma. Basado en Costa y Piñeiro, 2012: 110. Fuente: Elaboración propia.

${ }_{46}$ Terminología y concepto planteado por Jenkins en 2006. 


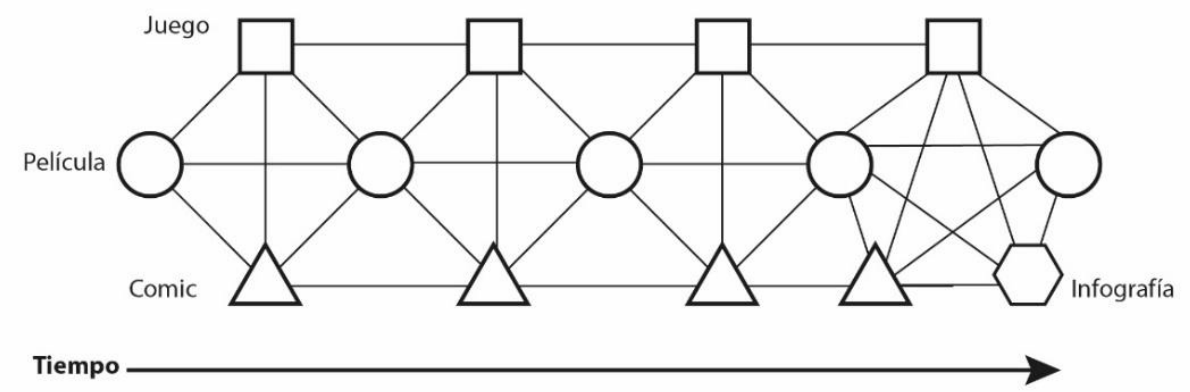

Figura 5. Producto Crossmedia. Basado en Long, 2007: 18.

Fuente: Elaboración propia.

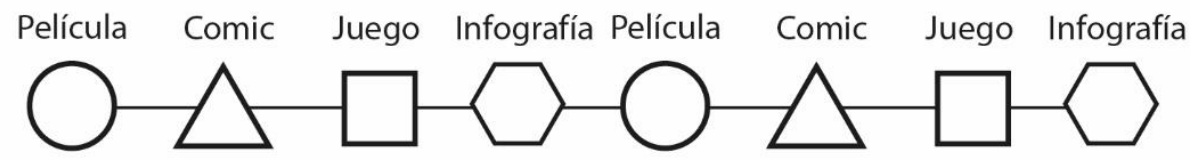

Tiempo

Figura 6. Narrativa Transmedia. Basado en Costa y Piñeiro, 2012:113 y en Long, 2007: 15.

Fuente: Elaboración propia.

En las figuras anteriores (4, 5 y 6 ), en las que se explican los tres conceptos -multiplataforma, crossmedia y transmedia- hemos incorporado la infografía como producto de comunicación además de los ya existentes como ejemplo: película, cómic y juego. La infografía aquí tiene igual consideración comunicativa que los demás productos por los que se difunde la historia, o una parte de ella, según el gráfico. La categoría de la infografía como elemento autónomo y cerrado que narra una historia concreta o parte de ella. En este sentido, su uso comunicativo es similar al que pretenden los otros productos media: una película, un cómic o un juego. Cada formato tiene unas características propias y se distribuye y se consume de manera distinta por la audiencia.

Scolari (2013) describe a las narrativas transmedia, como cross-media, plataformas múltiples (multiple platforms), multimodalidad (multimodality), narrativa aumentada (enhanced storytelling) $o$ mundos transmedia (transmedia worlds). [...] Cada medio cuenta la historia con total autonomia e independencia narrativa, y las interconexiones 
sucesivas hacen que el relato se expanda y los contenidos converjan a través de esos medios. (Quiroga, 2016: 290).

No es extraño que aparezcan nuevos conceptos que describan nuevas distribuciones de contenidos o nuevos consumos de ellos. Por una parte, la tecnología abre nuevos caminos y por la otra, el consumidor, ávido de relatos, reclama más oportunidades de conseguirlos. Se crea un compromiso entre ambos.

Así, pues, en lo expuesto anteriormente, la infografía actúa como unidad de comunicación, como producto elemental vinculado a las demás piezas de comunicación, puesto que explica la misma historia o parte de ella. No encontramos diferencia cualitativa entre la carga de narración de un cómic o una película a la que nos ofrece una infografía. No comparamos su alcance o su bondad, sino su propósito comunicativo. Cada producto tiene su público objetivo y, por supuesto, tiene unas capacidades comunicativas propias y características.

\section{Conclusiones}

La infografía es un producto de comunicación y un lenguaje multimedia que se adapta a las nuevas narrativas en el entorno digital.

Toda narrativa multimedia no es una infografía, pero sí que la infografía puede aparecer en cualquier narrativa multimedia. Y abundando, se pueden hacer relatos de manera infográfica ya que es un lenguaje multimedia que se adapta muy bien a las plataformas de difusión digitales.

Las características de los nuevos medios también son propias de la infografía. En base a la interactividad y la inmersión en estas nuevas narrativas, las otras características destacadas que también cumplen los relatos infográficos son:

\section{Medios}

Representación numérica, Modularidad, Automatización, Variabilidad y Transcodificación. 


\section{Narraciones}

Hipermedialidad, Convergencia, Digitalización, Modularidad, Automatización, Variabilidad, Propagabilidad e Interactividad.

\section{Infografía}

Representación numérica, obviamente es digital en su naturaleza, pero también por su representación de números en modo gráfico y visual; Modularidad, por cuanto se produce en nodos y enlaces de hipertexto y una infografía contiene infogramas o módulos incorporados amén de otros elementos significativos discretos; Automatización, en referencia, por ejemplo, a la visualización automática de los datos asociados a modelos de representación; Variabilidad, como presentación fractal de los contenidos y a su lectura en escala de desarrollo secuencial; Transcodificación, o adaptación de los códigos inherentes a los distintos formatos. La misma presentación responsive ${ }^{47}$ de los contenidos ya es una muestra de transcodificación; Hipermedialidad, la suma de hipertexto y multimedia. La infografía es multimedia e interactiva, luego hipermedia; Convergencia, en un medio como Internet donde convergen muchos medios, la infografía despliega su potencial comunicativo explotando sus características multimedia; Digitalización, la digitalización inherente al medio permite a la infografía la correcta difusión en Internet y la comodidad de recepción de los distintos medios audiovisuales que contenga; Propagabilidad, la infografía es un gran producto de difusión de contenido por su viralidad debido a lo atractivo de su propuesta; finalmente: Interactividad, como característica propia del formato infográfico que permite una alta participación del usuario.

\footnotetext{
47 Utilizamos la expresión en inglés responsive, a falta de una traducción al castellano que exprese la misma característica de adaptación de la interficie de usuario a los diferentes formatos de visualización en los distintos dispositivos. Se consigue con los módulos media queries de CSS3. Fundéu recomienda traducir responsive por 'adaptativo'. En línea: http://www.fundeu.es/recomendacion/diseno-web-adaptativo-traduccion-deresponsive-web-design-1573/. Recuperado el 10 de noviembre de 2017.
} 


\section{Referencias}

Aristóteles. (2005). Poética. Madrid: Alianza

Català, J. M. (2001). Presentación. Anàlisi, Quaderns de comunicació i cultura, (27) 17-32. Bellaterra (España): Universidad Autónoma de Barcelona

De Pablos, J. M. (1999). Infoperiodismo. El periodista como creador de infografía. Madrid: Síntesis.

Heller, S. (2006). Nigel Holmes, Perfiles de la comunicación gráfica. Nueva York: Jorge Pinto Books

Jenkins, H. (2006). Convergence Culture: Where Old and New Media Collide. Nueva York: New York University Press.

Long, G. A. (2007). Transmedia Storytelling. Bussines, aesthetics and prodyuction at the Jim Henson Company. Trabajo final del máster en Science in comparative media Studies presentado en Massachusetts Institute of Techonology. En línea: http://cms.mit.edu/research/theses/GeoffreyLong2007.pdf. Recuperado el 10 de noviembre de 2017.

Manovich, L. (2005). El lenguaje de los nuevos medios de comunicación. Barcelona: Paidós

Marín Ochoa, B. E. (2009). La infografia digital, una nueva forma de comunicación. Tesis doctoral. Universidad Autónoma de Barcelona. En línea: www.tdx.cat/bitstream/handle/10803/48653/bemo1de1.pdf. Recuperado el 15 de agosto de 2016.

McLuhan, M. (2005). Comprender los medios de comunicación. Las extensiones del ser humano. Barcelona: Paidós

Moreno, I. (2002). Musas y nuevas tecnologías. El relato hipermedia. Barcelona; Paidós

Morera Vidal, F. (2017). Aproximación a la infografía como comunicación efectiva. (Tesis doctoral). Universidad Autónoma de Barcelona. En línea, http://hdl.handle.net/10803/457366. Recuperado el 27 de noviembre de 2017.

Murray, J. H. (1999). Hamlet en la holocubierta. El futuro de la narrativa en el ciberespacio. Barcelona: Paidós

Orihuela, J. L. (1997). Narraciones interactivas: el futuro no lineal de los relatos en la era digital. Revista Palabra Clave. 2, 37-47. En línea: http://palabraclave.unisabana.edu.co/index.php/palabraclave/article $\angle$ viewFile/338/480. Recuperado el 10 de noviembre de 2017. 
Quiroga, S.R. (2016). Nuevas narrativas y transmedia: la actividad de las audiencias. Questión. Revista Especializada en periodismo y Comunicación. 1(51): 284-301). DOI: https://doi.org/10.2415/16696581.

Recuperado el 10 de octubre de 2017

Rausell, C. (2005). Nuevos relatos audiovisuales. Hacia una definición del relato audiovisual interactivo. Telos. (62). En línea: https://telos.fundaciontelefonica.com/telos/articulocuaderno.asp@i darticulo $=4 \& \mathrm{rev}=62 \mathrm{htm}$. Recuperado en 10 de octubre de 2017.

Sánchez Navarro, J. (2006). Narrativa audiovisual. Barcelona: Universitat Oberta de Catalunya

Scolari, C. (2013). Narrativas Transmedia. Cuando todos los medios cuentan. Barcelona: Deusto

Tomasello, M. (2013). Los origenes de la comunicación bumana. Buenos Aires: Katz

Valero Sancho, J. L. (2008). La infografía digital en el ciberperiodismo. Revista Latina de Comunicación Social (63): 492-504. La Laguna (España): Universidad de La Laguna. En línea DOI: 10.4185/RLCS-63-2008799-492-504. Recuperado el 10 de noviembre de 2017.

Valero, J. L. (2012). La síntesis infodigital: El cambio en la comunicación local. Zer. Revista de estudios de comunicación. 17(33): 209226. En línea: http://www.ehu.eus/ojs/index.php/Zer/article/view/10631/9869. Recuperado el 30 de diciembre de 2016.

Valero, J. L. (2012b). Infografía digital. La visualización sintética. Barcelona: Bosch

Valero, J. L. (2014). La visualización de datos. Ámbitos: Revista internacional de comunicación. (25): 105-119. En línea, https://dialnet.unirioja.es/servlet/articulo? codigo $=4774691$. Recuperado el 30 de diciembre de 2016.

Verón, E. (1985). El análisis del "contrato de lectura". Un nuevo método para los estudios del posicionamiento de los soportes de los media. Les Médias: Expériences, recherches actuelles, aplications, IREP, París. En línea

http://www.catedras.fsoc.uba.ar/delcoto/textos/veron eliseo analis is del contrato de lectura.pdf. Recuperado el 10 de noviembre de 2017. 


\title{
紫 \\ Infografía: cambio de escenario
}

\author{
Jordi Català Domínguez (G). Departamento de Comunicación \\ Audiovisual y Publicidad. UAB, España. \\ jordicatalad@gmail.com
}

\section{Mi percepción: un prólogo con epílogo}

$\mathrm{D}$ ESPUÉS de tres largos y cambiantes decenios de supervivencia intensa, pero apasionada, centrada en mi principal cometido laboral dentro de la profesión periodística: la infografía, poseemos la suficiente información como para poder afirmar que esta disciplina, actividad y herramienta de comunicación, una vez convertida por méritos propios en género periodístico, se está transformando con fuerzas renovadas, mientras fluye fuera de las redacciones, en una de las mayores herramientas de comunicación visual del siglo XXI.

Los que tuvimos el privilegio de asistir en primera persona, como protagonistas y como cómplices también, a un silencioso parto, un accidentado crecimiento, un engorde exitoso, un desarrollo lleno de respeto y admiración, una edad de oro de esfuerzos sobreseídos y una madurez enriquecida con tecnologías poderosas; somos conscientes de vivir actualmente la sorprendente reproducción de la infografía, similar a un parto múltiple. Los escenarios que se están dibujando con rotunda claridad desde hace más de cuatro años, como enseña cada día esa fuente de observación inapelable llamada Internet, abonan la certeza absoluta de una transformación enormemente desequilibrada: mientras que la infografía languidece en la prensa-papel (no hay inversiones, no 
se crean departamentos, aparecen muy pocos profesionales nuevos) y seguramente correrá la misma suerte que aquella, se está multiplicando con brío, como numerosos síntomas lo demuestran, en cada vez más espacios que la reconocen y la demandan.

\section{Y... ¿qué es infografía para un infografista? 2.1. Puestos a definir}

Cuando los alumnos, tanto los que estudian periodismo como los que se preparan para ser diseñadores, preguntan qué es Infografía, huyendo de definiciones al uso y procurando sintetizar al máximo les respondo que: Infografía es informar visualmente; a mí así me lo ha parecido siempre y así se lo explico a ellos; y si me piden más concreción añado: Infografía es un conjunto de actividades multidisciplinares que, a partir de la reflexión y del análisis, convierten explícitamente cualquier información en imágenes; y además sostengo que infografía, en definitiva es: sintetizar visualmente, comunicar con las imágenes, con ayuda de textos, fotos y recursos que ya son propios de la infografía, tanto estáticos como dinámicos $\mathrm{y} / \mathrm{o}$, multimedia. Y por supuesto, al definirla no hay que olvidar que la infografía se ha convertido en estos años en un excelente género periodístico y, a su vez, un recurso ágil que permite la traducción en imágenes de todo tipo de información, y si además hay un esfuerzo estético detrás, pues mucho mejor.

\subsection{Y, además}

El sustantivo infografía, a nivel de interpretación semántica en su origen anglosajón, pero también latino, no presenta grandes problemas de comprensión: informar-gráficamente, comunicar visualmente, pero, por otro lado, es un término que no abunda en los diccionarios, al menos en su acepción más conocida. En cualquier caso, fruto de años de práctica en el entorno periodístico, la experiencia demuestra que realizar una infografía es también un procedimiento de trabajo que ha de partir siempre de la reflexión y del análisis detallado de cualquier tipo de información inicial (oral, escrita, gráfica, etc.) pero donde también es fundamental tener la certeza de que ésta sea siempre contrastada, lo que obliga a incluir la fuente o fuentes de información, cuando no es el mismo autor de la infografía quien realiza las debidas 
comprobaciones. Para todo ello hay que seguir un proceso en el que inicialmente se fusionan reflexión y análisis de los materiales con los que partimos para entender bien lo que se pretende transmitir y cómo se debe de hacer. El método posterior no es otro que seguir recabando datos, e investigar y añadir materiales paralelos, con los que estructurar, seleccionar, ordenar y jerarquizar la información convirtiéndola en sintética, visual, inmediata, ágil, directa y atractiva y siempre bajo los parámetros de comprensión del usuario al cual se dirige, sin perder de vista nunca la ética periodística. Es muy importante una vez realizada una infografía someterla a un exhaustivo proceso de revisión que implica también una completa edición literaria y de materiales visuales utilizados, con el fin de evitar los errores.

\section{Hablando de profesionales}

El tiempo en que la utilización de gráficos era un servicio más de apoyo a una noticia, o un simple complemento de relleno ya está felizmente superado. Hoy en día un infografista realiza un trabajo periodístico de consideración ya que su producto goza de vida informativa propia, puede acompañar a una noticia, pero también puede ser un complemento integral que permite al redactor del tema compartido, ocuparse de otros aspectos del mismo mientras que la infografía incide en los que el redactor no desarrolla. Los infógrafos, o infografistas (tampoco hay unanimidad de si su producción se trata de infografías o infográficos) ya son periodistas (incluso titulados o con permisos homologados) en tanto en cuanto también trabajan con los conceptos universales de la información: ¿de quién?, ¿qué?, ¿cómo?, ¿cuánto?, ¿cuándo?, ¿dónde? y ¿por qué?, tomados en el orden que más le plazca al lector y realizan cometidos paralelos de investigación, selección, ordenación, jerarquización, diseño, edición, etc. y en definitiva lo que centra este proyecto, desarrollan la narración de un relato visual en forma de síntesis. Un infografista explica, narra, relata, comunica, informa, enseña, sugiere... y todo ello utilizando como instrumento de aplicación unas imágenes que se transmiten con una velocidad espectacular al cerebro humano a través de la vista y con una ventaja apabullante en cifras sobre el resto de los sentidos a la hora de actuar como transmisores de cualquier información externa a las personas. 


\section{Pero, ¿Cuál es el origen de esta historia?}

\subsection{En el principio de la comunicación}

La infografía aparece en el momento en que el ser humano necesita imperiosamente explicar cosas, relatar, comunicarse con los demás, y en ese momento ni existen, o no conoce, o no le sirven, o no le son suficientes, ni las palabras ni la escritura. A lo largo de la historia explicar y explicarse con imágenes, lo que hoy definiríamos como informar visualmente, se ha desarrollado de múltiples maneras, sirvan de ejemplo: las pinturas rupestres, los ideogramas orientales de los que surgen lenguas modernas como las diferentes variantes de chino y el japonés, los jeroglíficos de los imperios Alto y Medio de Egipto, las "scriptoriae" monásticas medievales, los códigos pictóricos del románico, los inquietos tratadistas del renacimiento, entre los que destacó el gigante de Da Vinci, en un evolucionar en la historia de la visualización con la utilización de técnicas cada vez más depuradas. Y así a través de los siglos cada cultura tiene su forma específica de explicar contenidos a partir del hecho visual, siendo las culturas occidentales de Europa y América, más desarrolladas tecnológicamente, las que marcan el ritmo, como referencian estas figuras de diferentes extracciones que, a mediados del siglo XIX, practicaban sistemáticamente la infografía (sin ser conscientes de ello), como instrumento para deducir, para analizar, para explicar, para justificar o para convencer. Figuras míticas que los docentes de lo infográfico siempre tenemos en nuestros labios cuando pretendemos que los alumnos se persuadan, sin fisuras y de entrada, de la utilidad multiplicadora de las narraciones visuales, y sin necesidad de aportar más argumentos, me refiero, cómo no, a los nombres legendarios de Florence Nightingale, el Dr. John Snow o Charles Joseph Minard, entre muchos otros que aún están a la espera de surgir del anonimato.

\subsection{Desarrollo sin retorno}

Pero no ha sido hasta el siglo XX en que la Infografía, en mayúsculas, ha adquirido una entidad compleja propia, irrumpiendo con fuerza a finales de los años ochenta para consolidarse en los noventa y llegar a convertirse ya en el siglo XXI en parte asentada e indiscutible de 
cualquier tipo de medio informativo. Con la aceptación de la Infografía como nuevo género periodístico con un peso creciente cada vez mayor, tanto como especialidad que ha evolucionado desde necesaria a imprescindible, en las redacciones (también de televisión), pero también por parte de las audiencias que se acostumbran rápida y fácilmente a la presencia de infografías; su práctica se volvió indispensable para explicar las previsiones del tiempo, los índices económicos y las bolsas financieras, los lugares de los hechos, los mapas de siniestros y guerras, las encuestas ciudadanas y los resultados electorales.

\subsection{La gran explosión}

Desde la perspectiva del tiempo transcurrido y, a pesar de su corta edad, la Infografía moderna, la de prensa, la que ya recibe este nombre con el consenso más amplio, --aunque hay diccionarios como el de la Real Academia de la Lengua que aún no ha tenido tiempo de acogerla en su acepción más conocida--, tuvo un momento álgido que marcó un antes y un después, pero que también fue un punto de arranque, en unos medios para crecer y multiplicarse, y en otros para iniciar lo que no se habían atrevido a implementar en sus redacciones, hasta ese momento, derrotados por la evidencia: un departamento específico solo para la infografía, así de concreto, así de arriesgado para un editor celoso de gastos. Esta cota diferenciadora del antes y del después, que no se puede considerar un punto de inflexión, se dio a partir de dos fenómenos informativos sin precedentes, diferentes a todos, hasta ese momento, por su globalidad, por lo masivo de su seguimiento y por la forma de ser relatados por los medios de comunicación, en el albor de las redes y en la eclosión de las nuevas y grandes tecnologías informáticas: la Guerra del Golfo (la primera, la de Bush padre, 1991) y los Juegos Olímpicos de Barcelona (1992).

El conflicto de Kuwait fue cubierto por la CNN desde el mismo lugar de los combates, en los que ya había reporteros con sus cámaras de TV esperando al desembarco de los Marines, y dónde el primer prisionero de guerra iraquí se iba a rendir a un fotógrafo de prensa armado solo con su equipo de Réflex; esta guerra retransmitida en directo fue cubierta también, y además masivamente, por los infografistas, tanto 
en la multiplicidad de sus contenidos, como en la intensidad diaria de los acontecimientos, como en su desarrollo cronológico, como en sus valores documentales: todo el mundo aprendió lo que era un 'Harrier" y el alcance de un "Exocet". Los infografistas profesionales, periodistas ya, o casi, nos convertimos en ese momento en relatores transversales, de primera fila, de los hechos bélicos con nuestras crónicas visuales (inventamos los Partes de Guerra visuales), día a día, y así durante toda la conflagración. La CNN y los primeros, pero ya enérgicos balbuceos de la Red habían sustituido a los lentos, irregulares, inseguros y estáticos faxes como fuente de actualidad inmediata.

\subsection{Morir de éxito}

¡Fue tan rutilante!, que el éxito llegó muy pronto y de forma absolutamente arrolladora, de manera semejante a un poderoso Tsunami que arrasó las redacciones clásicas y derribó las viejas murallas que protegían los mil prejuicios de los que iban sobradamente cargados la mayoría de los redactores de pluma, que siempre habían tenido una actitud de conmiseración hacia los foto-reporteros y que ahora no tenían más remedio que considerar como a iguales, como a colegas, a otros colegas nuevos, gente de orígenes profesionales ajenos, cuando no muy extraños para ellos. Fueron dos o tres años en los que la infografía vivió procesos tan precipitados, que creció en volumen y se hizo dramáticamente imprescindible, sin apenas tener o darse tiempo para evolucionar y aprender, atropellándose a sí misma y arrollando a los infografistas que evolucionaban a marchas forzadas aprehendiendo nuevos procesos, nuevas prácticas, nuevos hábitos y sumergiéndose y desplazándose entre los veloces cambios tecnológicos, que se sobreponían los unos sobre los otros y siempre a una velocidad desmesurada.

\subsection{Sin claridad semántica}

Tanto fue así que la nueva forma de comunicación visual, que nació como todo, sin nombre, fue asociada a una terminología previa, aunque también reciente, que designaba a la locución ...infografía: ..."hacer gráficos por ordenador"..., sin especificar si eran gráficos arquitectónicos, de ingeniería, de diseño gráfico o informativos. Aún 
hoy se puede leer en el diccionario de la Real Academia Española, Infografía: ..."técnica de elaboración de imágenes mediante computadora". Sin embargo, entre los profesionales del medio adquirió pronta y definitivamente su etimología aceptada off the record a partir de las formas anglófonas, 'Info': informar y graphic: gráficamente, visualmente, con imágenes. Esta premura en el tiempo semántico ha llevado a la Infografía a situarse en un limbo de género gramatical, un sexo semántico propio definido, pues, como ya he avanzado, se utiliza por igual el término 'una infografía' en femenino, que 'un infográfico' en masculino, o un info, una info, como prefieren referirse los profesionales, que tampoco tienen claro todavía si son 'infografistas' o 'infógrafos' o 'infógrafas'. Los norteamericanos, por el contrario, lo habían resulto con premura, simplemente con su clásica practicidad semántica, infografista: 'artista'. Al margen de etimologías lo que si se ha hecho evidente es que, desde los primeros años del decenio de los noventa del pasado siglo, hasta nuestros días, la infografía ha ido creciendo en presencia, en necesidad y en práctica, se ha convertido en un clásico imprescindible en las redacciones donde lo ha podido explicar absolutamente todo, sin importar ni el origen del tema, ni las dificultades en los contenidos y además lo ha podido hacer, sola o... acompañada con texto.

\section{E1 principio de las migraciones}

\subsection{La crisis de identidad: crónica de un final anunciado}

Desde que la infografía finaliza su tránsito por las redacciones, desde sus inicios más balbuceantes y llenos de incomprensión, hasta convertirse en periodismo visual y adquirir la categoría de género informativo, ha pasado a ser un sujeto periodístico nuevo pero indispensable y habitual, y todo indica, -la necesidad ante la crisis del modelo periodístico presente, es un argumento- que su práctica va a tener un gran calado fuera de las redacciones, o al margen, del periodismo clásico.

Ser un género periodístico de nuevo cuño, en tan pocos años, es un importante bagaje para la infografía, pero el fenómeno se está desarrollando en un momento en que la madurez de la comunicación visual sigue escalando cotas, a gran velocidad, dentro y fuera de los 
medios de comunicación. Mientras, paralelamente, se están viviendo los tiempos de crisis de supervivencia en los diarios tradicionales de papel, -lo que a su vez no pasa con la televisión-, evidenciados por síntomas aplastantes (así lo dicen indicadores, analistas y cifras) de su casi irresoluble crisis, síntomas como: la caída en picado de ventas y de lectores, la irrefrenable marcha hacia la gratuidad (disimulada cada vez menos en las donaciones a instituciones, transportes, y allá donde haya potenciales lectores) y el "cul-de-sac", dramático, sin alternativa, que le supone a los profesionales tener que mantener sea, como sea, a pesar de un final amplia y largamente anunciado, la identidad y las prácticas del periodismo tradicional, conscientes de que el actual modelo ya está irremediablemente condenado (en la mayor parte de los casos) a desaparecer.

Los barómetros y las cifras de audiencia señalan insistentemente la caída irreversible del número de lectores fieles y habituales a una cabecera, usuarios fijos -que se incluyen en la versión "on-line" de estos mismos diarios- y como consecuencia sintomática la insultante delgadez dramáticamente evidente de las pilas del papel en los puntos de venta y, lo que es peor para la salud del sector, los precarios índices de inversión publicitaria, que es al fin y al cabo lo que mantiene con vida, que no ya con salud a un diario. Estos indicadores llevan a pensar que la prensa en papel va a sufrir en el menos malo de los casos, o ya está sufriendo en la mayoría de ellos, un proceso de transformaciones estratégicas, logísticas, laborales, de programación, etc, que va a comportar un proceso de reinvención, (no exento de los mayores sufrimientos para los profesionales, como los que ya se vienen produciendo desde años anteriores a la crisis del 2008), de cambio o de transformación como modelo informativo, y todo indica, que en la mayoría de los casos, en los próximos años, ya nada se va a parecer a lo que fue normal en comunicación durante el pasado siglo y los primeros decenios del actual.

\subsection{La transición}

Es este un momento en que a los comunicadores de nuevo cuño que se atreven a practicar el relato visual sistemático en las nuevas narrativas de la comunicación se les empieza a abrir tímidamente nuevas 
oportunidades fuera de las redacciones, son las puertas que comienzan a dar paso a las comunicadoras visuales hacia un nuevo modelo de trabajo, en un escenario desconocido hasta ahora, salvo en los tradicionales gabinetes de comunicación y poco más. Así, mientras el infografista, o el creador visual, a duras penas pueden ya respirar en las aguas turbias de las redacciones de la prensa de papel, y su proyección profesional en el on-line se estrella contra la realidad de la ausencia de oportunidades (una gran esperanza seguida de un gran fracaso que merecen un importante análisis aparte.

El horizonte que se empieza a vislumbrar para los comunicadores y profesionales de la narración visual, para el informador en imágenes o para el infografista, -y ya no sólo como supervivencia profesional-, es el de una sociedad con absoluta prevalencia de la información en imágenes, inmediata o no, y de lo visual como vehículo de transmisión. Todo ello se antoja como el mejor de los escenarios, aunque obviamente esté en construcción, o transformación, para que la práctica de la comunicación visual se traslade a muchos otros espacios totalmente nuevos que le permitan seguir creciendo y desarrollándose en condiciones más óptimas sin los límites que imponen los medios de comunicación actuales.

\subsection{Nuevas tecnologías, nuevos territorios}

La eclosión de las nuevas tecnologías, el acceso individual y personal permanente a la información con la oportunidad de disponer de múltiples dispositivos para ello, el desarrollo de internet y de las redes sociales, -cuyo principal vehículo de expansión se encuentra en lo visual-, y su penetración en las nuevas economías como herramienta de difusión, publicidad, transmisión, conocimiento y convencimiento, están generando a toda velocidad nuevos caminos profesionales para infógrafos fundacionales, infografistas de segunda generación, nuevos infografistas y periodistas en general: informadores y comunicadores que acepten el reto de adentrarse en las nuevas formas narrativas implícitas en la información visual.

La empresa, el marketing, los negocios y las redes, están empezando a asumir en España, con lentitud timorata, a veces calculada, y casi 
siempre, por ahora, exasperante, aunque con una curiosidad cada vez mayor, -en los EEUU ya hace tiempo que es un hecho real-, las infinitas ventajas que supone el poder comunicar visualmente, el poder conseguir explicar y explicarse, y el poder llegar con éxito hasta los usuarios utilizando la comunicación visual, y el relato visual.

\section{4. ¿Un concepto paralelo de infografía?}

En este contexto nuevo en que se mueve la infografía, a la que en ámbitos lejanos a los diarios se le empieza ya a denominar de Contenidos Visuales, o Márketing de Contenidos Visuales, y que se practica ya en muchas empresas de los EEUU, le está surgiendo un corpus teórico que explica científicamente su interés y la utilidad de su práctica. Un ejemplo de ello es la aparición de un índice de ahorro asociado a la comunicación visual, del que hablaré más adelante: el ROI, una nueva tarjeta de presentación para los gráficos que abona su rentabilidad y garantiza el éxito económico que supone el utilizar infografía donde antes sólo había publicidad, y elaborar imágenes informativas cargadas de contenidos visuales en donde antes sólo había textos y fotografías y muchas veces diseños más que dudosos.

\section{5. ¿Algo se mueve?}

En Europa, en España, las empresas, en una primera fase conservadora, tímida aún, pero cada vez más notoria, están requiriendo a formadores en infografía para conseguir un mayor rendimiento a su propio personal en áreas como Recursos Humanos, Comunicación, Márketing o Administración. Es una primera fase en la que se quiere rentabilizar las preexistencias profesionales sin arriesgarse a inversiones en territorios desconocidos. Obviamente recurrir a la formación en comunicación visual significa reconocer y admirar la infografía, intuir su utilidad y las ventajas que proporciona su uso, y valorarla como una herramienta importante, útil, incluso imprescindible, aunque obviando, por novedosa, la profesionalidad y la complejidad que subyacen detrás de ella. Obviamente también, formar a personal para reciclarlo será a todas luces insuficiente. Los departamentos de marketing y RRH no tendrán más remedio que aceptar, si quieren ser realmente más competitivos, abrirse a incluir nuevos profesionales especializados, $\mathrm{O}$ 
delegar para crear nuevos puestos de trabajo especializados y/o nuevos departamentos, ya que es mucho más rentable trabajar con un equipo propio de expertos en comunicación visual, ya sea interno o externo, que tener que acudir a remiendos de forma chapucera y a todas luces insuficientes, frente a las posibles actuaciones de una competencia más inteligente que trabaje con profesionales más preparados. Esta situación de no aceptación de que las cosas se mueven o de intentar moverlas, pero al mínimo riesgo es algo tan profundamente obsoleto y sin futuro como fue la formación de los periodistas en informática y/o programación cuando estaban introduciéndose los primeros ordenadores en las redacciones, lo que acabó dejando paso, por la fuerza de la necesidad, a los departamentos de Sistemas, hasta hoy incontestables e imprescindibles.

El punto de despegue masivo lleva dos siglos testándose en todas las novedades que acaecen en el mundo de la empresa y de los negocios y que sirven para aportar rendimiento y beneficios, y el proceso se repetirá para la utilización y desarrollo de la infografía. Es tan simple y recurrente como que cuando las empresas rivales y/o referenciales utilicen infografía, una nueva herramienta desconocida en ese contexto, para conseguir objetivos tangibles, los demás se verán obligados a hacerlo también y de la dinámica de la competencia se generará una normalidad. De lo que se trata es de ver cuando se tarda en producirse el fenómeno de una forma masiva.

\section{La infografía que viene}

\section{1. ¿Una nueva oportunidad?}

Los periodistas convencionales sin formación estética o creativa, disponen ahora de multitud de herramientas 'democráticas' a las que sumar su inteligencia informativa, eso cuando pretendan actuar como lobos solitarios, que también, porque sin duda la opción ideal es la del equipo multidisciplinar que elabore información visual también multidisciplinar: comunicador, programador, infografista, profesional de los negocios y diseñador.

En estos momentos, la Infografía, que en sus más importantes variantes actuales -una vez superado el absurdo debate identitario 
entre los mismos infografistas- ya podemos empezar a reconocer, por la frecuencia de su uso y de su presencia, con términos más definitorios como Infografía o Infografía Clásica, Infografía de Contenidos Visuales, e Infografía de Visualización de Datos o de Big Data -aplicada preferentemente al marketing-, está siendo cada vez más solicitada y utilizada en el ámbito de la empresa, tanto privada como pública. Con el desarrollo de internet que comenzó a tomar forma a finales de los años 2000 con la normalización del uso de las páginas webs, los blogs y la aparición y la multiplicación del fenómeno de las redes sociales, cualquier actividad que conlleve visualización y muy especialmente la infografía han empezado a revelarse como un fenómeno de lenguaje de recurso de utilización masiva y en contínuo crecimiento reconocible en cifras en on-line, en estos momentos expandido a lo amplio de una serie de canales nuevos que pueden utilizar las más avanzadas técnicas de marketing de contenidos visuales (y entre ellas la infografía como herramienta) para llegar a muchos más destinatarios.

\subsection{Una buena infografía es un importante activo para un negocio}

Actualmente, la cada vez más frecuente utilización de la infografía, perceptible en las astronómicas cifras de Google, para incrementar la visibilidad empresarial en internet debería llevar a cualquier empresario o profesional de los negocios a asumir que la infografía ya se ha convertido en un activo muy valioso para sus números como demuestran las cifras en el país que antes y con más convencimiento ha desarrollado el uso de la infografía al servicio de la empresa: los EEUU. Pero también y al igual que cualquier otra inversión, los empresarios más hábiles deberían comprobar el valor añadido real midiendo su valor en términos de rentabilidad. $\mathrm{Y}$ es aquí cuando aparece el nuevo baremo económico asociado a la infografía: el ROI.

\subsection{E1 ROI no miente}

Estas iniciales son un indicador de éxito o fracaso. El ROI (Return On Investment) o retorno, o rendimiento de la inversión de una infografía, se expresa técnicamente para una operación como la fracción entre los ingresos obtenidos menos la inversión, dividido por la propia inversión 
o coste de la infografía, aunque una inversión de mercadotecnia en gráficos puede tener beneficios a largo plazo y el coste puede reflejarse o materializarse de diferentes formas como la atracción de visitantes a la página web o al blog, sus interacciones o leads, el aumento de simpatizantes de una marca y la posibilidad de que estos a su vez, se conviertan en posibles usuarios o clientes de los productos o servicios ofrecidos, o mejor aún, los compartan con otras personas gracias a la información que les aporta la infografía. En otras palabras, el ROI nos permite evaluar la utilidad de una infografía para obtener buenas noticias, ya sean financieras de beneficio o rendimiento directo o también las que nos empiecen a dar indicios o certezas de muy buenos resultados para el futuro. Por otro lado, el mercado ha comprobado que la infografía es el recurso "que menor coste por impacto tiene y el que mayor redifusión consigue" y además en el caso de internet, redes, webs, blogs, cuenta con una "perdurabilidad en el tiempo absoluta". Muchas ventajas y, de momento, cero inconvenientes. Con todo, quizás el mejor escenario para la infografía reside en su independencia, como defiende el experto en redes y gran mentor de la infografía como herramienta de visualización Alfredo Vela, hay muchos casos al respecto: "La infografía como tal, puede tener vida propia. De hecho, hay un buen número de publicaciones que son la infografía y, como aditivo, algo de texto de introducción a la misma".

\section{4. ¿La infografía puede aportar algo importante a un negocio?}

Las infografías gozan del prestigio que les ha dado "el componente visual de la información" ya que, como comenta Alfredo Vela "sin temor a equivocarme, la gente se lee la infografía y rara vez el texto que la acompaña". En El Periódico de Catalunya, diario de Barcelona en el que yo mismo desarrollé una parte extensa y muy importante de mi carrera profesional, se habían hecho varios experimentos sobre el tema, y el resultado era obvio: una mayoría de los lectores miraban primero las páginas con infografías y puestos a leer, después de los titulares, devoraban las infografías preferentemente antes que los textos que las acompañaban. Esto es lo que aún no entienden, o no se han preocupado todavía en entender la mayoría de los responsables de empresa españoles a la hora de barajar la posibilidad de encargar una infografía. Muchos de ellos, en su analfabetismo -y quizás también 
ignorancia- visual aún piensan que comunicar visualmente, narrar con imágenes, practicar infografía es simplemente utilizar dibujos, lo que para su preparación profesional que descansa en los números y en los textos, o como mucho en visualizaciones hieráticas, frías y sintetizada reducidas a los indicadores económicos y a una manera de expresarse prefabricada en plataformas como Google, por ejemplo, es una práctica menor, y además los dibujos sin más, a su vez, siempre han tenido muy mala prensa. Este fenómeno de absoluta ignorancia, o resistencia a la reflexión de negocio, que siempre se ha dado en el principio de todos los grandes avances en materia de comunicación, es el dominante en todas las grandes escuelas de negocios donde aún no han descubierto las utilidades de la imagen al servicio de la empresa y donde se explican todo tipo de estrategias de marketing menos las visuales relacionadas con la infografía. Es dramático el constatar como en la alta enseñanza de negocios se le empieza a reconocer una relativa presencia, que tampoco es demasiada, la verdad, al VisualThinking que puede ser, a la postre, uno de los puntos de partida para que cualquier profesional de los negocios pueda llegar pensar en términos infográficos.

Así pues, y lamentablemente, las cosas van muy despacio, aunque van, pero en general se ignora a nivel de empresa que la infografía se puede convertir en uno de los soportes más fundamentales a la hora de diseñar estrategias de negocios. Este es un fenómeno de incultura de empresa más ligado al que vende que al que compra, como las redes ya están dejando muy claro hace tiempo, el éxito de la infografía se juega más en el terreno de los potenciales usuarios, clientes o consumidores que en casa de quién está en condiciones de producirla para obtener un claro beneficio, ignorando su uso o, lo que es lo mismo, negándole la importancia que se merece. Ello a pesar de que, como afirma con datos recientísimos Alfredo Vela, "la infografía junto con el vídeo son los dos formatos que mejor aceptación tienen", y añado yo: mayor implantación en internet.

\subsection{Para muestra un botón, aunque las hay a miles}

Un gran amigo mío, Joan Corbera, que lamentablemente nos dejó hace unos meses, hombre muy inteligente, culto y un gran experto en comunicación para los negocios, creía profundamente en la infografía 
hasta el punto de crearle un espacio en su Máster para Comunicación de Empresa en la Universidad de Barcelona IL-3. Corbera me encargó hace poco más de un año un PowerPoint, en este caso un Keynote, con lenguaje infográfico en cada fotograma para acompañar una conferencia en la escuela de negocios más importante del Estado, obviamente la manera de diseñar las slides no tenía nada que ver con el discurso visual habitual, caótico, desordenado, recargado, feo, típico de las presentaciones, que se acostumbran a encargar a gabinetes de comunicación, secretarias (que no tienen por qué hacerlo) o, en el mejor de los casos, a diseñadores, lo que tampoco es una solución porque, en general, no poseen grandes conocimientos como comunicadores. El resultado del experimento fue más que apoteósico. La conferencia tuvo un gran éxito entre muchas de las mentes más relevantes de los negocios en España, que aplaudieron y encomiaron aquella presentación, porque a la información impartida por el conferenciante, que era a su vez muy brillante, se le proporcionaba un plus en un soporte visual, que ayudaba a enfatizar su comprensión: se les hablaba con infografía en cada diapositiva.

\section{La infografía: ¿un negocio para el infografista? 7.1 Ser infografista fuera del papel sigue siendo difícil}

La incomprensión profesional hacia el infografista se encuentra en niveles semejantes que la incomprensión a las bondades de su trabajo y a los beneficios que reporta. En estos momentos el profesional de la comunicación visual ha de utilizar argumentos más que didácticos para convencer de las ventajas de la utilización de infografías, que por otra parte suelen gustar y mucho, pero no hasta el punto de encargarlas, aunque afortunadamente no sea así en todos los casos. El infografista constata cada día que la emprendeduría y el riesgo, virtudes legendarias en muchos de los grandes empresarios, que hacen gala de poseerlas en abundancia, lamentablemente son como un armario con capacidad para muchas herramientas de negocios, pero en cuyos cajones no cabe la infografía. Esta misma ignorancia visual generalizada, también había afectado al mundo del diseño gráfico, no hace muchos años, por ejemplo, cuando tuvo que apostar muy fuerte para superar el gran vacío por parte de las empresas frente a la obviedad de la trascendencia cada vez mayor de las identidades corporativas y las imágenes de empresa. 
Lo que antaño no se comprendía, o parecía una frivolidad es ahora una necesidad prioritaria para cualquier marca en una práctica absolutamente normalizada en que, como en la infografía, también se explica visualmente casi todo, o todo.

\subsection{Caminos que se abren}

Sin duda la opción que se sugiere ahora mismo con más perspectivas, si atendemos a las cifras, es la de la infografía específicamente creada para redes, blogs e Internet, que también es la más utilizada para el mundo de los negocios. Esta práctica infográfica destaca por ser un recurso muy económico para quien la requiere, los valores de su ROI son idóneos y nos hablan siempre de beneficios, aunque hay que añadirles pequeñas inversiones, que tampoco acostumbran a ser importantes, para su promoción y para llegar a conseguir la viralidad en internet, donde se precisa frecuentemente de la colaboración de elementos externos como seguidores, amigos, e influencers del producto que se quiere vender. Pero estas son fórmulas que los mecanismos del novísimo Inbound marketing ya trabajan con total fluidez.

Si seguimos analizando perspectivas para el desarrollo de la infografía y de la profesión del infografista lejos de los medios tradicionales de comunicación, hay que tener en cuenta que actualmente se está produciendo un fenómeno infográfico muy potente, reciente en sus orígenes y en su desarrollo, pero cada vez más consolidado en su utilización por un sector cada vez más importante del mundo de la empresa. A esta nueva infografía que trabaja con un volumen importante de datos y con una serie de procesos complejos de scraping, minería de datos, o periodismo de datos, se le denomina: Visualización de Datos, o Big Data, y es una práctica infográfica ideal para sociología, economía, finanzas y allá donde haya que mover una gran cantidad de información para obtener conclusiones visuales inmediatas, esencialmente numéricas y que está introduciéndose con gran fuerza en el mercado. Ahora mismo, la salud de la Visualización de Datos parece ser más que excelente, aunque el control de su práctica es notorio que se le escapa todavía, en gran parte, a los infografistas tradicionales, como se hace evidente al repasar la mayor parte de los resultados visuales de los trabajos realizados con programas, por otra 
parte, indispensables, como Tableau (otro tema importante para analizar y debatir). Este es un camino que, al menos en España, ya está activado y bien dirigido también por algunas empresas, bien consolidadas, que ya trabajan a fondo en este tipo de infografía, pero donde aún queda mucho por desarrollar. En cualquier caso, los procesos de reflexión y praxis que desarrolla un infografista en sus trabajos de comunicación visual habituales o en lo que ya se puede denominar como Infografía Clásica, son, en principio, semejantes cuando se trata de desarrollar una infografía de Big Data aunque las presentaciones finales poseen otra especificidad y donde las dimensiones de los resultados requieren de la interactividad y por tanto los equipos de trabajo deben de incrementarse frecuentemente con el apoyo de programadores, o técnicos informáticos especializados.

En estos momentos, además de los cursos de formación para empresas que antes mencionaba, hay diferentes caminos que también empiezan a funcionar tímidamente para cualquier comunicador visual, todos ellos son complejos y hay que convencer a los que han de hacer los encargos de las ventajas y bondades de utilizar las infografías. En infografía clásica se está trabajando y mucho para las redes, como ya he avanzado, pero también se abren tímidamente las posibilidades en cualquier medio en donde se dé la necesidad de mejorar la comunicación a partir de las nuevas técnicas y de las nuevas tecnologías visuales, como es evidente en los gabinetes de comunicación y en las agencias de prensa, en las webs, en los blogs, en todo tipo de publicidad, en infografía editorial, en presentaciones de empresa, internas y externas, en documentos de todo tipo, en cualquier actividad empresarial, privada o pública en donde se incluyen publicaciones también externas e internas, y para todo tipo de profesionales, para explicar su trabajo mejor y facilitar cualquier tipología de actividad profesional en contacto con el público (médicos, abogados, economistas), etc. En suma, la infografía tiene un gran recorrido y va a funcionar muy bien en aquellos contextos en los que es necesario explicar cosas a partir de la traducción de contenidos en imágenes, de la velocidad de transmisión y de lectura, de la eficiencia y corrección, y de la estética, y esto es lo que el profesional que trabaja con la comunicación visual debe de saber explicar y explicarse a sí mismo para conseguir ser comprendido. Una 
tarea realmente muy difícil en primera instancia, aunque todo ya se está moviendo.

\section{3. ¿Y se puede hablar de precios?}

Todo empresario, emprendedor, responsable, solvente, sabe perfectamente cuál es el precio (o la horquilla de precios) de un electricista o de un pintor y no acostumbra a fruncir el ceño cuando se enfrenta a los presupuestos relativamente altos de los profesionales con los que está acostumbrado a negociar. Un problema muy grave para la comunicadora visual es cuando una vez ha conseguido convencer a un promotor de la utilidad de su trabajo, éste le solicita los precios. La ignorancia de tarifas de mercado y la lógica de las mismas, en una profesión tan nueva como ésta, adquiere tintes frecuentemente dramáticos, cuando no insultantes, en comparación con otras prácticas profesionales. Se le hace también sumamente complejo a un infografista el tener que calcular a priori el coste exacto de su infografía. Se suele dar con frecuencia la situación de que cuando el infografista pregunta a su interlocutor sobre cuál es el presupuesto previsto, de cara a estudiar las posibilidades de adaptación a sus honorarios, prácticamente siempre se sigue obteniendo el silencio como respuesta. Y lamentablemente también es cierto que, ante cualquier precio, alto, medio, o bajo, que el profesional infografista proponga, frecuentemente le va a parecer muy caro a quienes hacen el encargo, a pesar de que, si se comparan los precios de las infografías con los de otras plataformas de publicidad o de comunicación, sigan siendo comparativamente mucho más bajos.

\section{4. ¿Y cuál y bajo qué conceptos debería estar el coste de la creación de una infografía?}

Los factores clave para calcular los precios para una infografía, aún y siendo muy diversos, se pueden reducir básicamente a dos que pueden incluir a todos los demás: la complejidad del trabajo y el tiempo invertido en la realización de la infografía. Ambos se pueden desarrollar muy sintéticamente a lo largo de estas cuatro fases. 
-Primera fase:

Los trabajos previos que incluyen marketing y difusión, publicidad, evaluación de costos, presupuestos, anteproyectos, visitas, reuniones y/o desplazamientos, actividades de mercado, contratación, etc., y que pueden volver a repetirse en las otras tres fases.

-Segunda fase:

El inicio del proyecto infográfico propiamente dicho, o sea, partir del desarrollo de una serie de trabajos previos para planificar, reunir la información y prepararla para empezar a narrar visualmente. Estas actividades iniciales incluyen recabar los datos, investigar, almacenar ordenar, estructurar, jerarquizar, pulir y realizar una serie de esquemas iniciales de análisis, que pueden incluir un proceso de guión e incluso el desarrollo de una serie de historias o relatos Storytelling de los contenidos y del programa para empezar a estructurar el proceso de diseño propiamente dicho. En definitiva, si se le puede llamar así, la locución visual que puede utilizar ilustraciones, dibujos, textos, mapas, fotografías, vídeos, audios, animaciones, interactividad y múltiples herramientas infográficas para construir un relato lo más visual posible.

-Tercera fase:

El desarrollo del trabajo artístico-plástico-tecnológico que a partir de la información de la fase anterior pasa prioritariamente por la creación inicial de un libro de estilo (si no existe ya uno en esa marca o proyecto), al que se será siempre rigurosamente y exactamente fiel para evitar desconcertar al usuario o crear una infografía compleja e inapropiada. A partir de aquí viene la traducción visual del proyecto al que hay que enriquecer con aquellos valores estéticos-plásticos creados por el propio narrador, cuando posee la formación y/o los conocimientos apropiados, me refiero a la utilización de programas clave como Illustrator, Photoshop, After Effects, Indesign, Tableau, Keynote, PowerPoint, IMovie, etc; aunque también se pueden utilizar otros muchos recursos prefabricados en aplicaciones existentes en el mercado que facilitan el desarrollo del trabajo infográfico para comunicadores que no poseen aquellas habilidades o el entrenamiento del grafismo tradicional como son Canva, Venngage, Visme, Infogr.am, Creately, Sketch, Piktochart, etc.

Se trata de que los recursos visuales y su ordenación estructurada 
seduzcan, atraigan o simplemente induzcan a la curiosidad a los futuros usuarios pues es la fuente fundamental del éxito de la infografía. No hay que perder de vista que se puede incluir en el proceso de trabajo la aportación de otros especialistas como técnicos de sonido e imagen, ilustradores, expertos en 3D, programadores, etc. También hay que incluir los costes de los materiales que sean necesarios adquirir y especialmente de aquellos donde haya que hacer uso de los derechos sobre su libre utilización con fines comerciales, como fotografías, ilustraciones, iconografías, tipografías, vídeos, y su acceso a través de los bancos de imágenes, o de otros orígenes, aunque cada vez existen más mecanismos, aplicaciones específicas y recursos prácticos que proporcionan materiales gratuitos.

\section{-Cuarta fase:}

Edición, análisis, traslación a los medios correspondientes, registros, entrega, y por supuesto, el cobro de los trabajos realizados.

Como decía anteriormente, el mercado español se encuentra ahora mismo huérfano de tasas habituales, más o menos fijas establecidas. Es cierto también que pocos emprendedores pagan un precio justo, (aunque sigue siendo bastante justo lo que pagan), que tenga que ver con los dos factores anteriores de dificultad y tiempo; nótese que no incluyo todavía un plus de formación híper especializada como si se da en el caso de lo que cobran otros profesionales como arquitectos y médicos.

Ante la ausencia de precios reglados, usuales o de referencia y la ignorancia global sobre los mercados, recurro a un caso, como ejemplo, en el que los precios si están preestablecidos como son los EEUU. Las tasas de mercado de una infografía, que en estos momentos de irrupción y desarrollo, y atendiendo a los factores anteriormente comentados, pueden oscilar entre: $100 €, 250 €$, 500€ como precio medio; y $1.000 €$ para grandes trabajos o grandes proyecciones, no deberían asustar a las empresas que contratan el diseño de infografías ya que no son objetivamente tarifas muy grandes para un producto que queda en propiedad permanente, que se puede retocar y reutilizar y que, en el caso de internet, ya no puede borrarse nunca más. Hay que añadir a todo esto el plus, como nos explica la experiencia de mercados, de que, de su uso cotidiano, no solo se incrementa significativamente 
el conocimiento y la retención en la memoria de cualquier marca, si no que cuando se trata de redes o de internet se favorece que el tráfico y las acciones de los medios sociales vayan dirigidos directamente a la fuente de la información en sí, es decir, a los sitios web.

\section{Epílogo para el futuro}

\section{1. ¿Las Infografías sirven para vender?}

Las infografías son pues, como hemos intentado poner en evidencia, un presente importante con un gran camino recorrido y, sobre todo con un futuro más que esperanzador. Las infografías si bien tienen un carácter informativo, y de hecho, por definición, implícitamente informan siempre, no se cierran a un ámbito concreto, lo que significa que "se puede hacer infografías de todo", como siempre defendemos, todo es absolutamente infograficable. Pero si analizamos su vertiente comercial. ¿La tiene?, como defiende Alfredo Vela con cifras: "Sin duda. Forman parte de la estrategia de marketing de contenidos y de marketing de atracción" lo que, como todo "si se ejecutan bien al final derivan en ventas". De hecho, sigue Alfredo Vela sobre la vertiente más lucrativa de la práctica de la infografía, y de hecho su mejor garantía de futuro, "las infografías están todavía por explotar" aunque es cierto que "su crecimiento en los últimos años ha sido impresionante". ¿Han alcanzado la cima, por ejemplo, en internet? "creo que todavia no hemos llegado a lo más alto. Se producirá en los próximos años" con formatos como "infografías animadas e interactivas".

\section{2. ¿Preguntas para plantear y temas para debatir?}

Llegados a este punto podemos plantear grandes temas a debatir asociados al desarrollo de la infografía fuera de las redacciones y/o su permanencia en ellas y que podrían ser la columna vertebral de un estudio más profundo sobre esta temática que desgraciadamente, en general, posee una mínima bibliografía en lengua castellana aunque son excepciones que explicitan muchas ideas de peso alrededor de los conceptos de infografía, periodismo y comunicación visual, como son los libros de José Luis Valero, José Manuel de Pablos, o Alberto Cairo. 
-La infografía periodística tradicional y en el diseño editorial:

Mientras persista el modelo actual de prensa escrita, o si se produce cualquier tipo de cambio de rumbo, que es de esperar por el bien de tantos profesionales del periodismo abocados a un futuro más que incierto, la infografía, aunque de forma precaria, aún tiene cosas que decir. No se crean nuevos departamentos de infografías, como no se crean nuevos diarios y por tanto ésta es una profesión que se extingue en cuanto a práctica, a no ser por la práctica de la docencia que crea curiosidad, cuando menos, alrededor del tema.

-La infografía en la prensa on line:

Está comprobado estadísticamente la obviedad de que en estos momentos se realizan muy pocas infografías en los grandes medios online continuadores de la prensa generalista (no es exactamente así en los pequeños medios, en la prensa especializada, o en la que ha nacido específicamente en internet), a causa del alto precio para mantener un departamento con un número de profesionales que garantice fluidez, por la inmediatez y la celeridad que la red exige en las informaciones y porque sólo se pueden realizar reportajes a largo plazo con un mínimo de solvencia infográfica. La interactividad está prácticamente estancada, cuando no desaparecida, y actualmente se ha vuelto las animaciones, cuando no a la infografía estática para descargar. Sin embargo, también se han desarrollado aplicaciones gratuitas en internet como Canva, Venngage y Visme que permiten a un estudiante de periodismo o a cualquier profesional no especializado y sin conocimientos de programación, construir pequeñas infografías con interactividad e incluso dar animaciones a sus trabajos, lo que es un plus nada desdeñable.

\section{-La docencia:}

Es la gran garantía de permanencia y de futuro y evita el frecuente intrusismo de profesionales mal preparados para la comunicación visual, lo que incluye a muchos diseñadores. Lamentablemente se enseña poca o ninguna infografía en la mayor parte de las facultades de periodismo, en las de diseño y en las de negocios, que son las fuentes naturales y mayoritarias para practicar esta profesión. En mi caso en particular, tengo el privilegio de estar impartiendo infografía a alumnos de periodismo en la UAB (Universidad Autónoma de Barcelona), UVic 
(Universidad de Vic) y lo he podido hacer también en la UPF (Universidad Pompeu Fabra), marcando siempre las tintas en los aspectos visuales y estéticos para este perfil de estudiantes. También enseño infografía a alumnos de último curso de diseño en la escuela EINA, como lo hice en las escuelas Elisava y BAU, de Barcelona, marcando aquí las tintas, por el contrario, en la vertiente informativa. De impartir la enseñanza de infografía con continuidad se desprende que antiguos alumnos trabajen en medios de comunicación y que algunos de ellos hayan podido conseguir, incluso, premios internacionales para profesionales del diseño de prensa como son los European Newspaper Award. La docencia es la mayor esperanza de futuro, aunque debería crecer, y mucho, la apuesta por parte de los centros académicos que en su mayor parte no contemplan la infografía en sus programas.

-Formación de empresas

Como comentamos más arriba, esta es una fuente importante de difusión de la infografía, aunque se revela insuficiente. No obstante, se está produciendo cada vez con más asiduidad la demanda de cursos de formación para empresas públicas y privadas lo que es sin duda una herramienta de futuro.

\section{-Masters y postgrados}

Otra forma de convertir en familiar la infografía, en potenciar su uso y en permitir entender su necesidad es su enseñanza en cursos de postgrado, de periodismo, de comunicación, de economía, de redes, de empresa en general y de cualquier otra profesión en la que la infografía pueda ser de utilidad. Tímidamente se ha dado un crecimiento en la demanda de profesores, pero es muy difícil encontrar cursos de postgrado que incluyan infografía, al margen de excepciones esperanzadoras como son los cursos sobre redes que imparten figuras notables como es el caso de Pedro Rojas.

-Equipos de trabajo y especialización

En los tiempos que corren es muy importante la construcción de equipos de trabajo con miembros especializados en las diversas materias que confluyen en la elaboración de las infografías acorde a las 
nuevas tecnologías y las que ya están llegando, desde periodistas hasta informáticos.

-Recuperar la Visualización de Datos

Esta es una disciplina visual que está creciendo muy rápido y, a causa de la necesidad perentoria por parte de las empresas, muy al margen de la infografía y de los infografistas. La Visualización de Datos, disciplina compleja que parte de la ciencia de datos Big Data, exige una compleja formación propia que ha dado lugar a cursos especializados y en este caso sí existe un buen número de ellos. Por desgracia la elaboración de gráficos de datos está monopolizada, en gran parte, por profesionales frecuentemente alejados del mundo de la comunicación visual lo que se refleja en los resultados finales de importantes trabajos de documentación con grandes volúmenes de información, pero más que cojos en cuanto a respuestas visuales. Por definición, esencia y objetivos, la Visualización de Datos coincide con la infografía, es más, para la mayor parte de los profesionales de esta última, el debate sobre su pertenencia o no a la práctica de la comunicación visual, que lo hubo, ya está cerrado. Como conclusión es muy importante sumar los profesionales de la infografía a el desarrollo de los programas de Visualización de Datos en tanto que visualización de información, aunque la diferencia esté en el gran volumen de ella.

-Modelo de empresa

Finalmente, es muy importante que los profesionales de la infografía se constituyan en parte integrante de los departamentos de comunicación de las empresas, pero que también puedan constituir ellos mismos sus propias empresas con equipos transversales y multiespecializados, con por ejemplo comerciales y gestores, que puedan practicar actividades de mercado para difundir y para asentar el uso cotidiano de la infografía.

\section{Apéndice. Mi experiencia profesional \\ 9.1. Infografía transversal}

Cierro este conjunto de reflexiones con una muestra seleccionada de mi trabajo infográfico realizado fuera de la redacción de un medio tradicional, por tanto, una praxis relativamente periodística, pero que me ha servido, junto con otras muchas experiencias paralelas y multitud 
de datos recabados, aunque todavía no publicados por la novedad de la situación, para reflexionar sobre las ideas vertidas en el presente estudio. Esta situación laboral como francotirador y freelance de la infografía, entre dos mundos de práctica profesional tan opuestos, la inicié en abril del 2014, y tras cuatro años de incrementar mi actividad en volumen y en heterogeneidad y tipologías de contenidos, he podido constatar la evidencia de las ideas que defiendo en ese texto, a pesar de la ausencia de un escenario, aún en construcción. Los resultados no son exitosos para el desarrollo de la profesión, pero sí han sido esperanzadores. La apuesta, la ilusión y el empuje de profesionales enamorados de la infografía, pero no infografistas, lo que es muy de destacar, como José Luis Valero, Aitor Castañeda y Beatriz Elena Marín me han permitido tener la fortuna de poder mostrar mi trabajo más reciente en cinco exposiciones, en los dos últimos años, la última de ellas en octubre, en la Universidad Pontificia Bolivariana de Medellín, Colombia. Me siento ahora mismo, otra vez, como un pionero (aunque hay otros colegas, no muchos aún, que también están desarrollando su trabajo fuera de los diarios, por supuesto) y albergo sensaciones parecidas a las que tuve a finales de los años 80 cuando empecé a navegar en una profesión que aún no existía como tal, y viví el tránsito de la artesanía productiva manual a trabajar con los primeros ordenadores, enseguida el Mac SE, en un diario, luchando en múltiples frentes para que la práctica de la infografía se convirtiera en un hecho normal y aceptado, como se ha ido explicando al principio de este trabajo.

\subsection{Experiencias positivas}

Estos cuatro años que han estado plagados de problemas, incomprensiones, esfuerzos, dificultades propias de trazar y abrir rutas inexistentes, sin una infraestructura cohesionada, me han permitido tomar conciencia y ser consciente de lo que explico y defiendo a partir de vivir momentos muy especiales que me animaban a seguir en la senda de la infografía, a pesar de todo. Ha habido momentos muy importantes y especialmente didácticos en cuanto a utilidad pública de la comunicación visual, como cuando el Parlamento de Cataluña aprobó con gran unanimidad una Ley de la Vivienda, que había sido explicada a los parlamentarios a partir de una colección de infografías 
que luego sirvieron para ilustrar a los ciudadanos en que les beneficiaba su ley y cómo acogerse a ella. O también cuando una colección de infografías pudo ayudar a una empresa de construcción a conseguir un segundo puesto en un concurso multinacional en París. O infografías de salud para que la sociedad pueda entender temas que la afecta como son los peligros potenciales del abuso de carnes procesadas, $\mathrm{O}$ desmantelar científicamente la mala prensa, frecuentemente no justificada, de los productos fitosanitarios. Si a todo esto se le junta un episodio, muy reciente, por cierto, en que una persona, un particular, totalmente desconocido, me llamó para encargarme una infografía para facilitar un trabajo de abogacía, con el fin de regalársela a un profesional, amigo suyo.

En todo este tiempo ha habido infografías y presentaciones para instituciones públicas, de salud, de turismo, para explicar espectáculos, para enseñar a cocinar o a preparar cócteles, para ilustrar sobre cómo una institución pública aconseja la prevención de incendios forestales o, como no, para enseñar el funcionamiento, los formatos, los buenos usos, o vender en redes, y también ha habido inventos infográficos, sin precedentes en internet, como Memorias Visuales de empresa y Catas Visuales de productos enogastronómicos, que forman parte del apéndice de este trabajo como ilustración del mismo.

Aunque quizás, y como conclusión que lo explicita todo, está el que quizás ha sido uno de mis mayores momentos de satisfacción personal durante todo este tiempo, y el que me indicaba que tenía de seguir por esta senda. Sucedió en el Gran Teatre del Liceu de Barcelona, entidad para la que estoy realizando infografías, cuando Terry Gilliam, fundador de Monty Python, me confesó que gracias a las infografías que le regalé sobre sus escenografías operísticas: "Ahora podía entender globalmente su trabajo". 


\section{Bibliografía}

Cairo, A. (2013). "The Functional Art". An introduction to information graphics and visualization. Berkeley (Estados Unidos): New Raiders

Cairo, A. (2008). Infografia 2.0 : visualización de información en prensa. Madrid: Alamut

Colle, R. (2004). Infografía: tipologías. Revista Latina de Comunicación Social, 58. Recuperado el 20 de octubre de 2017 de http://www.ull.es/publicaciones/latina/latina art660.pdf

De Pablos, J. M. (1998). Siempre ha habido infografía. Revista Latina de Comunicación Social, 5. Recuperado el 7 de noviembre de 2018 de http://www.ull.es/publicaciones/latina/a/88depablos.htm

De Pablos, J. M. (1999). Infoperiodismo: el periodista como creador de infografía. Madrid: Síntesis. Recuperado el 7 de noviembre de 2018 de http://www.ull.es/publicaciones/latina/a/88depablos.htm

Leturia, E. (1998). ¿Qué es infografía?. Revista Latina de Comunicación Social, 4. Recuperado el 7 de noviembre de 2018 de http://www.ull.es/publicaciones/latina/z8/r4el.htm

Valero Sancho, J. L. (2001). La infografía.Técnicas, análisis y usos periodísticos. Barcelona: Universidad Autónoma

Valero Sancho, J. L. (2009). La transmisión de conocimiento a través de la infografía digital. Ámbitos, (18), pp.51-63. Recuperado el 23 de enero de 2013 de http://grupo.us.es/grehcco/ambitos18/04valero.pdf

Valero Sancho, J. L. (2012). Infografía Digital. La Visualización Sintética. Barcelona: Bosch. Recuperado el 7 de noviembre de 2018 de http://grupo.us.es/grehcco/ambitos18/04valero.pdf

Zamarra, M.M. (1996). La Guerra del Golfo en la integración de la infografía en la prensa diaria. Tesis doctoral. Madrid: Universidad Complutense 


\section{VI}

\section{Aproximación a una taxonomía de la visualización de datos}

José Luis Valero Sancho (๑). Departamento de Comunicación Audiovisual y Publicidad. UAB, España

joseluis.valero@uab.cat

Jordi Català Domínguez (๑). Departamento de Comunicación Audiovisual y Publicidad. UAB, España jordicatalad@gmail.com

Beatriz Elena Marín-Ochoa (๑). Departamento de Periodismo. UPB, Colombia. Beatrizemar@gmail.com

Resumen. Con los nuevos documentos visuales existe una cierta tendencia a utilizar los conjuntos ingentes de datos con los que construir documentos útiles en diversos sentidos. Para ello se elaboran de forma gráfica presentaciones basadas en sus fuentes y así se pretende resaltar contenidos lo más cercanos, significativos y didácticos para que los intérpretes los puedan comprender. Este documento pretende poner un cierto orden a la polisemia o sinonimia de términos que se suelen emplear en el ámbito de las rutinas de producción y al mismo tiempo elaborar un cierto análisis prototípico de los diversos documentos presentados en las llamadas visualizaciones de datos. La clasificación taxonómica evidencia que hay una contribución a los estudios de comunicación visual y un cierto interés por este tipo de presentaciones de fácil interpretación, rápida producción y bajo coste cuando la programación tecnológica se reutiliza para otro tipo de contenido. 
Palabras clave. Visualización, infografía, visualidad, relato visual, datos.

\section{Introducción}

$\mathrm{H}$

ACE mucho tiempo que el ser humano descubrió el portal de entrada de conocimiento ocular. Ha sido tan importante en el pasado que el planteamiento de los modelos multimedia en la época de los cibermedios ha establecido unas ciertas prioridades en los lenguajes visuales. Lo que no se puede tocar, oler, oír o degustar, en la mayoría de los casos puede ser representado visualmente.

Neuropsiquiatras como Xaro Sánchez (2007) entienden que por la vista y también el arte penetra una gran parte de los conocimientos de cualquier web. Esta comunicación visual es al mismo tiempo también artística y por ello hoy día se presentan reflexiones llamativas como que el arte debe servir fundamentalmente para adquirir conocimientos, incluso por delante de las estéticas con las que está unido inseparablemente.

Pero existen dos tipos de arte, se contrapone el llamado facts graphics o graphics information o información gráfica, que se contrapone al flavor graphics entendido como grafismo unicamente decorativo. Dicho, en otros términos, en el mismo documento coexisten las propiedades visuales de los contenidos y las propiedades visuales del arte de las representaciones (Cairo, 2011: 19).

Unos grafismos se parecen a otros, pero los contenidos son distintos y la representación para los significantes también. No es lo mismo un desarrollo médico que uno meteorológico, el primero se nutre de avances o principios científicos y el segundo de datos que proporciona el medio natural continuamente, unas veces reflejan el asunto clave significativo, con formas poco figurativas de la naturaleza y otras la reflejan algo. Unas veces domina el contenido y otras el arte. Sin embargo, hoy día hay una gran preocupación por descubrir y visualizar conocimientos en las bases de datos, basados en la tecnología de las redes neuronales no supervisadas (Sotolongo, Guzmán y Carrillo, 2002: 477). 
$\mathrm{El}$ adjetivo visual posee ciertas polisemias y sinonimias. Está bastante extendida cierta confusión en los conceptos pues se juntan en el mismo las propiedades oculares, los modernos procesos y la necesaria alfabetización visual de la audiencia.

Visualidad y visualizar no se refieren a lo mismo, se emplea el concepto visualidad para describir un efecto agradable al construir objetos vistosos, en cambio empleamos el verbo visualizar para referirnos al trabajo de elaborar mediante representaciones ópticas fenómenos de otro carácter, como vienen a diferenciar los diccionarios de referencia.

En el primer caso la referencia es al producto artístico elaborado con el fin de crear sensaciones estéticas de tipo connotativo (flavor graphics, fine art, etc.) mientras que en el segundo es la actividad consistente en generar un producto que reproduce unas ideas comprensibles para el conocimiento denotativo. En una representación las dos propiedades se funden.

La llamada visualización es una de las más importantes características que tienen las representaciones visuales, no hay propiedad comunicativa más importante y poderosa que la planteada para ser entendida por los intérpretes. El ser humano la ha usado siempre para hacer perdurar los mensajes a partir de determinados lenguajes decodificados por la vista.

Así cuando se visualiza mentalmente el arte, la caza o la forma que presenta un animal en sus embestidas se está imaginando la secuencia escénica del animal sin tenerlo delante, basta con cerrar los ojos y se entiende que reproducimos y comprendemos gracias a la experiencia y la simulación morfológica y de sus movimientos como es.

De esta forma dibujó Alberto Durero su famoso rinoceronte, animal que no había visto nunca antes, bastó que los exploradores se lo describieran, lo visualizó mentalmente y lo dibujó después. ¿Cómo iba a copiar dicho animal si no lo visualizaba mentalmente? Igual hizo Julio Verne con sus viajes sin haberlos experimentado antes. La visualización es por tanto una propiedad de los seres humanos capaz de generar 
imágenes mentales y visuales al transformar las primeras en las segundas.

La visualización también es distinta según el soporte y la representación que realiza el interpretante. Se elabora con sistemas captados o sintéticos, cuando es captada, tiene limitaciones espacio temporales que impiden la optimización pues no abarca todos los tiempos de la naturaleza, realidad o sus momentos clave limitados a lo visible, pero al fotografiar o videografiar también se puede transformar sintéticamente.

La síntesis gráfica o visualización sintética consiste en un conjunto de propiedades que buscan representar de forma completa la realidad y elaborar el relato (descriptivo, narrativo o interpretativo) de un suceso, no únicamente la naturaleza visible. Las formas tipográficas o caligráficas se sustituyen por lenguajes icónicos y sistemas de visualización y visualidad infográficos. Pueden elaborarse de muchas maneras a partir de fuentes procedentes de sucesos con sus hechos fortuitos, actos de seres vivos, documentos, datos almacenados o generados en el presente y objetos materiales o no, de procedencia diversa, a los que podemos llamar cosas. De ello hemos hablado en otros documentos (Valero, 2012a y 2008).

Por otro lado, en la realidad existen manifestaciones naturales, infraestructurales o inmateriales, que tienen propiedades referentes, que a menudo pueden ser medidas y proporcionan datos que permiten estudiar tendencias, predicciones o patrones relacionales sobre los mismas. "Las interfaces gráficas interactivas en general y la aplicación de visualización interactiva en particular, traen nuevas técnicas para manipular datos" (Manovich, 2011: 148).

\section{La visualización de datos}

La visualización a partir de los datos (ena delante VD) pretende construir un conjunto gráfico, sintético o complementario, que destaque lo más significativo o los asuntos clave, que permitan entender, establecer agrupaciones, relaciones o tendencias estadísticas, que reduzcan al mínimo la entropía y facilite el obtener conclusiones o 
pruebas para su interpretación. Las denominadas minerías de datos usadas dentro del ámbito de los observatorios de vigilancia técnica o científica pueden aportar herramientas de mucha utilidad general (Sotolongo, Guzmán, Carrillo, 2002: 482).

Los datos son representaciones referentes a atributos o variables cuantificados, originados por la toma de muestras y su posterior transformación alfanumérica o visual (fenómenos que proporcionan puntos y no números o letras) de algún asunto más o menos significativo de un acontecimiento, acción o cosa.

A menudo su significación es debida a las sensaciones que se desenmascaran al acumularse o asociar tendencias estadísticas con dichos datos. Son muchas veces la base documental e informativa necesaria, con reducción de incertidumbres, para la toma de decisiones sobre contenidos muy diversos, desde el periodismo a la ciencia. Sin embargo, deben tenerse en cuenta en general algunos aspectos propios:

1. Los datos son registros codificados de observaciones de la realidad, son anotaciones convencionales sobre lo que se detecta en el estudio de los fenómenos que ocurren en ella.

2. En el origen, o están los datos fijados y cerrados, o bien se encuentran activos y sometidos a constante transformación o cambios; los primeros pueden ser históricos y los segundos sujetos a variaciones de la naturaleza o la realidad desafiante de cada momento que se vive.

3. La forma de obtener los datos no es uniforme, no siempre aparecen gracias a aparatos medidores de los fenómenos, aunque, en cambio, otras veces son medibles o estimables directamente.

4. Los aparatos con los que se miden variables no están exentos de defectos y pueden contener errores en sus lecturas o imputables a las personas que llevan a cabo su medición.

5. A menudo los datos son tomados de forma atributiva y no por variables medibles, por lo que no se pueden considerar con la misma precisión a unos que a otros.

6. Los datos pueden ser el resultado del análisis de muestras seleccionadas y limitadas no necesariamente de poblaciones enteras, fenómenos u objetos, como sucede en estadísticas y sondeos. 
7. Los datos pueden tener su origen en la medición o son resultado de transformaciones que cambian su magnitud, tales como los valores logarítmicos que transforman magnitudes geométricas en aritméticas, o todo tipo de traducciones/adaptaciones para que puedan explicarse en el contexto al que son dirigidos.

Las representaciones gráficas a partir de datos o VD se construyen con unidades gráficas elementales, líneas, puntos, áreas (superficies y volúmenes) con sus colores planos o bien con unidades gráficas complejas como las icónicas captadas (Ver Bertín, 1967) o de dibujo, polícromas o incoloras. Con la expansión de la informática a finales de los en los años 1980 se comenzó a diseñar visualizaciones comparativas en la prensa escrita para acompañar, sustituir o implementar informaciones y así permitir que los contenidos escritos se centrasen en otros temas, o simplemente fueran mas eficaces en su objetivo de mejorar la comprensión de las informaciones, con un propósito complementario, en las noticias y reportajes. Con la llegada de la informática gráfica y la programación se presentaron nuevos modelos en las publicaciones de internet emulando a los que se utilizaban en buena parte de las ciencias físicas o estadísticas. Aunque esas representaciones no eran nuevas se aprovecharon todos los nuevos sistemas de avances tecnológicos del momento construyendo así ciertas clasificaciones basadas en la semiótica (Cordoba, Alatriste, 2012).

La llamada VD se ocupa de este tipo de procesos, se parte del principio de que las representaciones de datos generan descripciones y hasta incluso narraciones en algunos pocos casos. Éstas pueden simplificar, medir, comparar, explorar, descubrir, explicar parcialmente cosas, etc. transformando los datos en conocimientos clave. Se pueden entender como productos que son expresiones que se refieren a las infografías cuya fuente principal son datos diversos y fidedignos. Se elaboran para cubrir necesidades de tipo comparativo o de visualización de ideas a partir de la elaboración de grafismo a partir de datos.

Algunos momentos de la historia de la visualización merecen la pena ser recordados: 
- 1637 René Descartes en su libro “Géométrie" presentó las conocidas coordenadas cartesianas que tanto han representado en la ciencia y la técnica.

- 1644 Michael F. Van Langren destapó imprecisiones en las mediciones longitudinales terrestres por medio de la observación y mapeo de la luna. 1765 Joseph Priestley primero que utilizó la línea de tiempo.

- William Playfair (1759-1823) ideó gráficos circulares, barras y series temporales.

- 1858, Florence Nightingale elaboró gráficos de comparación entre las causas de mortalidad en los hospitales de campaña durante la Guerra de Crimea y los de Inglaterra.

- 1869 C. J. Minard elaboró un conocido gráfico de pérdida de soldados en la invasión y retirada del ejercito de Napoleón en Rusia 1812-1813.

- 1911 Henry L. Gantt planificó los tiempos industriales de forma sistemática por medio del denominado diagrama de Gantt.

- 1913: el diagrama de Herzprung-Rusell, para el estudio de la luminosidad y temperatura de color de las estrellas.

- 1924 Otto Neurath fue un sociólogo que creó ISOTYPE, que es un sistema de de representaciones icónicas para complemento de los textos.

- 1991, Tim Berners-Lee inventó el sistema de telaraña (WWW).

Durante las últimas dos décadas se han sucedido importantes transformaciones en los campos de la visualización, infografía, organización de información, psicología cognitiva, lingüística y otros campos de la ciencia antes no relacionados. La aparición del ordenador y especialmente de Internet y la web, han transformado el escenario.

Algunos modelos han ido empleándose en diversos ámbitos con nombres diversos como mappings, treemaps, impactopias, jardines, sparklines, ciudades digitales, etc. (Ver Dürsteler, 2003: 103) ${ }^{48}$.

\footnotetext{
${ }^{48}$ Datos tomados parcialmente de la web http:/ / infovis.net/ el día 24-4-2014, de Juan Carlos Dürsteler (Ampliación digital del libro referenciado como Dürsteler, 2003, en la bibliografía).
} 
En la actualidad destacan por sus propuestas algunos autores de como Shneiderman con sus mapas de árbol (treemaps) para consulta dinámicas de análisis en series temporales y multidimensionales de datos extraídos incluso de redes sociales. Mackinlay que empleó en sus diseños el concepto de "Information Visualization" en 1999 o Munzner que estudió los fundamentos de los gráficos a finales de la primera década del siglo XXI (Card, Mackinlay, Shneiderman, 1999).

La visualización es un recurso muy utilizado no solo en los medios sino también en instituciones públicas y privadas que se valen de estas representaciones para facilitar importantes conocimientos a unos ciudadanos bastante heterogéneos the important information from more than a million measurements is immediately available. Visualization allows the perception of emergent propertys that were not anticipated (Ware, 2004: 3).

En el mundo del periodismo podemos nombrar a algunos de los profesionales que han aplicado representaciones parciales a partir de datos, como los históricos Alejandro Malofiej o Peter Sullivan y algunos de los actuales profesionales del periodismo como Amanda Cox, Mario Tascón, Jordi Català, Jeff Goertzen, Rafael Hörh, Chiqui Esteban, Tomás Alhambra, Xaquín González, Juan Pablo Noriega, Jaume Serra (Serra, 2010), Alberto Cairo, etc. Todos ellos han elaborado buenas propuestas de visualización en sus respectivos medios, con o sin la informática como apoyo, algunos de ellos con mas de treinta años de experiencia.

\section{Método}

La taxonomía permite ver el estado de una materia y también proponer los modelos útiles dada una determinada situación comunicativa. Existen intentos de clasificación, pero en el caso del periodismo, no existe, hasta el momento, una clasificación actualizada sobre las visualizaciones de datos. Por ello hemos decidido revisar la caracterización de diversas categorías que se han ido configurando hasta la fecha, con el asesoramiento de algunos de los mencionados profesionales, en el párrafo precedente. 
Se han desarrollado modelos diversos con soluciones muy dispares respecto a la obtención de contenidos gracias a los datos. Tradicionalmente se han creado diversos tipos de propuestas gráficas, como ejemplo basta con ver las representaciones de Bertin en Semiologie grafique u otras anteriores, incluso sin las nuevas herramientas del software pero también los tipos de datos por taxonomía también (Shneiderman, Plaisant, 2009: capítulo 14).

Sin embargo, hay cambios procedimentales motivados por la tecnología, tipos y niveles de información derivados de la reciente organización informática de las infraestructuras y superestructuras que han derivado en el progreso, como consecuencia de un cambio de enfoque en el ámbito de las relaciones públicas de las asociaciones e instituciones, que están nutriendo a las redacciones de datos, que no tienen representaciones fáciles o utilidad claramente comunicativa.

En la observación de más de 500 visualizaciones de datos en estos últimos años, doscientas de ellas impresas, siempre hemos intentando establecer nuevas tipologías de modelos que fueran distintos, pero no hemos hallado más que unos pocos ejemplos que son realmente diferentes entre sí, aunque es bien cierto que un mismo modelo se hace distinto en matices, al aplicarlo a otro conjunto conceptual, de datos, funcionalidad final o tecnología productora.

Esta clasificación está ordenada desde las clásicas presentaciones adaptadas de lo que apareció impreso en los medios periodísticos, a las mas modernas propuestas de webs ciberperiodísticas. Hemos distinguido los modelos tradicionales con variaciones puntuales motivadas, como son los modelos 1, 2, 3 y 4, de los claramente distintos, que emplean instrumentos muy modernos como el 5, 6 y 7 . Por otro lado distinguimos los siete primeros modelos, entendidos como visualizaciones elementales, en los que se suelen hibridar (Manovich, 2013: 215) diversos grafismos elementales, combinados con mezclas de alguno de los otros siete tipos y a los que en general denominamos misceláneas, como en el modelo 8 , entendidas como varias visualizaciones presentadas conjuntamente en un modelo único y amplio. 
Dada la gran versatilidad que tienen las presentaciones cuando se estudia un contenido, no tiene sentido pretender modelos puros en cuestiones de comunicación. Quizá puede ser aconsejable la no incorporación de altas densidades informativas, como sugieren a menudo los diversos profesionales infógrafos en sus charlas.

El movimiento, las grandes tecnografías multimediáticas en tres o cuatro dimensiones, los documentos muy originales, los procedentes de altas investigaciones, los big data o los algoritmos más complejos, no son condiciones necesariamente prioritarias en el estudio tipológico, pues son cualidades elementales que todos los tipos pueden contener.

El objetivo central ha sido el de estudiar sistemáticamente los parámetros con el fin de conocer los prototipos válidos para predecir su uso en nuevos documentos. Lo hemos ampliado al ámbito de cualquier web cibeperiodística, pero únicamente se han buscado las que se entienden como visualizaciones de datos, incluyendo modelos diversos de este tipo, especialmente periodísticos, prescindiendo de las que tienen principalmente objetivos persuasivos, tecnográficos, ficticios o artísticos.

Hemos seleccionado una submuestra de las 100 visualizaciones de datos digitales mas representativas, a partir de multitud de observaciones realizadas desde 1990, con los primeros estudios presentados desde la aparición del ciberperiodismo, que han aportado detalles diferenciales, obteniendo un total de 8 tipos distintos con una cierta repetición según las propuestas formuladas en los medios que más las emplean, lo cual quiere decir que son las más utilizadas en estos tiempos en el ciberperiodismo. A este estudio debemos considerarlo como la medida de unos indicios abiertos a nuevas posibilidades, conforme la tecnología y sus otras ramas implicadas avancen en el desarrollo.

Aunque localizadas y revisadas con anticipación, todas las muestras presentadas han sido capturadas de 174nternet el día 10-4-2014 a partir de las 10 horas de la mañana aproximadamente. Se ha realizado una revisión de lo que se puede entender como VD, limitándolo al contexto de la época presente y a los prototipos generados en estos años en los 
modelos presentados en webs periodísticas de referencia "A sabiendas de que existe una convergencia técnico-comunicativa y una integración de los medios tradicionales con los nativos en Internet"' (Cebrián, 2009: 21).

\section{Tipos de visualización de datos}

La taxonomía general que hemos deducido al revisar las visualizaciones de datos básicamente está centrada en las repeticiones de modelos. De un conjunto de cien visualizaciones se puede decir que hemos hallado las siguientes agrupaciones en las que las hemos clasificado.

1. Visualización espacial: Es la comparación de espacios, confluencias de puntos, líneas o zonas coloreadas a partir de datos. Los registros y campos (continuos o a intervalos) de una base de datos pueden presentarse visualmente por medio de barras, tartas, círculos, "ríos temáticos", capas acumuladas, "telas de araña, "nubes" de puntos, iconos, dibujos, palabras, etc.

El sistema digital separa textos enlazando otros lenguajes, pero a veces acompañan complementariamente a informaciones $\mathrm{O}$ documentaciones presentadas con formas tipográficas en las noticias. Se pueden construir de muy diversas maneras y es la técnica de mayor empleo en visualizaciones de datos a partir de registros y datos variables o sus representaciones (tasas, porcentajes, valores logarítmicos, etc.). Se han encontrado 38 sobre 100, por lo que indicialmente son las mas empleadas y a menudo las menos originales (ver figura 1).

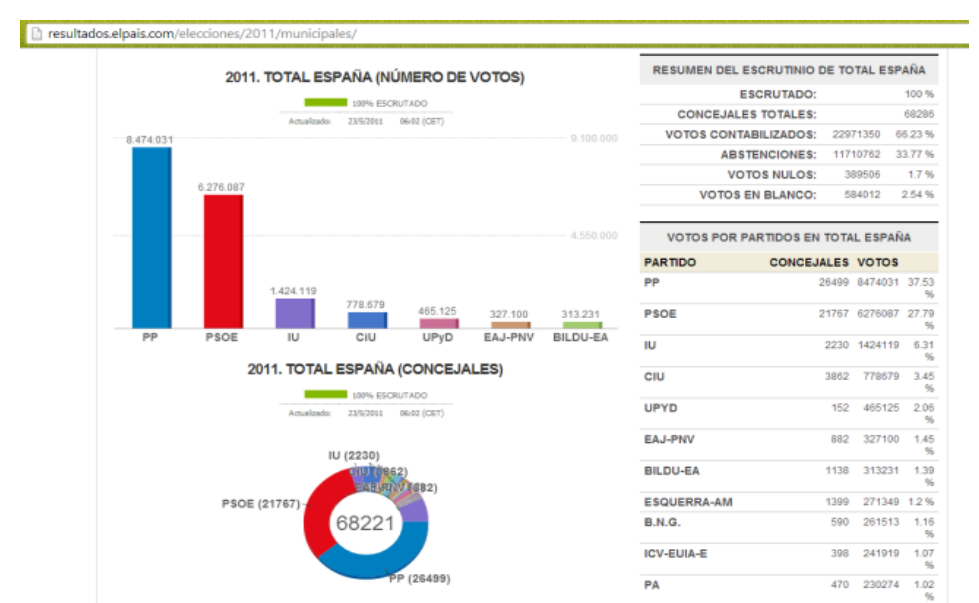

Figura 1. (Ver http:// resultados.elpais.com/ elecciones/2011/ municipales/). 
Los resultados cruzados de diversas variables, disparos, votos emitidos, etc. pueden configurar nubes de puntos, líneas, superficies circulares, manchas, o cambios de color que permiten denotar influencias en un determinado sector por comparación con otros, formando conjuntos de densidad o cromatismo variables relacionados con la frecuencia de los datos, etc. (ver figura 2).

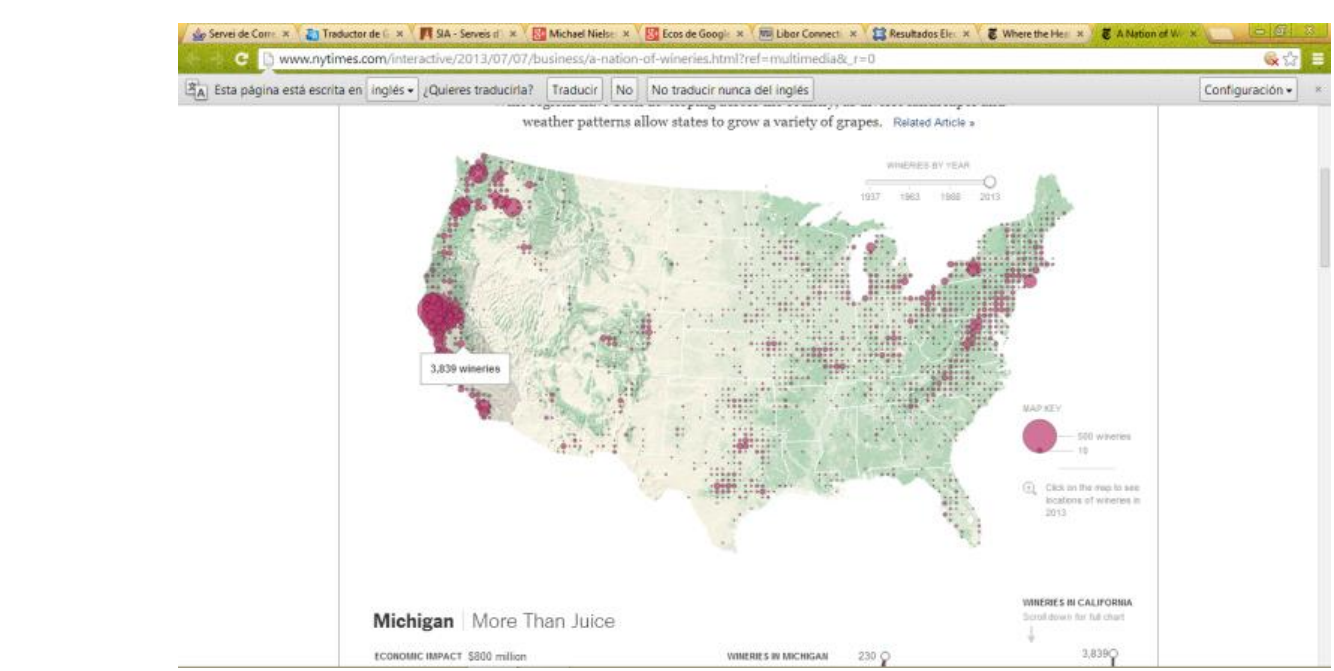

Figura 2. (Ver bttp:/ / wnw.nytimes.com/interactive/2013/07/07/business/a-nation-ofwineries. html? ref $=$ multimediae $r=0$ ).

En el ámbito deportivo con efectos en 4 dimensiones incluyendo vuelos de cámara sobre los objetos (ver figura 3). Son muy utilizadas las zonas de influencia coloreadas y explicadas mediante leyendas relativas a la actividad por equipos o jugadores en un encuentro deportivo (ver figura 4).

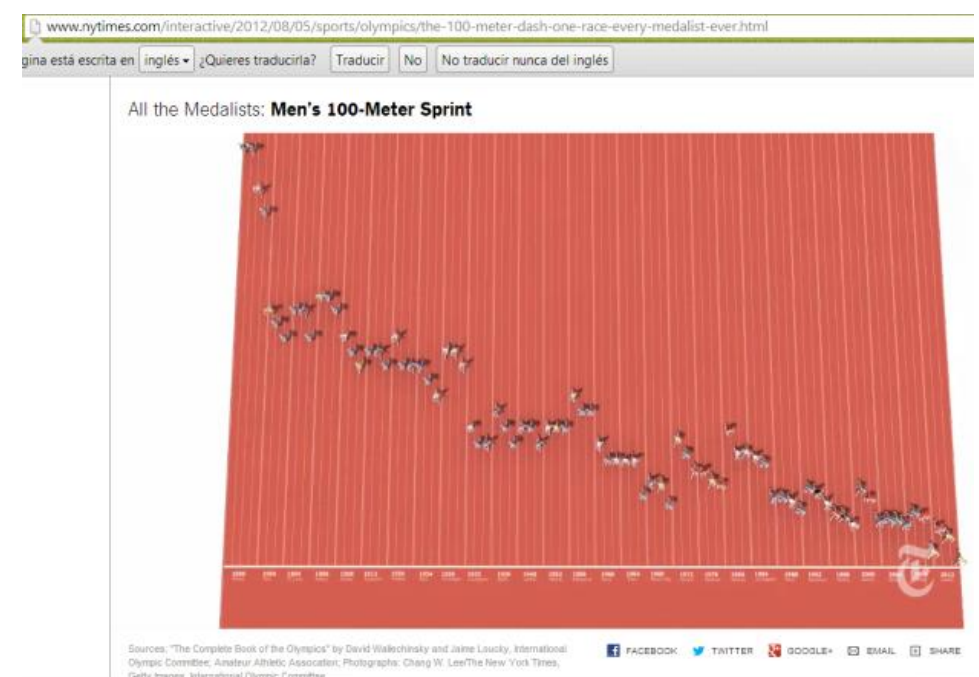

Figura 3. (Ver http:// wmw. nytimes.com/interactive/2012/08/05/sports/olympics/the100-meter-dash-one-race-every-medalist-ever.htmL). 


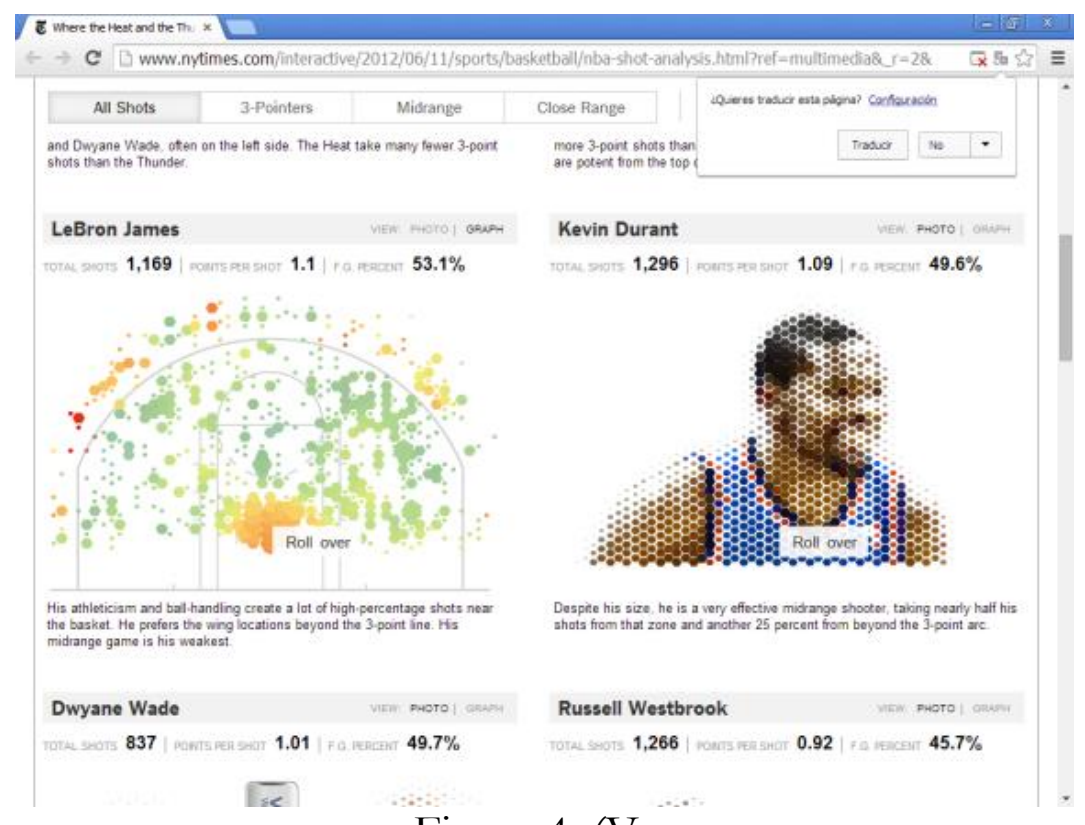

Figura 4. (Ver

bttp:// www.nytimes.com/interactive/2012/06/11/sports/basketball/ nba-shotanalysis. html? $r e f=$ multimediaes $r=0$ ).

2. Visualización tabular: Son estudios de propiedades registrales, interrelaciones comparadas, relaciones entre registros o campos, etc. Las tablas se absorben mediante nuestro sistema verbal, mientras que las gráficas nos llegan a través del visual (Few: 2012: 155). Se enfrentar en tablas los elementos de la misma o distinta especie, comparándolos y relacionándolos por medio de fichas, líneas de relación, datos, etc. (ver figura 5).

Las características comparadas son muy empleadas en rivales deportivos, electorales o económicos. En ellas se suelen enfrentar datos diversos como edades, títulos, aspectos significativos o posiciones en el juego, etc. Hemos encontrado 15/100. Suelen acompañar de forma complementaria a las informaciones $O$ documentaciones presentadas con formas tipográficas.

Las tablas, por registros o unidades de contenido, organizadas con interactividad o sin ella, presentan multitud de objetos o seres con los que se puede dar la comparación de características entre ellos. (ver figura 5). 


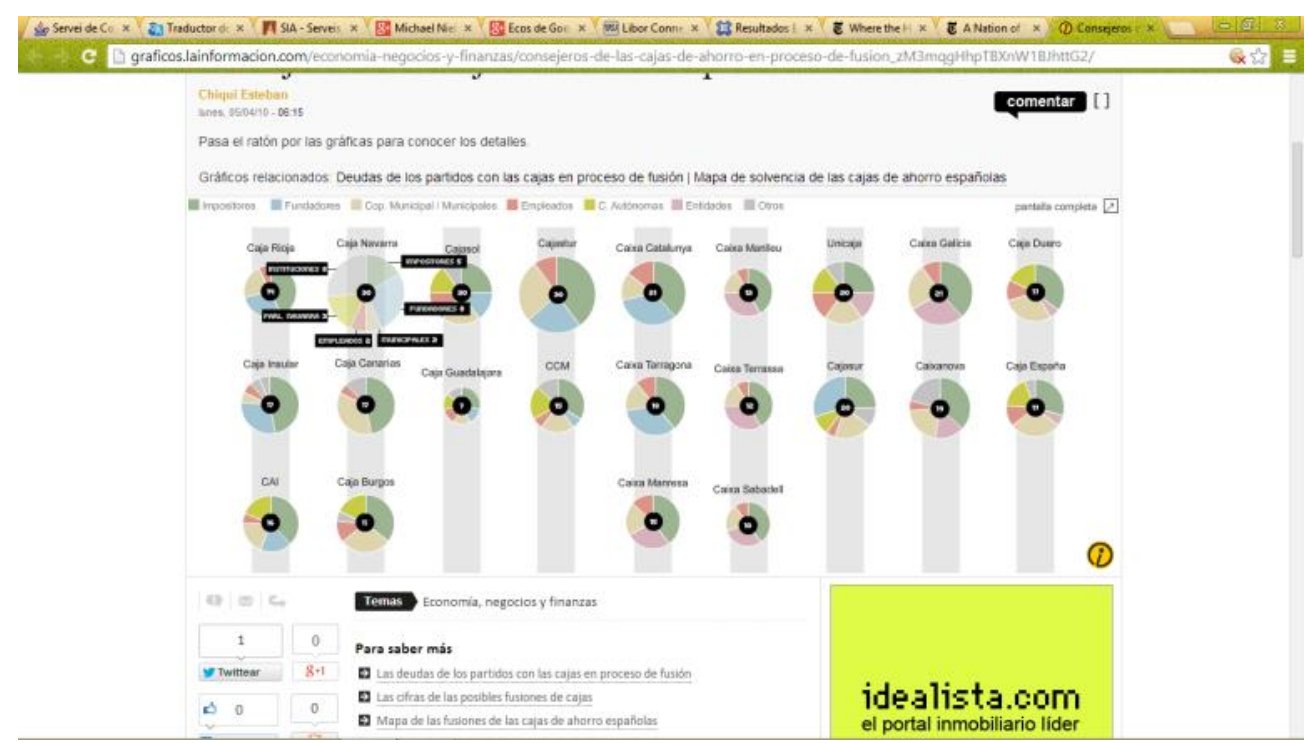

Figura 5. (Ver bttp:/ / graficos.lainformacion.com/economia-negocios-y-finanzas/consejerosde-las-cajas-de-ahorro-en-proceso-de-fusion zM3mqgHhpTBXnW1BJbttG2).

Como ejemplos podemos ver circuitos de competición motorizada, longitudes, curvas, dificultades, etc ${ }^{49}$. En deportes las tablas se presentan en distribución irregular por posiciones en el campo de juego con equipos, jugadores significativos, vehículos, circuitos, etc.

3. Visualización posicional: La posición en el espacio y el tipo de lenguaje empleado según la importancia que tengan puede denotar significación o relaciones de influencia. Cualquier variable individual o acumulada, puede acercarse o alejarse de ciertos lugares donde se encuentra los centros de significación y entonces se tiene una referencia individual con el conjunto, por ejemplo, en árboles genealógicos, de rivales, posiciones de políticos o jugadores, esquemas de empresa o funcionamiento, recintos, artefactos, diagramas de flujo o caudal, peligros, etc. Hemos encontrado 15/100 (ver figura 6).

\footnotetext{
${ }^{49}$ Hay multitud de propuestas tabulares diversas icónicas, alfanuméricas o mixtas.
} 


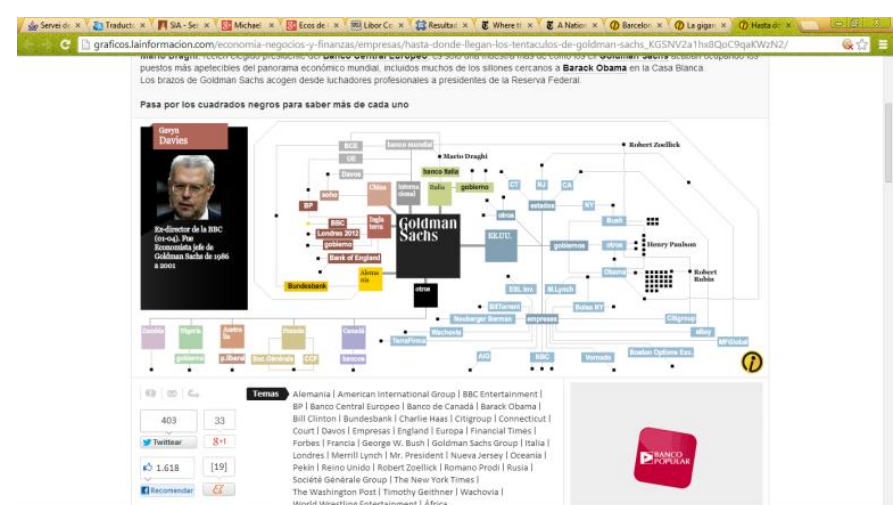

Figura 6. (Ver bttp:/ /graficos.lainformacion.com/economia-negocios-y-

finanzas/empresas/ hasta-donde-llegan-los-tentaculos-de-goldmansachs KGSNV2a1bx8OoC9qaKW $2 \mathrm{~N} 2 /$ ).

Tácticas, relaciones de influencia entre registros, personas fenómenos, componentes, etc. de las que hay múltiples modelos como los que se muestran en las figuras 7,8 y 9 .

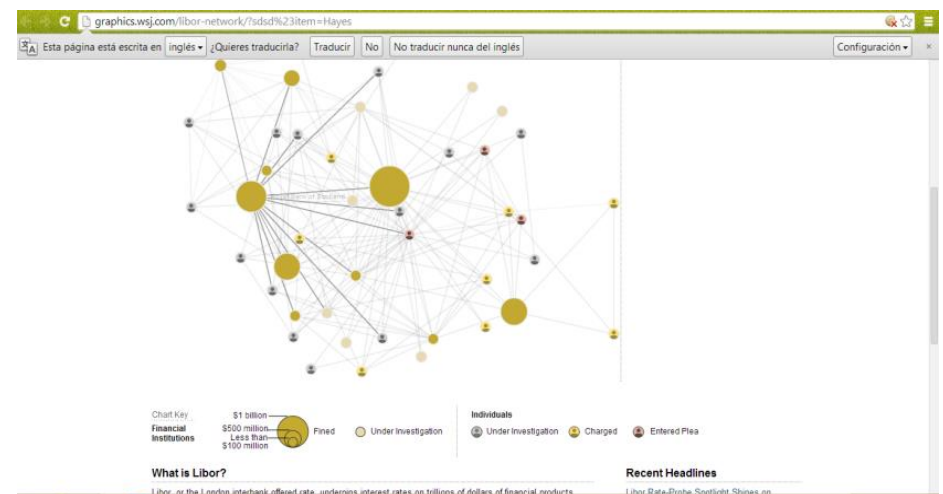

Figura 7. (Ver http://graphics.wsj.com/libor-network/?sdsd\#item=Hayes).

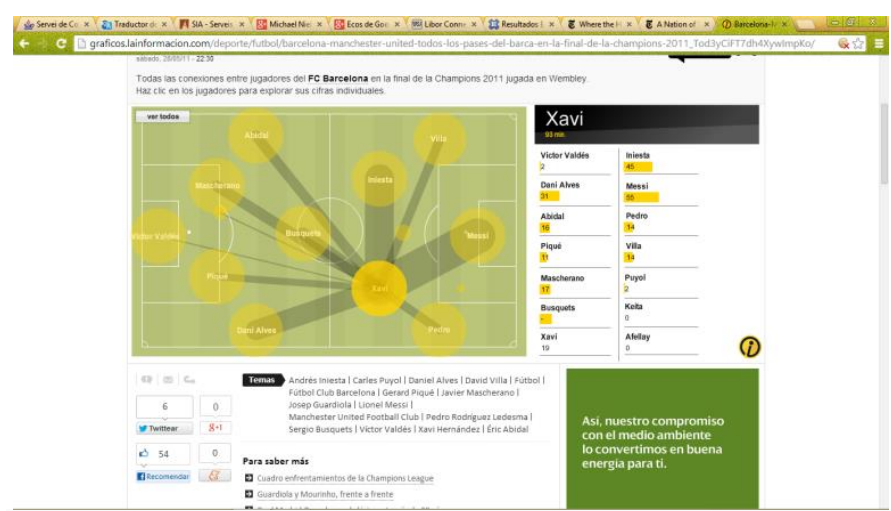

Figura 8. (Ver bttp:/ /graficos.lainformacion.com/deporte/futbol/ barcelona-manchesterunited-todos-los-pases-del-barca-en-la-final-de-la-champions2011 Tod3yCiFT7dh4XywImpKo). 


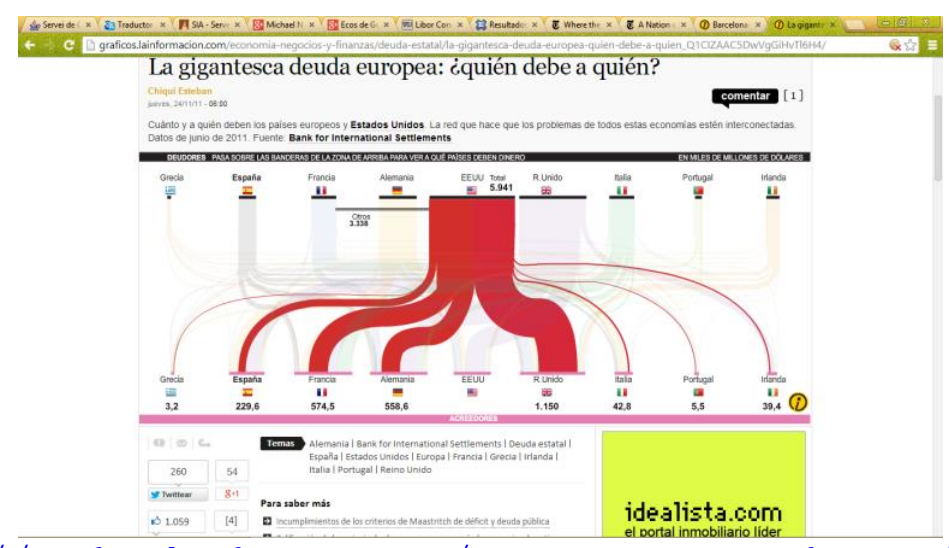

Figura 9. bttp://graficos.lainformacion.com/economia-negocios-y-finanzas/denda-estatal/lagigantesca-deuda-europea-quien-debe-a-quien Q1CIZAAC5DwVgGiHvTl6H4

Otros ejemplos pueden relacionar la posición temporal, la línea de tiempo o un dial con documentos:

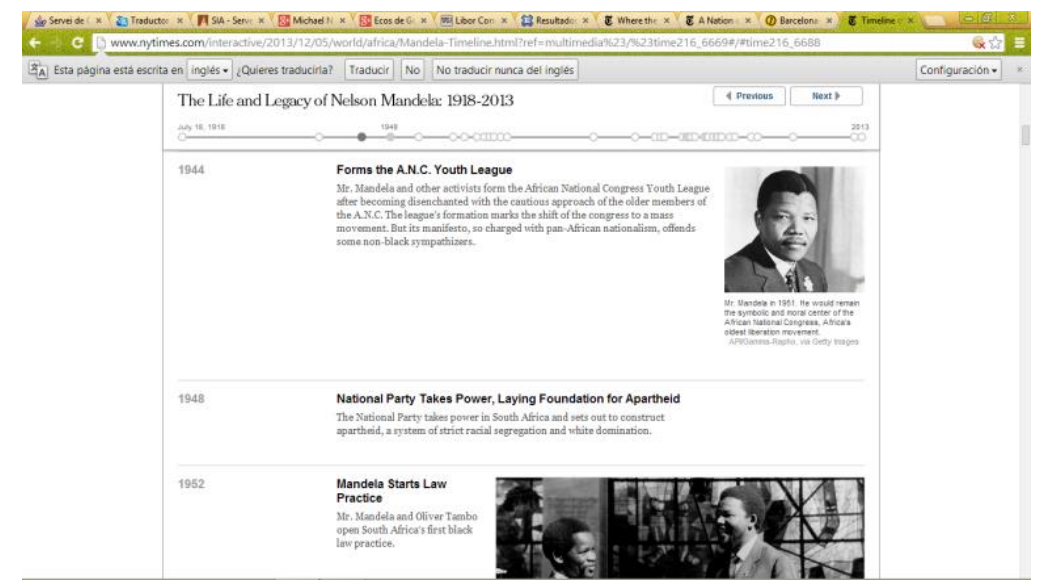

Figura 10. bttp:// mww.nytimes.com/interactive/2013/12/05/world/africa/MandelaTimeline.htmleref= multimedia\#/\#time216 6669.

Suelen normalmente acompañar a las informaciones o documentaciones presentadas con formas tipográficas, salvo en presentaciones interactivas en las que el esquema tiene en alguna de sus partes funciones de botón irregular que da pie a diversos documentos. En estos casos el esquema se presenta como si fuera el sumario de entrada.

4. Visualización topográfica: La representación por medio de territorios (mapas, planos, recintos o microplanos) puede o no tener objetivos ubicativos y también puede ser un soporte para la distribución de datos o figuras, con diversas propiedades multiescalares, anamórficas, multicolores, interactivas, etc. El grado de 
protagonismo del territorio marca la diferencia ya que a menudo aparecen formando parte del resto de modelos de visualización como unidades gráficas. Se han encontrado 12 sobre 100. También es corriente que en su soporte figure un mapa o plano de la zona que se estudia.

La más clásica de las VD topográficas es la que denominamos mapa del tiempo que contiene líneas isomorfas o isotrópicas sobre el terreno que informan de las variaciones climáticas. Suele ser habitual en los medios impresos y cibermedios desde que apareció por primera vez en The Times el día 1 de abril de 1875 (Ver figura 11).

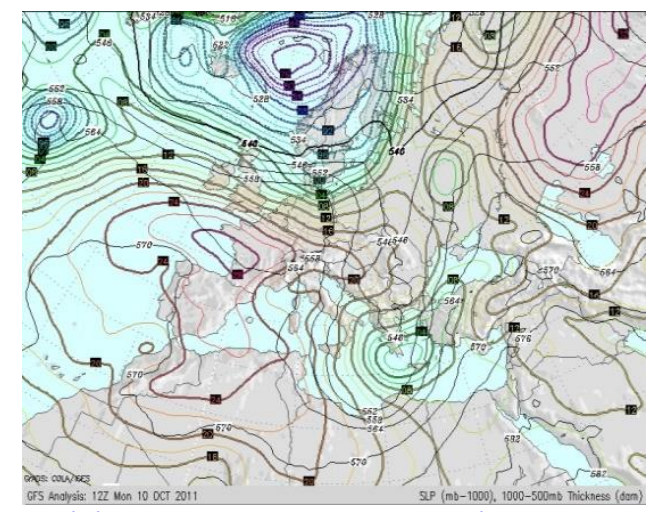

Figura 11. http://blogs.20minutos.es/emilio-rey-capturandotemperie/files/2011/10/pres.jpg

En la década de los años 1980, con la llegada de los ordenadores Macintosh, aparecieron en The Washington Post, Usa Today, etc. nuevos mapas del tiempo que aún hoy sirven de referencia en diversos diarios y medios digitales.

Dentro de los territorios tiene importancia la escala y así podemos hablar de mapas, planos, recintos y microplanos, todos ellos con sus propias peculiaridades de representación y también multiescalarmente por medio de zooms o solapamientos. Aunque no se han encontrado modelos, también se incluirían por su importancia topográfica los espacios en vertical como los puntos kilométricos asociados a las pendientes del relieve, las rutas de alzada de la carretera (mapas ciclistas), niveles de las plantas de un edificio, etc.

Los llamados mapas anamórficos pretenden simular distancias, pero la unidad de medida no necesariamente es la métrica (ver figura 12). 


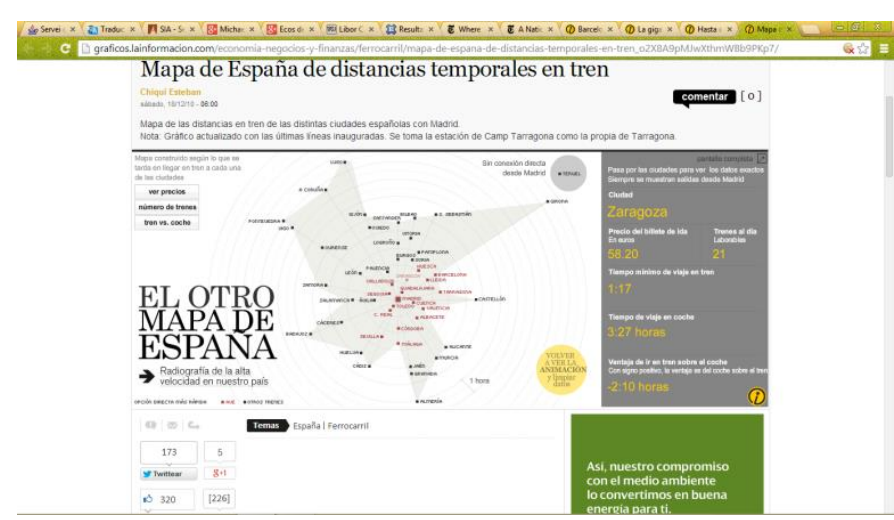

Figura 12. (bttp://graficos.lainformacion.com/economia-negocios-yfinanzas/ferrocarril/ mapa-de-espana-de-distancias-temporales-entren o2X8A9pMJwXthmWB69PKp7).

Los territorios prácticamente siempre tienen objetivos ubicativos y de ahí que hayamos considerado la opción tipológica en el estudio de la VD. Es muy corriente asociar cualquier territorio a rutas, límites fronterizos, distribuciones o cualquier reología o conexión, como puede ser cuando se presenta para la distribución sumarial de contenidos por medio de puntos activos, comparaciones de características, etc. (ver figuras 13 y 14) ${ }^{50}$. Los mapas interactivos también se suelen emplearse como soporte, puesto que se le asocian funciones de botón irregular para el reparto a diversos documentos.

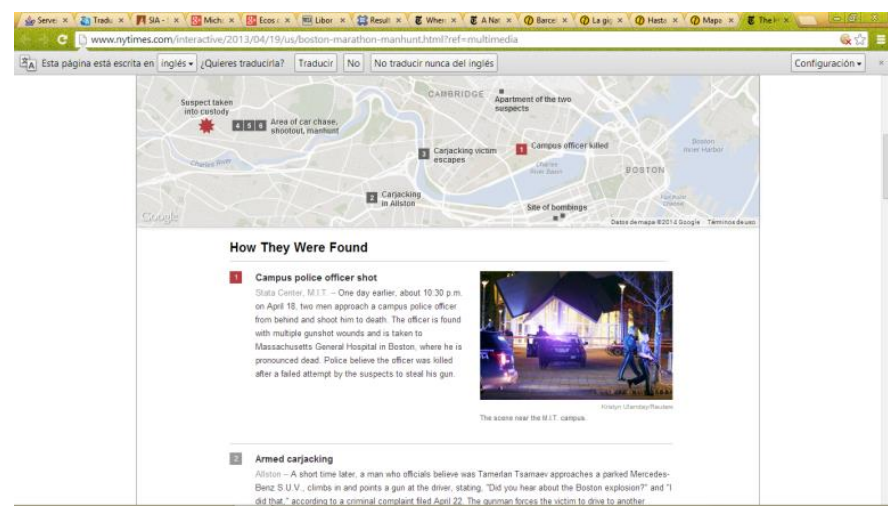

Figura 13. (bttp:// wmw.nytimes.com/interactive/2013/04/19/us/boston-marathonmanbunt.btml?ref=-multimedia).

${ }^{50}$ Los mapas con distribución por regiones, de monumentos, estadios de fútbol, gráficos, fichas de datos, etc. se pueden entender como tablas o visualizaciones ubicativas, según la intención del interpretante y la importancia de lo distribuido. 


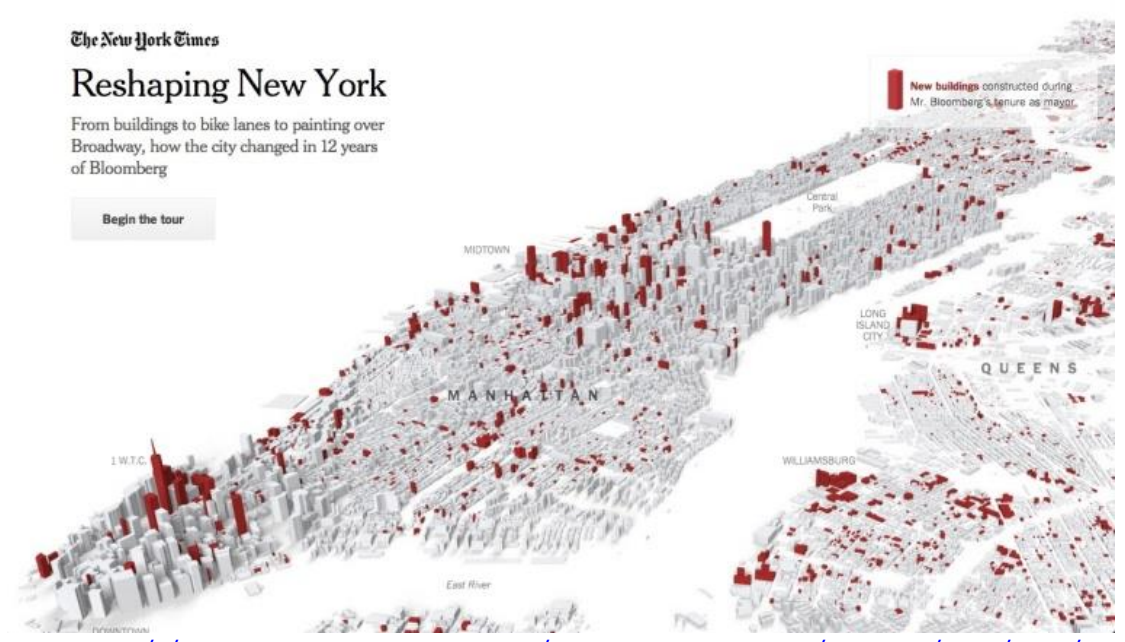

Figura 14. http://www.nytimes.com/newsgraphics/2013/08/18/reshapingnew-york/

5. Visualización teledinámica: Por la importancia que tienen hemos distinguido las presentaciones dinámicas cambiantes, procesos automatismos, etc. Pueden ser de varios tipos: Representaciones dinámicas que cambian a partir de los datos de coordenadas espaciales, como los asociados a vehículos de transporte en competiciones interoceánicas o interterritoriales; los que utilizan los goles o resultados deportivos, etc. y los que se dibujan a partir de los datos de centros de cálculo en las campañas electorales. Hemos encontrado 7/100.

La recepción de datos a XML-Flash o html 5, permiten la actualización de grafismo programado, como ocurre en los prototipos de los recuentos al final de las jornadas electorales, presentados en tiempo real en portada de muchos cibermedios generalistas, cuando van apareciendo los resultados de la votación. En este caso el mapa no tiene un sentido ubicativo sino distributivo. Las presentaciones espaciales tienen la importantísima cualidad visual de reflejar el momento en que se están produciendo unos aconteciminentos (ver figuras 15 y 16).

Pueden ser complementos documentales o se presentarse aislada y separadamente de los contextos informativos o documentales. Resulta de sumo interés ver el seguimiento por geolocalización, de una competición en tiempo real, como se muestra en algunas pruebas de navegación oceánica, en las visualizaciones multimedia de la Barcelona Word Race de 2010-2011, solamente visibles mientras dura la competición (Valero 2012: 108). 


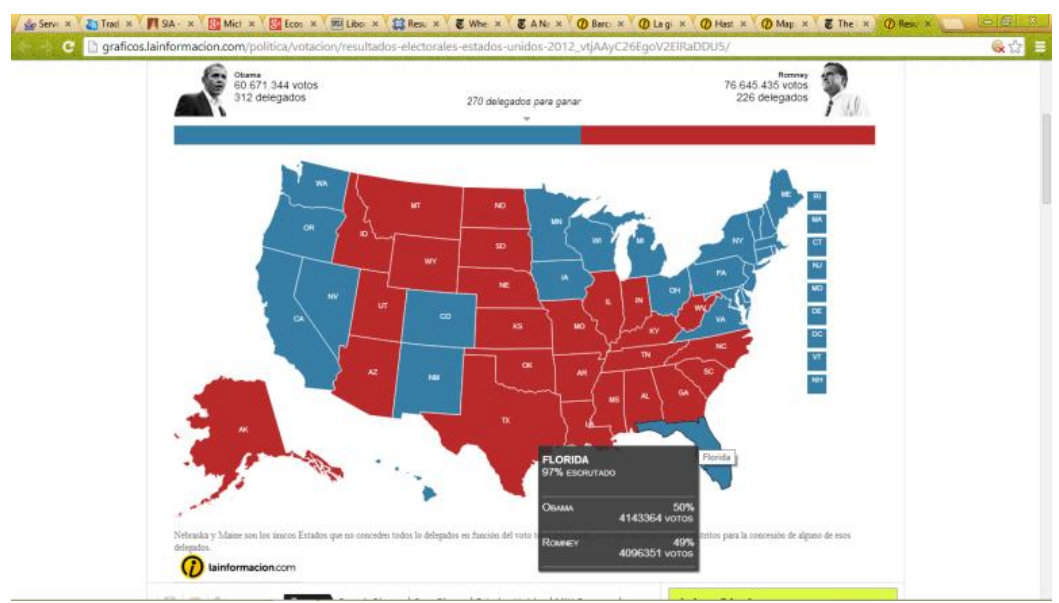

Figura 15. (bttp://graficos.lainformacion.com/politica/votacion/ resultados-electoralesestados-unidos-2012vtjAAyC26EgoV2E/RaDDU5).

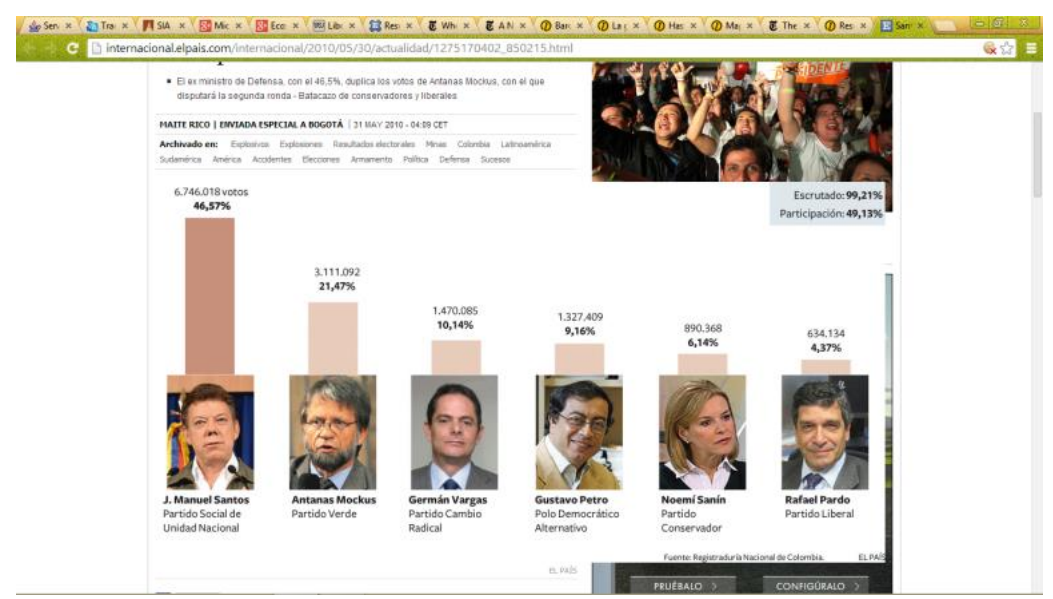

Figura 16.

(http://internacional.elpais.com/internacional/2010/05/30/actualidad/127517 $\underline{0402850215 . h t m l}$ ).

6. Visualización de arrastre interactivo (Drag and drop): Se puede considerar la más interactiva en general. Se presenta con funciones de arrastre o elección por parte del intérprete que activa, cálculos o proposiciones en diagramas de resolución, calculadoras, etc. Es necesaria la activación, algoritmos y datos introducidos en el documento para el cálculo, se presentan en ábacos de resolución de caminos críticos, datos calculados comparables, etc. Hemos encontrado 4/100.

Pueden ser de muchos tipos y su empleo es complejo. Un ejemplo de ellos puede ser un gráfico que asocie las elecciones del intérprete con los cálculos de coste de un equipo deportivo (ver figura 17). 


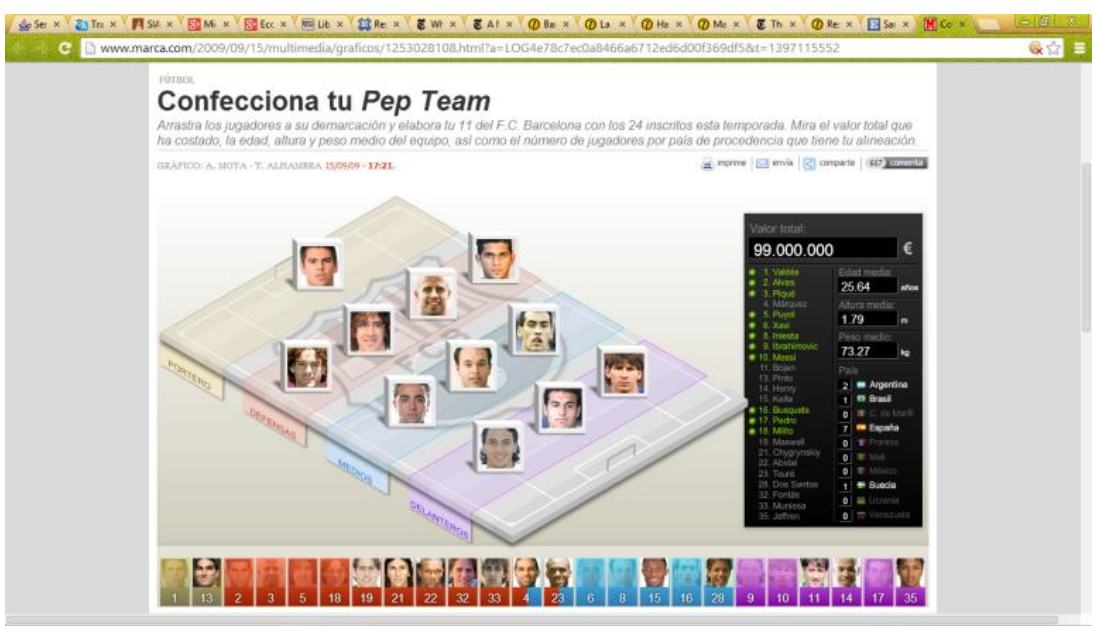

Figura 17.

(bttp:// wnw.marca.com/2009/09/15/ multimedia/graficos/1253028108.htmL).

En otros casos el deslizamiento se produce al comparar dos artefactos similares como en una comparación de sus detalles o un planeta y sus desplazamientos seguidos de cálculos o imágenes en determinados lugares (ver figura 18).

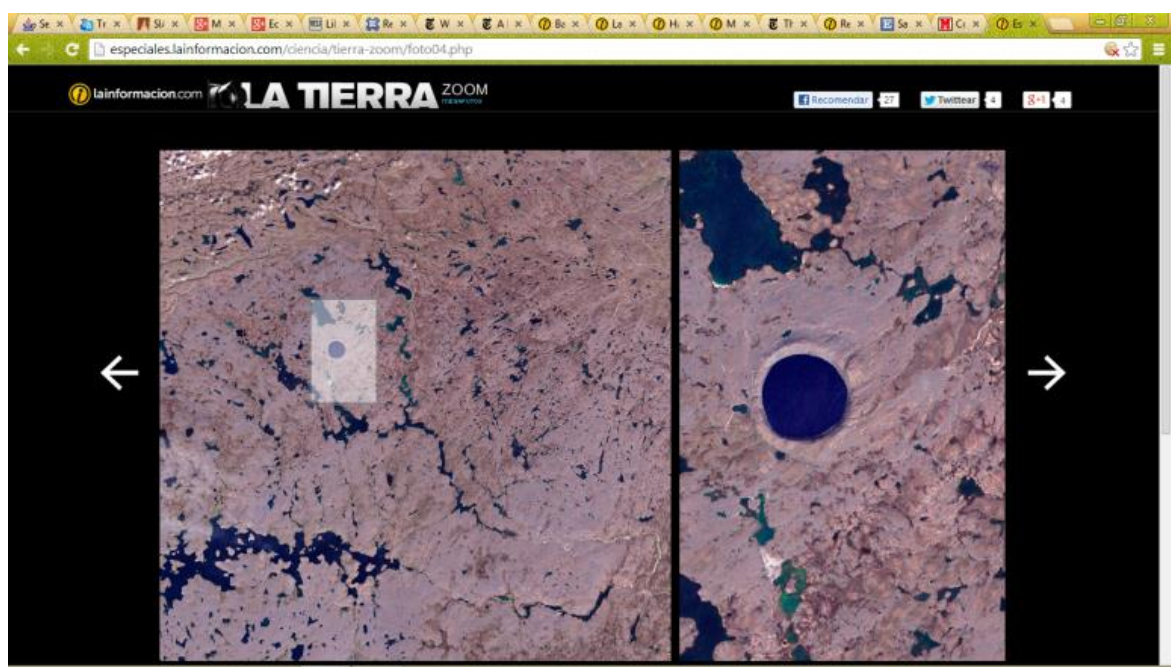

Figura 18. (bttp:/ especiales.lainformacion.com/ciencia/tierra-zoom/).

Dependiendo de los contenidos pueden o no acompañar a las informaciones o documentaciones presentadas con formas tipográficas y en este caso adoptan la forma de documento complementario.

7. Visualización de identificación aumentada: Son evoluciones gráficas de un proceso a partir de datos e imágenes fotográficas de alta 
resolución de escenas captadas y datos asociados, que aparecen al solicitarlas el intérprete. Hemos encontrado 3/100.

La naturaleza captable en forma icónica puede ser aumentada con datos asociados a ella ${ }^{51}$. Puede ser una visualización en la que se presentan fotografías normales o de alta resolución que permite identificar a las personas más relevantes en el lugar donde se encontraban por medio de globos o rótulos de identidad u otras características asociadas, en éstas los datos aparecen a partir del grafismo presentado (ver figura 19).
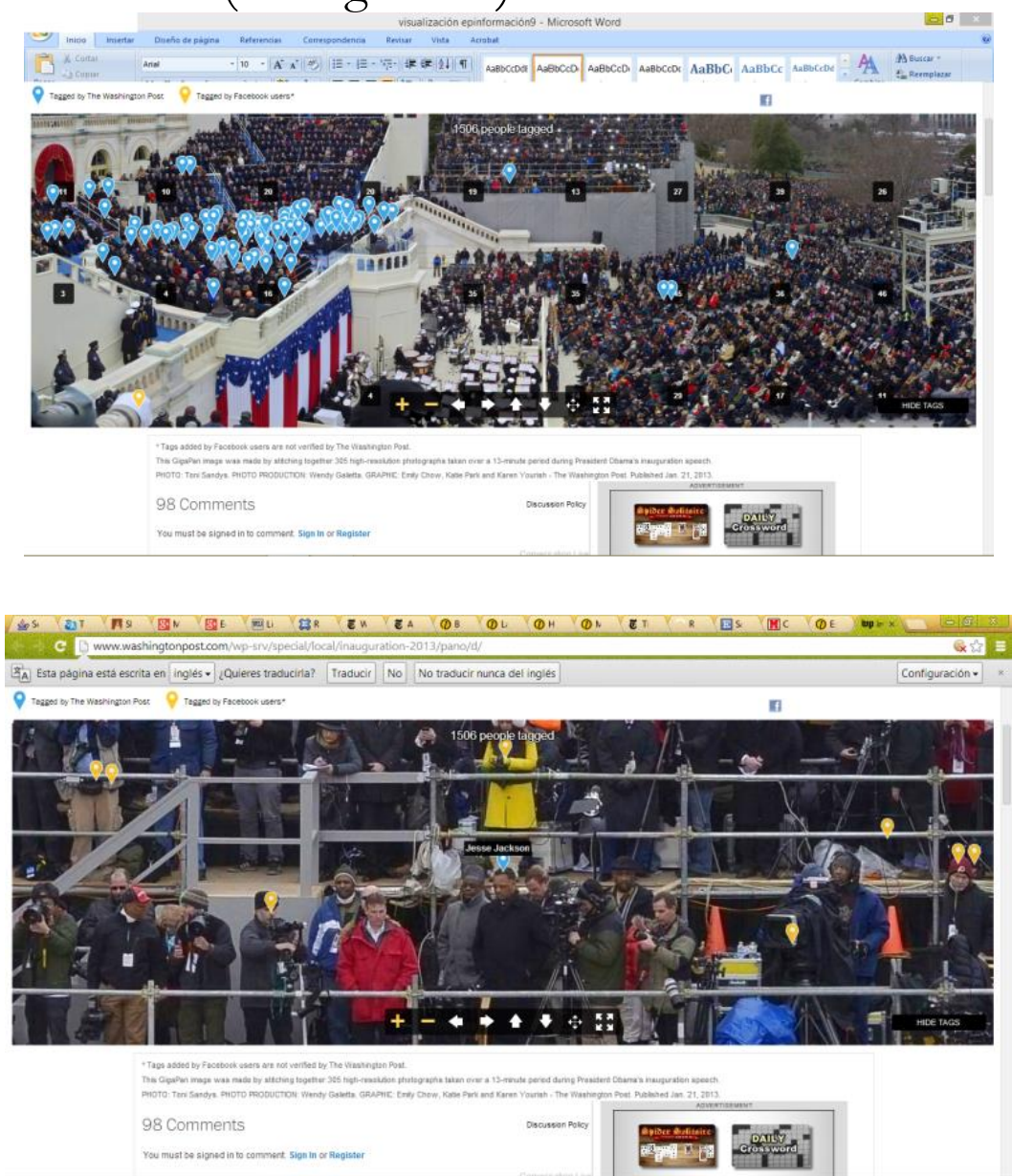

Figura 19. (Ver http:/ / wmw.washingtonpost.com/wp-srv/special/ local/ inauguration2013/pano/d/).

A veces el aumento de la dosis de identificación se consigue de forma no icónica ni alfanumérica sino por medio de sonidos u otros (ver figura 20).

${ }^{51}$ A menudo se entiende como realidad aumentada o realidad virtual, pero entendemos que la realidad puede ser inmaterial, poco captable y no se entiende como una representación. 


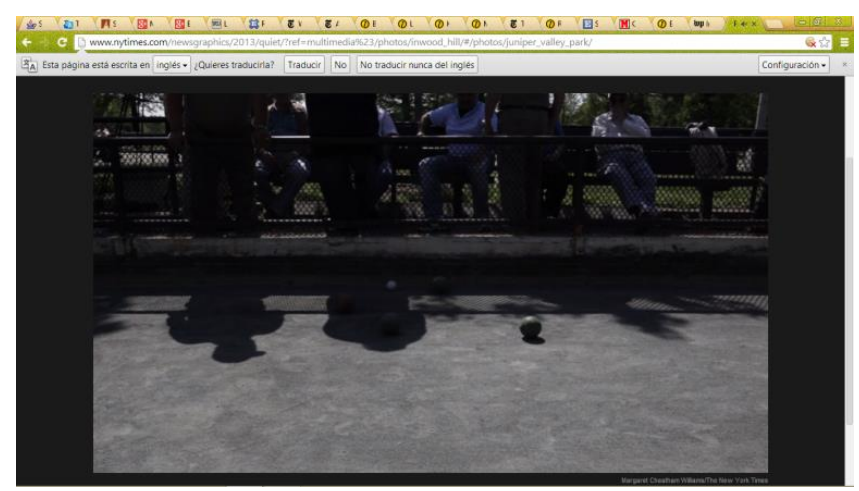

Figura 20.

(bttp:/ / www.nytimes.com/newsgraphics/2013/quiet/?ref=multimedia\#/photos/inwood b ill/).

Dependiendo de lo profundas, amplias o de iniciativas y temáticas particulares pueden o no acompañar a las informaciones $o$ documentaciones presentadas con formas tipográficas.

8. Miscelánea de varias visualizaciones: Son multitud de posibles representaciones conjuntas de gráficos, simultáneas o sucesivas, que se pueden presentar mezcladas plurimórficas y multipropuesta, como complementos, etc. ${ }^{52}$

Uno de los ejemplos, aunque no siendo periodísticos, pueden incorporarse como ejemplo, procede de la web de una asociación sin ánimo de lucro como Gapminder.org. Su principal documento titulado "Riqueza y salud de las naciones", está basado en conjuntos muy grandes de datos organizados en series de contenidos organizados fundamentalmente por países y años (ver figura 21).

\footnotetext{
${ }^{52}$ Por las matemáticas generales, a nivel de curiosidad en lo referente a la combinatoria sin repetición, deducimos que las posibles misceláneas son 21 cuando tenemos 7 modelos simples tomados de 2 en 2, 35 de 3 en 3, 35 de 4 en 4, 21 tipos tomados de 5 en 5 , etc. lo cual supone un conjunto muy amplio de propuestas en las que intervienen dos o mas propuestas.
} 


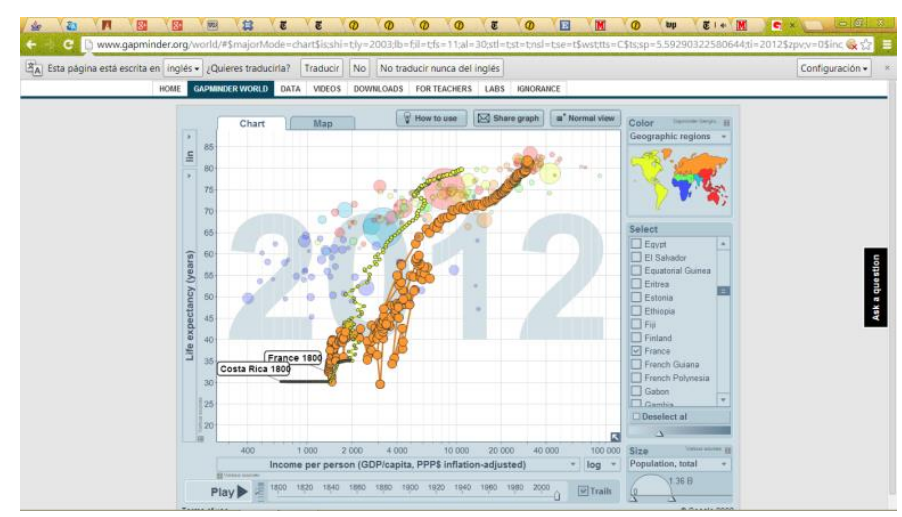

Figura 21. (http:// wow.gapminder.org/world/L).

Modelos miscelánicos hemos encontrado 6 sobre 100, pero se puede decir que dependiendo de lo profundas y amplias que sean las presentaciones con datos contienen mas o menos presentaciones. Todos los modelos pueden contener en alguna medida mezclas diversas. Unos datos se presentan con territorios, otros con gráficos diversos, etc. (Ver figura 22).

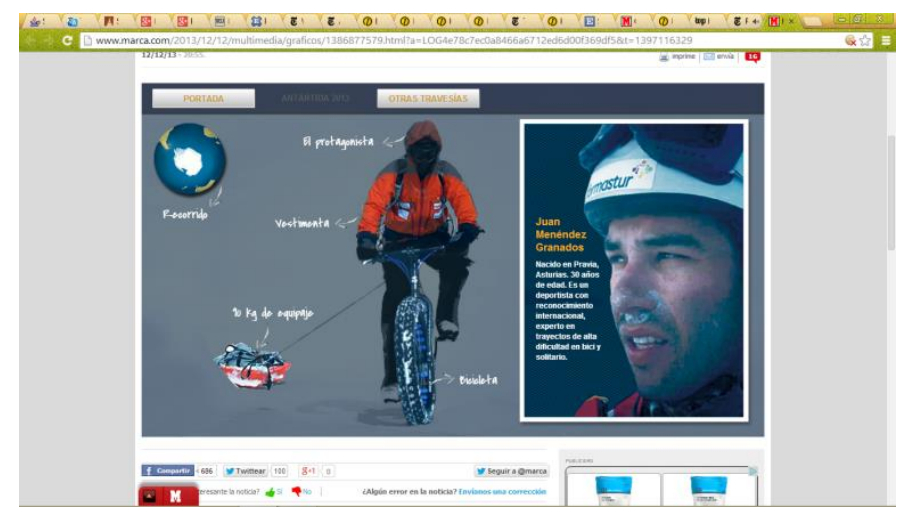

Figura 22.

(http:// wnw.marca.com/2013/12/12/ multimedia/graficos/1386877579.btml).

No suelen acompañar a las informaciones o documentaciones presentadas con formas tipográficas.

En resumen, hemos seleccionado un conjunto de 100 visualizaciones de datos con los siguientes resultados:

\begin{tabular}{|l|l|}
\hline Cantidad & Tipo \\
\hline 38 & Espacial \\
\hline 15 & Tabular \\
\hline 15 & Posicional \\
\hline 12 & Topográfica \\
\hline
\end{tabular}




\begin{tabular}{|l|l|}
\hline 7 & Teledinámica \\
\hline 6 & Miscelánea \\
\hline 4 & Drag and drop \\
\hline 3 & $\begin{array}{l}\text { Identificación } \\
\text { aumentada }\end{array}$ \\
\hline 100 & \\
\hline
\end{tabular}

Fuente propia.

\section{Conclusiones}

En ciberperiodismo, la noticia, el reportaje, etc. se suelen construir formas infográficas que incluyen la VD. El relato visual de un determinado contenido puede utilizar lenguajes multimedia capaces de sustituir los textos clásicos por textos más visuales que los tipográficos. Desde el inicio de los medios digitales se emplea el término infografía y, a pesar de la existencia de cierta polisemia y sinonimia, también se denominó así a los modelos que se configuran a partir de datos, si atendemos a la bibliografía, definiciones académicas y comentarios de buena parte de los profesionales de la comunicación que tradicionalmente las construyen.

Los datos son muy importantes, pero como fuentes documentales para la construcción de relatos visuales tienen muchas limitaciones pues no suelen presentar documentación para contar toda la historia de un asunto periodístico. Pueden generar nuevos conocimientos, pero no siempre se acierta a conseguir síntesis visuales útiles para que la interpretación sea comprensible y su uso genere prototipos, como circunstancialmente ocurre con los mapas del tiempo. Sin embargo, podemos afirmar que con los datos elementales se pueden estudiar asuntos de mayor relevancia presentados con formas metafóricas, abstractas, estadísticas, etc. representativas de conjuntos de cosas o seres.

Algunas de estas representaciones son antiquísimas y otras todavía están en el comienzo de su desarrollo. Su uso no se encuentra generalizado en los medios ni en las webs a causa de graves problemas aún no resueltos como la incomprensión de su utilidad, la secuencia de tiempo necesario para su desarrollo que choca con la inmediatez, y la necesidad de costoso y numeroso personal, altamente especializado, 
que encarece la producción y por tanto únicamente unos pocos medios las utilizan y son referencia, con personal preparado y ocupado específicamente, dentro del departamento infográfico.

Las VD tienen algunas características propias, destacan los asuntos clave, puntuales o de refuerzo informativo o documental, busca resultados visuales llamativos colaborando en las descripciones e interpretaciones de contexto y prueba confirmativa, no se encorsetan estructuralmente en relatos periodísticos clásicos, suelen presentarse como piezas discontinuas accesibles de temas o servicios concretos, con contenidos directos. Se emplean para proporcionar respuestas a necesidades puntuales diversas complementarias a las informaciones o documentaciones, aunque a menudo están separadas de las mismas.

La mayor parte de las VD encontradas se presentan principalmente con propósitos comparativos de diversos tipos: frecuencias diversas comparadas como representaciones espaciales de distancias, votos, tiempos, influencias, interrelaciones, características, posiciones, ubicaciones, variaciones de variables en el espacio o el tiempo, cálculos según interacción, identificaciones posicionales de características, elaboraciones estadísticas, resultados algorítmicos de cierta precisión que denotan valores significativos de interés variable, etc.

Aportan muchísima utilidad social, profundidad y realidad si se apoyan en datos correctamente tomados de cualquier clase de fenómeno o infraestructura. En este contexto se suelen presentar conjuntos cerrados en contenidos deportivos, políticos, económicos y de servicios que son terrenos abonados dentro de los medios.

No es muy normal ver figuraciones muy icónicas, aunque puntualmente pueden aparecer fotografías, vídeos e incluso sonidos. Las más comunes son planas en 2 dimensiones, no se suelen dibujar a mano alzada y pueden contener capas solapadas, mezclas o hibridaciones de grafismos.

La VD no es necesariamente digital, interactiva, telemática, 3 o 4 dimensiones, en movimiento o de grandes fórmulas. La interactividad apenas se ha empleado salvo en las situaciones en que se debe decidir entre varias opciones, pueden ser interactivas para la segunda lectura de ampliación o el cambio de campos variables o registros en un 
determinado desarrollo con múltiples enfoques. Suelen presentarse de lo general a lo particular o viceversa, ofreciendo nuevos horizontes de indagación para los intérpretes.

Se aprecia un cierto interés por este tipo de presentaciones si su lectura es fácil. Los medios las potencian por la rapidez de elaboración y el poco coste cuando se reutiliza su programación informática para otros contenidos. Los mismos modelos pueden servir para diversos empleos con un coste fijo inicial, pero con muchas posibilidades de repetición cuando el contenido lo permite.

En definitiva, la tecnología incorpora nuevas representaciones a las que la sociedad se adapta y alfabetiza, al igual que lo hizo con visualizaciones predictivas propias de los mapas del tiempo. Cada vez hay más propuestas complejas de programa,r pero muy efectivas, elaboradas con formas y navegaciones de rápida aplicación y adaptación a contenidos diversos.

\section{Referencias bibliográficas}

Bertín, J. (1967): Sémiologie Graphique. Les diagrammes, les réseaux, les cartes. París: Gauthier-Villars.

Cairo, A. (2011): El Arte funcional. Infografía y visualización de información. Madrid: Alamut

Card, S. \& Mackinlay, J. \& Shneiderman (1999): Readings in Information Visualization: Using Vision to Think. ISBN 1-55860-533-9

Cebrián, M. (2009): “Comunicación interactiva en los cibermedios". Comunicar, 33, 15-24. http://dx.doi.org/10.3916/c33-2009-02-001

Córdoba, C. \& Alatriste, Y. (2009): "Hacia una taxonomía de investigación entre Visualización de Información y Diseño". No Solo Usabilidad. ISSN 1886-8592. http://www.nosolousabilidad.com/articulos/taxonomia visualiza cion.htm\#sthash.PdeMC87A.dpuf 
Dürsteler J.C. (2000-2012) "Visualización de información" en Infovis.net. Instituto de Educación Continua (IdEC) de la Universitat Pompeu Fabra. Barcelona: http://infovis.net/ . (Fecha de consulta 24-4-2014).

Dürsteler J.C. (2003): Visualización de información. Barcelona: Gestión 2000.

Few, S. (2004): Show me the numbers: Designing tables and graphs to enlighten. USA: Analytics Press. ISBN 0970601999

Manovich L. (2013): El software toma el mando. Barcelona: UOCpres.

Manovich, L. (2011): “O que é visualização?”. Estudos em Jornalismo e Mídia, Junho de 2011, Vol. 8, N¹, pp.(1146-172). http://dx.doi.org/10.5007/1984-6924.2011v8n1p146

Sánchez, X. (2007): “Arte visual en la escuela”. La Vanguardia, 12 octubre, http://www.caffereggio.net/2007/10/12/arte-visual-laescuela-xaro-sanchez-la-vanguardia/

Serra, J. (2010): Una paradoja dominical. Barcelona: Ediciones de La Vanguardia.

Shneiderman, B. \& Plaisant, C. (2009): Designing the User Interface: Strategies for Effective Human-Computer Interaction; Addison-Wesley, 1987. ISBN 0-321-26978-0

Sotolongo, G. \& Guzmán, M.V. \& Carrillo, H. (2002): 'ViBlioSOM: Visualización de información bibliométrica mediante el mapeo autoorganizado". Revista española de Documentación Cientifica, Vol 25, No 4. http://dx.doi.org/10.3989/redc.2002.v25.i4.281

Valero J.L. (2008): "La infografía digital en el ciberperiodismo", en Revista Latina de Comunicación Social, 63, página 492 a 504. La Laguna (Tenerife): Universidad de La Laguna, (Fecha de consulta 24-4-2014). http://www.ull.es/publicaciones/latina/08/42 79965 Bellaterra LJose Luis Valero.html. 
Valero J.L. (2012 b): Infografía digital. La visualización sintética. Barcelona: Bosch, ISBN: 978-84-9790-949-5.

Ware, C. (2004): Information Visualization: Perception for design. San Francisco: Morgan- Kauffman. ISBN 978-0-12-381464-7.

\section{Bibliografías relacionadas}

Bounegru, L., Gray, J. \& Chambers, L. (2012): The Data Journalism Handbook. Sebastopol (EEUU): O'Reilly

Crucianelli, S. (2008-2013): Herramientas digitales para periodistas. Austin (EEUU): Knightcenter.utexas.edu. Para descargar: https://knightcenter.utexas.edu/hdpp.pdf

Holmes, N. (2012): The Book of Everything: A visual guide to travel and the world. Lonely Planet

Jacobson, R. (ed) (2000): Information Design. Masachusetts: The MITPress. ISBN 978-0-262-60035-4

Krum, R. (2013): Cool Infographics: Effective Communication with Data Visualization and Design. Indianápolis: Willey. ISBN: 978-1-11858230-5

Lankow, J. (2012): Infographics the power of visual storytelling. Nueva Jersey: Willey. ISBN: 978-1-118-31404-3

Malamed, C. (2009): Visual languaje for designers (segunda edición). Singapur: Rockport Publishers, ISBN: 978-1-59253-741-9

Murray, S. (2012): La VD interactivos para la web. California: OReilly Media. ISBN978-1-449-33973-9

Shneiderman, B. (1980): Software Psychology: Human Factors in Computer and Information Systems; Little, Brown and Co. ISBN 0-87626-816-5

Shneiderman, B. (2002): Leonardo's Laptop: Human Needs and the New Computing Technologies. MIT Press. ISBN 0-262-69299-6 
Sidwell, N. (2011): Facts Are Sacred. The Power of Data. Londres: The Guardian Books

Steele, J. \& Iliinsky, N. (2010): Beautiful Visualization. Sebastopol (EEUU): O'Reilly Media. (Para descargar: http://itebooks.info/book/283/).

Suda, B. (2010): A Practical Guide to Designing with Data. Penarth (Gales): Mark Boulton Design. (Para descargar: http://www.cl.cam.ac.uk/ ml421/reading/DesigningWithData_s ingle.pdf).

Want, K. (2013): Infographics \& Data Visualizations. RIBA Publicaciones. ISBN 9881545099, 9789881545091

Wong, D. (2010): The W all Street Journal Guide to Information Graphics: The Dos and Don'ts of Presenting Data, Facts, and Figures. Nueva York: W W Norton \& Company Incorporated

Yau, N. (2011): Visualize This: The FlowingData Guide to Design, Visualization, and Statistics. Indianápolis: John Wiley \& So 


\title{
IVII
}

\section{Infografia para surdos. \\ Narrativas visuais que potencializam a apreensão de conteúdos}

\author{
Mariana Lapolli (๑). UFSC, Brasil \\ marilapolli@gmail.com \\ Tarcísio Vanzin (๑). Departamento de Engenharia do \\ Conhecimento. Centro Tecnológico da UFSC, Brasil \\ tvanzin@gmail.com
}

José Luis Valero Sancho (๑). Departamento de Comunicação Audiovisual e Publicidade. UAB, Espanha

\section{joseluis.valero@uab.cat}

Resumo. As narrativas visuais existem desde os primórdios da humanidade. Com os avanços tecnológicos, novos suportes surgiram, possibilitando novas formas de se contar uma história enfatizando, cada vez mais, seus aspetos visuais. Neste artigo são apresentados exemplos de narrativas visuais do setor jornalístico, ressaltando que estes recursos podem ser utilizados em outros setores, como o educativo, por exemplo. Neste contexto, aborda-se a infografia que, quando veiculada na web, ganha características que possibilitam a acessibilidade digital. Qualificada como aplicada e exploratória, esta pesquisa propõe a infografia como uma forma de narrativa visual capaz de potencializar a apreensão de conteúdos por pessoas surdas.

Palavras chave: Narrativas visuais, infografia, surdos 


\section{Introdução}

$\mathrm{H}$

Á MILHARES de anos o ser humano talhava nas paredes das cavernas suas histórias, deixando como legado para as gerações futuras narrativas visuais sobre seu modo de vida, sua cultura, sua religião, seu comportamento etc. Este desejo de se comunicar, difundindo suas histórias, resultou na criação de novos suportes ao longo dos anos. Realizando um salto no espaço e no tempo, este artigo aterrissa no contexto digital, em que as narrativas visuais ganharam características como a não linearidade, a multimodalidade, a hipertextualidade, a convergência, a instantaneidade, entre outras.

As diversas possibilidades oferecidas pelo meio digital favorecem sobremaneira a acessibilidade, que consiste em disponibilizar aos usuários com algum tipo de deficiência, informações que eles sejam capazes de acessar de maneira autônoma e com o mínimo de esforço, minimizando as diferenças para com as pessoas que não tem limitações de acesso e permitindo-lhes compartilharem o mesmo ambiente. Nesta pesquisa, será tratada a comunidade surda como um grupo de pessoas cujas necessidades comunicativas passam a ser atendidas com a utilização dos recursos disponíveis na web. Será difundido o conceito de que suas particularidades no ato comunicativo não devem ser tratadas como deficiência, mas sim como uma forma diferente de experimentar o mundo e adquirir conhecimentos.

Diversas pesquisas apontam que a aquisição de conhecimentos pelos surdos ocorre sobretudo pela via visual. Lapolli, Vanzin e Valero Sancho (2018) destacam outras vias que não somente o olhar para percepção do entorno. Nessa obra, os autores apresentam dados e abrem a discussão para as potencialidades do corpo da pessoa surda. As narrativas visuais surgem, neste contexto, como canais para percepção de um mundo representativo, trazendo a infografia como um recurso comunicativo capaz de permear o corpo de seus intérpretes. Abastecidos de narrativas providas de imagens associadas a textos curtos, esses indivíduos apreendem conteúdos de forma mais criativa, atrativa e lúdica.

Diante do exposto, esta pesquisa visa propor a infografia como uma forma de narrativa visual capaz de potencializar a apreensão de conteúdos pelos surdos. Trata-se de uma pesquisa aplicada, pois 
objetiva gerar conhecimentos para a aplicação prática e dirigidos à solução de problemas específicos (Silva, Menezes, 2005: 20). É também exploratória, uma vez que mira "proporcionar maior familiaridade com o problema, com vistas a torná-lo mais explícito ou a construir hipóteses" (Gil, 2008: 41).

\section{Narrativas visuais e as infografias}

Desde remotas civilizações que marcaram a evolução da humanidade, os registros mostram que as pessoas narram acontecimentos, contando sobre aquilo que observaram, participaram ou ouviram falar. Deste modo, a narrativa pode ser compreendida como uma forma de transmitir informações e gerar conhecimentos. Representam um sequência de acontecimentos que se conectam e são transmitidos numa história. É por meio das narrativas que os sujeitos tentam compreender e se impor no mundo como um agente ativo da dinâmica comunicacional" (Braga, Silva, 2010: 4).

Inicialmente, a oralidade e os gestos eram utilizados pelas sociedades para transmitirem suas narrativas que, mais tarde, surgiram em suportes onde a escrita passou a ser a protagonista. Com o avanço e a popularização das Tecnologias de Informação e Comunicação, novas maneiras de se narrar uma história foram estabelecidas.

'O cinema, o rádio, a televisão e o computador, entre outros meios de comunicação se proliferavam, servindo como suporte para as narrativas. Dependendo do suporte comunicacional adotado por uma narrativa, ela assume determinadas características. Essas características possuem diversos pontos em comum, pois cada novo meio que surge inspira-se no modelo de seu antecessor. [...] E assim, vários meios de comunicação serviram de fonte de aprendizado para a elaboração de narrativas daqueles que surgiam posteriormente. (Lapolli, 2014: 87-88)

As imagens ganharam cada vez mais destaque a medida que novos suportes passaram a ser utilizados. Nos veículos impressos, ilustrações e fotos ganharam lugar de destaque junto aos elementos verbais. No cinema, uniu-se poeticamente elementos narrativos sonoros e visuais embasados num roteiro pré-estabelecido. A televisão adotou os mesmos elementos do cinema, porém nem sempre favorecendo a experiência artística. As novas mídias reuniram elementos narrativos 
desses meios, abrindo diversas possibilidades de interação e participação do público que, em alguns casos, passou a ser coautor do trabalho. "Quando o autor expande a bistória para nela incluir múltiplas possibilidades, o leitor adquire um papel mais ativo" (Murray, 2003: 50).

Como exemplos de narrativas visuais na web, é possível enfatizar as galerias de fotos em sites de notícias. Mesmo que estas galerias estejam vinculadas ao texto, esse tipo de narrativa transmite informações de maneira autônoma para os intérpretes. No site da World Press Photo, uma organização independente sem fins lucrativos reconhecida por realizar anualmente a maior e mais prestigiada distinção de fotojornalismo do mundo, diversos exemplos de foto-reportagens são encontrados. Em 2018, o primeiro prêmio na categoria Innovative Storytelling foi para a matéria intitulada Finding Home (time.com/finding-home), publicada na revista Time, que conta a história do bebê recém-nascido, Heln, e sua família. Trata-se de refugiados sírios em busca de asilo na Europa.

Esta matéria constrói uma rede de significados. Suas imagens rompem com a linearidade dos códigos verbais, abrindo-se para diversas possibilidades de leituras. Além de textos, este recurso apresenta elementos visuais como fotos, vídeos, mapas e tipografias. Deste modo, o verbal e o visual interagem na produção de sentidos, conduzindo à processos reflexivos.

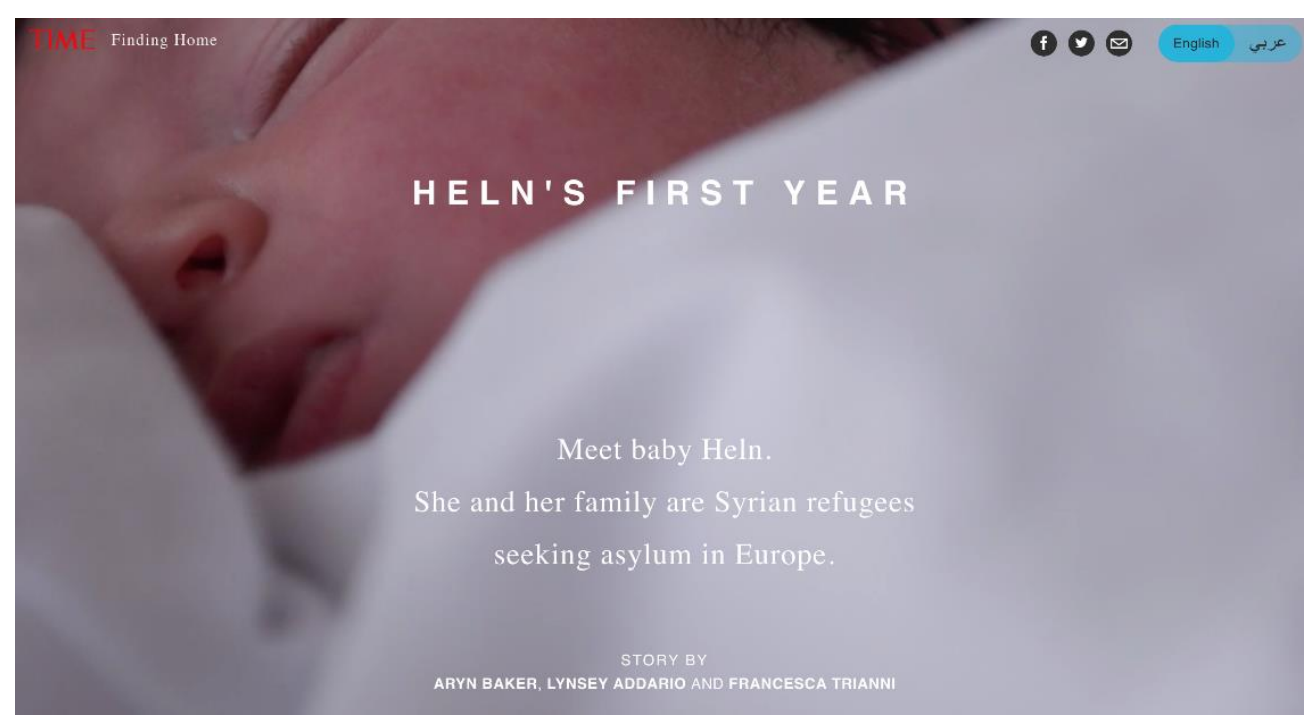

Figura 1: Página Inicial da foto-reportagem Finding Home. Fonte: http://time.com/finding-home 
Da mesma forma que as foto-reportagens utilizam o verbal e visual de maneira integrada no meio jornalístico, isto também ocorre com os infográficos, que ganharam destaque a partir da década de 1980 neste setor. $\mathrm{Na}$ década seguinte, nos anos 1990, as infografias na web se difundiram, utilizando recursos como os links, os vídeos, as fotos, os textos, os sons etc. Segundo Valero Sancho (2010), as infografias utilizam recursos mistos e linguagens de diversas procedências. Essa variedade de elementos evita que as pessoas se percam no acúmulo de palavras, permitindo que um texto possa ser compreendido de maneira mais rápida e entretida (Leturia, 1998).

Como uma representação visual dos dados, da informação ou do conhecimento (Huang, Tan, 2007), a função fundamental da infografia é "informar através do desenho composto de elementos gráficos e textuais" (Rodrigues, 2009: 23). Na web, a infografia utilizada de maneira individual, sem ser complementar a um texto, deve ser compreensível como se estivesse em contexto. "Em geral este tipo de infografia, que não é complemento, é um storytelling em si mesma. Uma narrativa em si mesma. Não deveria depender de elementos exteriores" (Tascón, 2013).

Como exemplo deste tipo de infografia é possível citar a Guerra na Selva (g1.globo.com/am/amazonas/guerra-na-selva/platb), publicada no site do G1 em 19 de agosto de 2013, mostrada na figura 2.

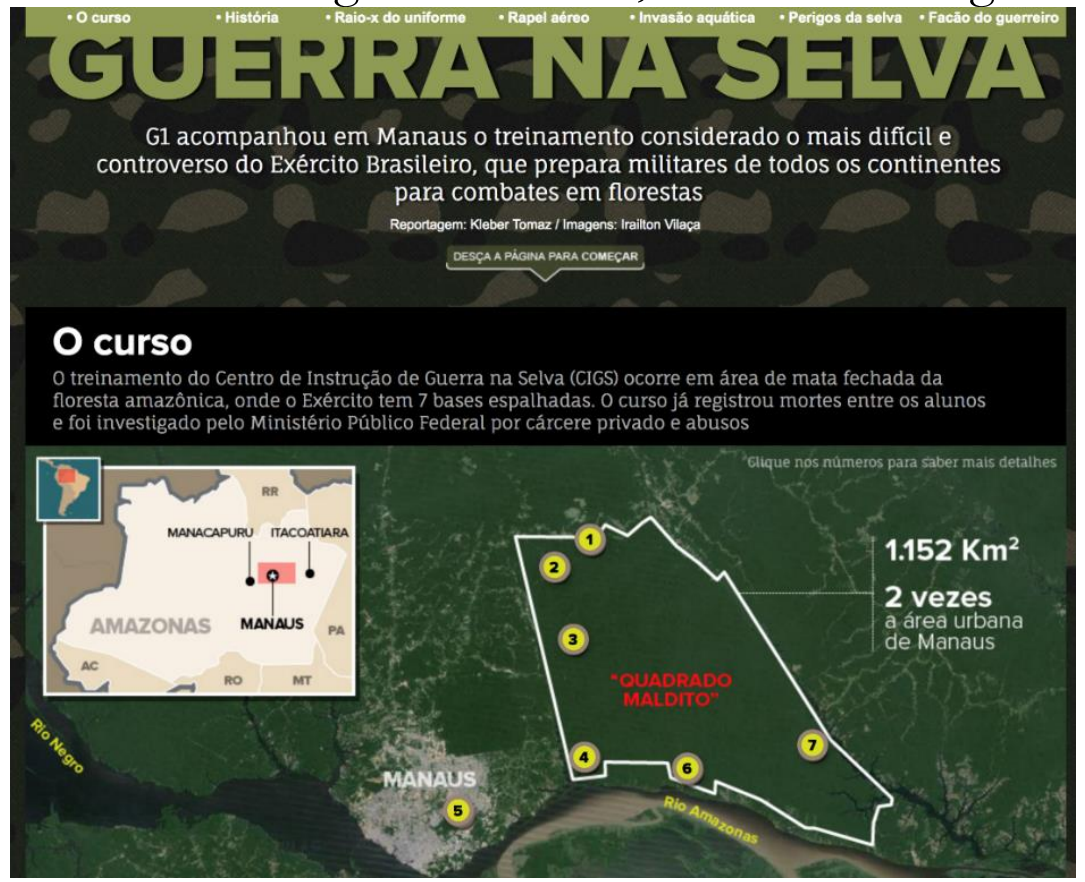

Figura 2: Página Inicial da infografia Guerra na Selva. Fonte: http://g1.globo.com/am/amazonas/guerra-na-selva/platb 
O material trata de um difícil e controverso treinamento do Exército Brasileiro em Manaus (AM), que prepara militares de todos os continentes para combates em florestas, contando com animações, gráficos e mapas interativos, GIFs animados, galeria de imagens e de áudio.

Em 2014, este trabalho recebeu premiação pela SND Digital na categoria Use of multimedia. O evento é organizado pela Society For News Design, nos Estados Unidos e elege os melhores trabalhos gráficos de revistas e jornais.

O setor jornalístico foi pioneiro na pesquisa e na apresentação de conteúdos no formato infográfico, contribuindo significativamente para seu avanço, com aproveitamento das possibilidades fornecidas pelas novas tecnologias. Por meio de seus exemplos, outros setores apropriaram-se deste recurso, como o educativo. Segundo Moraes (2013), a infografia deve ser usada sempre que ela aparecer como melhor resposta para a pergunta: "como o assunto pode ser melhor compreendido?".

No âmbito educativo, a infografia permite oferecer uma informação mais completa e precisa. $\mathrm{Na}$ web, possibilita contar histórias mais complexas com

ordem e ritmo de apresentação determinados pelo aluno, fazendo com que o processo de ensino-aprendizagem ocorra de maneira mais fluida e de acordo com o ritmo de cada um. De acordo com Lapolli, Vanzin e Ulbricht (2014: 42) "[...] a diversidade de recursos comunicativos que podem ser inseridos nesta ferramenta permite que os alunos acessem os conteúdos de acordo com suas preferências".

O acesso aos conteúdos de acordo com as preferências e necessidades dos alunos é pressuposto para a acessibilidade. Pensando em conteúdos para o público surdo, a infografia na web possui diversas características que favorecem a apresentação de materiais didáticos para esses indivíduos, como pode ser verificado no próximo item.

\section{Infografia educativa para surdos}

O termo 'surdos' sugere um coletivo homogêneo, no entanto, isto está muito longe de ser considerado verdadeiro: 
'Dependendo do tipo de surder, o momento em que a adquiriu e o nivel linguistico alcançado até esse momento, uma pessoa pode compreender, quase compreender e ter problemas reais para compreender um simples texto. Deste modo, pode-se afirmar que cada pessoa surda aprende no seu ritmo e, o mais importante, que este ritmo é nitidamente diferente ao de seus colegas ouvintes. (Lapolli, 2014: 54).

O que é ponto pacífico entre diversos pesquisadores (Capovilla, 2002; Farjardo et al., 2008; Ottaviano et al., 2010; Nordin et al., 2013; Lapolli, 2014) é que a visualização contribui para a aquisição de conhecimento, comunicação e consequente aprendizagem dos surdos. Um dos motivos é sua dificuldade de leitura de textos longos. Por esta razão, a língua de sinais é considerada a mais importante maneira de comportamento social deste grupo, bem como a mais conveniente ferramenta de comunicação (Zaharudin, Nordin, Yasin, 2011).

Lapolli (2014) trouxe a infografia como recurso ideal para apresentação de conteúdos para os surdos devido a seu forte apelo visual associado à utilização de textos curtos, claros e objetivos. Além disso, na web, torna-se possível a inserção de vídeos com tradução dos textos para a língua de sinais. A pesquisadora aponta uma série de diretrizes para a realização de narrativas infográficas na web utilizadas no processo de ensino-aprendizagem dos surdos. Revela apontamentos realizados por pesquisadores de diversas áreas, alunos surdos, bem como por especialistas da área de infografia. Entre eles destacam-se:

- A gravação dos vídeos em língua de sinais, deve ser acompanhada por uma pessoa surda que, inclusive, apareça nos vídeos que farão parte da narrativa infográfica.

- As narrativas infográficas devem ser criativas e devem despertar a curiosidade do intérprete, contendo elementos persuasivos e informativos, com uma interface de abertura que serve de sumário mostrando o que tem dentro do documento.

- Pode haver uma tela de entrada estética que, ao ser clicada, o intérprete seja direcionado para a tela principal.

- A tela principal deve ter algum tipo de sinalização mostrando onde estão localizadas as zonas ativas (links), sem confundir os intérpretes. 
- Para acessar os links, deve haver uma hierarquia, estando ativos primeiramente aqueles com conteúdos mais simples.

- As telas devem ser o mais o simples possível, tanto na sua forma como no seu conteúdo, utilizando metáforas simples e fáceis de entender.

- As imagens devem dar ênfase às explicações mais importantes e não devem sobrecarregar a carga cognitiva do estudante.

- Os textos devem ser curtos e concisos.

- A tipografia deve convidar o usuário a ler, sendo visual, atrativa e hierarquizada.

- O fundo das telas não deve interferir na leitura dos textos.

- Para não poluir o ambiente com janelas de vídeo, recomenda-se colocar um pequeno link ao lado dos textos para abrir a tradução em língua de sinais.

- A janela do vídeo em língua de sinais deve ter um tamanho que permita visualizar bem os movimentos das mãos e a expressão facial do intérprete.

- Sobre a tradução dos vídeos, alguns surdos defendem que ela deveria ser um pouco mais extensa que os textos apresentados em português, explicando o conteúdo de forma mais detalhada.

- As legendas dos vídeos em língua de sinais devem aparecer sempre que palavras muito grandes são soletradas, não sendo necessário utilizar a soletração de uma mesma palavra mais de uma vez. Para esclarecer melhor o significado dessas palavras, recomenda-se a realização de um glossário em língua de sinais.

- Para contribuir com a aprendizagem do usuário, a apresentação dos conteúdos deve estar próxima à sua realidade.

Sempre que se estiver desenvolvendo conteúdos voltados para as pessoas surdas é preciso traçar um olhar para as potencialidades de seu corpo. Para Marques (2007: 85), as pesquisas não devem tentar corrigir o corpo da pessoa surda, mas sim descobrir [...] novas potencialidades, viabilizando, através da tecnologia, a criação de novas estratégias que atendam às necessidades das pessoas surdas.

Deste modo, se faz necessário despertar um outro ponto de vista para o tema da surdez que, por muitos anos, vem sendo tratada como deficiência. "Como se os parâmetros para se relacionar com o mundo 
fossem validados somente por meio da perspectiva dos ouvintes" (Lapolli, Vanzin, Valero Sancho, 2018: 159). Estes autores destacam que o mundo pode ser percebido por toda as vias, de forma diferente para cada indivíduo que é levado a mergulhar num mundo subjetivo.

\section{Considerações finais}

As narrativas visuais possuem o potencial de dialogar com as subjetividades e o imaginário dos intérpretes, construindo diversos significados. A linearidade dos códigos verbais é rompida nestes materiais, trazendo novas possibilidades de leituras capazes de atender as necessidades e preferências do público, principalmente quando alocados na web. Por este motivo, conforme é apontado nesta pesquisa, este recurso é adequado ao surdo, que possui maneiras particulares de se relacionar com o mundo.

O intuito deste artigo foi apresentar exemplos de narrativas visuais jornalísticas na web que servem de modelo e estímulo para a criação e o desenvolvimento de narrativas infográficas no setor educativo. Compreendeu-se que as narrativa visuais são capazes de potencializar a apreensão de conteúdos, ainda mais quando se trata de um público que demonstra predileção pela visualização como forma de aquisição de conhecimento. Contudo, a criação e o desenvolvimento de narrativas infográficas na web voltadas para a educação dos surdos, exige o atendimento de algumas diretrizes que aparecem na pesquisa de Lapolli (2014) conforme revelado no item anterior. Ao considerar estes tópicos, a equipe de desenvolvimento de materiais didáticos, direcionado aos surdos, no formato de infografia, abre portas para a acessibilidade. O benefício gerado é a inclusão de milhares de pessoas, que passam a ter acesso total aos conteúdos apresentados. 


\section{Referências}

Braga, M. \& Silva, R. H. (2010). O Jogo das narrativas: encadeamentos narratológicos do game The Sims. Brasília: E-Compós, v. 13, pp. 1-16

Capovilla, F. C. \& Capovilla, A. G. S. (2002). Educação da criança surda: o bilinguismo e o desafio da descontinuidade entre a língua de sinais e a escrita alfabética. Revista Brasileira de Educaşão Especial, v.8, n.2, pp.127-156

Farjardo, I., Arfé, B., Altoé, G., Benedetti, P. (2008). Hyperlink Format, Categorization Abilities and Memory Span as Contributors to Deaf Users Hypertext Access. Journal of Deaf Studies and Deaf Education, v. 13 (1), pp. 87-102, Dez.

Gil, A. C. (2008). Como elaborar projetos de pesquisa. São Paulo: Atlas.

Huang, W.; Tan, C. L. (2007). A System for Understanding Imaged Infographics and Its Applications. DocEng'07, August 28-31. Winnipeg (Canada)

Lapolli, M. (2014). Visualização do conhecimento por meio de narrativas infográficas na web voltadas para surdos em comunidades de prática. Tese. Brasil: Universidade Federal de Santa Catarina

Lapolli, M., Vanzin, T.; Valero Sancho, J. L. (2018). Infografias para surdos e os segredos do mundo visível. In: Ulbricht, V. R.; Fadel, L. M.; Batista, C. R. Design para acessibilidade e inclusão. São Paulo: Blucher, pp. 151-161.

Lapolli, M., Vanzin, T., Ulbricht, V. R (2014). Organização da informação em narrativas infográficas na web voltadas para o processo de ensino-aprendizagem. Infodesign, v.11 (1), pp.36-49

Leturia, E (1998). ¿Qué es infografía? Revista Latina de Comunicación Social, abril, n. 4. www.ull.es/publicaciones/latina/z8/r4el.htm. Acesso em: 02. mai 2018.

Marques, R. R. (2007). A percepção do corpo próprio e o "ser surdo". Ponto de Vista, 9, pp. 75-85

Moraes, A. (2013). Infografia: história e projeto. São Paulo: Blucher

Murray, J. H. (2003). Hamlet no holodeck: o futuro da narrativa n ciberespaço. São Paulo: Itaú Cultural 
Nordin, N. M., Zaharudin, R., Yasin, M. H. M., Din, R., Embi, M. A., Lubis, M. A. (2013). ICT in education for deaf learners: Teachers' perspective. Research Journal of Applied Sciences, v. 8, pp.103-111

Ottaviano, S., Merlo, G., Chifai, A., Chiazzese, G., Seta, L., Allegra, M., Samperi, V. (2010). The deaf and online comprehension texts, how can technology help? In: Miesenberger, K., et al. (eds.). ICCHP, Part II, LNCS 6180, pp. 144-151

Rodrigues, A. V. (2009). Infografia Interativa em base de dados no jornalismo digital. Dissertação. Universidade Federal da Bahia, Salvador

Silva, E. L. \& Menezes, E. M. (2005). Metodologia da pesquisa e elaboração de dissertação. 4. ed. Florianópolis (Brasil): Universidade Federal de Santa Catarina

Valero Sancho, J. L. (2010). La comunicación de contenidos en la infografía digital. Estudios sobre El Mensaje Periodístico, v. 16, pp. 469483

Zaharudin, R., Nordin, N., Yasin, M. H. M. (2011). Online ICTcourses integrated for the hearing-impaired individuals' education: a preliminary study from the students' perception. Informatics Engineering and Information Science Communications in Computer and Information Science, v. 251, Part 1, pp. 56-63 



\title{
VIIII
}

\section{Hiperinfografia: onde está a visualização sintética no jornalismo de nova era?}

\author{
William Robson Cordeiro (•). UFSC (Brasil), UAB (Espanha). \\ williamdefato@gmail.com
}

José Luis Valero Sancho (†). Departamento de Comunicação Audiovisual e Publicidade. UAB, Espanha.

joseluis.valero@uab.cat

Resumo: É certo que o jornalismo pós-industrial apresenta mudanças profundas na produção e no consumo de notícias e tais alterações também passam fortemente pelas linguagens e formatos. Quanto à visualização sintética, em especial, não se caracteriza tão somente na transição entre o analógico e o digital, porém as transformações se aprofundam no ambiente da hipermídia. Este é o caminho a que se propõe percorrer este estudo: refletir sobre a fronteira onde se apresenta uma nova categoria de infográficos, de natureza complexa e imersiva. Ou seja, como se manifesta a infografia neste contexto? O intuito é acompanhar algumas produções jornalísticas, de modelos imersivos, tridimensionais, de realidade virtual, com o objetivo de categorização e construção conceitual do que denominamos, a priori, de hiperinfografia. $\mathrm{O}$ acréscimo do prefixo hiper determina o ambiente destas infografias e, do mesmo modo, a sua grandeza e sofisticação. 
Palavras-chave: Hiperinfografia; visualização sintética; jornalismo; infografía.

\section{Introdução}

TãO parecem surpreendentes as abordagens que tratam das 1 muitas formas e manifestações de infografia quando de sua transição do estático para o universo online. É preciso considerar os estudos que delimitaram esta fronteira e nos esquemas que trabalham seu estágio, os quais pretendemos mostrar mais adiante. $O$ que demonstra ser novo é a transformação da visualização sintética no ambiente da hipermídia.

Ou seja, não se refere mais a tão claramente observada transição entre o analógico e o digital. Porém, versa para expressões diferentes em um mesmo ecossistema, considerando, desta vez, formatos online mais complexos.

O infográfico online trata-se de uma forma narrativa totalmente nova e cada vez mais presente no dia-a-dia do jornalismo. Sobretudo, por sua capacidade de facilitar a compreensão de temas aparentemente complexos com linguagem de fácil entendimento, e com destaque à visualidade (Ochoa, 2009: 265). Igualmente significa fugir da ortodoxia do jornalismo tradicional de contar histórias com ênfase nos recursos de texto e foto, tradicionalmente observados no jornalismo impresso, embora também reproduzidos no online.

O contexto do denominado "jornalismo pós-industrial" caracteriza por uma mudança nas formas narrativas jornalísticas. $O$ mercado jornalístico atual exige métodos de trabalho diferenciados e processos baseados em mídias digitais que pressupõem mudanças nos formatos e no empacotamento da notícia, com sugestões que passam por novas formas de contar histórias.

Podemos incluir a infografia como elemento destas transformações, por sua natureza versátil de funcionalidade. Sabe-se que este recurso jornalístico não é recente, é praticado por jornais desde o século XVII, porém caminha por novas formas de apresentação de conteúdos noticiosos. Ochoa (2009: 265), ao referir-se ao Salaverria (2008: 21) 
constata o avanço deste "gênero específico e consolidado que mais rapidamente tem aproveitado as características do ciberespacoo".

O jornalismo se coloca numa instância simbólica, porém, se manifesta concretamente através de seus gêneros e formatos. Para que qualquer discurso jornalístico se consolide é necessário que um modelo tecnográfico exista e aja como mecanismo de sua apresentação e compreensão. Este cenário que envolve os formatos (sobretudo no contexto do jornalismo convergente, pós-industrial ou de nova era), inclui a infografia, um recurso que congrega diversas linguagens em si mesmo, se apresenta de variadas formas e em suportes diversos, por código social e efetivamente aceito (Vidal, 2017).

Periódicos têm mostrado interesse em fornecer formatos mais dinâmicos e eficientes para noticiar acontecimentos e, para tanto, recorrem a modelos como slides shows, especiais multimídia, Grande Reportagem Multimídia (Longhi, 2014), newssgames, todos com alta capacidade expressiva, narrativa e de imersão ${ }^{53}$. Este cenário instiga uma investigação tanto do processo de evolução da infografia, quanto de sua manifestação no jornalismo convergente.

É certo que muitos estudos, livros, artigos já relataram sobre sua evolução no jornalismo e sobre o status alcançado no ambiente online. Este caminho sugere algumas indagações que podem levar a compreender o fenômeno que ora se apresenta.

${ }^{53}$ Um estudo recente (Cordeiro e Costa, 2016), publicado na revista Leituras do Jornalismo, levanta reflexões conceituais ainda dissonantes sobre o chamado "jornalismo imersivo". De que maneira os novos formatos jornalísticos contribuem para uma maior experiência no consumo de notícias? O artigo publicado observa que os níveis de imersão não se associam unicamente a um aparato tecnológico ou de "estimulaşão sensorial" (Murray, 2012: 101), porém há aspectos psicológicos, filosóficos e narrativos que precisam ser considerados. A transposição da consciência para estas múltiplas realidades possíveis pode ser realizada, portanto, através de dispositivos tecnológicos ou artísticos. O espetáculo de teatro e a linguagem funcionam como passagens para estas sensações, assim como as novas tecnologias. Dominguez (2010: 4) lembra que o acionamento desta qualidade psicológica ocorre invariavelmente via algum dispositivo, não necessariamente técnico, como o livro, por exemplo. 
Onde se encontra a infografia jornalística no contexto do jornalismo pós-industrial, de nova era? A questão, ampla, abrange diversas formas de expressão da infografia. Estáticas, interativas ou animadas se inserem neste contexto. A indagação que levantamos pretende ir mais além, com olhar mais aprofundado sobre os movimentos recentes dentro de uma visualização sintética complexa que utiliza recursos expressivos sofisticados.

\section{De que maneira se manifesta e é desenvolvida pelos periódicos?} Os estudos que envolvem a temática de infografia ou visualização da notícia, formalmente, delimitaram em três os estágios para estruturar sua evolução histórica, como veremos adiante. Estes estágios nos ajudarão a nortear nosso percurso.

Ambas as questões abrem margem para uma amplitude de respostas, ao observar que o caminho percorrido pela infografia no jornalismo apresenta fases distintas e não-excludentes, que convivem mutuamente no cenário do jornalismo convergente.

De semelhante modo, indicam para um universo pouco observado, embora já efetivamente praticado pelos periódicos: uma nova fase em andamento, da qual estamos atento, com amplas características expressivas. Necessita ser vastamente dissecada em suas categorias e estruturas. Como, por exemplo, os modelos denominados de infografias jogáveis (playable infographics) (Bogost; Ferrari; Schweizer, 2010), 3D, 4D, realidade virtual e visualização.

Tal contexto caminha para um provável quarto estágio dos infográficos que possam abarcar estes novos exemplos de caráter imersivo ou mesmo desembocar numa estrutura em comum, que congrega a visualização da notícia (apresentação) e a visualidade da notícia (estética) - distinções observadas por Valero Sancho (2012). O foco, portanto, caminha para além destes estágios, considerando grupo de infografias com altas capacidades expressivas no jornalismo e, portanto, esta fase vem sendo denominada, inicialmente de biperinfografia. 
A priori, a definição de hiperinfografia englobaria modelos ou conjunto de modelos de infográficos de alta capacidade expressiva e imersiva, disponíveis no ambiente hipermidiático. Estudo prestes a publicação (Longhi, Cordeiro, 2018: 6) acrescenta que a hiperinfografia também tem característica autônoma, sem a necessidade de texto ou reportagem que o complemente. E que o prefixo "Hiper" pode ser tanto relacionado à "grandeza" quanto ao ambiente. "Ou seja, se caracteriza em suas manifestaçoes complexas na hipermidia, e se materializa em formatos mais sofisticados em termos de visualização sintética" (Longhi, Cordeiro, 2018: 6, no prelo).

\section{Visualização e visualidade}

A infografia, expressão que deriva do inglês infomational graphics, é um gênero amplamente utilizado por periódicos em todo o mundo e tornase mais comum também no cotidiano da vida social. Os infográficos se propõem a gerar representações sintéticas (construídas realisticamente) de eventos, de acontecimentos, considerando o uso de diagramas, de desenhos, vídeos, animações, e linguagem iconográfica. Podemos dizer que não se trata de algo novo. Há registros pontuais em jornais impressos estadunidenses e europeus desde o século XVII, “em sua maioria, rotas de guerra, em forma de mapas contendo alguns dados estatísticos, refletindo o contexto social e cultural daquela época" (Rodrigues, 2009: 196).

Estes seriam exemplos originais, formas incipientes da infografia nos meios de comunicação, denominados "infográficos de primeira geração" ou "proto-infográficos" (Teixeira, 2008: 164). E se caracterizavam pela ausência de elementos frequentemente empregados nos infográficos modernos, tais como "texto de entrada e outros complementares" (Teixeira, 2008: 164), por exemplo.

Com a internet, as estruturas infogramáticas se tornaram mais amplas. No início, a infografia enfrentou mudanças importantes, deixando seu formato estático e adotando elementos interativos. A oferta ao usuário era precária, com poucos elementos clicáveis. Até alcançar, enfim, estágios mais evoluídos tanto no aspecto de interface, interatividade quanto em apresentação estética. 
Os estudos formais da infografia classificaram o gênero, até agora, em três fases evolutivas, que embora pareçam sequenciais no aspecto cronológico, não são excludentes. Exemplos de cada uma das fases ainda coexistem no jornalismo.

Rodrigues (2009: 201) explica estas três fases. Cita a infografia de primeira geração, de caráter estático, notadamente observado no suporte impresso, de narrativa sequencial e linear. A autora aponta características das três fases pelas quais a infografia ainda percorreu, tais como os modelos clicáveis e multimídia até as infografias em banco de dados.

Outros autores (Sancho, 2001; Amaral, 2010; Teixeira, 2010; Cordeiro, 2013) registraram estas etapas em seus estudos, os quais já abordamos, muito recorrentemente, em artigos anteriores, que confluíam para um mapeamento destes "estágios evolutivos" dos infográficos.

Tais etapas reforçam a compreensão de como a hipermídia ampliou o potencial, as funcionalidades e a dos infográficos jornalísticos. Ou seja, as mudanças se deram organicamente no ambiente da hipermídia, além da simples transposição de suportes, ampliando as suas potencialidades expressivas $^{54}$.

A hipótese do surgimento de uma fase posterior às três apresentadas é o intuito deste artigo. Vidal (2017: 55), em recente tese defendida na Universidade Autônoma de Barcelona (UAB), oferece pistas de um fenômeno novo na transmissão de dados, sobretudo em tecnologia multimídia e de síntese que incorpora diferentes linguagens na mensagem. "Podemos falar de texto e imagem, mas também de som, movimento, biperlinks (navegação), interatividade, 4D (3D mais linha do tempo) e tudo isso aponta a que a linguagem será integradora de diferentes linguagens" (Vidal, 2017: 55). Este cenário, de maior integração e complexidade, gera discussões

${ }^{54}$ Longhi (2015: 2) trabalha desde a construção de gênero expressivo a partir do audiovisual, aos "formatos noticiosos hipermidiáticos" como os infográficos interativos ou clicáveis e, em especial, a Grande Reportagem Multimídia (GRM). Para operacionalizar suas pesquisas sobre os formatos expressivos, a autora distinguiu os produtos nos quais "as possibilidades expressivas próprias da bipermídia são utilizadas na sua concepsão", dos formatos ortodoxos que agrupam imagem e texto. 
para que se investigue a evolução e a transformação do que ocorre com a visualização sintética no jornalismo pós-industrial.

Para começar, adentremos no contexto atual em que o jornalismo se insere e como afetou suas linguagens e formatos. Anderson, Bell e Shirky (2013: 32) recorrem à expressão "jornalismo pós-industrial" para designar o momento vivido pela atividade. Trata-se de um termo empregado em 2001 pelo jornalista Doc Searls, ao relacionar o antigo modo de produção e sua dependência de maquinário gráfico ao modo vigente que dispensa esta estrutura.

O relatório produzido no âmbito da Tow Center for Digital Journalism, da escola de jornalismo de Columbia, detalha as transformações em curso e suas tendências, com previsões (vez por outra, apocalípticas) de que o jornalismo estadunidense irá "piorar ainda mais e, em certos lugares, piorar muito".

Os autores ainda sugerem saídas para o que parece estar vislumbrando uma tragédia para o setor, que passa necessariamente pelas técnicas e ferramentas nunca antes imaginadas para a atividade. "Explorar novos métodos de trabalho e processos viabilizados pelas mídias digitais" (Anderson, Bell, Shirky, 2013: 38).

Este ponto mostra um caminho amplo e igualmente aberto de possibilidades para este jornalismo que se apresenta. Os formatos em transformação é um fenômeno intrigante e, ao mesmo tempo, animador. Baseado nas recomendações que constam no relatório de Columbia, explorar novas formas de comunicar o que é de interesse do público tem a ver com o que se exige do atual jornalismo convergente.

A superabundância de dados disponíveis na rede requer dos jornalistas uma habilidade especial de garimpagem, decupagem e apresentação destes dados. Em outras palavras, a competência destes jornalistas "pós-industrial" exige domínio na leitura, capaz de interpretar dados, gerar narrativas compreensíveis à audiência e de que maneira esta informação pode ser melhor assimilada (se por texto ou imagem sintética). 
Para que o jornalismo mantenha sua relevância, gente que trabalha na área terá de melhorar seu traquejo no uso de dados. À medida que individuos, empresas e governos vão criando e soltando dados em volume cada vez. maiores, vemos que disponibilidade e acessibilidade, no caso de dados, são coisas distintas. (Anderson, Bell, Shirky, 2013: 49)

Está aí a sutil diferença entre visualização e a infografia propriamente dita. Embora pareça sinônimos (em algumas observações, sim), sua distinção está essencialmente atrelada à apresentação, por um lado, e estética, por outro. Infografias esteticamente vistosas podem ser consideradas como formato específico em termos de visualização de dados. O contrário nem sempre funciona, por considerar que a visualização pressupõe ser uma infografia de leitura menos acessível.

Cairo (2011: 33) afirma que o "desenho da informação é a parte fundamental da visualização" e que, mesmo com a relação do termo com a informática (a linguagem dos programadores), não dissocia da sua forte conexão com a infografia. Ao contrário, sugere uma definição que considera mais simples, a de que "que a visualização consiste no uso de representações gráficas para ampliar a cognição" (Cairo, 2011: 33). E, sendo assim, "os nomes visualização e infografia denominam uma única disciplina".

Em perspectiva mais ampla, Sancho (2012) estrutura parâmetros denominados por este autor de "visualização sintética" e "visualidade estética". Ambos, neste caso, são "produtos comunicativos e de capacidades culturais de valor agregado". Neste caso, estes valores estão condicionados ao uso das novas tecnologias (fig.1).

A visualização combinada com a visualidade gera o "relato visual infográfico", também considerado síntese. O limite semântico entre ambos não é bem definido, como se pode notar, e alcança até mesmo "confusão tecnográfica-estética" (Sancho, 2012: 19).

Faz-se necessário explicar que todo relato infográfico é uma síntese, ou para ser mais abrangente, que toda apresentação de dados em forma de visualização é um síntese. De acordo com Sancho (2012: 18), para quem a síntese é a natureza do formato. consiste em elaborar um produto novo ou novidades a partir de múltiplos dados dispersos em documentos on 
conectados de alguma maneira a acontecimentos que alguém acumula, organiza e com os quais elabora produtos como desenho de ocorridos e descrições diversas de atos.

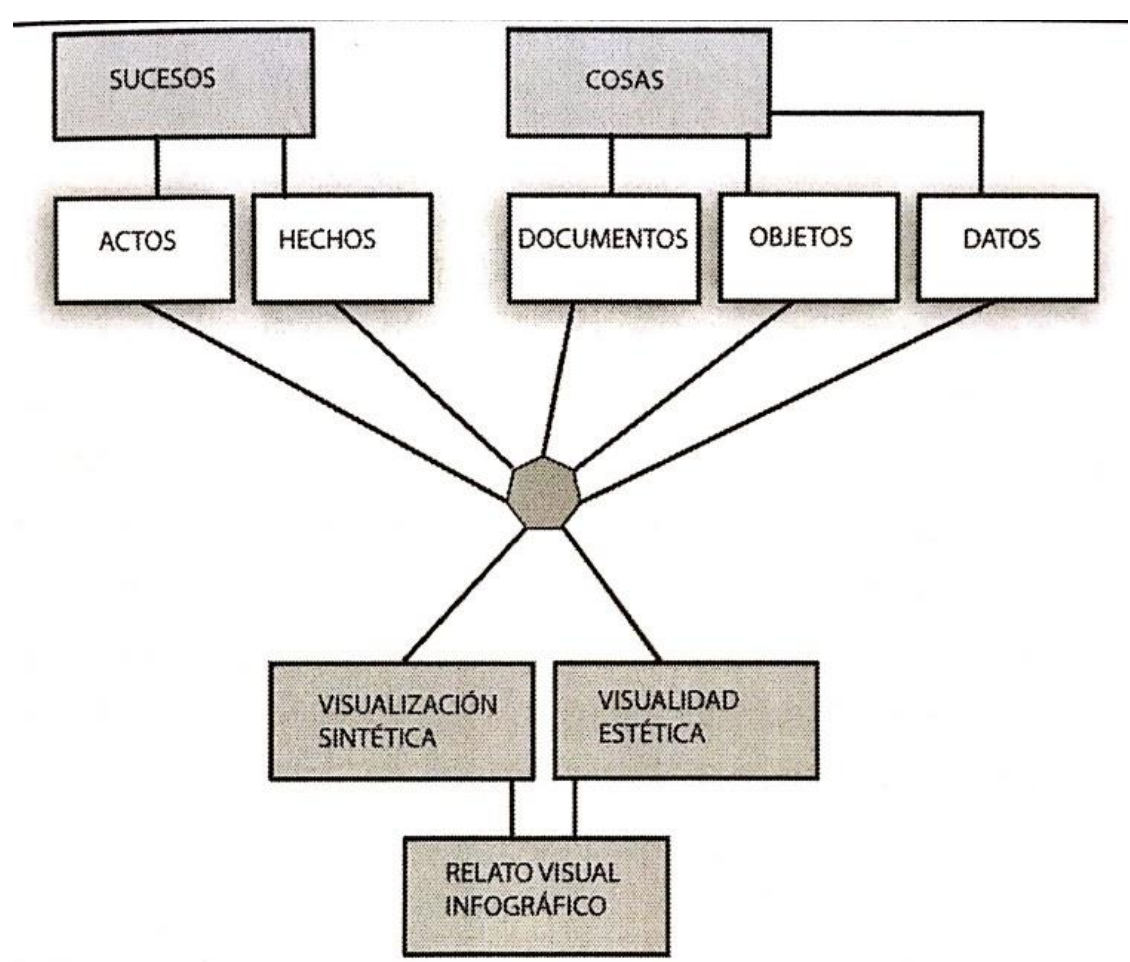

Figura 1. Gráfico em que explica o relato infográfico como a combinação da visualização sintética e a visualidade estética. Fonte: Sancho, 2012: 13.

Para o autor, as propriedades sintéticas da infografia apresentam duas qualidades distintas e peculiares, que são a sua utilidade documental e a sua visualidade estética. Assim define:

Utilidade documental: conjunto de qualidades que contribuem com a função de relatar acontecimentos. Estas qualidades são caracterizadas por "conteúdos informativos e documentais, significação, focalização, grau de sintese, resumo, complemento e substituição, rigor informativo, documental e de concordância” (Sancho, 2012: 40).

Visualidade estética: está relacionada com o modo de apresentação para o leitor, baseado na "forma ou aspecto, clareza e didática, estética, sígnica formal, anamorfoses diversas" (Sancho, 2012: 44). 
A visualização se revela em síntese, não necessariamente trabalhada sob o caráter estético. Agrupa, define e organiza dados. A síntese infográfica, portanto, está profundamente situada no cenário do jornalismo pós-industrial, com estes elementos que a particularizam.

\section{Revivendo os megagráficos}

Em uma sessão de orientação de tese com o professor Jose Luis Valero Sancho, em que iniciávamos as discussões quanto às recentes manifestações de infografias online -aquí denominadas de Hiperinfografia - recordamos de um fenômeno similar e observado no jornalismo impresso. No início dos anos 2000, os diários traziam grandes produções infográficas para explicar determinado acontecimento, quando não tinham registros fotográficos à disposição. Os infográficos precisariam impactar de forma a chegar aonde a foto não chegaria.

Assim, nasceram os chamados "megagráficos", que nada mais são que infografias de página inteira (ou sequenciadas nas páginas seguintes) que substituíam a fotografia e o texto tradicional (fig.2). Sancho tratou do protagonismo dos "megagráficos" como elemento-chave para narrar a Guerra do Golfo. "A própria infografia passava a ser parte da notícia, era comentada e objeto de comparação e admiração" (Sancho, 2001: 177).

Os "megagráficos" apresentavam forma peculiar de transmissão da notícia naquele momento. Percebeu-se a natureza dinâmica do gênero, como elemento vivo na atividade jornalística. Este dinamismo percebido no jornalismo impresso no início do século, é também notado no jornalismo online com os "hiperinfográficos". Também é um retorno ao exercício reflexivo acerca das novas fronteiras da infografia desenvolvido por Contreras (2000), ao riscá-las entre os ambientes analógico e online, adentrando no cibermundo das mudanças substanciais das imagens sintéticas e nos seus limites entre a ficção e a realidade. Desta vez, a fronteira imaginária estaria na própria hipermídia, ao considerar a sua natureza complexa. Definir esta fronteira é o grande desafio. 


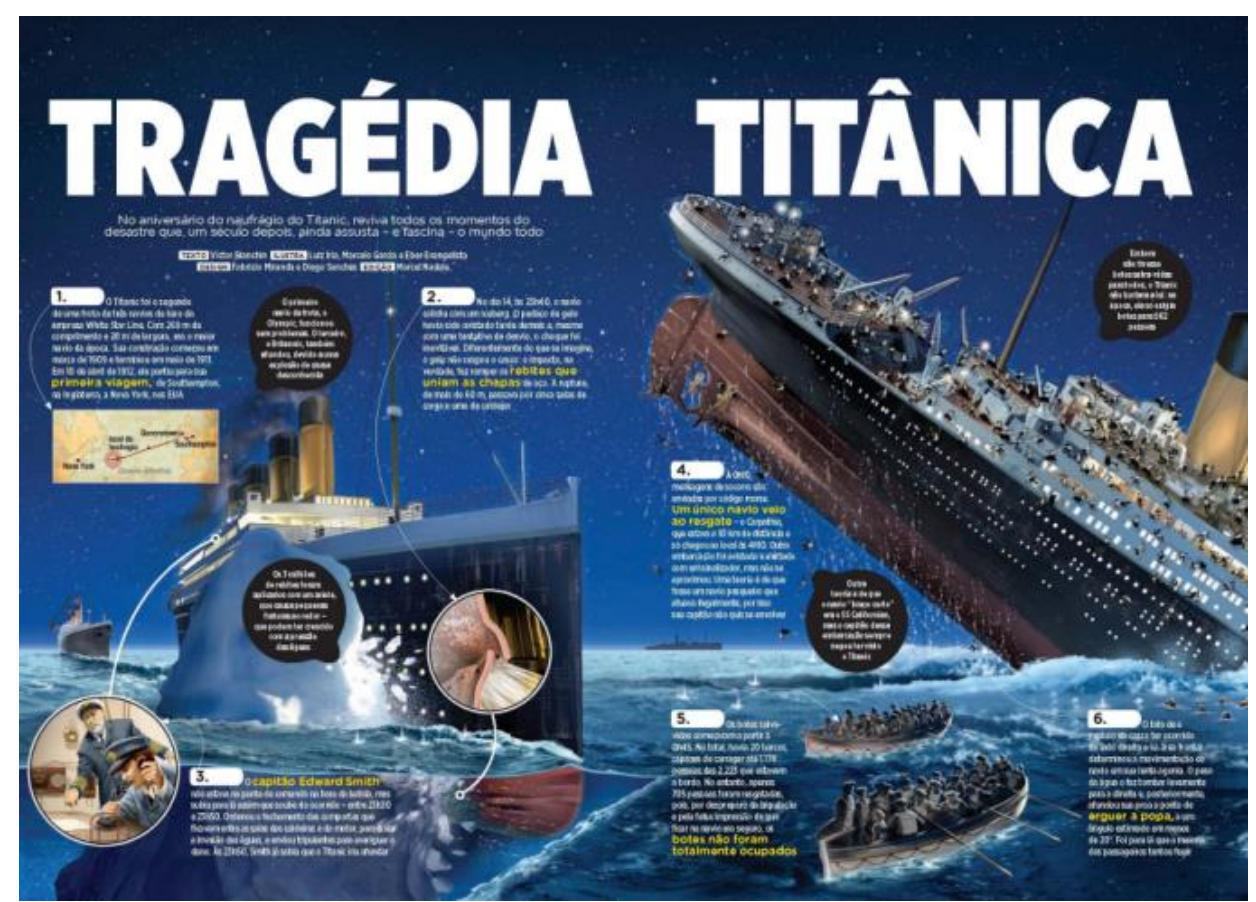

Figura 2. Exemplo atual de megagráfico, publicado pela revista Mundo Estranho em 2013 e vencedor do prêmio Malofiej. Fonte: https://bit.ly/2yb1Cz4

A hiperinfografia se encontra no âmbito dos formatos hipermidiáticos (visualização e visualidade), através de exemplos como os modelos de caráter imersivo, com recursos tridimensionais, ubicativos (Google Earth, imagens de satélites, drones), animações e videojogos. Sugere uma nova categoria evolutiva, da qual estamos atentos, um provável quarto estágio que possa envolver novos exemplos de caráter complexo. Ou novos aportes da infografia para um jornalismo de nova era.

\section{Hiper: potência e hipermídia}

A hiperinfografia, portanto, é uma proposta conceitual ainda em construção e que pretende estabelecer categorias que possam classificar de forma mais eficiente este gênero. A construção deste conceito intentará delimitar as novas formas de produção de infografia no jornalismo, considerando sua complexidade e suas potencialidades hipermidiáticas. Por esta razão, é importante estabelecer este limite, observar onde e como se manifesta este modelo de visualização sintética. 
Para isso, será necessário nesta análise, considerar a digressão inicial pelos três pontos já explicitados acima: a visualização de dados, que deixa este caráter para se tornar uma infografia propriamente dita; a visualidade, a natureza vistosa destes infográficos; e, por fim, as narrativas mais complexas, observando dentre tantas características, as imersivas, tridimensionais, 4D, de animações, ubicativas e videojogos. Para efeito metodológico, escolhemos quatro exemplos de infografias publicados em periódicos importantes (dois estadunidenses e dois brasileiros) e fizemos uma avaliação fundamentada no referencial teórico apresentado neste artigo. O intuito é contemplar um aparato teórico e empírico do tema. Evidentemente, a natureza dos exemplos pode ser modificada à medida que o conceito ganhe em consistência teórica e epistemológica.

\subsection{The Washington Post}

Para começar, o exemplo do infográfico imersivo do jornal The Washington Post, "Mars - An Interactive Journey" (fig.3). O diário gerou uma experiencia em realidade virtual que simula um passeio do usuário em Marte.

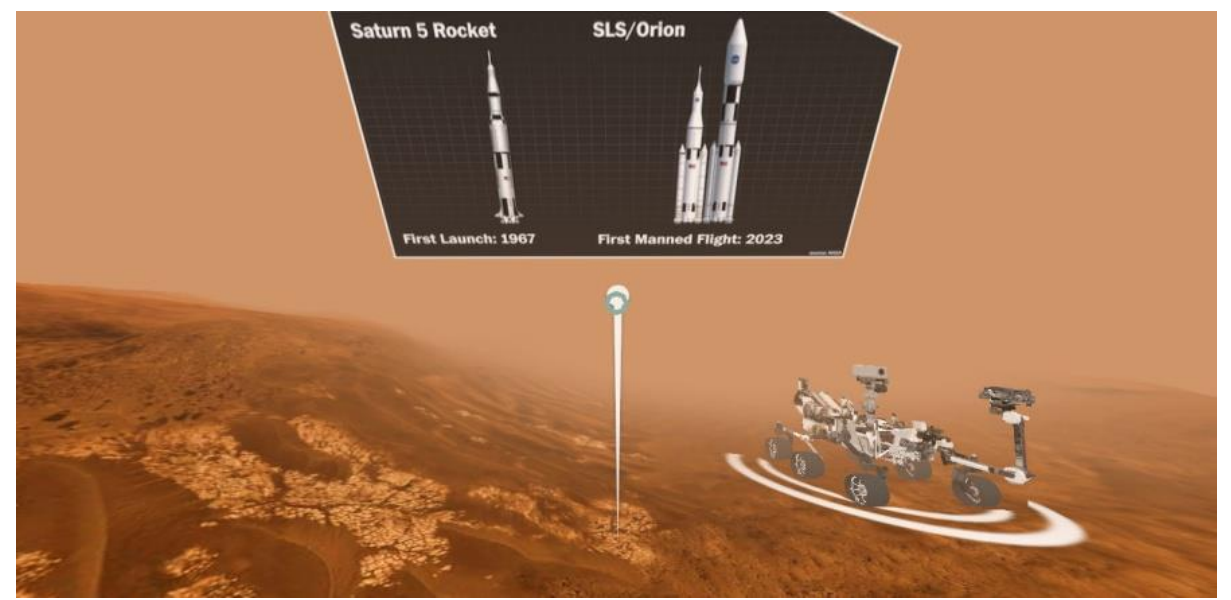

Figura 3. Infográfico do Washington Post representando a exploração de marte com realidade virtual. Fonte: https://wapo.st/2OjS92r

A reportagem, publicada em març,o de 2016, nasceu diante dos objetivos do governo estadunidense de explorar e enviar pessoas ao planeta. Pode-se considerar este produto como um infografico interativo imersivo, por retratar o ambiente de forma realística, incluir 
elementos de textos, desenhos, imagens e áudio para facilitar a compreensão e exigir uma ação do usuário.

Trata-se de um infográfico de implementação complexa, que exigiu participação de especialistas das áreas de conceituação, produção, engenheiro de software, designer, produtores de Realidade Virtual e cineasta. Este staff trabalhou em produçóes distintas, atendendo às demandas de quem utiliza o computador e para quem usa outro dispositivo, como os óculos de Realidade Virtual (RV). Para o exemplo em RV, o cenário desenhado e a disposição dos textos são diferentes do visto na web. Há maior mobilidade e uma participaçáa mais ativa do usuário proporcionada pelos óculos especiais.

Ao entrar no infográfico, um rápido tutorial mostra que durante a navegação despontarão hastes brancas e azuis que precisarão ser, marcadas por um pequeno ćrculo. Assim, o usuário obterá informaçónes adicionais produzidas pelo jornal (as brancas) e coproduzidas pelo patrocinador (as azuis).

\subsection{The Wall Street Journal}

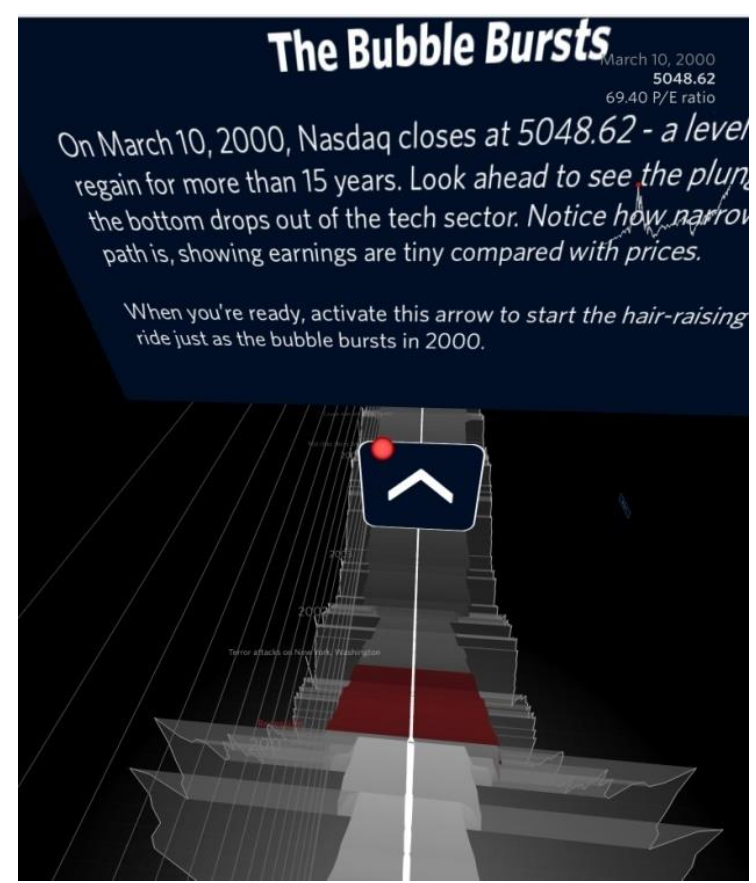

Figura 4. Infográfico do Wall Street Journal sobre os 25 anos da bolsa Nasdaq, com efeito imersivo no interior de um gráfico de febre. Fonte: https://bit.ly/1zThfTp 
$\mathrm{Na}$ sequência, outro infográfico com alta complexidade de imersão, desenvolvido pelo Wall Street Journal, em 23 de abril de 2015, para detalhar os altos e baixos da bolsa Nasdaq, que completaria 25 anos, o "Is The Nasdaq in Another Bubble?" (fig.4). Nada melhor que explicar estes altos e baixos através de um gráfico de febre. Porém, um gráfico de febre que coloca o usuário dentro dele para que descubra toda a evolução da bolsa, passeando como numa "montanha russa".

Roger Kenny e Ana Asner Becker foram os desenvolvedores deste infográfico, cujos efeitos e experiências somente se concretizam no contexto atual da hipermídia, sobretudo quando a sua natureza responsiva ainda abarca celular e tablet (tocando a tela e a movimentado para cima e para baixo), visualizadores de realidade virtual (usando o botão do visor) e desktops (através da barra de espaço).

Os infográficos com estes recursos especiais, tanto o do WSJ quanto do Washington Post, são antecedidos de tutoriais no intuito de garantir navegabilidade e aproveitamento do conteúdo. No exemplo do WSJ, as informações são apresentadas a partir da largura do caminho: largo (preço/lucro), estreito (ações mais altas em relação aos ganhos) e mais estreito indica uma bolha.

\subsection{Nexo}

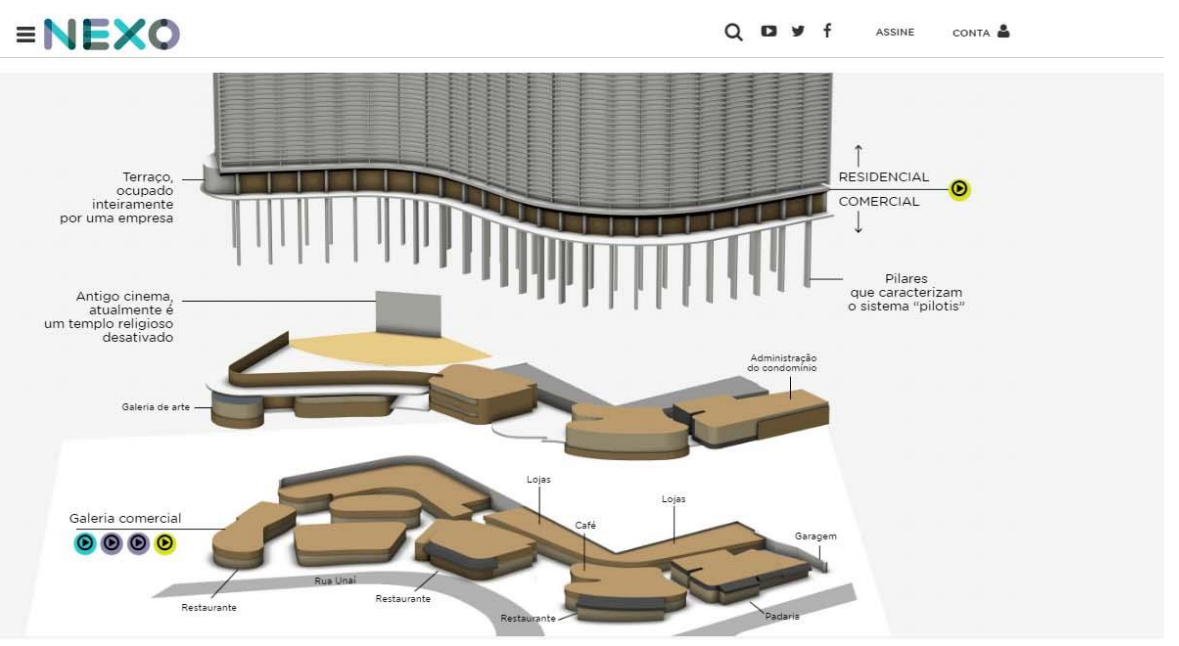

Figura 5. Infográfico do Nexo, em 3D e áudio, sobre os 50 anos do edifício Copan. Fonte: https://bit.ly/1RFkQMd 
Os modelos que recorrem à tridimensão e recebem tratamentos especiais de animações, são considerados como 4D. Este é o exemplo do jornal online Nexo, periódico que explora infografias em seu noticiário, muitas delas de característica estática e linear.

Em 2016, no entanto, ousou com este infográfico que representa a estrutura do condomínio residencial Copan, de São Paulo, que completaria 50 anos (fig.5). A peça está colocada dentro de uma reportagem sobre o tema e, uma Grande Reportagem Multimídia, no estilo scrollytelling.

Com este recurso, têm-se as primeiras impressões estáticas do prédio até chegar na imagem em 3D propriamente dita, embora como citado, ganha uma dimensão mais arrojada devido à animação e a todo movimento que o infográfico faz, a partir do clique do usuário. Este usuário é convidado a participar, mas o nível de imersão é baixo: a interatividade se dá através de botões que acionam áudios de especialistas que detalham aspectos de engenharia do edifício.

O infografista do Nexo, Rodolfo Almeida ${ }^{55}$, explicou que estes elementos têm contribuído para o entendimento da notícia. "Na internet, especialmente, as possibilidades são multiplicadas pelas ferramentas digitais, interativas, técnicas de narrativa guiada, scrollytelling, etc. Com isso, ela é muito útil para iluminar conceitos técnicos e estatísticos e contar histórias de forma que aproxime o leitor do assunto abordado".

\subsection{Folha de S. Paulo}

Este exemplo se assemelha à seção videográficos publicada pelo jornal Folha de São Paulo, que em 2014 publicou um infográfico em 3D mostrando todos os aspectos arquitetônicos do estádio Itaquerão, do Corinthians (fig o), que foi palco de abertura da Copa do Mundo. O jornal utilizou o Folhacóptero, figura criada originalmente para os newsgames do periódico paulista, que se ampliou para contar histórias em três e quatro dimensões. Ou seja, sem a interatividade do game, mas com alto potencial expressivo, o infográfico simula um sobrevoo sobre os principais pontos da arena.

${ }^{55}$ Entrevista concedida a William Robson Cordeiro em janeiro de 2018. 


\section{tïfolha}

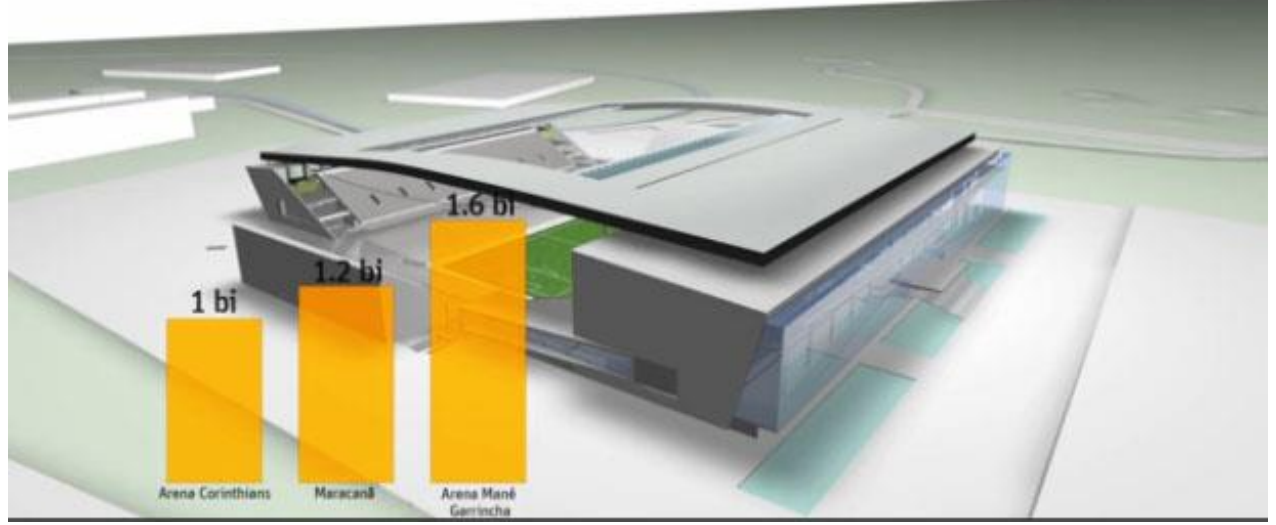

Figura 6. Videográfico em 3D da Folha de São Paulo sobre o estádio Itaquerão. Fonte: https://bit.ly/2QIEtea

Podemos dizer que esta infografia é composta de infogramas de caráter hipermidiático, que complementam a informação, tais como áudio com curiosidades e um gráfico em barras que serviu para comparar o Itaquerão com outros estádios da Copa e as camadas do estádio em 3D. O usuário é levado a um grau de imersão baixo, sem interatividade, visto tratar-se de um vídeo (embora os newsgames ofertem melhor experiência). O seu olhar é direcionado a uma viagem arquitetônica com possibilidade bem mais amplas que uma fotografia ou um simples vídeo não alcançariam.

\section{Considerações}

Esta exposição e estes exemplos extraídos de periódicos estadunidenses e brasileiros se configura como um exercício importante e ainda embrionário para a construção de um conceito dentro dos estudos que envolvem a visualização sintética e a infografia aplicadas ao jornalismo. Não é uma tarefa fácil por observar que a delimitação exata da fronteira entre o terceiro estágio evolutivo da infografia e esta atual proposta não se apresenta tão claramente. Porém este exercício é sobremodo pertinente para que passemos a olhar para as produções expressivas mais complexas e/ou imersivas no ambiente 
jornalístico e as novas tecnologias e linguagens que servem para contar histórias.

As fronteiras de onde começa a hiperinfografia sugerem ser definidas cronologicamente (nesta década de 2010), tecnicamente (com o surgimento de novos softwares, pós-Flash, banda larga mais acessível que possibilitou rodar infográficos mais "pesados", bem como os dispositivos mais modernos com maior capacidade de memória e processamento), ou hipermidiaticamente (produções mais complexas). Esta é uma etapa a ser considerada em estudos posteriores, dos quais caminhamos em nível de doutorado na Universidade Federal de Santa Catarina (UFSC), Brasil, e sob coorientação do professor Valero Sancho, na Universitat Autònoma de Barcelona (UAB).

O debruçamento vem exigindo um acompanhamento sistemático tanto do comportamento da infografia na hipermídia, quanto nas formas de produção nos periódicos - que dispensam ainda poucas peças neste quesito por uma explicação plausível: são infografias mais custosas que demandam profissionais de áreas diversas como o jornalismo, computação e design, por exemplo. Os levantamentos anteriores sobre os estágios da infografia facilitam o percurso e a compreensão destas fronteiras.

Procuramos, assim estabelecer três caminhos iniciais que consideramos importantes para entender este fenômeno: o primeiro foi delimitar o contexto onde a hiperinfografia se inclui, ou seja, o jornalismo pósindustrial ou de nova era. Este campo pressupõe novas formas de produção, novos formatos, de práticas jornalísticas, de consumo e de narrativas. O segundo ponto demarca os já citados estágios evolutivos da infografia no jornalismo. Os estudos acadêmicos até então trabalharam em três deles. Este artigo ousou adentrar em quarto momento, em que novas experimentações hipermidiáticas são possíveis. Este quarto ponto, assim como o terceiro, move-se na dinâmica do universo online. E, por fim, o terceiro ponto são as novas narrativas, as novas formas de contar as novidades, as notícias, princípio básico do jornalismo. As novas formas de linguagens se manifestam no jornalismo online, como a hiperinfografia, e instigam atenção especial. 
Ao tratar desta temática é importante sempre trazer os aspectos que envolvem a visualização e a visualidade, importantes para compreender os elementos infográficos. Se atualmente muito se fala em visualização de dados e jornalismo de dados, no fundo está intrínseca o envolvimento da infografia como forma de transmissão destes dados. A diferença está em seu caráter. Enquanto a visualização tem uma gama de informações em estado bruto que necessitam decupagem e orientação, o que requer especialização para o seu entendimento, a visualidade é a triagem com apresentação vistosa.

Os modelos de natureza imersiva, ubicativa, 3D, 4D, newsgames, ultrapassam os paradigmas clássicos da infografia definidos como comparativo, os fluxogramas, a "realid dibuja", as micofotografias, a imagem aumentada e as anamorfoses, entre outros, profundamente utilizados pelo jornalismo impresso e online, sem, é claro, desvincularse deles. Ou seja, a hiperfinfografia se sustenta nas características básicas que definem este gênero infográfico.

O caminho está aberto e na intensidade das transformações de formatos, é provável que a infografia alcance estágios que hoje não podemos prever. Assim, como não podemos prever como se comportará o jornalismo pós-industrial. Ao estabelecermos esta proposta, entendermos que a hiperinfografia não se tornará um conceito defasado, pois intenta abarcar as infografia complexas de hoje e do porvir. No entanto, como as fronteiras da internet são surpreendentes, um olhar atento às transformações nos formatos e na visualização sintética deve tornar-se prática constante.

\section{Bibliografia}

Amaral, Ricardo Castilhos Gomes (2010): Infográfico jornalístico de terceira geração: análise do uso da multimidialidade na infografia. Dissertação. Florianópolis (Brasil): Universidade Federal De Santa Catarina

Anderson, C. W., Bell, Emily, Shirky, Clay (2013): Jornalismo pósindustrial: adaptação aos novos tempos. Revista de jornalismo, abriljunho. São Paulo: Editora ESPM, pp.30-89 
Bogost, Ian, Ferrari, Simon, Schweizer, Bobby (2010): Newsgames: journalism at play. Cambridge: MIT Press

Cairo, Alberto (2011). El arte funcional - Infografía y visualización de información. Madrid. Alamut

Contreras, Fernando (2000): Nuevas fronteras de la infografía. Análisis de la imagen por ordenador. Sevilla (Espanha): Mergablum

Cordeiro, William Robson \& Costa, Luciano (2016): Jornalismo imersivo: perspectivas para os novos formatos. Revista leituras do jornalismo. Ano 3. V. 2 (6), julho-dezembro. Bauru (Brasil): UNESP, pp. 99-116.

Longhi, Raquel Ritter (2014): O turning point da grande reportagem multimídia. Revista famecos. V. 21 (3), setembro-dezembro. Porto alegre (Brasil), pp. 897-917

Longhi, Raquel Ritter (2015): A grande reportagem multimídia como gênero expressivo no ciberjornalismo. 6o simpósio internacional de ciberjornalismo. Campo Grande (Brasil): Anais

Longhi, Raquel Ritter; Cordeiro, William Robson (2018): No jornalismo imersivo, o infográfico é hiper. Revista líbero. São Paulo.

Marín-Ochoa, Beatriz Elena (2009): La infografia digital - una nueva forma de comunicación. Tese. Barcelona: Universidade Autônoma

Rodrigues, Adriana Alves (2009): Infografia interativa em base de dados no jornalismo digital. Dissertação. Salvador (Barsil): Universidade Federal da Bahia

Teixeira, Tattiana (2008): Que beleza! O infográfico e o jornalismo informativo. In: Felippi, Ãngela, Soster, Demétrio de Azeredo, Piccinin, Fabiana (org.). Edição de imagens em jornalismo. Santa Cruz do Sul (Brasil): Edunisc, pp. 162-183 
Teixeira, Tattiana (2010). Infografia e jornalismo - conceito, análises e perspectivas. Salvador (Brasil): Edufba.

Valero Sancho, José Luis (2001): La infografia: técnicas, análisis y usos periodísticos. Barcelona: Universidade Autônoma

Valero Sancho, José Luis (2012): Infografia digital. La visualización sintética. Barcelona: Bosch.

Vidal, Francisco José Morera (2017). Aproximación a la infografia como comunicación efectiva. Tesis doctoral. Bellaterra (Espanha): Universidade Autônoma de Barcelona 


\title{
La infografía didáctica en el OCW de la Universidad del País Vasco (2013-2018)
}

\author{
Aitor Castañeda ( $\mathrm{G}$ ). Departamento de Comunicación \\ Audiovisual y Publicidad. EHU, España. \\ aitor.castaneda@ehu.eus
}

Resumen: La presente investigación establece una comparativa con otra de similar planteamiento realizada en el 2013 por el mismo autor, en la que se analizaban tanto la cantidad como las generaciones de las infografías didácticas alojadas por el profesorado en la plataforma de Open Course Ware (OCW) de la Universidad del País Vasco/Euskal Herriko Unibertsitatea o EHU (España) durante los cursos 2008-2012. Siguiendo el mismo método sumatorio de recolección y análisis generacional utilizado en el estudio previo, se comparan la cantidad de infografías encontradas con otros tipos de imágenes orientadas a la enseñanza durante los cursos 2013-2018 subidas a la plataforma, pudiendo apreciar así su proporción respecto al resto de imágenes que la comunidad docente utiliza en el OCW, así como el creciente uso de la infografía en esta plataforma y su producción cada vez más autónoma por parte del profesorado.

Palabras clave. Infografía, infografía didáctica, imagen didáctica, educación, eLearning. 


\section{Introducción. Objetivos y definiciones}

T B BREVE investigación que aquí se presenta establece una L comparativa con el estudio presentado por el mismo autor en la quinta edición del Congreso Internacional Latina de Comunicación Social de la Universidad de La Laguna -Tenerife, España-, celebrado en la ciudad homónima en diciembre de 2013, y cuyas actas están disponibles en la red (Herrero et al. [coord.] 2013).

En aquel congreso, el autor propuso un análisis de las infografías didácticas alojadas en la plataforma de Open Course $W$ are ${ }^{56}$-en adelante OCW- de la Universidad del País Vasco -en lengua vasca y oficialmente Euskal Herriko Unibertsitatea, y en adelante EHU-, en cuya Facultad de Comunicación trabaja, obteniendo como resultado un uso testimonial de la infografía en los materiales de enseñanza alojados en dicha plataforma en comparación con otras imágenes de uso didáctico halladas en la misma (Castañeda, 2013: 23-24). Entonces se extrajeron un total de 1442 imágenes, distribuidas durante cinco años y 32 cursos, de las cuales menos de un 1\% eran infografías.

Cantidad de imágenes por tipologías (\%)

2008-2012

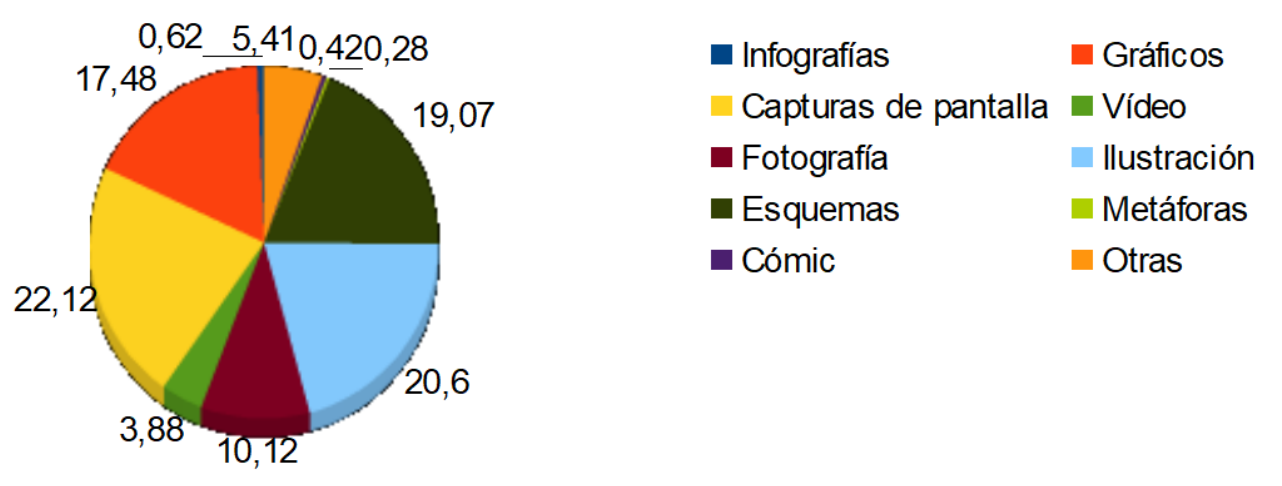

Gráfico 1. Fuente: Castañeda, 2013: 22

Habida cuenta de las posibilidades visuales y didácticas de la infografía para el campo de la educación, y dados los escasos resultados recogidos en la investigación de hace años, se pretende ahora volver sobre la

\footnotetext{
${ }^{56}$ La traducción castellana del término correspondería a "intercambio de cursos abiertos". Como se definirá más adelante, se habla de cursos universitarios en línea, de alcance abierto para quienes se inscriben a los mismos.
} 
misma plataforma OCW-EHU, cuyo funcionamiento y características se explicarán en las siguientes líneas, y establecer una comparativa respecto al estudio del 2013, analizando así la evolución en el uso de las imágenes de fin didáctico en esta sustanciosa plataforma de educación a distancia.

Si entonces se estudiaron los contenidos de un total de cinco cursos (2008-2012), el momento presente hace posible que se estudien otros cinco (2013-2018), cuadrando así la comparativa actual con la de ahora.

\subsection{Qué es un $\mathrm{OCW}$}

Bajo las siglas OCW se entienden las plataformas web de aprendizaje a distancia a través de Internet, también conocido como electronic learning o e-learning. Dichas plataformas sirven para alojar materiales didácticos dentro de cursos reglados a través de la red, favoreciendo así la formación a distancia de quienes se inscriben a los mismos. La que concierne la universidad en cuestión se aloja desde el 2008 en la dirección http://ocw.ehu.eus, y ya en su página de inicio ofrece una muy precisa definición de lo que es un OCW:

"Open Course Ware (OCW) es un proyecto que surgió en el Instituto Tecnológico de Massachusetts [...] en 2001, donde el objetivo principal era proporcionar acceso libre a los contenidos de sus asignaturas, de forma abierta [...]. Open Course Ware no es un campus virtual, sino un lugar para la publicación de materiales docentes."

Así pues, el OCW-EHU permite al profesorado darse de alta en el mismo y crear cursos de aprendizaje abierto, bajo las licencias Copyleft o Creative Commons, si bien en algún caso la inscripción al curso requiere del cumplimiento de algún requisito técnico para acceder con contraseña.

En lo referente a la organización de los contenidos del OCW-EHU, ésta no ha variado desde el 2012. Los cursos están agrupados por años, desde el 2008 hasta el 2017. Cada año clasifica sus cursos en las siguientes materias: 
- Ciencias de la Salud.

- Ciencias.

- Arte y Humanidades.

- Ciencias Sociales y Jurídicas.

- Ingeniería y Arquitectura.

Tanto en el caso del estudio del 2013 como en el presente, se ha escogido el bloque de Ciencias Sociales y Jurídicas, en tanto que quien los lleva a cabo proviene del Departamento de Comunicación Audiovisual y Publicidad ${ }^{57}$ de la Facultad de Ciencias Sociales y de la Comunicación de la EHU, siendo a la vez el presente monográfico perteneciente a dicha rama del conocimiento.

En todos los cursos se alojan documentos que las y los docentes suben a los mismos, o también información publicada a modo de entrada de blog o página. Los documentos pueden ir desde archivos PDF hasta links directos a determinados sitios. Todo lo alojado en los cursos se halla organizado en apartados, no idénticos en todos los cursos, pero sí con una estructura común, que puede ejemplificarse del siguiente modo:

- La guía docente, que contiene información sobre en qué consiste el curso, calendario lectivo y objetivos de aprendizaje.

- Material de estudio, con documentos que forman el corpus del curso: temas de estudio, vídeos, infografías, presentaciones, etc.

- Ejercicios y prácticas, con un apartado específico para su envío en línea.

- Otros recursos con material complementario al de estudio: enlaces a artículos, capítulos de libros, vídeos, etc.

- Procedimientos de autoevaluación para el seguimiento particular del proceso de estudio llevado a cabo el/la alumna/o.

- Bibliografía, con referencias a los contenidos académicos.

- Fichas con el perfil de las y los docentes.

${ }^{57}$ Más información sobre el Departamento y sus líneas de investigación en https://www.ehu.eus/es/web/cyp/hasiera (recuperado el 3 de junio de 2018). 


\subsection{Infografía e imagen didáctica}

Volviendo al objeto de estudio que se pretende analizar en el OCWEHU, se definirá a continuación qué es la infografía -o infográfico- y qué interés comporta en el campo de la didáctica y del aprendizaje.

La infografía fue definida por Castañeda en el 2013 desde la óptica de la enseñanza y la didáctica, apoyándose en las informaciones de Reinhardt, quien la entiende como "un conjunto de estructuras enunciativas de característica textual e iconográfica que expresan un contenido referente a un acontecimiento particular transformándolo en un saber público" (2010: 135). Se dirá entonces que se está ante un producto comunicativo gráfico, que combina otros elementos simbólico-icónicos y texto, con la intención de explicar una materia concreta.

Para llegar sin embargo a esa conclusión, debe partirse de otras aún más concretas, que dan a entender lo que es en sí la infografía, para aplicar después la definición al ámbito de la enseñanza -universitaria o no-. Así las cosas, se parte de que la infografía es una representación diagrámica de datos (Cairo, 2008: 21), siendo el diagrama un dibujo o representación gráfica en el que se muestran las relaciones entre diferentes partes de un sistema. Las formas simbólicas e icónicas de las que hace uso van acompañadas de texto, siendo posible añadirles materiales auditivos si éstas son digitales (Valero, 2001: 201).

¿Qué aportan sin embargo las infografías de cara al proceso de aprendizaje o didáctica? La respuesta se halla en la eficacia de su lenguaje multimedia. Lo primero es comprender el peso de la imagen gráfica en el mundo actual, en el que esa iconosfera que invade al individuo obliga a éste a adaptar sus coordenadas psicológicas, siendo así que el proceso de aprendizaje de un niño está en estos momentos estrechamente ligado a la lectura y comprensión de las imágenes, y la educación del siglo XXI debe asumir también esta realidad (Santos Guerra, 1984: 16). Así, y volviendo a la definición que se aporta aquí de la infografía, al ser ésta una representación diagrámica que combina en sí el lenguaje gráfico y textual $-\mathrm{y}$ en ocasiones auditivo- cabe entender que constituyan un recurso cada vez más utilizado en las aulas (Aguaded y Martínez-Salanova, 1999: "Seguir una noticia o situación 
significativa", pár.16), en tanto que el propio proceso natural de aprendizaje del ser humano es en sí multimediático.

Let's assume that humans have two information-processing systems - one for verbal material and one for visual material (...). The rationale for multimedia presentations -that is, presenting material in words and pictures - is that it takes advantage of the full capacity of humans for processing information. (Mayer, 2005: 4)

Evidentemente, y tal como se ha apreciado en la clasificación del Gráfico 1, existen diversas imágenes gráficas que resultan útiles de cara al proceso de memorización y aprendizaje de datos, que para determinados casos serán más o menos adecuadas que una infografía. Una imagen será pues didáctica cuando su producción haya derivado de cierta voluntad de convicción y deseo de enseñar y transmitir una información de cara a su aprendizaje. Con esto, toda imagen puede, en un contexto determinado, cumplir una función didáctica. Pero hay otras que nacen ya para serlo, como sea el caso de los los esquemas, diagramas, mapas conceptuales, etc. (Costa y Moles, 1991: 41-42).

Para el caso que aquí nos atañe, existen otras imágenes didácticamente útiles que se definen a continuación. Todas ellas fueron encontradas en el análisis del 2013 y en el presente, a saber: capturas de pantalla, cómics, fotografías, gráficos, ilustraciones, metáforas visuales y vídeos. Cabe destacar que una infografía puede contener todas las anteriores.

Las capturas de pantalla no tienen en sí -al menos en este estudio- más objetivo que el de mostrar la interfaz de ciertas aplicaciones informáticas para guiar visualmente al estudiante. Es por ejemplo el caso del curso del 2013 "Modelos de ecuaciones simultaneas con aplicaciones en Grett ${ }^{58 "}$, en cuyo archivo "Ejemplo empírico I con

\footnotetext{
${ }^{58}$ Desde aquí en adelante, para todos los cursos del OCW-EHU a los que se haga referencia se añadirá como nota al pie la localización web de los mismos, obviando por largura la URL "https://ocw.ehu.eus/course" que el lector debe teclear previamente para acceder a los mismos. Así, si el curso "Modelos de ecuaciones" se halla en el enlace completo de "https://ocw.ehu.eus/course/view.php?id=227", solo se indicará "view.php?id=227".
} 
gretl" recoge hasta seis capturas para mostrar al alumno el funcionamiento del software en cuestión.

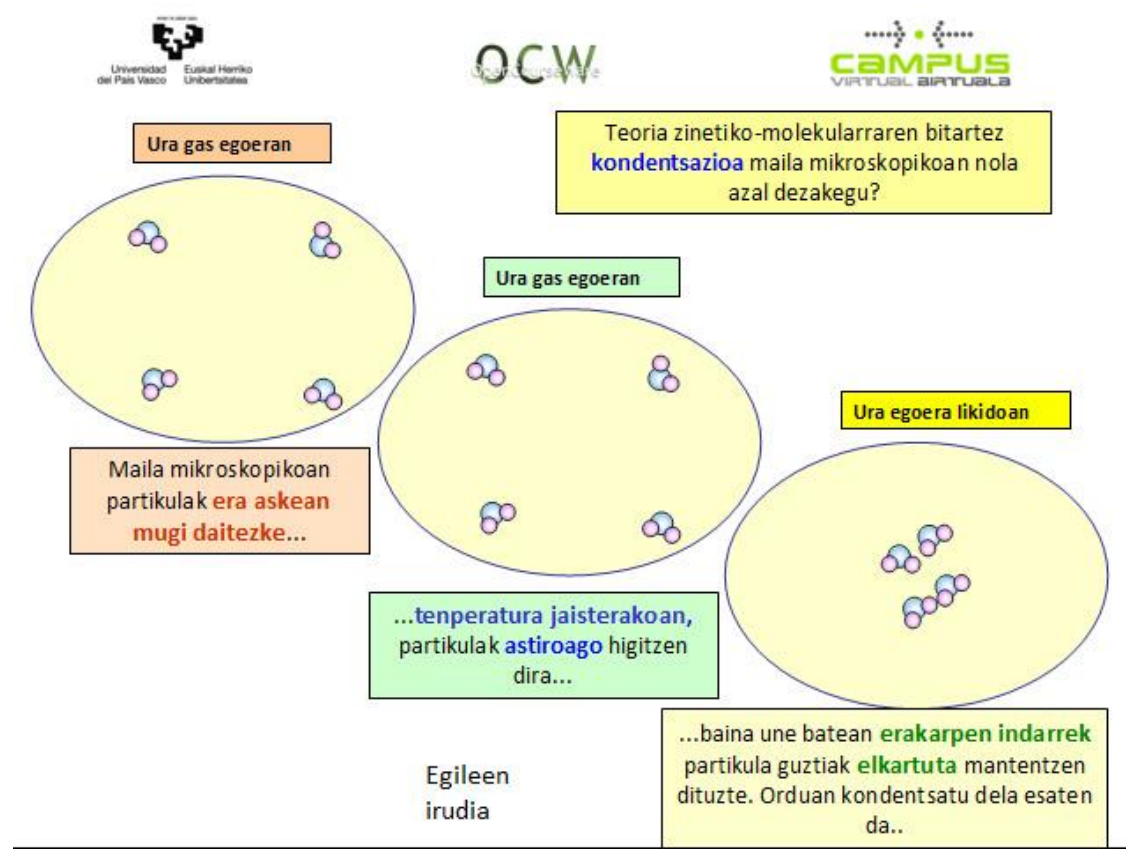

Ejemplo 1: Infografía animada que explica la condensación. Fuente: Aguirrezabalaga et al. (view.php?id=7317).

En lo que refiere al cómic, éste es definido por los especialistas Gasca y Gubern como "medio escripto-icónico basado en la narración mediante secuencias de imágenes fijas consecutivas que pueden integrar en su seno textos literarios" (1991: 10). Es así que el cómic resulta, al igual que la infografía, un material multimediático al integrar un componente icónico y otro literario y que resulta útil de cara al aprendizaje de contenidos (Castañeda y Pineda-Martínez, 2014: 2), aunque de lo que aquí se entiende por cómic se reduce a viñetas que ciertos docentes incluyen en sus materiales del OCW para bien amenizar sus contenidos, o bien para ilustrar alguna idea determinada que explican en los mismos. La viñeta de cómic, entendida según los autores que preceden, "delimita una porción de espacio en el que se representa bidimensionalmente, mediante el dibujo, un espacio ficticio, en cuyo interior acontece una acción de duración variable" (Gasca y Gubern, 1991: 12). 


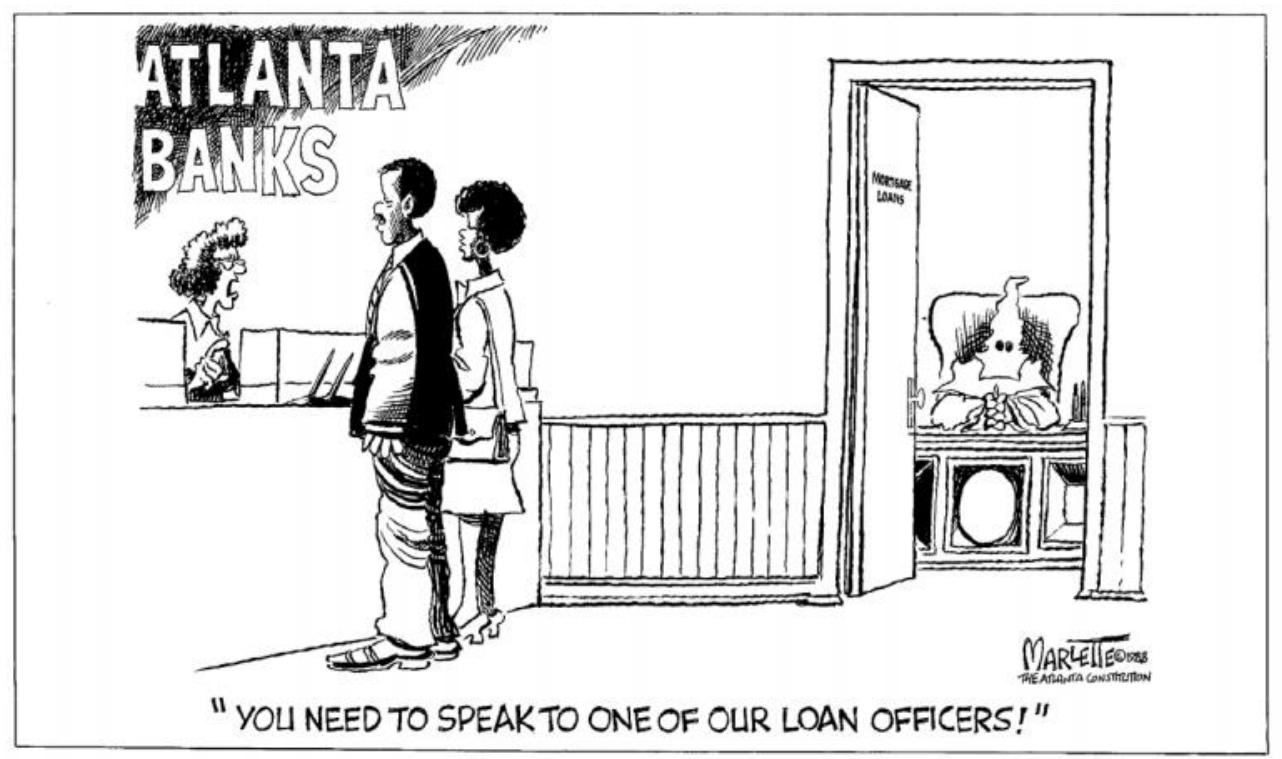

Ejemplo 2: Viñeta de cómic didáctico en archivo del OCW-EHU. Fuente: https://goo.gl/s8KpBT

La fotografía se entiende aquí como una imagen estática obtenida a partir del registro de la acción de la luz por un dispositivo fotosensible, que en este caso es siempre digital. Ilustran aquello de lo que se habla en los contenidos, cosa que también puede hacerse a través de dibujos explicativos o decorativos que complementan a los textos, es decir, de ilustraciones (Costa y Moles, 1991: 64). Por otra parte, cuando estas ilustraciones se organizan en torno a una estructura gráfica que utiliza la forma y/o elementos icónicos de un objeto, artefacto, actividad o historia reconocibles para el observador hablaremos de metáforas visuales, es decir, un tipo de imagen que pretende organizar un contenido informativo o didáctico y utilizar las asociaciones con la metáfora para transmitir un significado (Eppler, 2006: 203), siendo la metáfora la identificación de algo real con algo imaginario o evocado (Romera, s/f).

Por su parte, los gráficos se entenderán aquí como representaciones visuales por medio de símbolos que ilustran la relación entre diversas variables de un objeto concreto. Así, permiten apreciar la evolución de dichas variables, relacionar entre sí ciertos aspectos de las mismas, etc. A menudo forman la parte nuclear de las infografías comparativas para más detalles sobre las mismas, se recomienda leer a Valero (2001)-. 


\section{Qué se entiende por ASC}

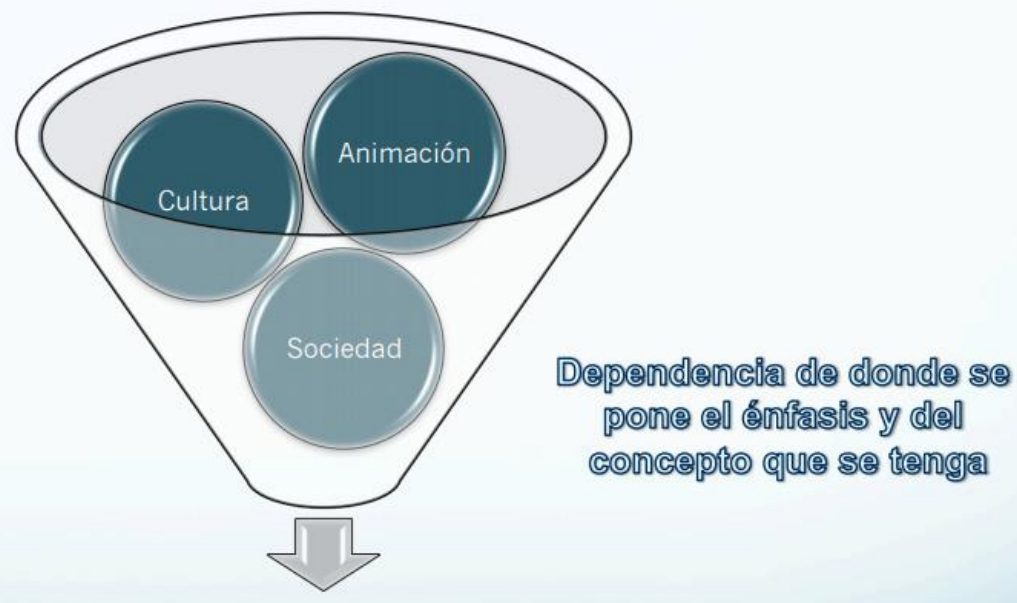

Animación sociocultural

Ejemplo 3: Metáfora visual en archivo del OCW-EHU.

Fuente: Alonso Olea, M. J. et al. (https://goo.gl/p7XgRp)

Por fin, y desde el punto de vista didáctico, se considerará al vídeo un medio audiovisual y de información afín a la televisión, e incluso una extensión de la misma (Romera y Lorca, 1990: pár.31). Hoy circulan frecuentemente por la red a través de plataformas como Youtube o Vimeo, y son muy apreciados en educación como herramienta para mostrar información al alumnado. Es por ejemplo el caso del curso "PLE: Construyendo el conocimiento en la $\operatorname{red}^{59 "}$ (2016) donde el profesor Carlos M. Castaño y otros seis docentes crean sus propios vídeos de presentación para los cinco bloques temáticos del curso, además de otros tantos en su material de estudio.

\subsection{Generaciones de la infografía}

Como ya se anunciaba en el estudio del 2013 (Castañeda, 2013: 11-12), la infografía ha dependido desde los inicios de su historia del material tecnológico disponible para su desarrollo, tal como resulta evidente en la creación y difusión de la información, ora escrita, ora iconográfica. Con todo, y en base a lo concluido por Cavalcanti en su estudio del 2011 (6-10), se distinguen a lo largo de su historia cuatro generaciones de infográficos, ligados evidentemente a su uso en prensa y medios de

${ }^{59}$ view.php?id $=424$ 
comunicación, que se distinguen por la capacidad de interacción con el lector/usuario, rasgo esencial, como se ha dicho, de su capacidad multimediática en la enseñanza. Dichas generaciones no corresponden forzosamente a periodos históricos concretos, aunque sí exista cierta correlación entre una mayor pobreza de medios en las generaciones precedentes que en las últimas, lo que provoca que en las primeras generaciones la interactividad con el usuario sea menor. No obstante, disponiendo hoy día de medios tecnológicos suficientes para una potente interacción, diversos infográficos se enmarcan aún en las primeras generaciones dependiendo de su uso.

Así, una primera generación -en adelante $1^{\mathrm{a} g}$ - de infografías respondería a aquellas cuyo lenguaje fuese lineal, sin ninguna innovación respecto al material impreso, y que no permitiesen interacción ninguna con el lector, siguiendo el planteamiento de remitente, mensaje, receptor. En cambio, las de segunda generación $\left(2^{\mathrm{a}} \mathrm{g}\right)$ permitirían incluir ya algunos elementos auditivos, siendo creadas con programas de Office como Power Point -de ahí que Cavalcanti también las denomine "generación de slideshows"- (2011: 7). Una $3^{\mathrm{a}} \mathrm{g}-$ "newsgames" - permitiría la creación infográfica para web, planteando estas como material multimediático que integra sonido, fotografía, gráficos, etcétera, y en una $4^{\mathrm{a}} \mathrm{g}$ sería posible la personalización de contenido y la integración en servicios web. Como es obvio, la apuesta por la educación a distancia o e-learning se enfoca más hacia esta última generación de infografías.

\section{Objetivos y metodología}

Como se ha especificado, el objetivo principal de este estudio es establecer una comparativa entre el estudio presentado en el 2013 con la presencia de la infografía en el OCW-EHU de los últimos cinco años. Los objetivos específicos del 2013, que se enuncian a continuación, eran los que siguen:

1. Cuantificar el número de infografías didácticas en los cursos de Ciencias Sociales y Jurídicas del OCW-EHU.

2. Clasificar las infografías identificadas según sus generaciones. 
3. Comparar la cantidad de infografías didácticas con la de otras imágenes de fines educativos en los mencionados cursos de la plataforma.

4. Observar la evolución del uso de infografías didácticas por años en comparación con el de otras imágenes de fines educativos en los mencionados cursos de la plataforma.

5. Observar si las infografías estudiadas son de elaboración propia o ajena por parte del profesorado creador de cada curso en cuestión.

Habiendo seguido aquéllos, se mantienen los mismos en la presente estudiando el intervalo anual del 2013 al 2017, estableciendo una comparativa con los resultados de la investigación que precedió. De la misma manera se mantiene el método, que se recuerda, consiste en la contabilización y clasificación de las imágenes extraídas de los cursos del OCW-EHU, atendiendo a los siguientes criterios, también seguidos en la investigación del 2013:

- Se analizan solo los contenidos alojados en el apartado "Materiales de estudio" de cada curso -Ikasteko materialak en vasco y Course materials o Lectures en inglés-, pues, aunque todos los cursos distribuyen sus contenidos en apartados más o menos iguales es éste el que todos tienen exactamente en común y donde se encuentran los documentos troncales que emplea el estudiantado.

- Cuando se intercepta un mismo curso duplicado en dos o más idiomas, se contabilizaban todos ellos como uno solo, analizando solamente uno de ellos. Tal como en la investigación del 2013, se ha denominado a estos cursos 'acoplados'.

- Se analizan, dentro de los 'materiales de estudio', las imágenes de aquellos documentos que el profesorado hubiese creado de manera propia para su materia. De este modo, se evitaría, por una parte, incluir en la muestra documentos excesivamente largos -como monografías completas- o analizar materiales que segundos hubiesen creado con otras intenciones ajenas a la explicación de la materia en cuestión. 
Como hace cinco años, existen imágenes que podrían haber sido clasificadas en una o más categorías de imágenes, que son las que quedan establecidas en el apartado 1.3 de esta investigación. Había también algunas que se repetían dentro de los mismos archivos una y otra vez, como meros elementos decorativos. Así las cosas, cuando una imagen se repetía en el mismo documento, ésta solo se registraba una vez. Con todo:

- Se recogieron infografías, teniendo en cuenta cómo se las ha definido en el presente estudio.

- Dentro de la categoría 'gráfico' se englobaron histogramas y diagramas de todo tipo.

- Se tuvieron en cuenta las capturas de pantalla tal como quedan definidas en el epígrafe 1.3 del presente estudio, así como los vídeos alojados o embebidos en los archivos que se estudian.

- Para las fotografías, se tienen en cuenta las imágenes fotográficas y fotogramas de películas. Se ha incluido aquí estos últimos porque, atendiendo a la producción cinematográfica, todo fotograma es en sí una fotografía.

- Toda imagen icónica dibujada a mano o creada por ordenador mediante técnicas propias de la disciplina artística de la ilustración son, en este estudio, ilustraciones. Se engloban las siguientes: dibujos, pinturas, gifs animados e imágenes predeterminadas de Office.

- Se incluyen también metáforas visuales tal como las hemos definido en este estudio.

- En lo que refiere a los esquemas, y aunque de que los siguientes no coinciden precisamente con la definición de tales aportada en el punto 1.3, se han entendido también para esta categoría los mapas mentales y conceptuales, diagramas conceptuales, esquemas ilustrados y nubes de conceptos.

- Para el cómic, se tienen en cuenta las tiras cómicas y secuencias narrativas ilustradas.

- Se ha incluido un apartado de "Otras" para aquellas imágenes no clasificables en las categorías anteriores, como logotipos, montajes o collages digitales con función estética, radiografías, fotocopias de manuscritos, etc. 
A su vez:

- Todas las imágenes que se encuentran bajo el mismo pie de imagen son consideradas una sola.

- No se consideran imágenes aquellas que figuren en las portadas de los documentos, pues no forman parte directa del contenido didáctico o explicativo.

- En el caso de las presentaciones Power Point, no se consideran imágenes las plantillas de las presentaciones.

\section{Resultados y conclusiones}

Si en el estudio del 2013 se obtuvo un total de 1442 imágenes didácticas distribuidas en 32 cursos - con cinco de ellos acoplados, lo que elevaba su cantidad a 37-, en el presente se han colectado 2487 , esto es, un $26^{\prime} 60 \%$ más que hace cinco años, distribuidas en 69 cursos -76 con acoplados-.

Número de cursos por años analizados

\begin{tabular}{lllc} 
Año & \multicolumn{2}{c}{$\mathbf{N}^{\mathbf{0}}$ Cursos } & $\mathbf{N}^{\mathbf{o}}$ acoplados Total \\
2013 & 30 & 3 & 33 \\
2014 & 11 & 3 & 14 \\
2015 & 11 & 0 & 11 \\
2016 & 12 & 1 & 13 \\
2017 & 5 & 0 & 16 \\
\hline Totales & $\mathbf{6 9}$ & $\mathbf{7}$ & $\mathbf{7 6}$ \\
& & & Tabla 1. Fuente: Propia
\end{tabular}

El incremento tanto en número de imágenes como de cursos es considerable, si bien, el cálculo medio que se obtiene al dividir la cantidad total de imágenes entre el número de cursos sin acoplados arroja cifras que indican que durante el periodo 2008-2012 la cantidad de imágenes por curso era de 38'97, mientras que en el actual es de 36'04, lo que no constituye una enorme diferencia, pero sí evidencia cierta merma en términos medios.

Lo que resulta innegable es el elevado incremento en el uso de la infografía, que, si en el estudio precedente constituía un 0 ' $62 \%$ del total, esta vez la cifra asciende a un 9'65, multiplicando su cantidad casi por 
diez. Se trata así del tipo de imagen que más aumenta, seguida por los gráficos $\left(+43^{\prime} 12 \%\right)$, las metáforas visuales $(+42,86 \%)$ y los esquemas $(+42,23 \%)$ subsecuentemente. También aumentan las demás, salvo el cómic, que disminuye drásticamente en un $71^{\prime} 43 \%$; los vídeos, en un 51'35; las ilustraciones, un 26'65 y el heterogéneo grupo de otras imágenes, que disminuyen casi un $5 \%$. Si en el periodo estudiado en el 2013 las imágenes más cuantiosas eran las capturas de pantalla (319) las ilustraciones (297) y los esquemas (275), esta vez lo serán estos últimos (677), los gráficos (634) y de nuevo las capturas (466), creciendo enormemente los gráficos y destronándose las ilustraciones, probablemente por el poder de éstos de mostrar diversas variables y relacionarlas visualmente entre sí. La infografía, aun habiendo crecido, sigue estando en los últimos puestos.

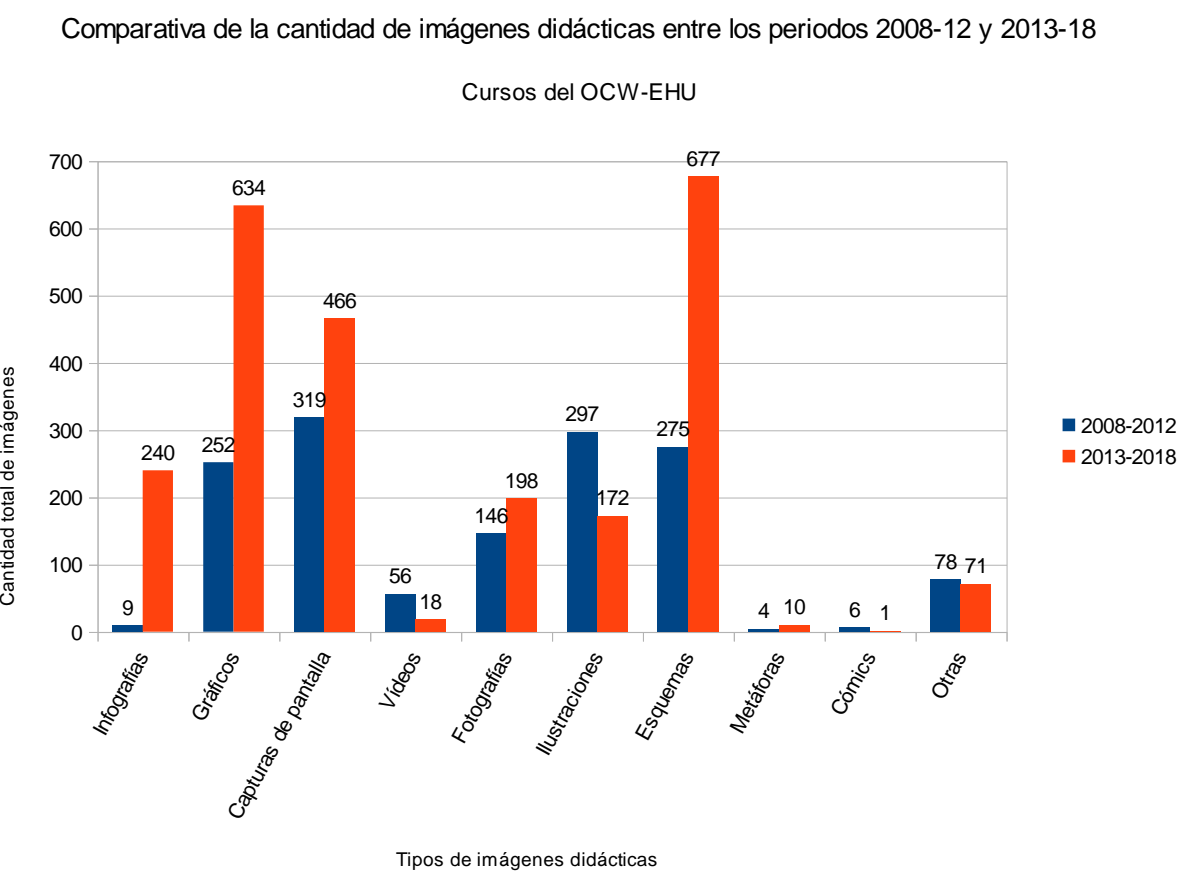

Gráfico 2. Fuente: Propia.

Hay que mencionar sin embargo que la cantidad de infografías por cursos y años es muy desigual, pues si bien su número oscila entre el diez y treinta durante todos los años, salvo en 2014 cuya cantidad es cero, en 2015 es casi de 180, sin duda debido a su gran producción en el curso Natura zientriak lehen mailako ikasgelan ${ }^{60}-$ "Ciencias naturales en el aula de primer curso"-, que suma 173 infografías animadas

${ }^{60}$ view.php?id $=357$ 
producidas en dieciséis presentaciones Power Point por los docentes Aguirrezabalaga, Barrutia, Etxabe, Goienetxea, Otermin y Sanz, que merecen ser mencionados en este estudio.

Cantidad de infografías por año estudiado

OCW-EHU (periodo 2013-2017)

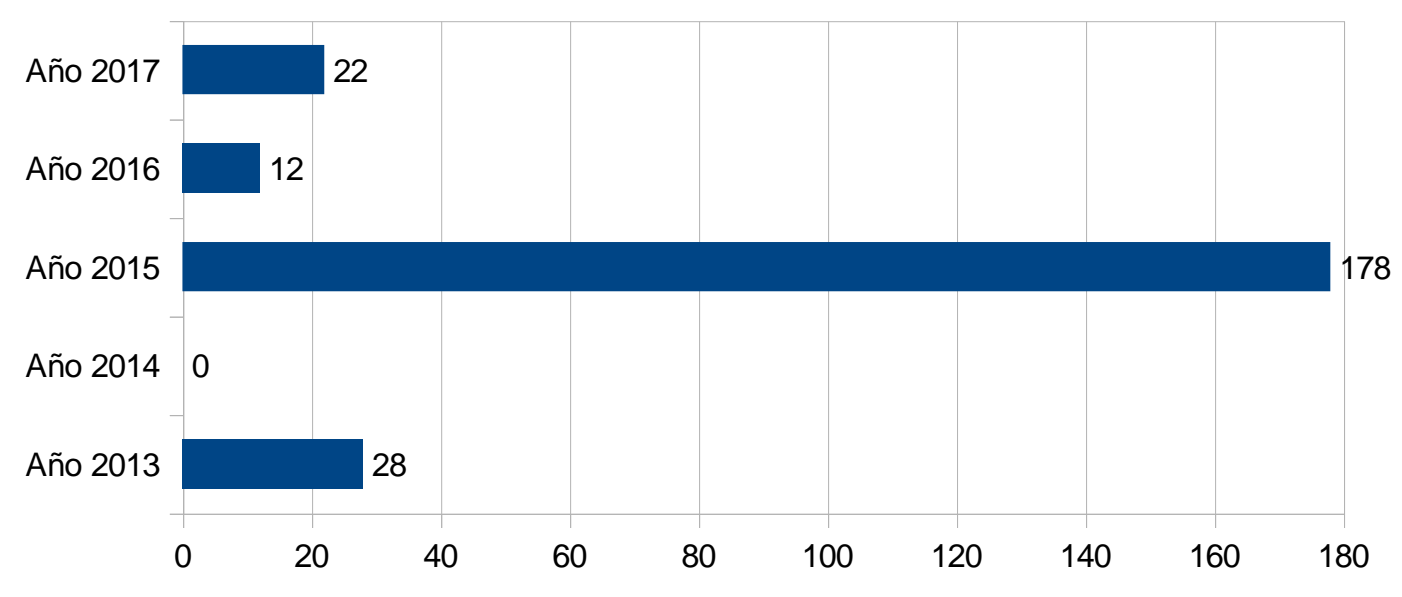

Gráfico 3. Fuente: Propia.

Todas las infografías colectadas, salvo las producidas por los mencionados seis autores, pertenecen a la $1^{\mathrm{a}} \mathrm{g}$, y estas últimas a la $2^{\mathrm{a}} \mathrm{g}$, quedando excluidas la $3^{\mathrm{a}} \mathrm{g}$ y la $4^{\mathrm{a}} \mathrm{g}$-en el estudio del 2013 , de las solo nueve infografías colectadas seis pertenecían a la $1^{\mathrm{a}} \mathrm{g}$, una a la $2^{\mathrm{a}} \mathrm{g}$ y dos a la $3^{\mathrm{a}} \mathrm{g}$-. Así, tanto en números absolutos como porcentuales se puede hablar de un importante incremento de las posibilidades interactivas, decreciendo las infografías de la $1^{\mathrm{a}} \mathrm{g}$ casi un $41 \%$ y creciendo las de la $2^{\mathrm{a}} \mathrm{g}$ un $63^{\prime} 06^{\circ} \%$. Lastimosamente ha desaparecido de la muestra todo rastro de infografía de $3^{\mathrm{a}} \mathrm{g}$, que sí existía en el 2013.

Cantidades absolutas y porcentuales de infografías en el OCW-EHU por periodos estudiados

\begin{tabular}{|c|c|c|c|c|c|}
\hline & BSOLU & TAS & POR & CENTUAL & \\
\hline & 008-2012 & & -2017 & 2008-2012 & 2013-2017 \\
\hline $1^{a} g$ & 6 & 62 & $66^{\prime} 67$ & $25^{\prime} 83$ & \\
\hline $2^{a} \mathrm{~g}$ & 1 & 178 & 11'11 & $74^{\prime} 17$ & \\
\hline$\underline{3^{a} g}$ & 2 & 0 & $22^{\prime} 22$ & 0 & \\
\hline 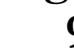 & & 40 & 100 & 100 & \\
\hline
\end{tabular}

Tabla 2. Fuente: Propia 
En lo que refiere a la elaboración de las infografías localizadas, si en el 2013 se halló solo una infografía de elaboración casi propia, en la presente investigación se identifica una importante mayoría -más del doble- de infografías realizadas por el propio profesorado, lo que no solo lleva a concluir el creciente interés por la misma, sino que además muestra el compromiso de parte profesorado por crearlas y adecuarlas a las necesidades del alumnado, aunque éstas sean más o menos imperfectas y generalmente creadas con Office o incluso a mano, como se ha identificado en algún caso.

Cantidad de infografías por elaboración y año Elaboración 20132014201520162017 Total

$\begin{array}{lllllll}\text { Propia } & 9 & 0 & 177 & 3 & 0 & \mathbf{1 8 9}\end{array}$

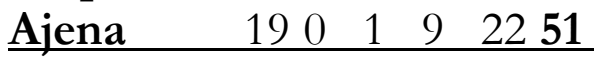

Total $\quad 280178 \quad 1222240$

Tabla 3. Fuente: Propia

Estos resultados dejan ver la más que notable evolución de hace cinco años hasta hoy, de tal manera que el incremento de producción, mejores técnicas interactivas y una mayor habilidad productiva de las y los profesores participantes en el OCW-EHU han producido una proliferación de infográficos en la plataforma, si bien hay que subrayar que no se trata, ni mucho menos, de un tipo de imagen didáctica mayoritariamente usado en el material de estudio. Sorprende asimismo que un mayor uso vaya acompañado de una mayor producción propia de infografías por el profesorado, que triplica el número de infografías propias por el de las ajenas, destacando sobre todo los autores del curso del 2015 sobre ciencias naturales en el aula (view.php?id=357). Asimismo, aunque ahora es mayoritaria la infografía de $2^{\mathrm{a}} \mathrm{g}$, casi todos los infográficos estudiados ofrecen aún muy pocas posibilidades interactivas, habiendo desaparecido las de $3^{\mathrm{a}} \mathrm{g}$ de la muestra. Aún y todo, la evolución es muy positiva, y probablemente en otros cinco años, y si la tendencia es similar, podrá apreciarse un mayor y mejor uso de infografías didácticas de $3^{\mathrm{a}} \mathrm{g}$ y $5^{\mathrm{a}} \mathrm{g}$. 


\section{Bibliografía}

Cairo, A. (2008). Infografía 2.0: visualización de información en prensa. Madrid: Alamut

Castañeda, A. (2013). "La infografía didáctica en la plataforma OCW de la Universidad del País Vasco. Cuantía y análisis del infográfico en comparación con otras imágenes didácticas en la plataforma", en Herrero, F. J. et al. (coord.). La sociedad ruido. Entre el dato y el grito. Libro de actas del V. Congreso Internacional Latina de Comunicación Social (3-5 de diciembre). La Laguna: Sociedad Latina de Comunicación Social. Recuperado el 28 de mayo de 2018 de

http://www.revistalatinacs.org/13SLCS/2013 actas/181 Castane da.pdf

Castañeda, A. y Pineda-Martínez, P. (2014). "El cómic didáctico en las webs de los parlamentos autonómicos españoles. Una aproximación descriptiva y mecanismos didácticos", en Herrero, F. J. et al. (coord.). La democracia no es un editorial. Patrones neoliberales en los medios de comunicación. Libro de actas del VI Congreso Internacional Latina de Comunicación Social (2-5 de diciembre). La Laguna: Sociedad Latina de Comunicación Social. Recuperado el 13 de junio de 2018 de http://www.revistalatinacs.org/14SLCS/2014 actas/007 Castane da.pdf

Cavalcanti, C. et al. (2011). "Infografia como alternativa para o ensino a distância". Hipertextus, 6. Recuperado el 24 de enero de 2013 en http://www.hipertextus.net/volume6/Hipertextus-Volume6Carolina-Cavalcanti-Bezerra Maria-Lucia-Serafim Laercia-MariaMedeiros.pdf

Costa, J. y Moles, A. (dir.) (1991). Imagen didáctica. Barcelona: CEAC.

Eppler, M. J. (2006). “A comparison between concept maps, mind maps, conceptual diagrams, and visual metaphors as complementary tools for knowledge construction and sharing". Information Visualization, 5, pp. 202-210. Recuperado el 13 de junio 
de 2018 de

http://www.alexandria.unisg.ch/Publikationen/54807.5.10.1057/ palgrave.ivs. 9500131

Gasca, L. y Gubern, R. (1991). El discurso del cómic. Madrid: Cátedra

Herrero, F. J. et al. (coord.) (2013). La sociedad ruido. Entre el dato y el grito. Libro de actas del V. Congreso Internacional Latina de Comunicación Social (3-5 de diciembre). La Laguna: Sociedad Latina de Comunicación Social. Recuperado el 28 de mayo de 2018 de http://www.revistalatinacs.org/13SLCS/2013 actas.html

Martínez-Salanova, E. (s/f). "La infografía, un instrumento para el análisis". In Aguaded, J. I. y Martínez-Salanova, E. (1999). El periódico en las aulas. Análisis, producción e investigación. Huelva: Comunicar. Recuperado el 29 de enero de 2013 de http://www.uhu.es/cine.educacion/periodico/12infografiaperiodi co.htm

Mayer, R. E. (ed.) (2005). "Chapter I: Introduction to Multimedia Learning", en The Cambridge Handbook of Multimedia Learning. Cambridge Handbooks in Psychology. Reino Unido: Cambridge University Press, 1-18. Recuperado el 11 de febrero de 2013, de http://assets.cambridge.org/97805218/38733/excerpt/978052183 $\underline{8733 \text { excerpt.pdf }}$

Reinhardt, N. (2010). "Infografía Didáctica: producción interdisciplinaria de infografías didácticas para la diversidad cultural". Centro de Estudios en Diseño y Comunicación, (31), 119-191. Recuperado el 23 de enero de 2013 de http://www.scielo.org.ar/scielo.php?pid=S1853$\underline{35232010000100003 \& \text { script }=\text { sci arttext }}$

Romera, Á. (s/f). Retórica. Manual de retórica y recursos estilísticos. Libro de notas. Recuperado el 16 de junio de 2018 de http://retorica.librodenotas.com/

Romera, J. y Lorca, J. A. (1990). "Reflexiones didácticas sobre las imágenes y las tecnologías". EDUTEC 99. Libro de actas del IV Congreso de Nuevas Tecnologías de la Información y de la 
Comunicación para la educación. Nuevas tecnologías en la formación flexible y a distancia. Recuperado el 28 de enero de 2013, de

http://gte2.uib.es/edutec/sites/default/files/congresos/edutec99 Lpaginas/97.html

Santos Guerra, M. A. (1984). Imagen y educación. Madrid: Anaya.

Valero, J. L. (2001). La infografía : técnicas, análisis y usos periodísticos. Barcelona: Universidad Autónoma

Valero, J. L. (2009). "La transmisión de conocimiento a través de la infografía digital”. Ámbitos, 18, 51-63. Recuperado el 3 de junio de 2018 de

https://ddd.uab.cat/pub/artpub/2009/116142/ambitos a2009n1 8p51.pdf 



\section{A \\ Los autores del libro}

Dr. AITOR CASTAÑEDA ZUMETA, aitor.castaneda@ehu.eus Doctor en Comunicación Social por la EHU. Máster en Comunicación y licenciado en Publicidad y Relaciones Públicas por la EHU. Técnico superior en ilustración y artes gráficas por la Escuela de Arte y Diseño I D A Arte de Vitoria-Gasteiz (España). Presenta en este libro un estudio de la infografía de los principales grupos informativos del País Vasco, región española de elevada cobertura periodística, y analiza la calidad de las infografías de los diarios de dichos grupos, que cubrieron el atentado terrorista del 17A en la ciudad de Barcelona, suceso de gran relevancia internacional. A su vez, propone otro estudio sobre la infografía didáctica en la plataforma $\mathrm{OCW}$ de la $\mathrm{EHU}$, de la que es profesor en la actualidad.

\section{JORDI CATALÀ DOMÍNGUEZ, jordicatalad@gmail.com}

Comunicador visual, diseñador gráfico, periodista. Historiador por la UB. Profesor asociado de la UAB, UVic y UPF, además de en los centros HEINA, Elisava y el Centro Universitario de Diseño de Barcelona. Imparte cursos de másteres, postgrados, y de formación continua -Tecnocampus y IL3 (UB)-. Creó el Departamento de Infografía de El Periódico de Catalunya, en donde fue redactor jefe de infografía, obteniendo cerca de doscientos premios nacionales e internacionales, entre ellos el de Mejor Diario Diseñado de Europa (2008). Especialista en infografía de empresa, Comunicación Visual, Creación de Contenidos Visuales y Visualización y Redes. Ha sido dos veces Jurado de los European Newspapers Award. 
HERNÁN FRANCO HIGUITA, hernandfranco@gmail.com

Diseñador gráfico de la UPB. Estudiante de la Maestría en Diseño y Creación Interactiva en la Universidad de Caldas, docente cátedra de la UPB.

\section{Dra. MARIANA LAPOLLI, marilapolli@gmail.com}

Licenciada en Comunicación Social, Publicidad y Propaganda. Máster, doctora y post-doctora en Medios de Conocimiento por el Programa de post-graduación por la UFSC. Realizó una estancia doctoral en el Departamento de Comunicación Audiovisual y de Publicidad de la Facultad de Ciencias de la Comunicación de la UAB. En el área de comunicación, ha realizado trabajos como redactora de publicidad y periodismo, asesora de imprenta y productora de programas de televisión. Posee publicaciones en las siguientes áreas: Cultura Visual, Narrativas, Infografía, Hipermedia, Nuevos Medios, Creatividad, etc. Entre sus publicaciones destacan los libros Publicidade na era Digital: um desafio para hoje (2008) e INFOGRAFLA na era da cultura visual? (2016). Es socia de la editorial Pandion, de la que es productora editorial, escritora y directora de creación. En el campo artístico, hace ballet clásico desde hace quince años en escuelas de Brasil y Francia (19862000). En el 2006 pasó a participar en la Oficina Permanente de Teatro del Departamento Artístico Cultural de la UFSC. Es integrante del grupo Pesquisa Teatro Novo, habiendo actuado en los siguientes espectáculos: Sonhos (2008), As Luas de Galileu Galilei (2009 a 2011), Hamlet in Quarto (2012 a 2014) y Luz em Einstein (2017). Está especializada en Cuerpo: danza, teatro y performance por el Centro de Artes y Educación Célia Helena en San Paulo.

\section{Dra. BEATRIZ ELENA MARÍN OCHOA, beatrize.marin@upb.edu.co}

Doctora en Comunicación y Periodismo, Magíster en Comunicación y Periodismo y Máster en Comunicación y Educación de la Universidad Autónoma de Barcelona. Comunicadora Social Periodista de la UdeA. Profesora titular de la Facultad de Comunicación Social - Periodismo, Coordinadora de Investigaciones de la Escuela de Ciencias Sociales y Líder del Grupo de investigación en Comunicación Urbana, GICU, A Colciencias, de la UPB. 
Mag. FEDERICO MEDINA CANO, federico.medina@,upb.edu.co Licenciado en Filosofía y Letras de la UPB. Magíster en Literatura Latinoamericana de la Universidad de Washington. Investigador de la línea de narrativas del Grupo de Investigación en Comunicación Urbana-GICU, docente de pregrado y posgrado de la Facultad de Comunicación Social - Periodismo de la UPB.

Dr. FRANCESC MORERA VIDAL. francescmorera@gmail.com Doctor en Comunicación por la UAB, profesional del diseño gráfico (editorial, corporativo y packajing) y secretario de la junta de gobierno del Colegio Oficial de Diseño Gráfico de Cataluña (España). Experto en los aspectos técnicos de la producción gráfica y el sentido comunicativo de los enunciados visuales. Imparte y coordina asignaturas en el grado en Artes y Diseño de la Escuela Massana, adscrita a la UAB. Colabora con la UOC y con la Facultad de la Comunicación de la UAB en investigaciones sobre la efectividad de la infografía así como la determinación de unidades discretas en el lenguaje visual. En su contribución a este libro, resalta las características de la infografía: un lenguaje de síntesis idóneo en las nuevas narrativas.

WILLIAM ROBSON CORDEIRO, williamdefato@gmail.com

Doctorando en Periodismo por la Universidad Federal de Santa Catarina en Florianópolis, Brasil, con énfasis en Tecnologías, Lenguajes e Innovación en el Periodismo. Realizó estancia de investigación en la Universidad Autónoma de Barcelona bajo la supervisión del profesor José Luis Valero Sancho y financiado por Coordinación De Perfeccionamiento de Personal de Nivel Superior del gobierno brasileño. Maestría en Estudios de los Medios por la UERN. Es graduado en Comunicación Social, con habilitación en periodismo, por la UERN, donde también fue profesor. Integra el Núcleo de Estudios y Producción Hipermedios Aplicados al Periodismo NEPHI-Jor- y desarrolla investigaciones en el campo de la visualización sintética en el periodismo online, con orientación de la investigadora Raquel Ritter Longhi. 


\section{Dr. JOSÉ LUIS VALERO SANCHO, joseluis.valero@,uab.cat}

Profesor titular de la Facultad de Ciencias de la Comunicación de la $\mathrm{UAB}$, imparte asignaturas aplicadas a los medios visuales $\mathrm{y}$ audiovisuales de producción en multimedia e interactivos, diseño gráfico, dirección de arte, infografía, visualización de datos y otras materias relacionadas en asignaturas de Periodismo y Comunicación Audiovisual. Autor de varios libros sobre infografía y diseño gráfico, además de multitud de artículos publicados en revistas indexadas que se relacionan con sus investigaciones, fundamentalmente en los ámbitos de conocimiento mencionados. Miembro del Grup de Recerca GRISS de la UAB, presidente de la Sociedad Catalana de Infografía, jurado en medios impresos y on line en los Premios Internacionales de Infografía Malofiej de la Society for News Design (SND), colaborador de Andiarios-SENA (Colombia) en desarrollo de medios web periodísticos, etc.

\section{Dr. TARCÍSIO VANZIN, tvanzin@gmail.com}

Graduado en Arquitectura y Urbanismo por la UFSC (1983) y en Ingeniería Mecánica de Op. Por la UCS (1974). Máster (2001) y doctorado (2005) en Ingeniería de Producción por la UFCS. Actualmente es profesor Asociado de la UFSC y ministra disciplinas de graduación para el curso de Arquitectura y Urbanismo y para el curso de Sistemas de Información. Es profesor colaborador del programa de post-graduación en Arquitectura y Urbanismo de la UFSC y profesor permanente del programa de post-graduación en Ingeniería de Gestión del Conocimiento de la UFSC. Está ligado al Departamento de Ingeniería del Conocimiento del Centro Tecnológico de la UFSC. Tiene experiencia profesional en las áreas de Proyectos Industriales, Revisiones, Proyectos de Arquitectura y Construcción Civil. Como docente imparte, en grados, Métodos de Representación, Geometría y Diseño, con énfasis en los siguientes temas: producción hipermedia, geometría, enseñanza-aprendizaje, creatividad y Teoría General de Sistemas. En los programas de post-graduación ministra las disciplinas de Producción Hipermedia, Sistemas Multimedia, Ciberciudades, Cibersociedad, Creatividad, Errores Humanos e Historia y Teoría de los Medios. 


\section{A \\ Os autores do livro}

Dr. AITOR CASTAÑEDA ZUMETA, aitor.castaneda@ehu.eus

Doutor em Comunicação Social pela EHU. Mestre em Comunicação e licenciado em Publicidade e Relações Públicas pela EHU. Técnico superior em ilustração e artes gráficas pela Escola de Arte e Design I·D arte de Vitoria-Gasteiz (Espanha). Apresenta neste livro um estudo da infografia dos principais grupos informativos do País Vasco, região espanhola de elevada cobertura jornalística, e analisa a qualidade das infografias dos jornais desses grupos, que cobriram o atentado terrorista do 17A na cidade de Barcelona, evento de grande relevância internacional. Por outro lado, propõe um estudo sobre a infografia didática na plataforma $\mathrm{OCW}$ da EHU, na qual é professor atualmente.

\section{JORDI CATALÀ DOMÍNGUEZ, jordicatalad@gmail.com}

Comunicador visual, designer gráfico, jornalista, historiador pela UB, professor associado das universidades Autônoma de Barcelona, de Vic e Pompeu Fabra, e em los centros HEINA, Elisava e o Centro Universitário de Design de Barcelona. Ministra cursos de mestrado, pós-graduação e de formação contínua -Tecnocampus e IL3 (UB)-. Criou o Departamento de Infografia do El Periódico de Catalunya, onde foi redator-chefe de infografia, obtendo cerca de duzentos prêmios nacionais e internacionais, entre eles o de Melhor Design de Jornal da Europa (2008). Especialista em infografia de empresa, comunicação visual, criação de conteúdos visuais e visualização e redes. Foi duas vezes jurado do European Newspapers Award.

HERNÁN FRANCO HIGUITA, hernandfranco@gmail.com Designer gráfico da UPB, estudante de Mestrado em Design e Criação Interativa na Universidade de Caldas (Colômbia). Docente catedrático da UPB. 
Dra. MARIANA LAPOLLI, marilapolli@gmail.com

Mestre, Doutora e Pós-doutora em Mídias do Conhecimento pelo Programa de Pós-Graduação em Engenharia e Gestão do Conhecimento da UFSC. Realizou estágio doutoral na Facultade de Ciências da Comunicação da UAB. Especialista em "Corpo: Dança, Teatro e Performance" pelo Centro de Artes e Educação Célia Helena em São Paulo. Formada em Comunicação Social. Atua como produtora editorial, escritora e diretora de criação na Editora Pandion. É atriz e bailarina, integrante do Grupo Pesquisa Teatro Novo. Publicou livros, capítulos de livros e artigos científico nas áreas de: Cultura Visual, Narrativas, Infografia, Hipermídia, Criatividade, Corpo etc. Autora do livro INFOGRAFIA na era da cultura visual (Pandion, 2016).

\section{Dra. BEATRIZ ELENA MARÍN OCHOA,} beatrize.marin@upb.edu.co

Doutora em Comunicação e Jornalismo, Mestre em Comunicação e Jornalismo e mestre em Comunicação e Educação pela UAB. Comunicadora Social Jornalista da UdeA. Professora titular da Faculdade de Comunicação Social - Jornalismo, Coordenadora de Pesquisas da Escola de Ciências Sociais e Líder do Grupo de pesquisa em Comunicação Urbana (GICU) A Colciencias, da Universidade Pontifícia Bolivariana em Medellin.

Mag. FEDERICO MEDINA CANO, federico.medina@upb.edu.co Licenciado em Filosofia e Letras da UPB. Mestre em Literatura Latinoamericana da Universidade de Washington. Investigador da linha de narrativas do Grupo de Pesquisa em Comunicação Urbana (GICU), docente de graduação e pós-graduação da Faculdade de Comunicação Social - Jornalismo da UPB.

Dr. FRANCESC MORERA VIDAL, francescmorera@gmail.com Doutor em Comunicação pela UAB, profissional do design gráfico (editorial, corporativo e packaging) e secretário do conselho de governo do Colégio Oficial de Design Gráfico de Catalunha (Espanha). Especialista nos aspectos técnicos da produção gráfica e no sentido comunicativo dos enunciados visuais. Ensina e coordena disciplinas na graduação em Artes e Design da Escola Massana, anexa 
à UAB. Colabora com a UOC e com a Faculdade de Comunicação da $\mathrm{UAB}$ em pesquisas sobre a efetividade da infografia, assim como a determinação de unidades discretas na linguagem visual. Em sua contribuição para este livro, ressalta as características da infografia: uma linguagem de síntese ideal para as novas narrativas.

\section{WILLIAM ROBSON CORDEIRO, williamdefato@gmail.com}

Doutorando em Jornalismo pela UFSC em Florianópolis, Brasil, com ênfase em Tecnologias, Linguagens e Inovação no Jornalismo. Realizou estância de pesquisa na UAB, sob a supervisão do professor José Luís Valero Sancho e financiado pela Coordenação de Aperfeiçoamento de Pessoal de Nível Superior, do governo brasileiro. Mestrado em Estudos dos Meios pela UERN. É graduado em Comunicação Social, com habilitação em jornalismo pela UERN, onde também foi professor. Integra o Núcleo de Estudos e Produção Hipermídia Aplicados ao Jornalismo (NEPHI-Jor) - e desenvolve pesquisas no campo da visualização sintética no jornalismo online, com orientação da pesquisadora Raquel Ritter Longhi.

\section{Dr. JOSÉ LUIS VALERO SANCHO, joseluis.valero@,uab.cat}

Professor titular da Faculdade de Ciências da Comunicação da $\mathrm{UAB}$, misma disciplinas aplicadas aos meios visuais e audiovisuais de produção em multimídia e interativos, design gráfico, direção de arte, infografia, visualização de dados e outras matérias relacionadas em classes de Jornalismo e Comunicação Audiovisual. Autor de vários livros sobre infografia e design gráfico, além de diversos artigos publicados em revistas indexadas relacionadas às suas pesquisas, fundamentalmente nos âmbitos de conhecimento mencionados. Membro do Grup de Recerca GRISS da UAB, presidente da Sociedade Catalana de Infografia, jurado em meios impressos e on-line nos Prêmios Internacionais de Infografia Malofiej da Society for News Design (SND), colaborador de Andiarios-SENA (Colômbia) em desenvolvimento de meios web jornalísticos etc.

\section{Dr. TARCÍSIO VANCIN, tvanzin@gmail.com}

Possui graduação em Arquitetura e Urbanismo pela UFSC, graduação em Engenharia Mecânica de Op. pela UCS, mestrado e doutorado em Engenharia de Produção pela UFSC. Atualmente é professor 
Associado da UFSC e ministra disciplinas na graduação para o curso de Arquitetura e Urbanismo e o para o curso de Sistemas de Informação. É professor colaborador no Programa de Pós Graduação em Arquitetura e Urbanismo e professor permanente do programa de Pós-Graduação em Engenharia e Gestão do Conhecimento da UFSC. Está lotado no Departamento de Engenharia do Conhecimento do Centro Tecnológico da UFSC. Tem experiência profissional nas áreas de Projetos industriais, Avaliações, Projetos de Arquitetura e Construção Civil. Como docente atua, na graduação, em Métodos de Representação, Geometria e Design, com ênfase nos seguintes temas: Produção Hipermídia, Geometria, Ensino-aprendizagem, Criatividade e Teoria Geral de Sistemas. Nos programas de pós-graduação ministra as disciplinas de Produção Hipermídia, Sistemas Multimídia, Cibercidades, Cibersociedade, Criatividade, Erros Humanos e Historia e Teoria da Mídia. 